\title{
"It's a... does it matter?" Theorising "boy or girl" binary classifications, intersexuality and medical practice in New Zealand
}

\section{Geraldine Christmas}

\begin{abstract}
A thesis
submitted to the Victoria University of Wellington in fulfilment of the requirements for the degree of Doctor of Philosophy
\end{abstract}

Victoria University of Wellington 



\section{Abstract}

This thesis investigates the clinical management of intersexuality in New Zealand and support for intersex New Zealanders and their families. My research is informed by the narratives of New Zealanders with intersex conditions, parents of children with intersex conditions, registered nurses, specialist clinicians, representatives from community/support organisations and a former member of parliament. This thesis also investigates medical teaching in New Zealand: not only about intersex anatomy but two key issues which shape society - gender and sexuality. Feminist, postmodern and queer theorising about these issues also inform this thesis in relation to traditional assumptions about gender and sexuality, and medical recommendations for sex assignment and rearing. Historical accounts of societal attitudes and medical thinking towards sex classification, sexuality and intersexuality also inform this thesis.

Despite New Zealand's reputation as an egalitarian democracy, my findings show that judgemental attitudes towards difference still exist in parts of New Zealand society. This is discussed with reference to poststructuralist and oral history theorising about societal power structures and research on sensitive topics. Undertaking research in New Zealand, on what can be regarded as a sensitive topic, can be difficult in terms of maintaining confidentiality in a small population.

The implications of practising medicine in New Zealand are highlighted as, due to its smaller population, the number of intersex individuals coming to clinicians' attention is small compared to some other countries. From my findings, it appears that specialist clinicians and medical schools in New Zealand rely on medical models from other countries with larger populations, which have a greater number of babies born with intersex conditions and consequently more specialised medical practice and education. The narratives of intersex people and their parents also highlight the implications of living in a smaller population. This is not only with regard to medical experiences (such as hospitals which often have little experience of intersex issues), but also societal prejudices and judgements towards lesser known variations of sexual anatomy. 


\section{Acknowledgements}

Firstly, I am grateful to my supervisors Dr Alison Laurie and Dr Lesley Hall, of the Gender and Women's Studies department at Victoria University of Wellington (VUW), for their expert supervision and guidance. Without them I would not have successfully completed this thesis. I also wish to thank Dr Sue Cornforth, at the Faculty of Education, VUW, and Professor Charles Daugherty, Assistant Vice-Chancellor (Research), VUW, for their guidance, support and encouragement.

I am also grateful to Dr Kathy Nelson at the Graduate School of Nursing, Midwifery and Health, VUW, for her invaluable advice and feedback on preparing my ethics application. Dr Carmen Dalli at the Department of Early Childhood Studies, VUW, who searched her files and provided me with papers by Dr John Money from his visit to VUW in the 1980s. She also kindly let me spend an afternoon in her office so I could read through and photocopy Money's papers. I thank Sheila Law at the Faculty of Education, VUW, for her much-appreciated help and support. Sue Kelly at the Postgraduate Students' Association (PGSA), VUW, kindly provided me with a key to a quiet office space at the university's Kelburn Campus, which greatly assisted my study.

Staff at the Wellington Medical School Library - notably Janine Faulknor, Maxine Schutte and Stephanie Houpt, who allowed me access to journals and books (some centuries old) from the library's historical collection, and helped me undertake searches on library databases. Lynette Shum at the Oral History Centre (OHC) of the Alexander Turnbull Library (part of the National Library of New Zealand) instructed me on how to use a digital recorder, and booked digital recorders for my field trips. Linda Evans of the OHC archived copies of some recorded interviews (as requested by participants) and also booked digital recorders.

Mani Mitchell, Executive Director of the Intersex Trust Aotearoa New Zealand (ITANZ), lent me DVD copies of television documentaries and current affairs reports on intersex matters, and e-mailed me encouragement and support. Sue Russ, Senior Policy Analyst of the Ministry of Social Development, lent me a DVD copy of the San Francisco Human Rights Commission televised hearing (2004) on the medical 
management of intersex people. Jack Byrne, Senior Policy Analyst at the Human Rights Commission, Elizabeth Kerekere, Chair of Tiwhanawhana Trust and Joanne Neilson, President (2008-2010) of Agender New Zealand, for their help, time and advice on research matters. My manager, Damien Grant, at my day job at the NZ Transport Agency, supported me in having time off to undertake fieldwork, meet with my supervisors and complete this thesis.

I am especially grateful to Sarah (see List of participants chapter), who enabled access to some participants, her words of encouragement in e-mails, and her hospitality when I undertook fieldwork in her region. Finally, I am forever grateful to the participants who invited me into their homes and workplaces, and shared their insights and views with me. 



\section{Contents}

Abstract

Acknowledgements

$1 \quad$ Introduction 1

My personal standpoint $\quad 1$

The key issues and questions $\quad 2$

What's different about New Zealand? 3

What this thesis aims to bring to the body of knowledge 5

Definition of terms 6

How this thesis is structured 9

\section{PART ONE: SETTING THE SCENE - THE PAST AND PRESENT}

$2 \quad$ Feminism, gender and "questionable" bodies - what's already been said? 13

The 19th century - the origins of "women's problems" 13

The colonial "gaze" (and abhorrence) 16

Second wave feminism - "women's problems" questioned 18

Medical power and status - "the expert" 22

The medical "gaze" 28

Clinicians and the management of intersexuality 29

Academic perspectives on intersexuality and medical institutions 32

3 The Romans, the Church and the 19th century: "evil" and "curious" bodies 39

Early civilisations $\quad 39$

The founding of Rome $\quad 41$

The medieval period $\quad 42$

The 16th century - Ambrose Paré 43

The 19th century - dissections, discoveries and "interesting cases" 46

4 The 20th century: natural variations and "nature versus nurture" 54

Magnus Hirschfeld and the case of Lili Elbe 55

Hugh Young and the development of urology $\quad 57$

John Money and the implementation of "gender policy" 60

"Nature versus nurture" and "the twins case" 66

$5 \quad$ The scientific basis of sexual differentiation $\quad 72$

Typical sexual development $\quad 72$

Differences of sexual development (DSDs) 76

Disrupted development of the primordial gonad 77

$\begin{array}{ll}\text { Gonadal dysgenesis } & 78\end{array}$

Male pseudohermaphroditism - incomplete masculinisation of a
$\quad$ genetic $(46, X Y)$ male

Female pseudohermaphroditism - virilisation of a genetic (46,XX) female 86 


\section{PART TWO: PERSPECTIVES ON SEX, GENDER AND INTERSEX}

$6 \quad$ Theoretical approaches to sex and gender $\quad 89$

Second wave feminism - Greer, Millett and Firestone $\quad 89$

Biological determinism 99

"Brain sex" 95

Third wave feminism 96

Feminist poststructuralist theory 98

Postmodern feminist theory $\quad 99$

Queer theory 103

7 People's first hand experiences - what's already out there? 107

Experiences in New Zealand 107

Experiences in other countries 111

The right to choose one's gender 117

The desire for intersex embodiment $\quad 120$

\section{PART THREE: RESEARCH FINDINGS AND MEDICAL PRACTICE}

$8 \quad$ Methodologies and methods 123

Theorising oral history $\quad 124$

Research on sensitive topics 126

Maintaining confidentiality in New Zealand 129

Feminist research methodology - ethics, dilemmas and principles $\quad 131$

Queer methodology 133

Lectures and tutorials at tertiary institutes 134

Specialist clinicians and registered nurses 135

Community/support organisations 136

Methods 139

9 Medical practice and management 143

The first question: "Is it a boy or a girl?" 143

Sex assignment 148

Surgery and hormone administration $\quad 152$

Support-peer and social issues $\quad 162$

10 Parents' experiences with "experts", hierarchies and empowerment 167

When parents received their child's diagnosis 167

Parents' experiences with medical professionals 172

11 People's experiences and understandings about surgery and gender 183

Experiences with surgery 183

Gender - "How would you describe yourself?" 195

12 Education and awareness - different approaches to sexual differences 202

"Reproduction and Endocrinology" lectures - Auckland Medical School 202

Paediatric surgery seminars - Christchurch School of Medicine 204

Mr Chris McEwan-plastic surgeon 207

"Identity and Diversity" lecture - midwifery programme 210 
Registered nurses

13 Conclusions and recommendations

Reflections on my research

Medical rationales, health concerns, gender and sexuality

Narrators' understandings about clinical procedures and gender

Support and acceptance in New Zealand

My findings, issues and theoretical positions

Recommendations

Future research

Finally...

List of participants

Glossary of frequently used terms

Appendix I: Approval letter from the Multi-region Ethics Committee

Appendix III: Sample e-mail to support organisations

Appendix IV: Sample Consent Form for clinicians

References 
You know that you were a boy, or that you were a girl, long before you learned to read.

- John Money and Patricia Tucker, in Sexual Signatures (1975, p. 3). 


\section{Chapter 1: Introduction}

"Do you know what intersexuality is?"

Most people in New Zealand who asked about my research know little about intersexuality, so I would briefly explain what this biological variation is. My explanation was met with comments ranging from "that must be fascinating" to "ugh what do you want to do that for?!"

The latter comment shows that some parts of society feel uncomfortable about bodies with both male and female characteristics, which is one aspect that this thesis discusses. This discomfort may be because some people are familiar only with the categories of male and female, which this thesis also critiques. Specifically, this thesis examines the clinical management of intersexuality in New Zealand, in relation to theorising about binary sex classification (male or female) and gender. I also examine this topic from recorded interviews and personal communications with intersex people, parents of children with $\mathrm{CAH}$, and various professionals involved in intersex issues in New Zealand.

\section{My personal standpoint}

My personal standpoint on this subject arises from my long interest in feminist and gender issues, particularly with regard to clinicians' recommendations for sex assignment and rearing. Though I do not have an intersex condition, nor did I have traumatic experiences of medical institutions like some intersex people (see chapter 7) and David Reimer (see chapter 4), their childhood experiences of gender and sex role expectations - because of their female assignment - resembled some of mine. I was a tomboy throughout my childhood and early adolescence. Despite my declared sex as "girl" by the obstetrician who delivered me at Lower Hutt Hospital, New Zealand, my parents gave me the freedom to pursue my own interests and activities. In childhood make-believe games, mostly with boys but occasionally with other girls, I would always play male roles - I was never Batgirl but Batman. 
Reimer's recollection of being "miserable" in Girl Scouts (when he was named Brenda), with stereotypically feminine activities such as making daisy chains while his brother Brian did "fun stuff” in Cubs (Colapinto, 2000, p. 58), brought back memories of my short stint in Brownies. I remember not enjoying domestic-related activities such as learning how to set tables, and wished that we could do more adventurous activities as my brother did in Cubs. Though the other Brownies were welcoming and pleasant towards me, I distinctly remember feeling out of place because of an inner sense that was more masculine than feminine. Many years later I would read about this sense as gender fluidity (Cox et al., 1997, p. 178). Reimer's peer issues at school because of "look[ing] like a boy" (Colapinto, 2000, pp. 124-125) also brought back a memory of primary school. A girl, who was not teasing me but being serious, approached me and asked hesitantly, "Hey, are you a boy who has to be a girl?"

From my experiences, I agree with Cox et al.'s argument that fluidity can occur between gender and sex anatomy (Cox et al., 1997, p. 178). I therefore question medical recommendations for rearing based on sex anatomy, which imply that children because of their assignment as male or female - should be treated differently. In turn, I agree with Ana Marie Cox's assertion that "gender is inessential" (Cox; in ibid., p. 191). My childhood experiences have also shaped my argument that medical recommendations for sex assignment, based on anatomical traits such as gonads, appear to follow biological determinist theories: claims that boys are "naturally" aggressive and competitive (Fausto-Sterling, 1985, pp. 123-124) and better suited to rough physical sports such as rugby, while girls are "naturally" nurturing (Hyde, 2005, p. 590) and prefer playing with dolls. Indeed, if such claims were true I would have been pleased to receive a doll I was given one Christmas when I was four or five, and would not be riding my mountain bike along dirt tracks and getting sprayed in mud - as I regularly do now.

\section{The key issues and questions}

Gender and sex role stereotypes are key issues discussed in this thesis with regard to clinicians' recommendations for male or female sex assignment and rearing. This thesis discusses medical rationales for establishing the child's sex assignment as quickly as 
possible when a baby is born with ambiguous genitalia - when clinicians cannot immediately announce if the child is male or female. A common medical paradigm appears to be that clinicians recommend a male or female assignment, and rearing as male or female, in accordance with a child's sex anatomy. Clinicians' advice on procedures to "correct" a child's ambiguous anatomy appears to reflect John Money's belief that unambiguous genital appearance is essential for children to successfully function socially and sexually as adults.

My research questions below form the basis of my arguments, analysis and conclusions:

- What are medical rationales for managing intersex conditions with regard to health concerns, and how do traditional assumptions about gender and sexuality relate to medical decision-making?

- What are the understandings of intersex people, parents, clinicians, nurses and community/support organisation representatives in New Zealand about clinical procedures and gender?

- What are narrators' understandings of support and acceptance of intersexuality in New Zealand, especially with its small population and apparent connectedness?

- What are the links between my findings, and feminist and gender theories?

A key concern in this thesis is the issue of human rights, with regard to the right to choose one's own gender and anatomy, as some intersex people (see chapter 7) have publicly lamented that they were denied this choice.

\section{What's different about New Zealand?}

A significant difference about New Zealand is its small population $(4,440,308)^{1}$ compared to countries such as Australia $(22,717,410),{ }^{2}$ Canada $(34,755,634),{ }^{3}$ the United Kingdom (62.3 million) ${ }^{4}$ and the United States of America $(314,283,631){ }^{5}$ Our

\footnotetext{
${ }^{1}$ Statistics New Zealand website (www.stats.govt.nz), accessed on 2 September 2012.

${ }^{2}$ Australian Bureau of Statistics (www.abs.gov.au), accessed on 2 September 2012.

${ }^{3}$ Statistics Canada website (www.statcan.gc.ca), accessed on 2 September 2012.

${ }^{4}$ Office for National Statistics, UK (http://www.ons.gov.uk/ons/taxonomy/index.html?nscl=Population), accessed on 2 September 2012.

${ }^{5}$ United States Census Bureau (www.census.gov), accessed on 2 September 2012.
} 
small population can be problematic in terms of confidentiality (see chapter 8), as there often appears to be a connection amongst New Zealanders. A sobering example of this connectedness was when my mother, while I was growing up, joined an adult community education class in painting: one of the class members was the sister-in-law of internationally-renowned sexologist Dr John Money (1921-2006). Indeed, when I lived in London (UK) one aspect I loved was being completely anonymous while walking around in public places - and never encountering anyone I knew!

Because of New Zealand's small population, the number of babies born with intersex conditions per year is small compared to other countries. In other countries there are some intersex conditions which have a higher incidence amongst ethnicities such as Yupik Eskimos and Moroccan Jews (Blackless, Charuvastra... \& Lee, 2000, p. 156). However, present research does not indicate whether the incidence of intersex conditions in New Zealand is higher than elsewhere. The Ministry of Youth Development states that " $[\mathrm{t}]$ here is no reliable data on the number of intersex or transgender young people in New Zealand" (Ministry of Youth Development, 2013). A paper by Statistics New Zealand also states that, while "[s]ocial policy and human rights discussion often includes transgender and intersex population[s]", these populations are not included in their paper as "the transgender and intersex populations are assumed to be very small with information gathering about these topics still in its infancy" (Statistics New Zealand, 2008, p. 6). Consequently, the Human Rights Commission invited submissions to Statistics New Zealand regarding the latter's Sex Classification Standard (Human Rights Commission - hereafter HRC, 2010). However, the Human Rights Commission asserts that currently " $[\mathrm{t}]$ here is no systematic identification of data gaps, nor a framework for data collation and analysis" (ibid.).

The smaller number of babies with intersex conditions can be problematic for clinicians in New Zealand who may have never encountered a child with an intersex condition, and therefore have little experience or awareness of intersexuality (see chapter 10). New Zealand's smaller number of intersex cases also has implications for New Zealand paediatric/urological surgeons, compared to such surgeons at American hospitals who may encounter intersex cases more frequently. Consequently New Zealand children are commonly referred to Royal Children's Hospital in Melbourne, in our neighbouring 
country Australia, which is regarded amongst the New Zealand medical community as a centre of excellence (see chapter 9).

Takatāpui (NZ Maori = intimate companion of the same sex, discussed in chapter 2) and fa' afafine (Samoan = way of the woman $)$ are indigenous cultural identities of gender fluidity in New Zealand, which contrast with Eurocentric views that one's inner sense of being male or female aligns with one's sex anatomy. While the latter originates from Samoa, fa'afafine communities have a particularly strong presence in Auckland which has a high Pacific population. Georgina Beyer, who made history as the world's first elected transgender mayor and later a member of the New Zealand Parliament, remarks that legal equality for gay, lesbian, bisexual, transgender and intersex (GLBTI) communities is very advanced in New Zealand whereas other countries "are about 25 years behind" (Beyer, 2010, interview). Indeed, during a group discussion at a conference I attended, an American transwoman said that New Zealand was "lightyears" ahead of her country in terms of acceptance.

However, universal amongst intersex people in New Zealand and other countries are the human rights issues of acceptance, dignity and informed consent. As in Australia, Canada, the UK and USA (see chapter 7), intersex people in New Zealand talk about experiences of "secrecy and shame", and undergoing medical procedures during childhood over which they had no control (HRC, 2007, pp. 80-81).

\section{What this thesis aims to bring to the body of knowledge}

This thesis examines the medical and social implications of intersexuality in New Zealand, a country with a small population. Maintaining confidentiality in a small population is discussed with regard to recording the narratives of New Zealanders with intersex conditions who, unlike publicly intersex activist Mani Mitchell, did not want their identities revealed. The implications of this for specialist medical management are also discussed. As a consequence of a smaller number of intersex births compared to countries with larger populations, some clinicians in New Zealand are likely to have little experience of intersex conditions, which in turn has implications for parents who want the best possible care and support for their children. As well as parents' 
viewpoints about their children's intersex conditions and hospitals in New Zealand, this thesis includes the viewpoints of specialist clinicians and registered nurses about the medical management of intersexuality in New Zealand - and the implications of its smaller population. Intersexuality is a lesser-known condition in New Zealand compared to Down syndrome, for example.

While New Zealand boasts about being an accepting, egalitarian society, prejudices and judgements towards a little-known condition still surface. New Zealand's connectedness thus has implications for some parents who want to protect their children from stigmatisation and gossip, not only because of intersexuality's "circus freak" connotations (ibid., p. 81), but also because of the ingrained societal assumption that people can only be classified as male or female. In particular, the fear of being found out has implications for bringing new knowledge to what is an under-researched topic in New Zealand. This relates to a theoretical perspective on oral history: undertaking research on what can be considered a sensitive topic may pose a "threat" to participants, as the information collected may stigmatise participants (Lee, 1993, p. 4; in DicksonSwift, James \& Lamputtong, 2008, p. 2).

While intersex people's experiences with medical institutions have been widely published (see chapter 7), this thesis is a study with a specific New Zealand focus. My research presents findings about educational institutions and community/support organisations in New Zealand, and discusses differences in teaching about sex, gender and intersexuality to health professionals and others in New Zealand.

\section{Definition of terms}

This section defines the key terms that this thesis is concerned with, in relation to medical and social settings. Intersexuality is a biological variation, in which an individual with an intersex condition is often born with ambiguous genitalia which do not appear typically male or female. Individuals are also born with either a combination of male and female internal sex organs (as with true hermaphrodites), or internal sex organs which are discordant with their external genitalia (as with male and female 
pseudohermaphrodites). Specific intersex conditions are described in detail in chapter 5.

Sex refers to an individual's classification as male or female, based on anatomical differences such as testes and uteruses respectively (Connell, 2009, p. 51). A common view is that human beings, like many other species, are "dimorphic": the view that human bodies only exist in two forms - male and female (ibid.). Anne Fausto-Sterling, however, argues that two sexes "are not enough" (Fausto-Sterling, 1993, p. 20) when considering occurrences of intersexuality - "as many as 4 percent of births" (ibid., p. 21). She therefore proposes that individuals be classified in at least five sexes: males, females, "herms" (for true hermaphrodites), "merms" (for male hermaphrodites) and "ferms" (for female hermaphrodites (ibid., p. 21). Sexuality can be described as a social construction of the expression of desire (Cranny-Francis et al., 2003, p. 9). A Western societal notion of female sexuality is that it is "passive", whereas male sexuality is perceived as "naturally aggressive" (ibid., p. 7). Feminists such as Adrienne Rich have also questioned the "naturalness" of heterosexuality ("compulsory heterosexuality"): the entrenched assumption that "normal" sexual intercourse involves a penis penetrating a vagina (ibid., p. 8).

Sex role is concerned with social expectations of people's behaviour, based on the notions of masculinity and femininity (Connell, 2009, p. 58) - expectations of "being a man" (Jefferson, 2009, p. 216), for example. Sex roles are also based on beliefs about biological differences: for example, that "natural aggressiveness" in boys makes them best suited to football and a military career (ibid., p. 59). While an individual's sex classification is based on reproductive anatomy, gender can be defined as "the cultural or social construction of sex" (Cranny-Francis et al., 2003, p. 3). Gender is also concerned with meanings about masculinity and femininity, in which a society organises sets of meanings about these notions and "matches" them with male or female bodies (ibid.). For instance, one view about gender is that a female body "produces feminine behaviours" and a "feminine identity" (ibid.).

Gender roles are therefore cultural expectations of "appropriate" behaviour as a male or female, while gender identity is an individual's sense of self as male or female (Kessler, 
2001, p. 162). Gender stereotypes are generalisations about men and women. An example is the generalisation that all women, based on them having a uterus, are "naturally nurturing" and have "a natural predisposition towards children" (CrannyFrancis et al., 2003, p. 143). World War II is a period regarded as having destabilised gender stereotypes about women's "natural capabilities" for certain occupations, as traditionally male occupations (such as manual work in munitions factories) became vacant when men were drafted into military forces (ibid., p. 144). However, when the war ended men wanted to return to their former occupations: propaganda used the gender stereotype of "the nurturing mother" and "the happy housewife" to encourage women to leave the workforce (ibid., pp. 144-145). In New Zealand the sport of rugby is synonymous with the New Zealand male stereotype as it is associated with “toughness, endurance and physical daring” (Du Plessis, 1994, p. 109). Rugby has also traditionally excluded women whose expected role in the "rugby family" echoes a stereotype of domesticity, via the washing of dirty rugby gear and bringing "the plate" at rugby club social functions (ibid., p. 110). "Bring a plate" (meaning to provide a plate with food on it) is still a common phrase in New Zealand vocabulary when one is invited to a social function, and was traditionally a woman's expected task. The traditional (stereotypical) phrase "ladies a plate please" can still be heard amongst older generations of New Zealanders, particularly in small rural towns.

Sex role stereotypes are ideas about "appropriate behaviour" for men and women (Lowe, 1982, p. 91) based on anatomical differences (ibid., p. 94). Marion Lowe argues that, as American men are on average taller, more muscular and have a greater bone density than women (ibid., p. 93), this has created the assumption that women cannot do activities that require strength (ibid., p. 92). She argues that such stereotypes have affected women's participation in particular sporting and athletic activities, and occupations such as construction work (ibid., p. 92). She further argues that sex role stereotypes can literally affect people's anatomy (ibid., p. 91) as differences in rearing and treatment between boys and girls can affect their growth (ibid., p. 99). A study of young female competitive swimmers revealed that "their growth, particularly during training, was more accelerated than "established norms" (ibid., p. 99). Stereotypes also maintain power structures in societies in that they create binary notions of 
"normal"/"deviant", "normal"/“pathological" and "acceptable"/“unacceptable" (Hall, 1996a, p. 258; in Cranny-Francis, 2003, p. 141).

Esther Rothblum and Violet Franks define sex role stereotypes as not descriptions of actual differences between men and women, but on what society thinks are differences between men and women (Rothblum \& Franks, 1983, p. 4). They argue that sex role stereotypes can have detrimental effects on people's mental health: for example, a woman who is not appointed to a position with opportunities because a manager assumes that women are not ambitious, and a boy whose parents discourage him from becoming emotional or upset because they believe that "boys don't cry" (ibid., p. 5).

\section{How this thesis is structured}

Chapter 2 sets the stage about injustices based on sex classification from feminist perspectives, in relation to incidents in medical history and human rights issues. This chapter discusses the medical construction of women's ailments during the 19th century, and the effects of colonisation on non-European, non-heterosexual and fluid gendered communities. This chapter then discusses medical power in relation to status, and a common societal notion that the doctor always knows best. The medicalisation of differing bodies, and academic perspectives on this, is also discussed.

Chapter 3 outlines historical shifts in thinking towards intersexuality. This thesis discusses that in early civilisations people with intersex conditions were accepted and acknowledged, whereas the founding of the Roman Empire and the establishment of the Christian Church initiated negative attitudes towards ambiguous anatomy. Chapter 3 also discusses a shift in medical thinking during the 19th century when, along with advances in surgery and science, clinicians became more fascinated with intersex bodies.

Chapter 4 discusses differing attitudes towards intersexuality from three notable 20th century figures: pioneering sexologist Magnus Hirschfeld (with regard to the case of Lili Elbe), pioneering urologist Hugh Young, and John Money. This thesis argues that, while Hirschfeld and Young appeared to hold open-minded attitudes towards gender 
fluidity and intersex anatomy, Money's work (which includes the well-known "twins case") has had a profound influence on the clinical management of intersexuality. Money used his experiment with the Reimer twins to prove his nurture over nature argument: that a twin boy who lost his penis had been, he claimed, successfully reassigned and reared as a girl. Drawing from this case Money managed to convince many clinicians that surgeries and rearing, based on his own gender theory, was the best mode of management for intersex children.

Chapter 5 is a chiefly descriptive chapter in that it defines and outlines the scientific basis of specific intersex conditions. It begins with an outline of typical sexual development, beginning from when an ovary releases a cell in the fallopian tube through to the 14 th week of the developing foetus. This chapter will include discussion of clinicians' advice about recommending a male or female sex assignment, and provide an analysis of some of these findings with regard to theoretical and intersex people's perspectives discussed in chapters 6 and 7 respectively.

In chapter 6 I will discuss various feminist theories of sex and gender which have informed arguments and analyses in this thesis. Sex classification is discussed from various theoretical perspectives - particularly female sex classification in terms of unfairness and discrimination. This chapter also discusses more recent perspectives about both sex and gender, such as third wave feminism and strands such as postmodernism. As well as discrimination based on sex classification, this thesis discusses recent theoretical perspectives of embodiment and identity beyond the male/female binary code: postmodernism argues that gender is a fluid entity, while queer theory argues for the right to blur physical boundaries of male and female forms. This thesis also discusses why second wave perspectives are relevant today - in particular, recent arguments about biological determinism and "brain sex" (Connell, 2009, p. 50).

Chapter 7 discusses published experiences from intersex people while paying close attention to theoretical perspectives in the previous chapter. The issue of trauma is a key issue with regard to intersex people's experiences of undergoing procedures during childhood - often with no explanation of why they were in hospital. Like David Reimer 
(in chapter 4), gender rights issues will be discussed with regard to Tony Briffa's opinion about an enforced stereotypically female upbringing which he rejected (Bragge, 2005).

Chapter 8 sets the scene for my field work. This chapter not only outlines methodological perspectives (oral history and queer theory) about undertaking research ethically, but the reasons for my research methods. I will also discuss difficulties I encountered in finding participants. This is with regard to the implications of undertaking research in New Zealand as its small population raises specific issues relating to confidentiality - particularly on a topic that could be considered sensitive. Drawing from both oral narratives and publications, chapter 9 outlines how intersex conditions are currently managed in New Zealand and in other countries. As well as providing health professionals' perspectives, this chapter also examines parents' and intersex people's understandings about intersex conditions and medical procedures.

In chapter 10 I discuss the experiences and feelings of parents I interviewed about their children's intersex condition. The first part of this chapter examines parents' feelings when their child's sex assignment was questioned and one parent's feelings when her son became seriously ill. Medical power is also discussed with regard to parents' interactions with clinicians - and times when some parents felt empowered to question and stand up to clinicians. In chapter 11 I examine my intersex narrators' understandings about procedures and gender, some of which contrast with intersex people's published accounts in chapter 7. Some narrators in chapter 11 also highlight the implications of New Zealand's small population in terms of specialist medical experience and support.

Chapter 12 outlines different educational approaches to intersexuality in New Zealand. It discusses what medical and midwifery students are taught, from lectures and seminars I attended. This chapter also outlines specialist clinicians' and registered nurses' experiences of their own medical education, and their viewpoints about intersexuality and gender. It then examines the work of a prominent community/support organisation and a former member of parliament with regard to the visibility and rights of intersex and diversely gendered communities in New Zealand. 
Conclusions and recommendations are based on my findings, and are outlined in the final chapter. I will reflect on my research and discuss findings in relation to my research questions. I will then suggest new strategies for medical education and practice, and what future research should be undertaken in New Zealand. 


\section{Chapter 2: \\ Feminism, gender and "questionable" bodies - what's already been said?}

This chapter sets the scene on how thinking developed about injustices based on sex classification, gender and sexuality. I will examine gender and medicine from three perspectives: feminist, current clinicians and academics.

From feminist perspectives I will first discuss 19th century medical rationales for particular procedures performed on women and imperialism: bodies considered curiosities because they fell outside Eurocentric forms. Next, I will discuss the rise of the women's health movement during the 1970s with regard to feminist concerns about women's autonomy and empowerment. The next two sections will examine medicine's potent power and influence, especially with regard to bodies considered "different". From clinicians' perspectives I will discuss recent medical rationales for managing intersex conditions, as well as societal attitudes towards ambiguity and sexuality. From the perspectives of particular academics (whose research interests focus on feminism, gender and intersexuality) I will discuss medical rationales in relation to societal constructions of male and female categories.

\section{The 19th century - the origins of "women's problems"}

This section outlines the development of thinking about injustices based on sex classification, which causes an individual to experience unfair treatment compared to others classified as male. I will first outline the origins of so-called female ailments and disorders which feminists argue were created by clinicians to keep women in their place. Such ailments, feminists argue, were based on societal expectations more than genuine health concerns such as cervical cancer which will be discussed at the end of this section. Though I have drawn from historical feminist sources mainly from the 1970s and 1980s, I will discuss their relevance to current medical rationale for managing intersexuality.

Feminist theorists Barbara Ehrenreich and Deirdre English argue that American clinicians during the 19th century encouraged upper-middle class women to be "sick" 
(Ehrenreich \& English, 1978, pp. 43, 52). Clinicians developed medical theories which supported societal expectations of women and these claims were easily believed during a time when human anatomy was not clearly understood (ibid., p. 43). Ehrenreich and English comment that a motive behind these theories was to increase and ensure uppermiddle class women's dependence on men financially - hence an upper-middle class woman would be restricted to a "kept woman" (ibid., p. 52). Ehrenreich and English report on two key aspects of medical theory: "conservation of energy" which proposed that only one organ could develop in that energy was drawn away at the cost of other organs, and that a woman's reproductive organs controlled "the whole woman" (ibid., p. 44). Clinicians thus advised women and men to conserve their energy in different ways (ibid., p. 44). As upper-middle to upper class men were the "doers" they were warned not to "spend their seed" ("the essence of their energy") wastefully, which would result in "debilitated sperm" and hence risk fathering "runts", "feeble" babies and female children (ibid., p. 44). On the other hand, as women were the "breeders" they were advised to conserve energy towards their uteri (ibid., p. 45). Ehrenreich and English report that when women menstruated, were pregnant or even reached menopause, clinicians advised long periods of bed rest (ibid., p. 45). Clinicians then claimed that higher education could seriously endanger a woman's health as overdevelopment of the brain, they warned, "would atrophy the uterus" (ibid., p. 45).

Because clinicians often held God-like positions of power, many people regarded what they said as gospel. Ehrenreich's and English's accounts of what occurred during the 19th century show how oppressive stereotypes originated from societal beliefs: for example, the notion that women should not seek careers as their supposed role is to become a mother. This stereotype was advocated in New Zealand by Dr Frederick Truby King, a Dunedin clinician who founded the Royal New Zealand Plunket Society in 1907, who warned that girls who "worked too hard at school" would not "develop properly" and would be later "incapable of breastfeeding" (King, 1906; in Kedgley, 1996, p. 41). Truby King believed that girls should be educated in "domesticity" instead, not only to "benefit" women but "the race" as well (ibid., p. 41), and his beliefs were consistent with eugenic concerns about the European population's low birthrate in New Zealand - considered a threat to the British Empire (ibid., p. 40). Indeed, Auckland clinician Dr Herbert Barraclough, who remarked that "[o]nly savages increase 
without stint" (Barraclough; in ibid., p. 40), regarded women as "breeders for the empire" and even launched a campaign to prevent women from working (ibid., p. 39).

Another 19th century clinical belief was that the ovaries influenced women's minds: character traits such as irritability and "bad habits and attitudes" were symptoms of diseased ovaries (Ehrenreich \& English, 1978, p. 47). While masturbation was regarded as a "vicious" trait in both men and women that caused physical damage, clinicians were particularly concerned about female masturbation - a form of "hypersexuality" (ibid., p. 47) - that could cause grave illnesses such as tuberculosis (ibid., p. 47). A source of supposed evidence was the high rate of tuberculosis amongst prostitutes, which strengthened the belief that women's sexual desires were abnormal as they were dangerous to their health (ibid., p. 47). Health publications advised women that it was important to develop feminine traits such as maternal instincts to prepare them for their expected role of reproduction, while sexual desire (lust) was considered to be a normal trait in men (ibid., p. 47). It could be argued that these health publications were a contributing precedent to current medical rationale for sex assignment because of biological factors such as a uterus, based on stereotypical notions that women reproduce. The very words "rearing as female" appear to imply that female-assigned children should be treated differently from a male-assigned child. It could also be argued that these health publications, with their advice about developing feminine traits, may have been a contributing factor to gender stereotypes. Indeed, female-assigned children (intersex or not) are often given dolls which reinforce the nurturing female stereotype, as highlighted by Tony Briffa's account (see chapter 7) and Natasha Walter's argument that stereotypical expectations of children are as prevalent as ever (Cochrane, 2010).

One procedure undertaken by clinicians to suppress female sexual appetite, which in women was regarded as a mental disorder, was a clitorodectomy (surgical removal of the clitoris) (Barker-Benfield, 1978, p. 23). The procedure, invented by English gynaecologist Isaac Baker-Brown in 1858, was first performed in the USA in the late 1860s (ibid., p. 23). Ehrenreich and English report that a medical text of this period stated that "[u]nnatural growth of the clitoris" was "likely to lead to immorality" (Ehrenreich \& English, 1978, p. 50), and while many clinicians disagreed with this 
procedure, they were likely to recommend it for cases of nymphomania (ibid., pp. 5051). Another common procedure performed in the USA from 1860 to 1890 was "female castration" (removal of the ovaries) as a cure for "unruly behaviour" (ibid., p. 51). After the procedure women were noted by clinicians to be "orderly" (ibid., p. 51). Ehrenreich and English remark that the mere threat of surgery by women's husbands - who often brought them to clinicians - probably caused women to become more passive (ibid., p. $51)$.

Clitorodectomies also occurred in 19th century New Zealand, as highlighted by the case of Annemarie Anon (b. c1869) who in 1890 underwent a clitorodectomy and removal of her ovaries and fallopian tubes in a cottage by Seacliff Railway Station, Otago (Brookes, 1991, pp. 15-16). The procedure was performed by Dr Ferdinand Batchelor who was assisted by Truby King and two other clinicians (ibid., pp. 15-16). Previously Annemarie's family had been concerned about her "raving" behaviour and later "profound melancholy" and "dull" temperament (ibid., p. 15). A local clinician suggested that she be "completely unsexed" as masturbation was considered to be the cause of her "odd" temperament (ibid., p. 15). Indeed, 19th century clinicians attributed women's "insanity" ("hysteria") to diseases of their reproductive organs (Potts, 2002, pp. 21-22).

Current medical rationales for clitoral reduction surgeries on intersex children appear to resemble historical claims that enlarged clitorises are unnatural. However, unlike 19th century doctors, though current surgeons aim to preserve sexual sensation there is evidence that genital surgery diminishes this (see chapter 9). Some intersex people also underwent clitorodectomies as late as during the second half of the 20th century (see chapter 7), and indeed Money recommended this procedure during the 1960s (see chapter 4).

\section{The colonial "gaze" (and abhorrence)}

Postcolonial feminist theory rejects a "hierarchical, patriarchal system" represented by "the hegemonic white male" (Caslin, 2012), and is concerned about oppression and injustice caused by imperialism. Truby King's and Barraclough's eugenicist and 
imperialistic ideals in New Zealand reflect British colonial attitudes to gender and sexuality in other countries, such as India's "third gender" hijra community.

Photographer Bruno Morandi asserts that British colonisation influenced India's constitution to adopt Britain's two-gender system and legally prohibit homosexuality, and forced hijras to "officially identify themselves as men" (Morandi, 2012). Morandi states that, prior to colonisation, during India's Mughal period (1526-1707) hijras held revered and prestigious positions as eunuchs and government consultants (ibid.), whereas today they experience discrimination and harassment (Shields, 2010). Serena Nanda, Professor of Anthropology at City University of New York, comments on indigenous cultures which "value gender bending and blending" and remarks: "The question I would ask is why Western culture, especially in the US, is so transgender phobic" (Nanda; in Shields, 2010).

Amongst Maori communities in New Zealand, the term takatapui historically referred to "an intimate companion of the same sex", while today it has been adopted by many Maori to describe gay, lesbian, bisexual, transgender and intersex identities (Aspin, 2011, p. 118). Maori academic Clive Aspin argues that colonisation and JudeoChristian views undermined "acceptance and celebration of sexual diversity" amongst Maori communities (ibid., p. 113). He further argues that such attitudes, that sexual diversity is "perverse", have become so entrenched in western society that it not only "marginalise[s] those who are perceived to be different", but instigates a sense of power and "privilege" amongst "officialdom" such as medical institutions (ibid., pp. 113-114). Maori academic Ngahuia Te Awekotuku also argues that colonisation - particularly Christian missionaries - enforced heterosexism and a sense of shame amongst indigenous peoples in New Zealand (Te Awekotuku, 1991, p. 37). Crossing gender boundaries featured in the legend of the naming of Whakatane, a town in New Zealand. The story of Wairaka was about a woman who, when she exerted tremendous strength in order to save a canoe, announced: "Kia whakatane au i ahau[:] Let me be as strong as the strongest man" (ibid., p. 37).

Sinead Caslin, of Queens University Belfast, asserts that imperialism is "unequivocally male-centred and [E] uro-centric" (Caslin, 2012). An example of British colonial prejudice and injustice was the case of South African Khosian tribe member Saarti 
Baartman (1789-1815), known as the "Hottentot Venus", who was taken to Britain in 1810 and exhibited as a "curiosity" because of her "pronounced" buttocks and genitalia (ibid.). Caslin's postcolonial feminist argument about imperialism reducing non-white women to stereotypes, because their cultures and race fall outside imperialism's Eurocentric model, is similar to queer theoretical arguments (see chapter 6) about normality, particularly the case of Baartman because her genitals did not match euro-centric norms - hence she was regarded as a "curiosity". The injustice of Baartman being exhibited as a freak further resonates with intersex people's experiences (see chapter 7) of being shown to groups of medical students because their genitals fell outside normal notions of Euro-Western society's two-gender system.

Maori lawyer and academic Carl Mika argues that Western society is obsessed with "causation": an "insistence" to find out causes of behavioural traits regarded as abnormal, such as homosexuality (Mika, 2007, pp. 136-137). Mika argues that genetic determinism has resulted in homosexuality being scrutinised by the "genetic gaze", which led to the belief about a possible "gay gene" inherited maternally on the $\mathrm{X}$ chromosome in gay men (ibid., pp. 137-138). Mika asserts that indigenous peoples regard the West's "urgent need to 'know"' with disdain, particularly with regard to behavioural traits, in which indigenous peoples regard this "need" as eradicating the ability "to just 'be"” (ibid., p. 136).

\section{Second wave feminism - "women's problems" questioned}

During second wave feminism many feminists were concerned about a woman's right to choose on reproduction and sexuality issues (Bunkle, 1998, p. 240). Betty Friedan, a pioneer of second wave feminism and founder of the National Organisation of Women (NOW), argued against "the cult of the 1950s housewife" that had "gripped the US[A]" in her 1963 book The Feminine Mystique (Hoby, 2010; Fox, 2006). A key finding was that many women, depressed by their role expected by postwar-1950s American society, consulted clinicians such as psychiatrists who prescribed them activities such as "charity

\footnotetext{
${ }^{6}$ Though not referenced in Mika's chapter, this indicates a study conducted by Dean Hamer and others from the National Cancer Institute (NCI) in Bethesda, Maryland, of 114 families of gay men (Hamer et al.,1993, p. 321). Results indicated "a statistically significant correlation" between genetic markers on chromosomal region $\mathrm{Xq} 28$, located on the long arm of the $\mathrm{X}$ sex chromosome, and homosexual orientation in males (ibid., p. 321).
} 
work, bowling and bridge" (Fox, 2006). If this was ineffective women were prescribed tranquillisers "to get [them] through [their] busy day" (Fox, 2006).

Friedan's book, it could be argued, was important in that it initiated the development of thinking about women's oppression by male-dominated institutions such as medicine. It could further be argued that "suburban neurosis" was created by psychiatry to keep women in their place (the home) during the postwar-1950s period in America. New Zealand feminist Sue Kedgley states that in New Zealand the term "suburban neurosis" was adopted by psychiatrist Dr Fraser McDonald in 1968 (Kedgley, 1996, p. 221). He had encountered many women with depression caused by the drudgery of their expected roles as housewife and mother, just like their American counterparts (ibid., p. 221). Feminism in New Zealand ignited in 1972 when Germaine Greer visited to promote her book The Female Eunuch (ibid., p. 233). Greer remarked that housework was "slavery" and that women were "stifled and imprisoned" by "conventional motherhood" (ibid., p. 233). This struck a chord amongst many young mothers in audiences at Auckland and Wellington who shared feelings of dissatisfaction as full-time mothers, and some quickly became active in the women's movement (ibid., p. 233).

In Good and Mad Women (1984) Australian historian and feminist Jill Julius Matthews argued about a "gender order" of power relations within a society, that begins at birth when individuals are "differentiated" as male or female (Matthews, 1984, p. 13). Matthews argued that the gender order has particular implications for women in that it creates an "ideology of femininity" - akin to a "checklist" - which outlines what it means to be a "good woman" (ibid., p. 13). The gender order then influences a society to judge women (using the "checklist") on aspects such as "appropriate" appearance and behaviour (ibid., p. 13). She asserted that "[w]hat is at issue is not whether she is a woman" but that "it is a question on what sort of woman" (ibid., p. 15). Matthews" "gender order" argument is relevant today as individuals continue to be differentiated at birth by medicine's first "checklist" item - genital appearance - in order to be classified as male or female. Her "gender order" argument is also relevant today because of medicine's recommendations for rearing as male or female - that children should be differentiated by expected (“judged") behaviours. 
Matthews argued that "deviance" was dealt with by two key institutions in 20th century Australia: the police and the medical profession (ibid., p. 20). While the law dealt with individuals who have intentionally "deviated" against what is socially acceptable and who are punished, medicine deals with individuals who have - through no fault of their own - deviated from social or biological norms and are "treated and cured" (ibid., p. 20). In her research on women admitted to Glenside Hospital ${ }^{7}$ in South Australia, Matthews focused on the medical specialty of psychiatry which, she argued, is very involved in maintaining the gender order by "curing" deviation with the goal of women becoming "good women" (ibid., p. 24). Glenside Hospital's treatment method involved investigating an individual's "personal and social history" in order to find out "what had gone wrong" (ibid., p. 24).

One aspect that the hospital's psychiatrists regarded as a deviation against "feminine normality" (ibid., p. 121) was an inability to "enjoy heterosexual social pleasures" (ibid., p. 121) - thus lesbianism was regarded as a mental illness (ibid., p. 122). Girls who refuse to conform were called "tomboy[s]" (ibid., p. 122) who were disinterested in boys unless "as friends in adventure" (ibid., p 122), were "wallflower[s]" (ibid., p. 121) at dances and did not "groom [themselves] to feminine attractiveness" (ibid., p. 122). While tomboyism was acceptable during childhood, "persistence" in later life was regarded with "seriousness" as "suspected lesbianism" (ibid., p. 122). A psychiatrist's notes about a 15-year-old girl, written in 1968, stated that she had "an unfeminine appearance" (ibid., p. 122), but later expressed "relief" that she "dressed in feminine clothes to attend a ward social" and was "a developing young lass with heterosexual feelings" (ibid., p. 122).

Matthews' argument about how society deals with "deviance" reinforces feminist arguments about the power wielded by medical institutions in that, as in other Western countries, 20th century Australian society regarded clinicians as experts. Many people in turn were often suspicious of behaviours that went against expectations of normality - thus girls and women were sent to the psychiatrists at Glenside Hospital to become normal ("good"). Matthews also outlines clinical practice in accordance with gender

\footnotetext{
${ }^{7}$ Matthews examined 31 cases of women whose first admissions occurred between 1932 and 1970 (Matthews, 1984, pp. 204-205).
} 
stereotypes: girls - particularly older girls on the verge of womanhood - were not supposed to be tomboyish (ibid., p. 122). Friedan (1963; in Fox, 2006) similarly argued that psychiatric practice was based on stifling postwar gender stereotypes: that women were not supposed to be bored and dissatisfied with housework, otherwise there is something wrong with them. Matthews further showed that psychiatric practice was influenced by heterosexism - the notion that girls are supposedly interested in meeting boys at dances. This reinforces Adrienne Rich's argument that compulsory heterosexuality is an "institution" created and enforced by male dominance (Rich, 1981, pp. 5, 9): that lesbian existence has been regarded as "deviant" and "abhorrent", and erased and ignored "in a wide range of writings" (ibid., p. 4).

Despite being published 29 and 50 years ago respectively, Matthews' and Friedan's findings about gender stereotypes (regulated by the speciality of psychiatry) are relevant to my research question on medical rationales for managing intersex conditions. Indeed, the American Psychiatric Association's Diagnostic and Statistical Manual of Mental Disorders (DSM) describes crossing gender identification boundaries (as discussed in chapter 6) as "gender identity disorder" or GID (Factor \& Rothblum, 2008, p. 242). While Matthews and Friedan raised questions about the speciality of psychiatry concerning behaviours, it could be argued that that the speciality of paediatric endocrinology is concerned about physical feminine appearance (via oestrogen administration) - that girls are not supposed to be muscular, flat-chested and "butch"looking (see Factor \& Rothblum, 2008, p. 244). With regard to Matthews' further finding that psychiatric practice was fuelled by fears of lesbianism, when considering Chase's (1998, p. 210) argument about compulsory heterosexuality, the specialty of paediatric surgery appears to be shaped by heterosexual expectations via the surgical creation of a vagina to accommodate a penis. Intersex activist Thea Hillman also asserts that that the "concealment model" of clinical management (as advocated by Money) has been influenced by homophobia, in that the aim of vaginoplasties is so that intersex individuals will lead a "normal life" as heterosexuals (Hillman; in San Francisco Human Rights Commission - hereafter SFHRC, 2004). Friedan's and Matthews' arguments are also similar to Walter's recent argument that, despite feminist activism from those such as Friedan herself, sexism has not "wither[ed] away" (Cochrane, 2010). 


\section{Medical power and status - "the expert"}

Power relations and patriarchy, between mostly-male clinicians and "ordinary" women (Coney, 1988, p. 246), are exemplified by the 1987-1988 Cervical Cancer Inquiry at National Women's Hospital, Auckland. The case, also known as the "Cartwright Inquiry" as then Judge (now Dame) Silvia Cartwright presided over the case, exposed the trauma experienced by a group of women. Without their knowledge or consent the women were used in an "experiment" situ (CIS) (Bunkle, 1988; p. 152). The "experiment", which involved a total of about 1800 women, was initiated by gynaecologist Associate Professor Herbert Green (19162001) and occurred at National Women's Hospital from 1956 to 1982 (ibid., p. 143).

Green held conservative views on women's fertility and argued that women who request sterilisation procedures "[throw] away a unique possession" (ibid., p. 148). He therefore set out to prove that CIS was "a harmless disease" (ibid., p. 148), in order to avoid treatment procedures such as hysterectomies that would render a woman sterile (ibid., pp. 148-149). Green "follow[ed]" a group of women by recalling them for regular cervical smears and examinations - those who returned positive ("abnormal") smear tests remained untreated (ibid., p. 151).

In The Unfortunate Experiment, an account of the Inquiry, Sandra Coney (a feminist health activist who investigated the "experiment" with Bunkle) vividly illustrates the powerful image wielded by clinicians:

There was something larger than human, almost saintly, about the image doctors at the inquiry had of their profession. ... Placed on such a high pedestal, they were effectively inviolate.

(Coney, 1988, p. 234).

Coney again illustrates power relations between clinicians and patients, this time highlighting the stark contrast of the power imbalance between mostly-male clinicians and "ordinary" women:

We have the institution, as hierarchical as the Vatican, ruled over by the pope professor with his priestly clinicians, and serviced by the acolytes/nurses. We have the eminent

\footnotetext{
${ }^{8}$ Medical epidemiologist David Skegg referred to Green's study as "the unfortunate experiment at National Women's Hospital" in a letter to the New Zealand Medical Journal. Skegg's phrase was adopted by Sandra Coney and Phillida Bunkle as the title for their Metro magazine article (June 1987 issue) that exposed Green's study and subsequently prompted the Inquiry (Skegg, 2009, pp. 7-8).
} 
senior clinician, protected by his shroud of clinical privilege and the doctrine of brotherhood; the resident "expert" theologian of the subject of CIS, world traveller, resplendent in his professorial title, trailing his entourage of lesser doctors. Brought to the altar of clinical freedom are the women, working women, mothers, ordinary folk, without degrees, gender status, titles, white coats, or entourages (unless we count children)...

Coney's comments illustrate a distinctive power structure - a binary - between clinicians (men in positions of power) and patients ("the women"). From these comments one can consider a consulting room scenario of intersex people who are often too small (hence powerless) to speak for themselves, and their parents (akin to "the women") who - having little or no medical knowledge - are in awe of the clinician with their prestigious-looking qualifications hanging on the consulting room wall, and revere the clinician as what UK counsellor and therapist Sarah Graham (see chapter 7) called "God in a white coat" (Graham, 2006). The framing of clinicians as "expert[s]" (Coney, 1988, p. 246), I suggest, may be a contributing factor to what convinces parents of intersex children to consent to procedures. Indeed, as Colapinto reports, when Ron and Janet Reimer first visited Money at Johns Hopkins, the mere sight of his diplomas on his consulting room's wall convinced them that one of their twins was going to receive the best possible care (Colapinto, 2000, p. 50). Mrs Reimer remarked that she "looked up to [Money] like a god" and "accepted whatever he said" (Reimer; in ibid., p. 50).

Aside from issues of power, Coney highlights the trauma and harm experienced by the women due to them being denied their "fundamental right" to full information and informed consent (Coney, 2009, p. 69). “Mrs M" was recalled by National Women's 65 times during a 20 year period and underwent 24 procedures, before dying of cervical cancer "still with her uterus intact" (ibid., p. 69). Trauma was experienced not only by the women but also their families. Clare Matheson ${ }^{9}$, herself one of the women who visited the hospital 44 times from 1964 to 1979, outlines Gary’s grief when his mother, who had previously been "in and out of the hospital on numerous occasions", developed cervical cancer and died in 1976 (Matheson, 2009, p. 47). Gary's father, also affected by the worry and stress of his wife's numerous recalls without treatment, had two heart attacks and died "a few years later" after "never [being] the same man again” (ibid., p.

\footnotetext{
${ }^{9}$ Matheson was referred to as "Ruth" in Coney's and Bunkle's 1987 Metro article (Matheson, 2009, p. 53). Matheson's experiences of the "experiment" are outlined in her book Fate Cries Enough (1989).
} 
47). The consequent harm and trauma of Green's experiment is akin to Money's experiment with the Reimer twins: not only did the Reimer twins experience psychological trauma during consultations with Money, but their parents later experienced grief when their children died. Many intersex people have also spoken publicly about similar harm and trauma from irreversible surgical procedures (see chapter 7), as clinicians - and I would assert some parents - were convinced by Money's gender gospel.

The Inquiry - and subsequent Cartwright Report published in July 1988 - marked a turning point on New Zealand's social, political and medical landscape. It resulted in the establishment of patient advocates at hospitals throughout New Zealand, the appointment of a Health Commissioner, the establishment of New Zealand's Code of Health and Disability Services Consumers' Rights - "the first such code to be legislated in the world", and - importantly for New Zealand women - a national cervical screening programme (Skegg, 2009, pp. 7-9). Historian Linda Bryder asserts that her book, $A$ History of the "Unfortunate Experiment" at National Women's Hospital (2009), "sheds new light" on the Inquiry (Bryder, 2009, p. 4). She remarks that, while she was initially "horrified" when she first read Coney's and Bunkle's 1987 Metro article which exposed Green's study, her view about the "experiment" and Inquiry changed after she read medical publications about CIS (ibid., pp. 4-5).

Charlotte Paul, a medical adviser to the Inquiry, asserts that Bryder's book conveys a "revisionist" view by contending that Cartwright "got it wrong" (Paul, 2009, p. 94). Law academic Joanna Manning comments that Bryder's “trivialising” of the women's experiences is "one of the most troubling aspects of her book" (Manning, 2009, p. 21). Indeed, a gynaecologist who reviewed the recalled women, who underwent numerous biopsies performed by Green, "said that he had never seen such mutilated genital organs" (Coney, 2009, p. 147). Bryder dismisses Coney and Bunkle as "two feminists" who "picked up" on the Inquiry to "advance a core element of the new women's health movement" and "attack medical authority" (Bryder, 2009, p. 108). Coney, however, remarks that she and Bunkle "were completely open in [their] methodology" (Coney, 2009 , p. 65) and that they interviewed a wide range of people which included clinicians such as New Zealand cancer specialist Dr Allan Gray (ibid., p. 63). Coney also appears 
to show concern for clinicians: "there were health professionals involved whose careers could be affected by what we wrote" (ibid., p. 63).

Bryder also claims that vaginal examinations on anaesthetised women were "common practice around the Western world" (Bryder, 2009, pp. 130-132) and cites letters of support towards National Women's Hospital from some women: "It does not matter to me who examines me. How else are young doctors to learn. To me, doctors are unsung heroes" (ibid., pp. 134-135). In rebutting Bryder's claim that "women really didn't mind" (Brookes, 2009, p. 112), history academic Barbara Brookes asserts that some clinicians, who trained at National Women's during the 1970s, "recall with shame the lack of respect then shown to women at that institution" (ibid., p. 112). This lack of respect is recalled by some intersex people (see chapter 7), who have spoken about the trauma of being treated like research objects - particularly when fully conscious - by clinicians and entourages of medical students.

Bryder also appears to side with medicine's prestigious element while disregarding unethical research practices. While she remarks that she was initially "horrified by what had taken place in my home town" after reading Coney’s and Bunkle's 1987 Metro article, her thoughts on the "experiment" changed after reading numerous medical publications about CIS of the cervix (ibid., pp. 3-4). Bryder appears to suggest that nonclinical voices such as Matheson's (despite their harrowing experiences) are not as important (see Coney, 2009, pp. 146-147). Power and prestige, as illustrated by Coney, can be seductive so that the experiences of "ordinary folk" (Coney, 1988, p. 246) appear unimportant in comparison. Indeed, Brookes remarks that Bryder's book "supports nostalgia for a past where the word of the god-like professor was unquestioned" (Brookes, 2009, p. 117).

With regard to Coney's (1988, p. 246) church-like illustration, emergency surgery for an ectopic pregnancy in 1978 indeed inspired French artist Orlan to use surgery as an artistic medium (Jeffries, 2009). Medical "mystic[ism]" (Bart, 1981, p. 121) appeared to appeal greatly to Orlan as she arranged for a video crew to film her surgery "and insisted [that] she remain conscious throughout" (Jeffries, 2009): 
Orlan saw the surgeon as a priest-like figure, his assistants gathered round him like fellow celebrants at a Catholic mass. The light from above recalled the heavenly beams that shine down in Bernini's baroque sculpture of Saint Theresa...

(Jeffries, 2009).

Orlan remarks that "when [she] lay on the operating table, the parallels between the operating theatre and the Catholic mass were not wasted on [her]" (Orlan; in ibid., 2009). An acquaintance I encountered recently also appeared to be captivated by medical prestige. She boasted to me that when she had undergone a recent surgical procedure she was, she claimed, the surgeon's research subject of some apparent clinical research he was undertaking. Like Orlan, this acquaintance appeared to revel in her apparent privilege of being "brought to the altar" (Coney, 1988, p. 246) - represented by the operating table - of medical power. In contrast, some intersex people know only too well the experience (without their consent) of being used as medical research subjects and would see straight through the acquaintance's attempt to impress. As outlined in chapter 7, this very issue of "clinical privilege" (ibid., p. 246) not only resulted in feelings of shame but an understandable contempt of medical institutions (de María Arana, 2005, pp. 23, 32, 40).

Like Coney, Professor Ronald W Jones ${ }^{10}$, himself a visiting obstetrician and gynaecologist at National Women's, expresses surprise that "even today some individuals continue to rail against the findings of the Cartwright Report" (Jones, 2009, p. 71). Jones, who describes the "experiment" as "the saddest and most shameful episode in New Zealand's medical history", recalls that many of his colleagues treated him with "open hostility" after the Inquiry was announced, and that the "experiment" reflects "the reluctance of good people to stand up against injustice and powerful individuals" (ibid., p. 88). With regard to the "well-established medical hierarchy" at the hospital, when Dr Bill McIndoe (1918-1986) voiced his concerns about Green's proposal to the Hospital Medical Committee in 1966 "his opinion was taken less seriously than it should have been", due to him being "a quietly spoken doctor at the

\footnotetext{
${ }^{10}$ Jones, with fellow clinicians Dr Bill McIndoe and Dr Malcolm R (“Jock") McLean, and statistician Peter Mullins - all of National Women's Hospital, wrote "The Invasive Potential of Carcinoma of the Cervix" published in the October 1984 edition of Obstetrics and Gynaecology. The article was brought to Coney's and Bunkle's attention in early 1985 which subsequently sparked their investigation (Bunkle, 1988, p. 130).
} 
bottom of the hierarchy" which favoured academic members of the postgraduate school over non-academic medical specialists (ibid., pp. 73-74).

Jan Crosthwaite, an Associate Professor of Philosophy at the University of Auckland, remarks that, while the Inquiry prompted medicine to become more conscious about ethics, it provides an opportunity to reflect on whether an unethical "experiment" could occur again in New Zealand (Crosthwaite, 2009, pp. 170-171). Public awareness helps to counter people's hesitance to stand up to "experts in white lab coats", a hesitance which increases the chance for unethical research or clinical practice to reoccur (ibid., pp. 170-171). Crosthwaite's comment about public awareness assisting people to be assertive in their interactions with "experts" is similar to feminist principles of questioning clinicians and demystifying medical knowledge - that public awareness enables a shift in power relations to occur. Support organisations have also played a part in raising public awareness and empowering people to question supposed experts one factor being the provision and sharing of information via the internet. One can imagine a different consulting room scenario of intersex children and their parents who, from visiting intersex support group websites and meeting support group members, would be far less intimidated by so-called experts in white coats.

Brookes also offers a unique perspective on medical power in small populations, particularly in New Zealand (Brookes, 2009, p. 110). She suggests that this may be the cause of New Zealand's "slowness" to establish birth control services, for example, compared to the UK and USA (ibid., p. 110). Brookes also comments that the clinicians at National Women's “were powerful, and had considerable influence throughout New Zealand" (ibid., p. 110), and suggests that there may be "something particular to New Zealand" in which clinicians were "less subject to scrutiny" (ibid., p. 116). Brookes raises questions on how a "small number" of clinicians can wield a powerful influence on other clinicians' careers that makes it difficult to speak up about unjust practice, and how "dispassionate" peer review can occur "in a society where most academics know each other" (ibid., p. 116).

A photographic project which appears to empower sexual difference - and in turn challenges medicine's pathologising of sexual difference - is Rebecca Swan's Assume 
Nothing, ${ }^{11}$ which was published as a book in 2004 and exhibited at five major New Zealand public galleries during 2008 (Drayton, 2011, p 62). Swan's photographic subjects are representations of gender diversity and queer identity (ibid., p. 62). In countering the medical gaze's policing of categories (Duncan, 1997, p. 137), Swan's photographs can be regarded as "signs of communities that claim their own identities and are not strait-jacketed by rigid definitions of what it means to be male, female or both" (Drayton, 2011, p 62). A postmodern theoretical theme (see chapter 6) emerges from Assume Nothing as it not only challenges the male/female binary code but questions the construction of gender (Butler, 1990, pp. 11-12). A queer theoretical theme (see chapter 6) also emerges in that Swan's project literally provides visibility to non-heterosexual communities, which resonates with a queer political objective about difference (Genz \& Brabon, 2009, p. 124). Assume Nothing's relevance to medical education about intersexuality is discussed in chapter 12, and indeed challenges Western medicine's "gaze" on sexual difference.

\section{The medical "gaze"}

From a feminist perspective, medicalisation is when Western medicine focuses its "gaze" on aspects of women's lives and bodies, considers them "problematic" and then concentrates on undertaking "treatment" (Carryer, 1997, p. 100). Medicalisation particularly focuses on notions of "normal" and "abnormal" (ibid., p. 100). Susan Duncan, a registered nurse in New Zealand, argues that the medical gaze causes bodies to become "text[s] from which sexual difference can be read" (Duncan, 1997, p. 128). As intersexual bodies "blur" the male/female binary code, the medical gaze thus considers this a problem and, as Duncan believes, investigates and assigns a "correct sex" in accordance with Western medical ideals (ibid., p. 128). The medical gaze was indeed prevalent during the 19th century (see chapter 3) when autopsies revealed intersex conditions (ibid., p. 128). James Carey, a "reputed" intersex person who died in 1839, apparently knew that his body would be examined (ibid., p. 128) as outlined in a pamphlet by James Akin (1839):

"And when dire necessity at last required positive aid to relieve his sufferings... he nevertheless essayed in struggling efforts to battle with those who kindly tendered him

\footnotetext{
${ }^{11}$ Kirsty MacDonald also made a documentary film of Swan's Assume Nothing exhibition, of the same title, in 2008 (source: http://www.rebeccaswan.com/assumenothing.htm).
} 
assistance... Such was his horrible dread of being handled or rendered a spectacle subservient to the gaze of others."

(Akin, 1839, p. 4; in Duncan, 1997, p. 128).

Duncan argues that it is the male medical gaze which aims to "subject[ify]" the "heterosexualised" male/female binary code, in relation to intersex bodies which are "different and separable" as "object[s]" (ibid., p. 129). To illustrate this, she further argues that, via the practice of dissection, cadavers become "anatomical object[s] of study" through a discourse that constructs notions about masculinity and femininity (ibid., p. 129). In defining the male medical gaze, Duncan argues that it is "the male observer" who, when dissecting a female body, "find there his own body represented by its absence and difference" (ibid., pp. 135, 137). Thus, she argues, a man has “medically defined himself" from differences which he classified as "Other" (ibid., pp. 136). Furthermore, the medical gaze is extremely powerful in that it not only classifies particular categories but "police[s]" them (ibid., p. 137).

\section{Clinicians and the management of intersexuality}

Dr Yee Low, Professor John Hutson and the Murdoch Children's Research Institute Sex Study Group (all from the Royal Children's Hospital in Melbourne) state: "Western society does not, as yet, recognise any person who does not neatly fall into the 'male' or 'female' category”' (Low, Hutson, \& Murdoch Children's Research Institute, 2003, p. 406). They remark that children born with ambiguous genitalia present a challenge to clinicians in terms of establishing a "rational sex assignment", and that "an understanding of normal sexual differentiation is crucial to understanding these disorders" (Low et al., 2003, p. 406). Your Child with Congenital Adrenal Hyperplasia (1980) is a booklet written by Professor Garry Warne, a paediatric endocrinologist and surgeon also at the Royal Children's Hospital in Melbourne. As well as information about health concerns of $\mathrm{CAH}$, such as the salt-losing types (outlined in greater detail in chapter 5), his information about treatment states: "Girls with CAH usually require surgery to restore the genital appearance to normal. Boys do not” (Warne, 1980). Warne later advises that "[g]irls with CAH usually need surgery to reduce the size of the clitoris to normal, separate the fused labia, and to enlarge the vaginal entrance" and that "[s]ome stretching of the vagina may be necessary later to allow menstruation and comfortable sexual intercourse" (ibid.). 
Low et al.'s remark about Western society's discomfort with sexual ambiguity is similar to Nanda's (in Shields, 2010) argument that Western culture is "so transgender phobic". Warne's remark about boys not requiring surgery, whereas girls do, shows a stark difference between male- and female-assigned children. His comment about "reduc[ing] the size" of an enlarged clitoris also resembles 19th century concerns about a clitoris' "unnatural growth" (Ehrenreich \& English, 1978, p. 50), as well as societal fears towards sexual ambiguity. However, like other clinicians, Warne may be genuinely concerned about the child experiencing teasing in school changing room situations, as will be discussed in chapters 9 and 10 .

Philip Ransley, a paediatric urologist at Great Portland Street Hospital in London, comments that his rationale for removing testes from female-assigned intersex children is to prevent testosterone from "work[ing] its 'evil' work on the brain" - that in order to "successfully" bring up a child as "female then it is absolutely imperative that their testosterone is switched off at birth" (Harper, 2007, pp. 32-33). Ransley also dismisses the option of allowing the child to make full informed consent later in life as a "cop-out" - that "[d]oing nothing is just walking away from the issue" (ibid., pp. 32-33). However, orchidectomy procedures during childhood did not prevent some intersex people (in chapter 7) from preferring tomboyish activities or asserting that they were boys during childhood. In further countering Ransley's assertion, they also wished that clinicians had "[done] nothing" as, they assert, medical procedures had caused more harm than good.

In a further publication, Complete Androgen Insensitivity Syndrome (1997), Warne remarks that in the complete form of androgen sensitivity syndrome (CAIS) "the sex at birth is clearly female" whereas in the partial form of androgen sensitivity syndrome (PAIS), because babies with PAIS are often born with ambiguous genitalia, "a decision must be made about whether to raise the child as a girl or a boy" (Warne, 1997, p. 7). While he advises that the "timing" for removal of testes (due to the risk of cancer) "is a matter of individual choice", he advises that it is "essential" that testes are removed early from children with the partial form of AIS who are being brought up as female, as "failure to do so would result in progressive masculine development" (ibid., p. 17). Like CAH, Warne also advises that clitoral reduction surgery is offered for children with 
PAIS (ibid., p. 17), and that girls over the age of 12 need to have oestrogen supplements administered, not only to provide calcium to prevent bone thinning (osteoporosis) but to promote development of breasts, hips and genitalia (ibid., p. 19). During adolescence, as individuals often encounter "peer pressures to conform", he advises that girls should "learn about their differences compared to others before this pressure to conform becomes dominant" (ibid., p. 22). However, Warne remarks that "counselling services are available" and that "[m] any women find it very helpful to meet other women with AIS" (ibid., p. 23).

It could be argued that Warne's concern about deciding on a male or female upbringing echoes gender stereotypes - the expectation that girls should be treated differently from boys as they grow up. His advice that it is "essential" to remove testes from PAIS children being brought up as female raises a question on whether a PAIS child wants to be channelled towards stereotypically female activities - or if they even identify as a girl. If testes are removed, I would argue that, while it is essential to have supplements to prevent brittle bones, the PAIS child should be fully informed about the effects of oestrogen administration such as breast development - which the child may not want (see Tony Briffa's account in chapter 7). With regard to concerns about children being teased at school, and an endocrinologist's defence of procedures because the prejudices of some parents "run very deep", an intersex person significantly remarks: "It's difficult to be Black [sic] in this culture, too, but we don't bleach the skin of Black [sic] babies" (Kessler, 1998, p. 35).

Paediatric endocrinologist Charmian A Quigley offers a differing view towards intersexuality. As part of a course facilitated by the Lawson Wilkins Paediatric Endocrine Society and Paediatric Academic Societies in Baltimore, Maryland (Accord Alliance, 2011), Quigley remarks that "disclosure" is an "issue" because of the difficulty in telling "bad news": this includes concerns about "potential to harm gender identity or self esteem", the "effect on [the] patient/parent relationship", and - significantly - that "[t]he subject of disclosure is SEX" (Quigley, 2009). She then comments on the "stigma" to "tell the truth": that Victorian era-type attitudes about intersexuality being "taboo" (“don't ask, don't tell") are still prevalent, and that the very subject of "ambiguity" provokes feelings of discomfort and stigma: "is this person 'really' a male 
or female, or something in between?" (ibid.). Consequences of "withholding the truth" include a "shroud of secrecy", "feelings of exclusion, isolation" and "shame", and "a sense of 'freakishness' or 'repugnance"” (ibid.). Quigley's argument, that "ambiguity" raises feelings of discomfort, highlights societal fears and prejudices towards physical states beyond the male/female binary code - which in turn justifies medicine's rationale for "normalising" procedures.

As well as "simply explaining the facts", Quigley lists other "strategies" such as "demystifying" bodies on aspects including "chromosomes" and "gonads", and "emphasis[ing] similarities (rather than differences) between male and female development" (ibid.). She advises that clinicians should "empower the parents to help their child", and that parents in turn should "slowly build information to the child over time" with "age-appropriate details and words" (ibid.). Quigley's advice about explaining the facts and "demystifying bodies" resembles feminist principles of access to full information. Her advice that clinicians should "empower parents" resonates with Coney's (1988, p. 246) illustration of power relations between clinicians (“experts”) and patients, in which Quigley advocates a shift in that power relationship.

\section{Academic perspectives on intersexuality and medical institutions}

UK academic Catherine Harper argues that an "oversize[d]" clitoris "offends" certain cultural expectations by its combination of "maleness" and "femaleness" which disrupts the ideal of proper "feminine" genital appearance (Harper, 2007, p. 74), and that the cultural statement of the penis is that it is "exclusively male" and "a potent symbol of masculinity". Thus intersexuality is "culturally threatening" (ibid., p. 77): a female with an enlarged clitoris creates the "cultural horror" of a "phallic female" (ibid., p. 95) with an "unnatural sexual appetite" (ibid., p. 93). From accounts of people with androgen insensitivity syndrome (AIS), Harper argues that clinicians' rationale for removing testes from female-assigned children is not so much because of the "slight" risk of them becoming malignant, but because they challenge "social-cultural" ideals of the male/female binary code (ibid., p. 111). Thus it is societal fear of the "monstrosity" of a "girl with testes" that unsettles and troubles the male/female binary code (ibid., p. 111). She also argues that, with regard to an Observer (1998) news report of an intersex 
person who experienced violence and harassment, it is this societal "terror" of the "taboo of intersex" that allows continued genital surgeries to occur (ibid., pp. 64-65).

Professor of psychology Suzanne J Kessler argues that the "belief that gender consists of two exclusive types" is regulated by medical institutions and not by biology (Kessler, 1998, pp. 31-32). She asserts that, in managing intersex conditions, "standard [medical] practices" depend "ultimately on cultural understandings of gender", and that clinicians insist that male and female are "the only 'natural' options" (Kessler, 2001, p. 161). Clinicians, Kessler argues, equate gender with genitals and base decisions on phallic size: the "formulation" that "good penis equals male; absence of good penis equals female (ibid., p. 169). From interviews with clinicians, she further notes that gender assignment can be reflected by the clinician's speciality (ibid., p. 169). Paediatric endocrinologists in America usually recommend a female assignment because feminising procedures are less complex (ibid., p. 169). On the other hand urologists, who as surgeons are interested in "fixing pipes and lengthening pipes", tend to recommend a male assignment (ibid., p. 170). An example of a masculine cultural perspective (associated with phallic size) is reflected by a case of an adolescent, who was initially assigned female but "wanted to become a boy":

"He was ill-equipped," said the urologist, "yet we made a very respectable male out of him. He now owns a huge construction business..."

(Kessler, 2001, p. 170).

Canadian academic Morgan Holmes, who founded the Intersex Society of Canada (ISCA), discusses the link between violence and the clinical management of children born with variations of sexual anatomy, with regard to female genital mutilation and “normalising” genital surgeries, as a breach of intersex children's rights (Holmes, 1995). Holmes comments that it is often taken for granted that female genital mutilation is an "act of violence" against women, as it is done to discourage sexual activity while it seriously endangers girls' health (ibid.). She argues that "interpersonal violence" "patriarchal misogyny" - is also prevalent amongst clinicians who justify removing enlarged clitorises because they are deemed "too large" for women (ibid.). With regard to female genital mutilation being common in cultures that place importance on females' virginity, Holmes cites cases of clitorodectomy procedures (in chapter 2) 
performed by Western clinicians during the 19th century to control women's sexuality, and as late in the 1950s to curb masturbation and other notions of feminine vices (ibid.). Holmes' argument about medical rationales for removing enlarged clitorises resembles Quigley's (2009) assertion about Victorian era-type attitudes (feelings of “taboo") towards intersexuality. This is not only because "ambiguity" creates feelings of discomfort, but because talking about intersexuality implies a subject that society is uncomfortable with - "SEX" (ibid.).

"Interpersonal violence" can not only be defined by actions such as assault and torture, but by an individual or a group using power and privilege to control another group of people. Holmes thus argues that abuses of power occur in medical institutions, in which clinicians mislead parents about ambiguous genitalia by using statements such as "nature hasn't finished the job" (Holmes, 1995). She also emphasises the importance of examining the ways in which clinicians exert power and control to convince parents that they are acting in children's best interests, when in fact they are causing their children to experience lifelong physical and emotional trauma (ibid.). Thus, when parents consent to clinicians carrying out "normalising" procedures, they are following a heterosexist regime that people must live as "either male or female" (ibid.). Viewed from Holmes" perspective, David Reimer (see chapter 4) experienced interpersonal violence when Money used his powerful position as a renowned sexologist to convince Reimer's parents to consent to an orchidectomy procedure. The women who visited National Women's Hospital also experienced interpersonal violence. Because of Green's powerful position as "expert" many women kept on visiting the hospital again and again without question. Consequently, like intersex children commented on by Holmes, the women experienced lifelong physical and emotional trauma - if they had not already died from cervical cancer.

UK feminist and psychologist Celia Kitzinger similarly argues that feminism, as a political movement that opposes violence against women, should be "equally committed" to opposing the clinical management of intersexuality that Kitzinger describes as "a form of violence based on sexist devaluing of female pain and female 
sexuality" (Kitzinger, 1999, p. 498). However, Cheryl Chase (now Bo Laurent), ${ }^{12}$ who founded the Intersex Society of North America (ISNA), remarks that many feminists responded to her with a "blank stare" because, as intersex people "are not normatively female or normatively women", some feminists do not regard them as "proper subjects of feminist concern" (Chase, 1998, p. 208; in ibid., p. 498). In The Whole Woman (1999), the sequel to The Female Eunuch (1970), Germaine Greer describes women with androgen insensitivity syndrome (AIS) as "damaged males" and "spurious females": that women are not "real" unless they have XX chromosomes (Greer, 1999, pp. 64, 70-71). Kitzinger describes her disappointment in Greer's book as intersexuality, she asserts, can challenge essentialist arguments about what constitutes male and female categories, and that feminists should not condone "the medical abuse and social oppression" of intersex people in accordance with "a cultural ideology which insists on two, and only two, sexes" (Kitzinger, 1999, pp. 497-498).

Alice Dorumat Dreger and April M Herndon also comment that, while many intersex people found feminist writing on the social construction of gender "empowering and liberating", some intersex women (particularly women with AIS) felt hurt by Greer's arguments about AIS (Dreger \& Herndon, 2009, p. 215). UK academic Iain Morland notes that Greer was "dismissive" when challenged by AIS women and girls and their families: instead of retracting her statements in her book's second edition she "publicly mocked" AIS individuals by calling them men (Morland, 2006, p. 328). Morland argues that "in trying to criticise the social construction of femaleness and intersex, Greer disenfranchised precisely those people who live at the intersection of the two categories" (ibid., p. 328). Indeed, with regard to a case of an AIS individual who was advised by a clinician that she was "completely female" despite a male karyotype, Greer argues that "full-frontal honesty" would have informed the individual that "she was not a woman but a failed male who may pass for a female" (Greer, 1999, p. 70). She asserts that "[c]ruel and unsympathetic though it may seem, women should not automatically accept all those who do not wish to be male as being ex gratia females" (ibid., p. 70). Greer's rationale is that women who accept gender fluidity and "spurious femaleness" weaken

\footnotetext{
${ }^{12}$ In 1995 Cheryl Chase legally changed her name from Bonnie Sullivan to Bo Laurent. However, she was known as Cheryl Chase until 2008 when she started using Bo Laurent "in all aspects of her life" (source: ISNA website, http://www.isna.org/about/chase).
} 
their claim to their own sex, and asserts that gender identity "is never more than approximate" (ibid., p. 73).

I disagree with Greer's arguments about women with AIS as, I suggest, she fails to consider that many AIS women (like many non-intersex women) may have experienced sexism and discrimination because of their common outer physical presentation as female. After all, like their non-intersex sisters, their gonads and chromosome types are not outwardly visible. Her use of the term "spurious" (ibid., p. 73) also appears to take intersex issues back to the 19th century when a medical text (Simpson, 1871, p. 410) used this term (see chapter 3). Greer's labelling of AIS women as "failed male[s]" (Greer, 1999, p. 70) also appears to echo societal fears that "girls with testes" are "monstrosities" (Harper, 2007, p. 111), because their mere anatomy poses a threat to the male/female binary code.

\section{Conclusions}

The 1987-1988 Cervical Cancer Inquiry shows that the power of the medical establishment is a relevant topic even today, in that it is pertinent to intersex rights. Back in the 1980s, if it was not for two feminist activists (Coney and Bunkle) who undertook work following feminist principles, women would have continued to visit National Women's Hospital and consequently there would have been more deaths. Patient rights would also not be as strong in New Zealand as they are now as the Health and Disability Commissioner would not have been established, which could have resulted in further unethical "experiments". The Inquiry is relevant to intersex people's rights as, with regard to Holmes' argument, it is an examination of how clinicians exerted power and control to convince patients (in this case the women) that they were "acting 'in good faith"” (Holmes, 1995), when in fact the experiment caused many women to experience lifelong physical and emotional trauma - some of whom died.

Feminist and intersex activism are political and health movements that have a lot to offer each other. Both are concerned about access to full information, power relations between clinicians and patients, and individuals (instead of clinicians) having control over their own bodies. With regard to Chase's comment about "blank stares" from 
feminists (Chase, 1998, p. 208), intersex people's rights can indeed be a subject of feminist concern as both intersex activism and feminism can hold "interpersonal violence" (Holmes, 1995) as a subject of concern - one issue is genital surgeries on clitorises deemed "too large" (ibid.). Gender stereotypes, in relation to "recommended" sex assignment and rearing, can be another subject of concern for both feminism and intersex activism. Clinicians' recommendations for rearing as male or female reflect Matthews' argument about society's “gender order” (Matthews, 1984, p. 13) where female-differentiated individuals are expected to behave and present in certain ways.

Similarly with Holmes' (1995) and Kitzinger's (1999, p. 498) arguments, intersex activism and feminism can also both hold medical abuse as a subject of concern. In particular, both intersex activism and feminism can work together on analysing power relations between clinicians and patients, and empowering people by demystifying diverse bodies (including intersex and female variance) which in turn empowers them to question clinicians. Women and intersex people have both experienced oppression by medical institutions: women because of their classification as women based on biological factors such as uteruses, and intersex people because of their classification as ambiguous based on biological factors such as phalloclitorises.

With regard to Dreger and Herndon's (2009, p. 215) comment, many intersex people may have found Greer's feminist analyses on gender stereotypes in The Female Eunuch (1970) highly empowering where she raised effective arguments about oppressive gender stereotypes (see chapter 6). Greer's later book enforces essentialist views about what constitutes a "proper" woman, where she dismisses AIS women because they do not meet essentialist criteria such as being born with ovaries and an XX chromosome type. Thus I would argue that Greer's later book disempowers women with intersex conditions because, from Matthews' (1984, p. 15) perspective, her essentialist arguments about AIS women being "spurious females" appear to enforce an "ideology of femininity" - hence a "checklist" of essential criteria.

When considering Warne's (1997, p. 7) advice about children with PAIS, I would question whether one distinct code of behaviour - male or female rearing - is really necessary. I would argue that parents should simply focus on their child's safety and 
Theorising "boy or girl” binary classifications, intersexuality and medical practice in New Zealand

well-being instead of enforcing stereotypical behaviours based on sexual characteristics such as a supposedly adequately-sized phallus. 


\section{Chapter 3: \\ The Romans, the Church and the 19th century: "evil" and "curious" bodies}

This chapter discusses the origins of Western societal thinking about intersexuality. The first two sections outline a shift in attitude from when intersexuality was accepted amongst early civilisations, to the founding of Rome when negative attitudes towards difference emerged. The next two sections outline the Christian Church's rise and influence on society (and subordination of women), medical institutions and 16th century surgeon Ambrose Paré. The latter's attitudes towards intersexuality reflect the Church's teachings of a two-gender, one sexuality system.

The final section on the 19th century outlines another shift in attitude towards intersexuality: from abhorrence to fascination. Like the case of the Hottentot Venus (in chapter 2), 19th century clinicians appeared to revel in discovering "interesting" bodies via dissection and boasting about these in medical texts and journals. Medicine's gaze towards intersexuality thus intensified during the 19th century, particularly with advances such as anaesthesia which enabled clinicians to perform more complex surgeries.

\section{Early civilisations}

Otto Augustus Wall (1846-1922) argued that ancient theories "seem to have taught that the Creator was of hermaphroditic nature" or "androgynous", and cites verse 27, chapter 1 of the Bible's book of Genesis which reads: "So God created man in his own image; male and female created He them" (Wall, 1919, pp. 4-5). The Talmud of the traditional Hebrews similarly states that Adam was created androgynous (ibid., p. 5). God then caused Adam to fall asleep, took sections from all of his bodily parts, and then formed the sections "into ordinary men and women and scattered them throughout the world" (ibid., p. 5). The historic term hermaphrodite came from mythology about Hermaphroditus who was the son of Hermes (or Mercury) and Venus Aphrodite, and "had the powers of both a father and mother" (Gould \& Pyle, 1896, p. 206). Hermaphroditus is portrayed in various mediums in Greek art - one being a statue created by Polycles during the fourth century BC (Young, 1940, pp. 202-203). This 
statue is an early example of intersexuality being accepted in society instead of being regarded as something to be kept secret, and demonstrates differing attitudes between starkly different time periods - the classical period and the latter part of the 20th century (in chapter 4). Wall claimed that in ancient civilisations castrated men were called "hermaphrodites" as, while they had male characteristics, "they were used like women, for coitus in ano" which, he said, "was once an exceedingly popular form of sexual indulgence, known as 'Greek love"' (Wall, 1919, p. 58). He cites a reference to "Greek love" from the Bible's book of Romans, chapter 1, verse 27:

\footnotetext{
"And likewise also the men, leaving the natural use of the woman, burned in their lust one toward another; men with men working that which is unseemly..."
}

(Rom. 1:27; in Wall, 1919, p. 58).

The Good News Bible's (1976) version of Romans chapter 1, verses 26-27, also condemns both homosexuality and lesbianism:

Even the women pervert the natural use of their sex by unnatural acts. In the same way the men give up natural sexual relations with women and burn with passion for each other... and as a result they bring upon themselves the punishment they deserve for their wrongdoing.

(Rom. 1: 26-27, 1976, p. 190).

American urologist Hugh Hampton Young (1870-1945) noted that intersexuality has featured in nearly all religions (Young, 1937, p. 6). The Moabites, believed to have lived during the late second millennium BC, worshipped an "androgynous being called Ashtar-Chemosh" (ibid., p. 6). The Hebrews also stated rules for living for intersex people in their holy book the Tosefta (ibid., p. 7). Bikkurim II, 7 states: "The androgynous has ways in which he resembles men; and ways in which he resembles women; and ways in which he resembles both men and women; and ways in which he does not resemble either" (ibid., p. 7). If an intersex person with male characteristics "becomes unclean by white emission" then he can "[marry] women and not men", but he "must not seclude himself with women" and must "fulfil all the commands of the Torah, like men" (ibid., p. 7). Bikkurim II, 7 also states that if intersex men are "of priestly rank", then "like men" they "must not cut the corners of [their] hair [shave]" (ibid., p. 7). On the other hand, Bikkurim II, 7 states that an intersex person "resembles women" if "he becomes unclean by the issue of blood", then she "must not be alone with men", and that intersex people resembling women are forbidden to "share in the inheritance with the sons", act as a witness and become priests (ibid., p. 7). As in 
ancient Greek society, the Hebrews not only accepted that people had intersex conditions but also acknowledged that they could have status ("priestly rank") in the community, though their holy texts stipulated their male or female cultural role according to "emissions" of menstrual blood or semen. Intersex people were to have a different outcome when Rome was founded.

\section{The founding of Rome}

Young (1937, p. 7) states that soon after Romulus founded Rome, traditionally said to be on 21 April 753 BCE (McGeough, 2004, p. 57), it is believed that he passed a law stipulating that all intersex people should be thrown into the Tiber River (Young, 1937, p. 7). Later, the Romans came to believe that there were more occurrences of intersex people amongst foreigners and that their birth "was an omen of extreme crisis in the state" (ibid., p. 8). As a result they were executed, exposed on a desert island or "removed" (ibid., p. 8). Romulus' opinion may have been influenced by ancient Roman religious beliefs, particularly by the mythologies of the deities Uranus ("male") and Gea ("female") who were brutally separated when they "sexual[ly] embrace[d]" as an intersexual entity (Wall, 1919, p. 3).

Romulus' opinion suggests eugenicist notions, akin to concerns by Truby King and others (in chapter 2) many centuries later about "unfit" people threatening the European race (Kedgley, 1996, pp. 40-41). Foreigners who entered the city of Rome often experienced prejudice as Gauls, for example, were mocked by Romans for their hair and clothes such as the wearing of trousers. Negative Roman attitudes to foreigners may have also been influenced by the fact that a large proportion of slaves in the city were foreigners (Erskine, 2010, p. 82). But in Pliny's ${ }^{13}$ time, during the first century, intersex people became eligible to marry which indicates a shift in Roman attitudes (Young, 1937, p. 8). Nevertheless, during the medieval period intersex people were forbidden to be judges, advocates or university rectors "because they had been branded by nature" (ibid., p. 8).

\footnotetext{
${ }^{13}$ Gaius Plinius Secundus (23/4-79 AD), known as "Pliny the Elder", wrote the 37-book encyclopaedia The Natural History in Latin. His nephew Gaius Plinius Caecilius Secundus (c61-c122 AD), known as "Pliny the Younger", was governor of the province of Bithynia-Pontus at about 110 and published 10 books of letters (Erskine, 2010, pp. 122-123).
} 


\section{The medieval period}

The medieval period (known as the "Middle Ages") occurred from the fall of the Roman Empire in 479 AD till the fall of Constantinople in 1453 (Brodsky, 2008, p. 23). Christianity had become the "official religion" of the Roman Empire in $324 \mathrm{CE}$ (McGeough, 2004, p. 92) when Constantine, emperor from 307 to 337 CE (ibid., p. 313), gained control of the area (ibid., p. 92). Initially he had approached the Church for support (ibid., p. 91) but, according to the Christian writer Eusebius (c260-340 CE) (ibid., p. 315), the night before a battle in 312 - which Constantine and his army won he had a vision of "a Christian symbol blazing against the sun" (ibid., pp. 91-92). The religion of the ancient Romans was then replaced by the Christian Church with its hierarchical organisation of deacons, priests and bishops, and the Pope soon became "the most powerful figure in Western Europe" (Brodsky, 2008, p. 23). The Good News Bible (1976) states that the book of Romans was really a "Letter to the Romans" written by Paul ${ }^{14}$ in preparation of his visit to the Church at Rome, where he intended to work amongst the Christians there (Rom. "Introduction", 1976, p. 189). Paul travelled to Rome from Caesarea, north of Jerusalem (map, New Testament; 1976, p. 184), but had visited Athens during his "second journey" beginning from Jerusalem (ibid., p. 170). From the book of Roman's condemnation of homosexuality (Rom. 1: 26-27, 1976, p. 190) cited previously, it appears that Paul noticed "Greek love" amongst the locals during his visit to Athens.

Illness was consequently regarded to be caused by the devil or the Church's interpretation of "evil" (ibid., p. 23) and Constantine, according to Eusebius, ordered that intersex people be executed (Young, 1937, p. 8). Ancient libraries were destroyed by "barbaric invasions" (Brodsky, 2008, p. 23). However, Arab conquerors managed to retrieve many ancient Greek and Roman texts, and these were translated and preserved by Arab and Jewish scholars after Islam was founded in 632 AD (Brodsky, 2008, p. 23). Arab and Jewish scholars also founded new libraries, universities and a hospital system which introduced pharmacy and chemistry into medical practice (ibid., p. 23). Despite a medical school being founded in Salerno, Italy, during the 11th century the

\footnotetext{
14 "From Paul, a servant of Christ Jesus and an apostle chosen and called by God to preach his Good News" (Rom 1:1, 1976, p. 190).
} 
Church wielded control over the medical curriculum by ordering that theology be included in it - though it did include the "ancient" medical theory of Hippocrates and Galen thanks to Arab and Jewish scholars (ibid., p. 25). During the late medieval period (from about 1000 to 1500) the Christian Church of Rome aimed to enforce its doctrine on Western society: this goal led to the papal Inquisition and consequent subordination of women (ibid., p. 27). The Church advocated the belief that a woman's role was only to procreate, bring up children and "serve their husbands" (ibid., p. 27). Women who "deviated" from this belief, which included women healers and midwives with their own ways of doing things, were accused of witchcraft and heresy (ibid., p. 27). Consequently, thousands of women were executed during the medieval period (ibid., p. 27). The rise of the Christian Church thus stipulated women's place and role in society.

\section{The 16th century - Ambrose Paré}

In The workes [sic] of that famous Chirurgion Ambrose Parey [sic] (1649), Ambrose Paré (1510-1590), principal surgeon to "two or three" kings of France, ${ }^{15}$ defined "sex" as "no other thing than the distinction of Male and Female" (Paré, 1649, p. 590). In his preface "Of the Generation of Man" ("The twentìe [sic] fourth Book") Paré drew from the principles of the Christian Church:

God, the Creätor [sic] and maker of all things, immediately after the Creätion [sic] of the World, of his unspeakable counsel and inestimable wisdom not onely [sic] distinguished mankinde [sic], but all other living creatures also into a double sex, to wit, of male and female; that so they beeing [sic] moved and enticed by the allurements of lust, might desire copulation, thence to have procreätion [sic]. ... In this conjunction or copulation replenished with such delectable pleasure, (which God hath chiefly established by the law of Matromonie, [sic]) the male and female yeeld [sic] forth their seeds, which presently mixed and conjoined, are received and kep' $t$ [sic] in the female's womb.

(Paré, 1649, p. 590).

Paré draws from a powerful institution - the Christian church - to convince clinicians that there can be no other sexes than male and female, with his statement that God "distinguished mankind" by a "double [binary] sex". Paré also appears to enforce a cultural meaning on male and female bodies with his comments about men and women having heterosexual intercourse for the purposes of reproduction - that is, "men have sex; women have babies" (Chase, 1998, p. 210). Thus, according to Paré,

\footnotetext{
${ }^{15}$ From translator Thomas Johnson's “To the Reader” section (Johnson; in Paré, 1649, p. xiii).
} 
heterosexuality is compulsory (via the "law of Matromonie") to serve the purpose of reproduction.

On intersexuality, Paré remarked: "The Hermaphrodite is of a doubtfull [sic] nature, and in the middle of both sexes seems to participate of both Male and Female" (Paré, 1649, p. 20). Paré later commented on "four differences", the first being "the male Hermaphrodite who is a perfect and absolute male" and has only "a slit in the Perineum not perforated" from which "neither urine nor seed ${ }^{16}$ doth flow" (ibid., pp. 655-656). The second difference is "the female, which besides her natural privitie [sic], hath a fleshie [sic] and skinnie [sic] similitude of a man's yard [penis], but unapt for erection and ejaculation of seed" (ibid., pp. 655-656). The third difference are those who "bear the express figures of members belonging to both sexes, commonly set the one against the other, yet are found unapt for generation, the one of them only serving for makeing [sic] of water". Finally, the fourth difference "is of those who are able in both sexes, and thoroughly perform the part of both man and woman" as they have "the genitals of both sexes complete and perfect" (ibid., pp. 655-656).

The Christian church's doctrine of a two-sex system - and penalty for blurring this emerges from Paré's assertion that:

\begin{abstract}
the Laws command those to chuse [sic] the sex which they will use, and in which they will remain and live, judging them to death if they bee [sic] found to have departed from the sex they made choice of, for som [sic] are thought to have abused both, and promiscuously to have had their pleasure with men and women.
\end{abstract}

(Paré, 1649, p. 656).

As well as asserting the "Laws" (ibid., p. 656) of a powerful institution (the Christian Church), Paré's comments are also similar to the Bible's book of Romans' reference to "Greek love" (homosexuality), about men committing what were regarded as indecent acts. Paré's advice to determine male or female assignment was based on anatomical characteristics such as phallic size and vaginal capacity (for heterosexual intercourse), which continue to be echoed by clinicians five centuries later (see chapter 9):

for if the matrix [vagina] bee [sic] exact in all it's [sic] dimensions, and so perforate that it may admit a man's yard, if the courses [periods] flow that waie [sic], if the hair of the head bee $[$ sic $]$ long, slender and soft, and to conclude, if to this tender habit of the bodie $[s i c]$ a

\footnotetext{
${ }^{16}$ The latter term spermatozoa literally means "seed animals" (Maxson \& Daugherty, 1989, p. 123).
} 
timid and weak condition of the minde [sic] bee [sic] added, the female sex is predominant, and they are plainly to bee [sic] judged women. But if they have the Perineum and fundament full of hairs, (the which in women are commonly without anie [sic]) if they have a yard of a convenient largeness, if it stand well and readily, and yield seed, the male sex hath the preheminence $[s i c]$, and they are to bee $[s i c]$ judged men.

(Paré, 1649, p. 656).

However, Paré remarked that if the formation of both genitals are

alike in figure, quantitie [sic], and efficacie [sic], it is thought to be equally able in both sexes: although in the opinion of Aristotle, those who have double genitals, the one of the male, the other of the female, the one of them is always perfect, the other imperfect.

(Paré, 1649, p. 656).

On eunuchs, Paré advises that their nature "is to be referred to that of women, as who may seem to have degenerated into a womanish nature, by deficiency of heat; their smooth body, and soft and shrill voice do very much assimilate women" (ibid., p. 20). He also advises the reader to consider "that there be some Manly [sic] women, with their manly voice, and chin covered with a little hairiness", and that "there are some womanising, or womanish men, which therefore we term dainty and effeminate" (ibid., p. 20). Paré's comments resonate with Greer's argument (see chapter 6) about "castratedness" with regard to female gender stereotypes: that women's bodies must be "hairless" and smooth (Greer, 1970, p. 69). Paré's description of "[m]anly women" also suggests these individuals had $5 \alpha$-reductase deficiency, a cause of male pseudohermaphroditism discussed in chapter 5.

During Paré's time nothing could be done to prevent individuals from becoming "manly", as surgery was not advanced enough to consider an orchidectomy and endocrinology was non-existent to consider oestrogen replacement at puberty. Despite surgery's lack of advancement, Paré stated five principles of "Chirurgical Operations":

Five things are proper to the duty of a Chirurgeon; to take away that which is superfluous; to restore to their places such things as are displaced; to separate those things which are joyned [sic] together; to joyn [sic] those which are separated; and to supply the defects of nature.

(Paré, 1649, p. 1).

In his section ("the seventeenth book") on surgical "cures", Paré also outlined surgical procedures for hypospadias and chordee (“bent” penis):

Som [sic] at their birth, by evil conformation, have not had their Glans perforated in the middle, but have only a small hole underneath, toward the bridle and ligament of the yard, 
called the [spermatic] cord. Which is the caus [sic], that they do not make water in a straight line, unless they turn their yard toward their bellie [sic], neither by the same reason can they beget children, becaus [sic] through this fault of conformation, the seed is hindered from being cast directly into the womb. The cure is wholly chirurgical [sic], and is thus performed. The prepuce [foreskin] is taken hold of and extended with the left hand, but with the right hand, the extremetie [sic] thereof, with the end of the Glans, is cut even to that hole which is underneath. But such as have the bridle or ligament of the yard too short, so that the yard cannot stand straight, but crooked, and as it were turned downwards; in there also the generation of children is hindered, becaus [sic] the seed cannot bee [sic] cast directly and plentifully into the womb. Therefore this ligament must bee [sic] cut with much dexteritie [sic], and the wound cured after the manner of other wounds, haveing [sic] regard to the part.

(Paré, 1649, p. 419).

The 16th century saw the achievement of "controlling haemorrhage" and preventing bleeding during invasive surgery, in which Paré observed that when performing amputations it was more effective to ligate individual blood vessels than to use "mass ligation of tissue" methods or hot oil (Rutkow, 2008, pp. 4-5). Reflecting the Christian church's principle of a "double sex" (Paré, 1649, p. 590), Paré advised that the purpose of surgery was to correct bodies deemed "abnormal" (the "defects of nature"). Paré's use of words such as "evil conformation" can be regarded as an early example of the pathologising of intersexuality. His pathologising of hypospadias, I suggest, was again based on reproduction the "natural" way (via heterosexual coitus) when he comments about "the seed [being] hindered" (ibid., p. 419). Paré further uses urination - the ability to urinate standing up - to pathologise hypospadias, merely because a maleclassified individual "do[es] not make water in a straight line" (ibid., p. 419). Five centuries later, hypospadias continues to be pathologised (see chapter 9) - merely because of a male-assigned individual's inability to urinate in a stereotypically Western male manner (see Money \& Tucker, 1975, p. 67). In countries such as India both men and women usually squat to urinate.

\section{The 19th century - dissections, discoveries and "interesting cases"}

By the 19th century medical study and practice had shifted away from the Church's authority and influence to become a more scientific-type discipline (see Potts, 2002, p. 22), particularly with advances such as anaesthesia and the development of scientific equipment such as microscopes. In Principles of Surgery (1842) James Syme, professor of clinical surgery at Edinburgh University and surgeon to the Queen, described "a very simple operation" if menstrual flow is being prevented by "a membrane" ("a congenital 
imperfection") at the vagina's "orifice" (Syme, 1842, p. 414). "All that is necessary", Syme said, is "to divide the membrane with a knife or scissors, and interpose a piece of lint between its cut edges" (ibid., p. 414). On the other hand Syme advised that, though the "non-appearance of the menses at the usual period of life" should "always lead to an inquiry respecting the conformation of the parts", in a few rare cases the vagina "has been found altogether wanting [lacking] for part of its extent, in which cases, of course, nothing can be done in the way of a remedy" (ibid., p. 414).

Syme's comment that "nothing can be done" suggests that, prior to medical advancements in later times, variations of sexual anatomy were left alone by clinicians. Prior to 1846, while pain-relieving agents such as hashish and opium had been used for thousands of years, surgeons still feared performing surgery as it was not without pain (Rutkow, 2008, pp. 6-7). Surgeons consequently endeavoured to complete operations as quickly as possible with less concern over their surgical technique, while patients refused or delayed procedures for "as long as possible" rather than experience the “personal horror" of surgery while fully conscious (ibid., pp. 6-7). But on 16 October 1846, at Massachusetts General Hospital, Boston dentist William T G Morton (18191868) used sulphuric ether on a patient to remove a small tumour from a patient's neck (ibid., pp. 6-7). While this discovery resulted in ether being used in hospitals throughout the world, it did not expand the scope of surgical procedures till Joseph Lister (1827-1912) noted the effectiveness of using chemical antisepsis and asepsis ${ }^{17}$ (ibid., pp. 6-7). Without the control of infection, patients had a high chance of dying from major surgical procedures (ibid., pp. 6-7).

\section{In Anaesthesia, Hospitalism, Hermaphroditism (1871), ${ }^{18}$ Edinburgh University} professor of midwifery Sir James Y Simpson (1811-1870) described numerous intersex cases and divided intersexuality into two types: spurious (now known as pseudohermaphroditism) and true hermaphroditism (Simpson, 1871, p. 407). In "spurious hermaphroditism in the female" (ibid., p. 410), he remarked that "[w]hen the female clitoris is increased greatly in size, it is not wonderful that it should be

\footnotetext{
${ }^{17}$ Asepsis: the "complete absence" of micro-organisms such as bacteria or fungi that may cause disease (Oxford, 2003, p. 53).

${ }^{18}$ After Sir James' death, the book was edited by his son Sir W G Simpson.
} 
sometimes mistaken for the male penis" (ibid., p. 412). Simpson's comment about enlarged clitorises suggests a precedent for clitoral reduction surgeries in the next century when surgery became more advanced. His comment further echoed Victorian attitudes towards women with enlarged clitorises (Ehrenreich \& English, 1978, p. 50), as well as society's "cultural horror" of a "phallic female" (Harper, 2007, p. 95).

Simpson claimed that when female pseudohermaphrodites reach puberty the "internal reproductive organs" profoundly influence "the development of the peculiar general conformation and moral character of the female" (Simpson, 1871, p. 414). He also said that "the features are sometimes hard, the figure and gait rather masculine, the mammae [breasts] slightly developed, the voice is deep toned, and the chin and upper lip are occasionally covered with a quantity of hair" (ibid., p. 414). In "some marked cases" Simpson stated that "the whole external character approaches that of the male, or, more properly speaking, occupies a kind of neutral ground between the two sexes" (ibid., p. 414). Marie Madeline Lefort was, he remarked, one "interesting case" of "spurious [female] hermaphroditism" who was exhibited in Paris in 1814 when she was 16 (ibid., pp. 415-416). Much of Lefort's physical characteristics appeared masculine, such as the proportions of her shoulders and pelvis, and "the volume of the larynx" and the tone of her voice resembled "those of an adolescent male" (ibid., p. 416). Her clitoris was 27 centimetres long - longer when erect - and below it was an opening where urine and menstrual fluid was passed (ibid., p. 416). Lefort had been menstruating regularly since she was eight, "considered herself a female, and preferred the society of men" (ibid., p. 416). Simpson remarked that, despite Lefort having male secondary sexual characteristics and some marked masculine genital development (ibid., p. 416), the "well-ascertained" fact that Lefort menstruates "can leave no doubt as to the nature of her sex" (ibid., p. 417).

A case of "lateral [true] hermaphroditism" was found in Dublin in 1851 (ibid., p. 441). The individual, a 26-year-old convict who died of phthisis, ${ }^{19}$ had been baptised female but was later brought up as a male on account "of the increasing size of the organ representing the penis" (ibid., p. 442). During his life the individual's "general

\footnotetext{
${ }^{19}$ Phthisis: any disease that results in tissues wasting (Oxford, 2003, p. 533).
} 
configuration and appearance were those of a man" (ibid., p. 443) and "he excelled in several of the manly exercises" (ibid., p. 442). Dissection revealed a fallopian tube which "was found to rest on an ovary" on the left side, and on the right was a teste with a vas deferens (ibid., p. 442). Simpson, who saw and "examined the malformed parts in the College of Surgeons' Museum" in Dublin, noted that the penis was "of the usual size and structure of that organ in the male adult" and that a "small vaginal orifice" with a "very narrow vaginal canal" led up to a "small well-formed uterus" (ibid., p. 442). A small amount of fluid taken from the vas deferens "had the peculiar odour and consistence" of semen but, when examined under a microscope, no spermatozoa were seen: “only numerous cells containing granules” (ibid., p. 442).

Simpson's comment that the individual "excelled" in "manly exercises" (ibid., p. 442) suggests that he was happy participating in traditionally male pursuits involving physical exertion which, I suggest, his male upbringing would have allowed. Despite the individual's initial classification (by baptism) as female it is possible that his parents, on noticing their child's genitalia, felt that he should be brought up as a son because of a cultural view that penises are an "exclusively male" property (Harper, 2007, p. 77). However, the parents may have thought that rearing as male would be in their child's best interests. As discussed in chapter 9, many parents even today are unaware about intersex conditions and merely regard children with penises as boys. The individual, I would argue, may have also experienced a very different outcome if he had been born during the 1960s - when Money's “gender policy” (see chapter 4) was in full force. Even if the parents had taken their child to a clinician for "expert advice", the clinician echoing Syme (1842, p. 414) - may have advised that "nothing [could] be done" surgically. Because surgeries such as laparotomies (which would have revealed the individual's uterus) - and consequent feminising surgeries - were non-existent during the early part of the 19th century, I would argue that the individual may have had a happier outcome than other intersex people born during the next century (which chapter 7 discusses in detail).

A case of "double [true] hermaphroditism" was reported in Amsterdam in 1846 (Simpson, 1871, p. 478). The dissection revealed a teste and ovary on the left side and "these and other [less developed] parts" on the right, "two rudimentary [f]allopian 
tubes" and two "more perfect" vasa deferentia, and a vagina and uterus (ibid., p. 478). The individual had been "considered a female" and "dress[ed] as such" till the age of 38 , when three clinicians undertook examinations and stated in a certificate that he was "a hypospadiac or malformed male" (ibid., p. 479). The individual "subsequently assumed the male attire - a conclusion which seemed to be further corroborated by the absence of menstruation" (ibid., p. 479). Simpson remarked that the autopsy (the individual died at age 58) showed "how difficult or indeed impossible it is, during life, to pronounce always decidedly and correctly on the actual sex of such malformed individuals" (ibid., p. 479). Simpson's comment on the "difficult[y]" of sex assignment "during life" suggests a precedent on the "importance" of ultrasound examinations on CAH individuals, for example, to detect a uterus in order to determine a "correct female assignment" (Forest, 2001, p. 1997).

Indeed, Mani Mitchell's (see chapter 7) status amongst her own community unbeknown to her at the time - changed from male to female on the mere surgical finding of a uterus (Keir, 2002). While some individuals baptised as male and female may have lived happily all their lives as such, others who were certified differently by medical "experts" during their lifetimes may not have been happy with the thought of "assum[ing]" - if they were certified as female - a restrictive crinoline or whalebone corset. Resonating with Ehrenreich and English's (1978, pp. 43-45) argument, some individuals may have felt very angry and devastated that their new designation as female would mean a barrier to pursuing a higher education as, according to 19th century clinicians (in chapter 2), this "would atrophy the uterus" (Ehrenreich \& English, 1978, p. 45).

While Simpson described various cases of intersexuality in detail, his book does not mention any correcting surgical procedures performed (endocrinology was also nonexistent during his time). He does, however, describe the effects of removing testes or ovaries "by operation" (Simpson, 1871, p. 482), particularly on secondary sexual characteristics. A "well-known case recorded by Mr Pott" (in Surgical Works(iii), p. 329) was a "healthy and stout" 23-year-old woman whose ovaries developed tumours, and were consequently "removed by operation" as they prevented her from working (ibid., pp. 481-482). As a result "the catamenia [menstruation] became suppressed, the 
mammae [breasts] disappeared, and the body became thinner and more masculine" (ibid., p. 481). With regard to observations of castrated male and spayed female cattle, Simpson advised that one should consider the organisation of male physiology to be formed towards "the individual", and the organisation of female physiology to be formed towards "the species" (ibid., p. 490). Thus, "when females are malformed in the sexual parts so as to resemble the male" they become incapable of "performing the action allotted to them in the reproductive process" (ibid., pp. 490-491). Such malformations, Simpson said, prevent them from carrying out their "particular office in the continuation of the species" (ibid., p. 491).

In Anomalies and Curiosities of Medicine (1896), Philadelphian doctors George M Gould and Walter L Pyle described a "law of evolution" in intersexuality "which prevents perfection", that "if one set of genitalia are extraordinarily developed" then "the other set are correspondingly atrophied" (Gould \& Pyle, 1896, p. 211). Gould and Pyle commented on intersex cases "in which the sex cannot be definitely declared - that even dissection cannot "indicate the predominating sex" (ibid, pp. 211-212). Such cases are referred to as "neuter hermaphrodites" (ibid., p. 212). They remarked that intersex individuals have been "accredited" as "having performed the functions of both father and mother", despite statements from "some of the best authorities that they are always sterile" (ibid., p. 206). According to observation, Gould and Pyle state that the "sexual appetite" of intersex individuals "diminishes in proportion to the imperfections in the genitalia, and certainly many of these persons are sexually indifferent” (ibid., p. 206). This remark appears to set a precedent for the next century's rationale on "normalising" genital surgeries: the notion that surgery on a child's ambiguous genitalia may remedy sexual function later in life - that if surgery is not undertaken then the ability to have "normal" (hetero)sexual intercourse becomes diminished.

\section{Conclusions}

It could be argued that, from these historical texts, the founding of Rome and the Christian Church were key influencing factors in a shift in attitude towards intersexuality: from acceptance to repugnance. Indeed, the Church influenced thinking that illness was caused by the devil, the Church's interpretation of "evil" (Brodsky, 
2008, p. 23), which is represented by Paré's description of intersex anatomy as an "evil conformation" (Paré, 1649, p. 419). The Christian Church's rise and influence could further be argued to be a key influencing factor of Western modes of thinking: the notion that there are only two sexes and one (hetero)sexuality. Pare further reflected the papal Inquisition by advocating that individuals, who deviate from their (hetero)sex role stereotypes as male or female and have non-heterosexual intercourse, should be executed. As discussed in chapter 2, Christian-centric thinking in later times resulted in hijra communities in India losing their rights, status and identity when the British imposed Christian-centric ideals, which not only prohibited homosexuality but forced hijras to call themselves male (Morandi, 2012). Indigenous peoples in New Zealand were also affected by Christian missionaries' repugnance towards sexual and gender diversity (Te Awekotuku, 1991, p. 37).

While clinicians during the 19th century appeared to be more and more intrigued by intersex bodies via dissections and surgical advances, surgery was not as advanced as in the next century. This, I suggest, meant that some intersex people during the 19th century may have led happier lives than many of their 20th century counterparts whose assigned sex was - thanks to advances in surgery and endocrinology - surgically and hormonally forced upon them. Furthermore, as laparotomies and radiological examinations (such as ultrasound scans) were non-existent, some may have never known that their internal sex organs were discordant with their baptised sex. As Simpson noted, it was only when some individuals had died that their conditions were revealed during dissection. The case of the 26-year-old individual who was baptised female but later regarded as a male, and "excelled" in "manly exercises" (Simpson, 1871, pp. 441-443), also suggests that gender fluidity to some extent was accepted in parts of Western society. Indeed, the lack of surgery possibly suggests that clinicians considered that they had to allow for gender fluidity.

Despite a lack of surgical advancements, the power of medical institutions in society is evident when some individuals were reassigned (with a certificate) as male or female after being examined by clinicians, on account of supposedly essential criteria such as menstruation (ibid., p. 417). While Simpson stated that "correct" sex assignment was “difficult” or “impossible” during an individual's lifetime (ibid., p. 479), Money’s 
The Romans, the Church and the 19th century: "evil" and "curious" bodies

gender gospel, discussed in the next chapter, convinced many clinicians that this was possible with advances in endocrinology and surgical techniques. 


\section{Chapter 4:}

\section{The 20th century: natural variations and "nature versus nurture"}

The beginning of the 20th century, particularly the horrific injuries experienced by soldiers fighting in the First World War, saw the development and advances in reconstructive surgery such as skin transplants (Rutkow, 2008, pp. 15-16). While advances in surgery occurred during the last century, so did different modes of thinking towards intersexuality. This chapter thus outlines the work of three notable figures in medical history from the 20th century: Magnus Hirschfeld (1868-1935), a pioneering Polish sexologist, Hugh Hampton Young (1870-1945), an American pioneer in the specialist field of urology, and New Zealand born sexologist John Money. As well as outlining particular procedures I will examine differences in thought between Hirschfeld, Young and Money. This is in relation to my research question on medical rationales for managing intersex conditions: my findings show that these were particularly reinforced by Money from the 1950s onwards.

Hirschfeld appeared to assert that intersexuality was a natural variation, and supported Lili Elbe (found to have an intersex condition) in her quest to become physically female. Young appeared to accept that, despite surgeries being performed, an intersex person's gender identity may change. In contrast Money was determined to prove that his recommendations for sex assignment, based on his theory about "gender-identity/role (G-I/R)", had successful outcomes - despite being proven wrong by David Reimer.

The last section outlines the well-known "twins case" because of its profound influence on the medical management of intersexuality, which brought the matter of gender identity to international attention. From Money's point of view the case was supposed to confirm his "nurture over nature" argument, in which a male or female gender can, he claimed, be imprinted on a child via upbringing and medical procedures. Though the twins were born phenotypically male and did not have an intersex condition, a botched circumcision left one of them with ambiguous-like genitalia. 
This chapter also examines issues of power, as discussed in chapter 2. While Young admitted failures and did not, I suggest, set out to prove any argument with his pioneering surgical procedures, Money revelled in his star status as sexological "expert" (Colapinto, 2000, p. 28) and is reported to have reacted angrily (he "had a reputation for tantrums") when challenged (ibid., p. 38). With regard to his reputed star status I suggest that he would have been pleased with Lyons' (1977) News-Letter article title: "Doctor Money speaks, the whole wide world listens". Drawing parallels with the “experiment” and issues of power at National Women's Hospital, I will discuss how Money's power and influence in the medical world was such that the twins case remained unchallenged - until 1997 when Milton Diamond's and Keith Sigmundson's ground-breaking article was published.

\section{Magnus Hirschfeld and the case of Lili Elbe}

In 1918 Hirschfeld founded "The Institute of Sexual Science" in Berlin which contained data, photographs and case studies "on the biology, sociology, pathology and ethnology of sex" (Green, 1935, pp. x-xi). He later formed the "World League for Sexual Reform" with Auguste Forel and fellow pioneering sexologist Havelock Ellis, and in 1932 attended its final International Congress held in Brünn (ibid., p. xi). In his first book Socrates and Sappho (1895, published under a pseudonym), Hirschfeld asserted that individuals with "sexual aberrations" were not "criminals" but "patients whose sex balance had gone wrong" (Green, 1935, p. x). For instance, a phenotypical male's "feeling[s] and behavi[our] as a female" were caused by "too much of the female in his constitution", and that the reverse caused women to be "mental male[s]" (ibid.).

Hirschfeld therefore believed that the subject of transvestitism, which he regarded as a "form of intersexuality" (ibid., p. 81), was crucial "to the theoretical understanding of sex differentiation and of intersexuality" (Hirschfeld, 1935, p. 139). While Hirschfeld asserted that homosexuality was a natural variant instead of a "disease" (Hirschfeld, 1919, p. 455), he appeared to assert the same for intersexuality. During the undifferentiated stage of foetal development, he stated that "all people are physically and psychologically hermaphroditic" and that all men and women retain remnants of their original intersexual state "right into old age" (ibid., p. 432): 
Until the day they die, every man retains his atrophied uterus, the uterus masculinus, and his superfluous nipples; each woman, her aimless secondary testicles [regressed medulla] ${ }^{20}$ and spermatic cords [regressed wolffian ducts]. ${ }^{21}$

(Hirschfeld, 1919, p. 432).

Hirschfeld was also the psychiatrist who supervised Lili Elbe's (1886-1931) pioneering sex reassignment surgeries (History Month, 2011). Elbe was formerly the well-known Danish painter Einar Wegenar (Haire, 1937, p. xv). Wegener experienced monthly occurrences of bleeding from the nose "and elsewhere", which he considered to be a sign of menstruation (ibid., p. ix), and described these occurrences as "haemorrhages" (Hoyer, 1937, p. 89) accompanied by "violent pains" (ibid., p. 92). After being referred to a specialist in France who did not give a "definite" diagnosis, Wegener subsequently read many scientific books on "sexual problems" (ibid., p. 92). From this he formed a view that he "was both man and woman in one body, and that the woman [Lili] was in process of gaining the upper hand" (ibid., p. 93).

In 1930 Wegener visited a renowned German clinician ${ }^{22}$ in Dresden who determined that he was "probably an intermediate sexual type" with rudimentary ovaries and testes (Haire, 1937, p. x). On the clinician's advice Wegener then travelled to Berlin where examinations confirmed an intersex condition, and he subsequently underwent an orchidectomy (ibid., pp. X-xi). A second procedure in Dresden involved removal of his penis and transplantation of ovarian tissue from a "healthy" 26-year-old woman (ibid., p. xi). After a French painter proposed marriage to Elbe (who by then had a new Danish passport in her new name and female status), she revisited the clinician in Dresden and requested another procedure "to function completely as a woman": "to take the female part in intercourse [surgical creation of a vagina], and to become a mother" (ibid., p. xi). Two surgeries were performed in Dresden in June (Hoyer, 1937, p. 249) and August 1931 - the last which she described as "an abyss of suffering" (ibid. p. 253), but on 12 September 1931 Elbe "fell asleep and did not wake up again" (ibid., p. 254). In a letter to a German friend she wrote:

"If the worst should befall... I want you to know that I shall die happy...

\footnotetext{
${ }^{20}$ The medulla and its regression during foetal development are explained in the next chapter.

${ }^{21}$ As per previous footnote.

22 "Professor Warnekros of Dresden, the eminent surgeon who helped to perform the miracle" (Hoyer, 1937, p. iii).
} 
"More than ever, then, I am convinced that it is my moral duty to make my 'Confessions' public, in order to teach people not to judge."

(Elbe, 14 June 1931; in Hoyer, 1937, pp. 244-245).

Hirschfeld's perspective of transvestitism shows an acceptance of gender fluidity, in which he appeared to advocate that crossing of gender boundaries was not pathological but a natural occurrence. This, and his obvious acceptance of intersexuality (that everyone, as he said, retains traces of intersex anatomy all their lives), suggests that he believed that intersex people's bodies should be left alone - unless they themselves requested otherwise. The case of Elbe illustrates this. Elbe also appeared to be on a mission to instil acceptance of gender fluidity, intersexuality and indeed transgenderism, in that she wanted her experiences published so as to dissolve prejudice. Elbe's experiences also highlight the issue of choice - the right to consent to medical intervention. Though Elbe's pioneering surgeries were dangerous and consequently fatal, she was nevertheless happy in the last months of her life.

\section{Hugh Young and the development of urology}

Like Hirschfeld, Young's mode of thinking appeared to show an awareness of gender fluidity. Young said that many people with intersex conditions who came to the Brady Urological Institute $^{23}$ were "often uncertain what their real sex was" (Young, 1940, p. 203). One individual, a 20-year-old male pseudohermaphrodite, had been brought up as female and "attended a fashionable girls' school" two weeks before being examined in 1920 (Young, 1937, p. 52). Girls at the school were apparently extremely attracted to the individual who "began to wonder whether 'she' was really a girl” (Young, 1940, p. 203). The individual visited a doctor "who discovered the true sex" and referred her (as she was then) to Young (ibid., p. 203). The individual had rejected feminine attire, "had the hair clipped" and wore masculine attire "rather awkwardly" (ibid., p. 203). When the individual undressed, Young recalled, "I thought I had before me a girl, but careful examination revealed the true sex, and operations to restore conditions to normal were performed" (ibid.). Surgeries to straighten the penis occurred in 1924, 1925 (Young, 1937, pp. 54-55) and 1926 which, Young claimed, produced “excellent" results (ibid., p. 57). After the final surgery the man (as he became) and the nurse in attendance fell in

\footnotetext{
${ }^{23}$ The Brady Urological Institute, located on the grounds of Johns Hopkins Hospital, Baltimore, was founded by Young and opened on 21 January 1915 (Young, 1940, pp. 225, 227).
} 
love and were married soon after (Young, 1940, p. 203). Young remarked, "The couple have since visited me, and they are apparently very happy" (ibid., pp. 203-204). The case mirrors Tony Briffa's more recent account (see chapter 7) as Briffa is also a male pseudohermaphrodite. However, unlike Young 50 years before, clinicians surgically and hormonally forced a female assignment upon Briffa - despite him telling clinicians that he was "a boy" (Bragge, 2005).

Young believed that it was "sometimes necessary to amputate the penis-like clitoris" (Young, 1940, p. 205) and outlines a case of a seven-year-old from a male orphanage who "had been brought up as a boy" (Young, 1937, p. 84). A laparotomy performed in 1925 revealed a "normal-looking [left] ovary" but none on the right side (ibid., p. 84), a "rudimentary uterus" (Fig. 62; in ibid., p. 86), a vagina (ibid., p. 86) and a "well-formed penis" with "complete hypospadias" (ibid., p. 84). The custodians at the orphanage were then advised that the child was female (ibid., p. 86). In 1927 a physician from the Phipps Psychiatric Dispensary reported that the individual's clitoris "was very annoying to the child", that "she had to wear a suit of underclothes" to prevent other children from noticing and had "a terrible habit of masturbation" (ibid, pp. 86-87). A clitorodectomy was performed because of the "continued masturbation", the "very frequent erection of the clitoris", the "fear of exposure" and because the laparotomy "showed the patient to be "definitely female"' (ibid., p. 87). In 1933 the now 16-year-old underwent a herniotomy and further laparotomy after "complaining of a mass in the left inguinal region [groin]" (ibid., p. 87). Though still in a girls' institution, the individual "declared as soon as 'she' became of age, 'she' would assume male attire" and enter the mechanical trade (ibid., p. 87). The left gonad, previously considered an ovary, revealed "normal looking testicular tissue" and after much discussion it was decided to remove the testis as the "penis" had been removed before (ibid., p. 89). In 1935 the individual "had become more masculine in character and interests, working as a truck driver", and was "apparently happy although living as a male without penis or testicles and with the vagina still present" (ibid., p. 91).

While the child's clitorodectomy because of "continued masturbation" reflects 19 th century medical attitudes towards female "hypersexuality" (Ehrenreich \& English, 1978, p. 47), the child's "fear of exposure" (Young, 1937, p. 87) echoes the rationale for later 
clitoral reduction surgeries: to prevent childhood teasing in changing room situations. However, with regard to Young's comment that the individual was happy "living as a male" with a vagina (ibid., p. 91) during adulthood, he appeared to have accepted and acknowledged that a person's identity and body can be separate entities (Nataf, 1996, p. 18), and that gender may not match an individual's genitalia (ibid., p. 18).

Young also outlined cases which he described as "practising hermaphrodites" as they "led the life of both male and female" (Young, 1937, p. 136). "George S", who saw Young in 1906, was pronounced female at birth but at 14 "dressed and lived as a man" and later married "as a man" (ibid., p. 136). On the difficulty of finding employment and the "expense" of supporting his wife, the individual left his marriage, came to America, resumed feminine clothing and became a man's "mistress" (ibid., p. 136). At times the individual put on masculine attire and had intercourse "as a male" which he "found to be more satisfactory" (ibid., p. 136). For some years the individual experienced heavy nose bleeds every four weeks with an occasional "slight $\mathrm{h}[\mathrm{a}]$ emorrhage" from the urethra, while leading a "vagrant life" having sexual encounters with both men and women (ibid., p. 136). Young comments that the individual refused surgery "to determine sex" (ibid., p. 136) and "he [sic] quickly disappeared" (ibid., p. 138). Young also suspected that the individual was a true hermaphrodite (see chapter 5) as examinations revealed a "hypospadiac penis", apparent testes, "small, undeveloped" impalpable ovaries, a uterus and vagina (ibid., p. 138-139).

"Emma T", a 26-year-old "reared as female", saw Young in 1935 "complaining of abnormal genitalia" (ibid., p. 139). When she was 13, as her periods had not started, her mother took her to a clinician who undertook a vaginal examination and prescribed "medicine" to take orally (ibid., p. 139). The clinician told the individual "nothing about her condition" but that the "medicine" should induce periods which did not occur (ibid., p. 139). From the age of 14 the individual had sexual relationships with girls and at 19 married a man "whom she thought she liked", but found that she was not "excited" by him as she was with girls (ibid., p. 139). While married the individual had a regular sexual relationship with a female and subsequently left her husband, but later married another man (ibid., pp. 139-140). The woman had still never menstruated (ibid., p. 140). Examinations, which revealed a "short, hypospadiac" phallus and a blind-ending 
vaginal pouch, did not suggest a cervix uteri ${ }^{24}$ or other female internal genitalia (ibid., p. 141). The individual commented that she "sometimes" felt she "should like to be a man", and that she "wondered" why she found women sexually attractive instead of men (ibid., p. 142). When asked if she would like "to be made into a man" which would involve removal of the vagina (ibid., p. 142), she replied:

"I don't know about that because that's [vaginal pouch] my meal ticket. If you did that I would have to quit my husband and go to work, so I'll think I'll keep it and stay as I am. My husband supports me well, and even though I don't have any sexual pleasure with him, I do have lots with my girl friends."

(“Emma T”; in Young, 1937, p. 142).

Young's apparent acceptance of gender and genital discord, including the sense that some individuals were happy with their intersexual states, contrasted with Money's arguments during the 20th century's second half.

\section{John Money and the implementation of "gender policy"}

The early 1950s saw a shift in clinical attitudes in the Western world with Lawson Wilkins and his colleagues at the Harriet Lane Home of Johns Hopkins Hospital, Baltimore, USA (Grumbach et al., 2003, p. 962). The newly-introduced group decisionmaking at this institution included husband and wife psychiatrists Joan and John Hampson. ${ }^{25}$ From the late 1950s Money developed his theory of gender identity which was later referred to by his followers as "optimal-gender policy" (ibid., p. 962).

Money's theory about "gender-identity/role (G-I/R)" began with his doctoral thesis Hermaphroditism: An inquiry into the nature of a human paradox which was completed at Harvard University in 1952 (ibid., p. 962). In 1966 the first gender identity clinic opened at Johns Hopkins Hospital in Baltimore, USA, for the treatment of "sexual differentiation problems" (ibid., p. 962). Money's term gender identity/role (G-I/R) is the unity of gender identity - the "inward" sense of "yourself as male or female", and that gender role is the expression of one's gender identity and includes "everything you

\footnotetext{
${ }^{24}$ Cervix uteri: neck of the uterus which links into the vagina (Oxford, 2003, p. 122).

${ }^{25}$ It also initially comprised of Dr Howard Jones (a gynaecologic surgeon), John Money (who had just arrived from Boston), Wilkins' fellows Judson van Wyk and Melvin M Grumbach (a now-emeritus professor of paediatrics at the University of California), George Clayton and Alfred Bongiovanni, the director of the paediatric endocrine laboratory (Grumbach et al., 2003, p. 962).
} 
do and say, that indicates... that you are male or female" (Money \& Tucker, 1975, p. 9). In Sexual Signatures (1975) Money and Patricia Tucker asserted that gender stereotypes (that is, "society's definition of what it means to be a man or a woman") are essential for a society. Gender stereotypes, they said, "embody the general agreement on the roles assigned to men and women, boys and girls" (ibid., p. 8). Money and Tucker argued that humanity's survival depends on "men and women co-operat[ing] as men and women" (ibid., p. 38): gender stereotypes "provide the framework for that co-operation" in order to "protect, feed, shelter, and rear the young" (ibid., pp. 38-39). Money argued that boys and girls should be reared differently according to "genitalia, sex, and reproduction": one aspect was that "boys and girls learn differently how to urinate boys to stand up and girls to sit down" (ibid., p. 67). Money and Tucker's argument resonates with Kate Millett's argument (see chapter 6) that "psychosexual personality" is learnt by children who, via their upbringings and social environment, receive "clues" on "appropriate" behaviour according to their male or female classifications (Millett, 1971, pp. 30-31). Money and Tucker also appear to advocate sex role stereotyping: that people, depending on their anatomy, should be encouraged or discouraged from participating in certain activities. Money and Tucker appear to advocate that a woman's place is in the home and that girls should be discouraged from seeking a career.

With a neonate diagnosed with the partial form of androgen insensitivity syndrome (PAIS), Money and Tucker advised that the "best solution" is a female assignment and rearing "as a girl" (Money \& Tucker, 1975, p. 55), and that surgery can "feminise" the genital appearance by reducing the size of the "clitorine penis" (ibid., pp. 55-56). They warn against male assignment and rearing for PAIS children as, though the phallus "may be capable of erection and orgasm" it will "not be adequate for the male role in sexual intercourse" (ibid., p. 56) Having a "short penis" or if it "has been amputated", Money and Tucker warned, meant that an individual will "not [be] able to reciprocate in coitus" which, they claimed, "can inflict terrible wounds on his ego" (ibid., p. 56). In comparison in the next century, at a hearing on intersex issues by the San Francisco Human Rights Commission (see chapter 7), gynaecologic cancer surgeon Dr Kate O'Hanlon asserts that "[a]dult men with small phalluses can and do learn how to be sexual in ways that satisfy themselves and their partners" (O'Hanlon; in SFHRC, 2004). 
During a male pseudohermaphrodite's early infancy Money recommended that a "trial test of androgen ointment on the penis" should be undertaken (Money, 1968, p. 45). If the penis enlarges and pubic hair begins to grow this, he said, was proof that the body will respond to androgens (ibid., p. 45). Money claimed that, without this "evidence", it would be "preferable" for the child to undergo feminising surgery and be reared as a girl (ibid., p. 45). He also based another factor for female assignment on outward appearance: "Since his body is resistant to the male sex hormone... [h] is voice remains high-pitched, his face unbearded, and his body feminine" (ibid., p. 44). On the other hand, if a male pseudohermaphrodite's "phallic structure is neonatally at least of the same calibre as that of other males of the same age with small-average penises" then male assignment, Money advised, may be more appropriate (Harlow, c1977, ${ }^{26}$ p. 25).

Money further advised that clinicians should consider male assignment for individuals who, despite having an XX (female) karyotype and ovaries, present at birth with "a penis and an empty scrotum" (ibid., p. 25). His rationale for this exception was that the "XX baby has obviously been heavily masculinised before birth" and that "[r]ecords of past cases show that as a girl she will have serious difficulty in getting her romantic or dating life started when she reaches puberty" (ibid., p. 25). Such children brought up as boys would, he said, have "no such problem" but that "living as a girl with a good moral character, such a person tends to feel terrible about her sexual attractions; she is not necessarily lesbian, but there is a bisexual tendency to cope with" (ibid., p. 25). Money's rationale appears to reinforce a patriarchal 19th century attitude that women are not supposed to be sexual (see Ehrenreich \& English, 1978, p. 47) and that women's sexual desires lead to "immorality" (ibid., p. 50). A sexual double-standard thus emerges from Money's comments: a girl with sexual desires is a slut with "a [bad] reputation”, as Matthews (1984, p. 122) has described, whereas a boy is not.

For cases of female pseudohermaphroditism (as with CAH individuals), Money advocated that an "enlarged, masculine-looking clitoris" should be removed entirely (Money, 1968, p. 93). While Money and the Hampsons noted that a clitorodectomy

\footnotetext{
${ }^{26}$ This source was a photocopy of a Medical Tribune article, partly titled "Dr John Money - Part II" in which the issue date was not visible anywhere on the copy. I am assuming it was published the same year as Rhonda Lyons' News-Letter article, which stated at the end "to be continued next week" (Lyons, 1977, p. 4).
} 
procedure was a contentious matter regarding loss of sexual sensation, they claimed that there was "no evidence" of adverse effects from clitorodectomies performed (Money, Hampson \& Hampson, 1955, p. 295). From their studies of women with CAH, Money and the Hampsons claimed that not only had all the women reported a failure to reach orgasm, but that they "express[ed] intense satisfaction" at having more feminineappearing genitalia (ibid., p. 295). In explaining surgery to small children, Money et al. advised that while boys with hypospadias should be told that their penises will be "finish[ed]" in order to "stand up to urinate" (ibid., p. 294), a girl about to undergo a clitorodectomy should be told that "the doctors will make her look like other girls and women" (ibid., p. 295). Girls should also be told that, while boys have a penis, they have "a baby tunnel” (“juvenile vocabulary" for a vagina) as assurance against "childish theories of surgical mutilation and maiming” (ibid., p. 295). Indeed, in a later article Money advised that if girls are not informed about such sexual differences "they may misconstrue their surgery as mutilating rather than corrective" (Money, 1961, p. 480, own italics). Money's claim that the women with $\mathrm{CAH}$ were satisfied undergoing clitorodectomies appears to be a stark contrast with other intersex people's understandings and experiences of this procedure (as discussed in chapter 7). Money also appeared too determinate in claiming that information about reproductive differences would prevent intersex children from regarding their surgery as "mutilating". Intersex activists such as Morgan Holmes - who herself has had a child - argues that such surgery is not only mutilating (akin to female genital mutilation) but traumatic (Holmes, 1995).

Money defined "psychoneuroendocrinology" as prenatal hormones having an effect on the "male/female dimorphism of the brain" (Money, 1987, p. 384). A source of "evidence" was a study of two groups of girls: a "test group" born during the 1950s who were masculinised by synthetic progestins taken by their mothers to prevent miscarriage, and a "control group" of "girls selected to match them as closely as possible" who were not masculinised prenatally (Money \& Tucker, 1975, pp. 68-69). In the test group, the girls' internal sex organs were unaffected but their external genitalia ranged from "zero" to "complete masculinisation" which was "corrected" by surgery (ibid., p. 69). Money and Tucker remark on the key difference - "tomboy" - between the two groups, and cite that "almost all of the test girls were consistently, even boastfully, tomboys throughout 
childhood" (ibid., p. 69), and "like[d] strenuous activity, cavorting about on their bicycles, climbing trees, hiking, and exploring" (ibid., p. 70). But despite their assertiveness, Money and Tucker remarked that the girls in the test group "kept their dominance toned down below the boys' level" because the girls "sense - or learned early - that boys won't easily tolerate a girl who is too pushy" (ibid., p. 70).

Money and Tucker's position represents a classic example of biological determinist thinking (see chapter 6) and gender stereotypes: the expectation that androgens cause masculine behavioural traits such as aggressiveness, and that girls learn behaviour from "clues" which influence them to tone down their "pushy" behaviour (Millett, 1971, p. 31). Money and Tucker thus claimed that "the test girls take it for granted that they will eventually marry and have children", but show no more interest in "weddings and babies" than girls in the control group (Money \& Tucker, 1975, pp. 70-71). On the other hand prenatally underandrogenised boys were noted to be "quieter than most boys" and "less inclined to join in competitive sports" despite their "masculine" upbringings (ibid., p. 71). Money and Tucker's claim also suggests a behavioural double-standard: girls who are assertive have been considered to be "bitches" (CrannyFrancis et al., 2003, p. 146), whereas boys with this trait are considered to be "authoritative" (ibid., p. 145).

In Man \& Woman, Boy \& Girl (1972) Money and Anke A Ehrhardt defined hermaphroditism as improper differentiation of the sexual anatomy - in other words a neonate is "sexually unfinished" (Money \& Ehrhardt, 1972, p. 5). They argued that development of gender identity differentiation is influenced by parents' "responses" to a child's external genitals: that "dimorphism of response on the basis of the shape of the sex organs" reinforces a child's "gender-dimorphic behaviour" (ibid., pp. 11-12). Money asserted that ambiguous genitalia "tell[s] a lie to their owner" with regard to their gender role and identity (Money, 1963, p. 56). He therefore recommended "early and cosmetically good corrective surgery" as, he claimed, genital appearance "tells the parents and the child in no uncertain terms that he or she is a boy or a girl" (Harlow, c1977, pp. 25-26). He warned that if clinicians "fail to schedule first-stage corrective genital surgery" their "uncertainty" will spread quickly to the parents and then “contagiously" to the child (ibid., p. 25-26). Money and Ehrhardt also warned that 
"[r]elatives and babysitters are equally nonplussed and, moreover, gossipy" (Money \& Ehrhardt, 1972, p. 152).

Money's argument that early genital surgery eliminates "uncertainty" influenced the construction of intersexuality as a pathological condition, because of social (not health) concerns about ambiguity. This is evident in Matthews' argument about society's "gender order" (Matthews, 1984, p. 13) in which medical institutions deal with individuals whose sexual anatomy, through no fault of their own, "deviate" against twosex biological norms. I would further argue that advances in surgical techniques during the latter part of the 20th century were another influencing factor together with Money's "proof" of his theory from case studies. This is regarding Grumbach's recollection of Money preaching his gender theory at a conference, which convinced clinicians that they could "really do anything" such as changing a child with an XY (male) karyotype into a female (Grumbach; in Colapinto, 2000, p. 76).

Despite Money's claim that gender identity is malleable at birth, he warned that clinicians "must be very careful about forced assignment" as children become very familiar with "the concept of 'he' or 'she", particularly on those whose identities are clearly male or female (Harlow, c1977, p. 26). Money and Ehrhardt advised that the age cut-off point for sex reassignment should be 18 months as a child's gender identity is "already well advanced in its differentiation" (Money \& Ehrhardt, 1972, pp. 13, 125). $\mathrm{He}$ and the Hampsons asserted that, once children reach the age of two and a half years, it is "too late" to impose a change of sex assignment as gender role "is so well established" (Money, Hampson \& Hampson, 1955, pp. 289-290). Money argued that for "successful assignment of a genetic male as a girl" a child's gender identity will differentiate from "the experiences of rearing" (Money, 1975, p. 66). Another factor for female instead of male assignment, he said, was that a vaginoplasty procedure "requires only two surgical admissions" whereas a phalloplasty procedure required "as many as a dozen or more" (ibid., p. 66). He advised that motherhood can be achieved via adoption so that the female-reared individual "does not feel like a freak" (ibid., p. 66). Money also advised oestrogen therapy so that a girl will not only mature sexually at puberty but, if she has a uterus, have periods induced so she will feel feminine: 
Menstruation is so strong and valued a symbol of femininity that a girl does not want to be denied the experience... Even later in life the symbol retains its strength so that very few patients elect against cyclic therapy and in favour of the convenience of no periods.

(Money, 1961, p. 483).

A gender meaning emerges from Money's advice about hormonally inducing menstruation - that menstruation is essential for a girl's femininity, and in turn a gender stereotype that all pubescent girls menstruate. Money's advice that male and femaleassigned children should be reared differently, based on genital and reproductive differences, not only shows the oppressiveness of gender stereotypes ("the cult of the 1950s housewife", for example) but that they fail - as proven by the well-known "twins case".

\section{"Nature versus nurture" and "the twins case"}

The "twins case" refers to a set of phenotypically male twins born in Canada in 1965 Bruce (later David) and Brian Reimer. ${ }^{27}$ The case had a profound influence on clinical practice in specialties such as paediatric endocrinology (Colapinto, 2000, p. 39).

Grumbach remarks that the case confirmed and accepted "the theory that human beings are psychosexually malleable at birth" with regard to managing children born with ambiguous or injured genitalia (ibid., p. 75). He also recalls a time when Money spoke at a conference about the twins: that "one of them is now a girl, and the other is a boy" (Grumbach; in ibid., p. 76). Grumbach recalled that Money's words were "really powerful", referring to the notion that doctors "can really do anything" such as changing a "normal XY male" neonate into a female, and that "John Money is a major figure, and what he says gets handed down and accepted as gospel by some" (ibid., p. 76). Indeed, a New York City-based endocrinologist, whom Kessler interviewed in 1985, considered that clinicians "have been raised in the Money theory" (Kessler, 2001, pp. 161-163). These comments by clinicians are similar to Judith Butler's postmodern theoretical argument about the power of language. Butler argues that, when repeated, language has the ability to become "entrenched practices and, ultimately, institutions" (Butler, 1990, pp. 147-148).

\footnotetext{
${ }^{27}$ In various publications Money referred to the twins as "John/Joan", pseudonyms taken from John and Joan Hampson, two married psychiatrists whom Money worked with at Johns Hopkins during the 1950s (Colapinto, 2000, pp. xv, 31-32). David Reimer agreed to reveal his true identity in Colapinto's (2000) book (ibid., pp. xvi-xvii).
} 
Money claimed that the "effects of emphasising feminine clothing became clearly noticeable in the girl's [Brenda] attitude towards clothes and hairdo" (Money, 1975, pp. 66-67) and that she preferred being "neat" and "disliked to be dirty" in contrast with her brother (ibid., p. 67). He also claimed differences in rearing regarding domestic activities (ibid., p. 69). The mother reported that her "daughter" copied her doing housework - an activity "traditionally seen as part of the female's role" (ibid., p. 69) while the boy (David's brother Brian) "could not care less about it” (ibid., pp. 69-70).

At eight months of age Bruce lost his penis in a circumcision accident (Colapinto, 2000, pp. 11-15). In 1967 the twins' parents, Ron and Janet Reimer, met with Money who advised that Bruce could be reassigned as a girl - which included having "a perfectly functional vagina" created - and that "she would develop psychologically as a woman and would find her erotic attraction to men" (ibid., pp. 49-50). Journalist John Colapinto remarks that it is unclear if $\mathrm{Mr}$ and Mrs Reimer understood that such management "was in fact purely experimental": that while Money and his colleagues at Johns Hopkins had managed reassignments on intersex children, no such reassignment had ever been managed on a "normal child" (ibid., p. 50). As "planned experiments" on humans were deemed unethical ${ }^{28}$, Money seized on an opportunity (ibid., p. 67) to prove "that boys and girls are made, not born" (ibid., p. 69) with a set of identical twins - "the ultimate matched pair" (ibid., p. 68). On Money's advice, at 22 months of age Brenda (as Bruce was renamed) underwent an orchidectomy performed by Dr Howard Jones ${ }^{29}$, who commented that Brenda's surgery was akin to the "routine castrations" he had previously performed on intersex infants (ibid., p. 53).

On 28 December 1972 Money presented his research on the twins at the annual meeting of the American Association for the Advancement of Science (AAAS) in Washington DC (ibid., p. 65). Money's presentation, which coincided with the publication of Man \& Woman, Boy \& Girl (1972), co-written with Anke Ehrhardt, outlined his theory on gender: "that the primary factors driving human psychosexual differentiation are learning and environment, not biology" (ibid., pp. 65-66). In order to support this

\footnotetext{
${ }^{28}$ In 1998 Colapinto was informed by spokesperson JoAnne Rodgers that during the 1960s all surgeries considered to be experimental had to be approved by "appropriate committees and boards" (ibid., p. 53). ${ }^{29}$ With regard to the previous footnote, Jones "cannot recall that the hospital convened any special committee or board in the case of Bruce Reimer's historic conversion to girlhood” (ibid., p. 53).
} 
argument Money outlined other research undertaken with "matched pairs" of intersex people and claimed that, while sharing a similar condition, they had been "successfully" brought up "as opposite sexes" (ibid., pp. 66-67). Money claimed his experiment with the twins was "an unqualified success" (ibid., p. 68): that Bruce - now renamed Brenda - was a "remarkable" contrast to "her twin brother Brian", and talked about Brenda's interest in dolls and kitchen work compared to her brother's interest in cars and tools (ibid., p. 69).

It could be argued that Money's claim of "successful" rearing as male or female, in "matched pairs" and the twins, had a profound influence on medicine's rationale for "recommended gender assignment". When considering Grumbach's comments that Money's words were powerful (Grumbach; in ibid., p. 76), one can imagine specialist clinicians attending the AAAS meeting 40 years earlier listening to Money speak and believing (albeit feeling excited) that a child born physically male really can be "made" (via surgery and rearing) to think she is a girl. With regard to Butler's argument about language's ability to "become entrenched practices" (Butler, 1990, pp. 147-148), one can imagine the clinicians who attended the AAAS meeting informing their colleagues at hospitals and medical schools about Money's authoritative research on intersexuality and gender identity: they in turn spread Money's "powerful" words on the subject to other colleagues.

The twins case, and Money's other research from the 1950s, also influenced second wave feminist arguments about biological differences between men and women. In Sexual Politics (1972), Kate Millett drew from Money's research in the 1950s on the "psychosexual neutrality" of neonates, and argued that Money's work was "scientific proof" that differences between men and women are not based on biological traits but because of "societal expectations and prejudices" (Millett, 1971, pp. 30-31). Indeed, in 1973 (one week after the AAAS meeting) Time magazine reported that the twins case “provides strong support” for women's liberation (in Colapinto, 2000, p. 69). The twins case, and Money's other work on the essentiality of gender stereotypes for humanity's survival (Money \& Tucker, 1975, p. 38), appear to have influenced clinicians for decades. Recent medical management of intersexuality (as discussed in chapter 9) appears to be based on biological factors such as a uterus - hence female sex assignment 
based on the stereotype that females reproduce. As will be discussed in chapter 6, medical advice on rearing as male or female implies that male- or female-assigned children should be treated differently in accordance with societal constructions of gender based on biology. For example, a child might be discouraged from playing rugby or wanting to become a mechanic as this would not conform to societal expectations (stereotypes) of femininity.

In 1980, on finally learning the truth about the botched circumcision (Colapinto, 2000, pp. 179-180), Brenda immediately began to identify as male and was renamed David as he disliked his birth name Bruce (ibid., pp. 181-182). That same year David commenced testosterone administration and underwent a double mastectomy (ibid., p. 183), his breasts being a consequence of oestrogen administration advised by Money three years earlier (ibid., pp. 129, 131). Sadly, his brother Brian died of a drug overdose in 2002 and David committed suicide in 2004 (Reimer (Obituary), Telegraph, 2004). The twins case appears to be akin to the experiences of many individuals with androgen insensitivity syndrome (AIS) (see chapter 7). Like David Reimer, many AIS individuals had their testes removed because, in accordance with societal prejudices, these male sex organs contradicted their female assignment - the notion that women do not have testes. Like David Reimer (Colapinto, 2000, pp. 129, 131), they were administered oestrogen during early adolescence to develop breasts because, it could be argued, Western societal expectations associate breasts with "normal women".

Despite being proven wrong by Reimer, Money refused to accept that his "experiment" with the twins had failed. Following an approach by a BBC film crew in 1979, who advised Money that they had heard differing opinions about the twins case (ibid., p. 171172), Money went from becoming silent about the case in publications (ibid., p. 200) to claiming that it was "lost to follow-up" (ibid., p. 202). However, Money's power and influence prevented Canadian psychiatrist Keith Sigmundson from publishing the truth about Reimer's rejection of his female assignment (ibid., p. 199). Sigmundson remarks that, as well as being frightened of Money himself, he was frightened that publishing an article would affect his career (ibid., p. 199). Howard Devore, a psychologist whose doctorate was supervised by Money during the 1980s, kept his intersex condition and arguments against his childhood "normalising" surgeries (and consequent psychological 
trauma) from his then supervisor (ibid., pp. 219-220). Devore recalled that Money was a "very, very angry man" who would "make you feel horrible for challenging him" (ibid., pp. 219-220). Following the publication of Milton Diamond's and Sigmundson's article $^{30}$ that revealed the real outcome of the twins case (ibid., p. 211), Colapinto recalled that Money became "angry" when asked about Diamond's advice to delay surgery until intersex people are old enough to give consent (ibid., p. 247). Money asserted that delaying surgery would jeopardise a child's "future happiness", and that Diamond's and Sigmundson's guidelines would regress intersex people "to the days when they locked themselves away in shame and worked as "circus freaks"' (ibid., p. 248).

Five years after Money claimed that stereotypical activities such as housework successfully integrated the female-assigned twin into "her" gender role, David Reimer (as he renamed himself) announced that he would live as a male. Furthermore, Brenda (as David was then) disliked stereotypically feminine activities such as playing with dolls, despite her mother's attempts to "teach her to want to be a girl” (ibid., p. 56). These issues are further discussed in chapter 7, which analyses the ways in which one intersex person (Tony Briffa) talks about his luridly stereotypical female upbringing as a dismal failure. This is highlighted by his insistence that he was "a boy" and, like Reimer, wanted to live as a male (Bragge, 2005).

Parallels relating to issues of power also emerge between Money's "experiment" and the one at National Women's Hospital, Auckland, which was initiated by Herbert Green. While then doctoral student, Devore refrained from challenging Money's arguments for fear of incurring Money’s wrath, a powerful medical hierarchy (Jones, 2009, pp. 7374) was one aspect that made people reluctant to raise concerns about the "experiment" at National Women's Hospital. Another parallel is that, while Sigmundson's fear of Money prevented him from publishing an article revealing the truth, after the Cervical Cancer Inquiry was announced, Jones faced hostility from many of his medical colleagues (ibid., p. 88). And while Money remained in denial about his "experiment" being a failure, some continue to argue against the Cartwright Report's findings (ibid.,

\footnotetext{
${ }^{30}$ Diamond, M., \& Sigmundson, H. K. (1997). Sex reassignment at birth: long-term review and clinical implications. Archives of Pediatrics and Adolescent Medicine, (151), 298-204.
} 
p. 71). If it was not for the courage of individuals such as Diamond, Sigmundson, Coney and Bunkle, who challenged powerful and influential institutions for the sake of New Zealand women and intersex people, the realities of Money's and Green's experiments may have remained unchallenged and in silence.

\section{Conclusions}

From these findings, a difference in medical practice and approach emerged between the early and latter halves of the 20th century. Young, who practiced during an earlier time period (notably 1920s-1930s) than Money (notably 1950s-1970s), appeared to acknowledge that surgery was not going to guarantee a female gender identity. Hirschfeld, who undertook research and published work at an even earlier time period (1890s-1930s), also acknowledged gender fluidity. In contrast, Money refused to acknowledge that Brenda Reimer, whom he claimed had been successfully reassigned as a girl, had renamed himself David and had completely rejected his female assignment. While Money argued that gender identity can be enforced by rearing ("nurture over nature"), Hirschfeld asserted that the identity or appearance of men as more feminine and vice versa resulted from their anatomical constitutions. Furthermore, Hirschfeld suggested that intersex anatomy is healthy based on his assertion that everyone (intersex or not) retains traces of intersexuality till death (Hirschfeld, 1919, p. 432).

From this chapter's findings I argue that, if the male pseudohermaphrodite (Young's case) was born during the second half of the 20th century, the individual's experience may have been less positive as Money's influence had by then taken a stronghold on clinical practice. Hirschfeld's and Young's acknowledgement that an individual's gender identity may change over time, and may be separate from their sexual anatomy, resembles third wave feminist and queer theorising about bodies and identities which are discussed in chapter 6. Feminine gender stereotypes, which Money argued were necessary for a society, are also discussed from second wave theoretical positions in chapter 6. 


\section{Chapter 5:}

\section{The scientific basis of sexual differentiation}

While this chapter mostly describes the scientific basis of intersexuality, I will discuss how medical responses to intersex conditions are not only anatomical descriptions but can also be based on social and cultural considerations. Such considerations particularly relate to medical recommendations for male or female sex assignment, such as a traditional generalisation that all women want to have children. I will first outline typical sexual differentiation, beginning from a single cell secreted by an ovary in the fallopian tube through to a foetus' 14th week. I have adopted Diamond and Sigmundson's (1997, p. 1046) use of "typical" instead of "normal". Next, I will outline medical explanations for specific intersex conditions, particularly where "recommended gender assignment" and health concerns are noted in medical texts. I will discuss some of these findings with regard to theories about sex and gender (in chapter 6) and published intersex people's experiences (in chapter 7).

\section{Typical sexual development}

Paediatric endocrinologist Charmian A Quigley and human genetics professor Eric Vilain remark that sex determination and sex differentiation are distinct terms. Sex determination (also called primary sex differentiation) occurs during the development of the gonads whereas sex differentiation (also called secondary sex differentiation) occurs during the development of the internal and external genitalia (Quigley \& Vilain, 2010, p. 2148). In a typical cell humans have 46 chromosomes of which 22 pairs are autosomes (non-sex chromosomes), while the 45th and 46th (the 23rd pair) are known as the "sex chromosomes" - XX ("normal female") or XY ("normal male") (Hamilton \& Wynshaw-Boris, 2004, pp. 7, 13). Chromosomes contain 30,000 to 40,000 coding genes (ibid, p. 7). The autosome pairs are numbered from the largest - the first pair, "1" - to the smallest - the 21st and 22nd pair, "21 and 22" (ibid., p. 7).

Genetic sex (an XX or XY karyotype) is established when fertilisation occurs (Cunningham, Leveno..., \& Wenstrom, 2005, p. 112), when a single spermatozoon 
sperm) fertilises an ovum $^{31}$ (egg), released from an ovary during ovulation, in the fallopian tube of a woman. The sperm then penetrates the outer covering of the egg, where the egg's 23 chromosomes fuse with the sperm's same number of chromosomes to form the 46 chromosomes of the developing embryo - eggs provide an X sex chromosome while the sperm provides an X or Y sex chromosome (Pullon \& Benn, 2008, p. 60). It is generally noted that fertilisation can only occur for a few hours and no more than one day after the ovum has been released from the ovary (Cunningham et al., 2005, p. 52). Thus spermatozoa must be present in the fallopian tube at the time of ovulation: "almost all" pregnancies occur when coitus occurs within two days prior to or on the day of ovulation (ibid.).

After fertilisation the ovum becomes a zygote (a diploid cell with 46 chromosomes) which then divides into two, then four and then eight blastomeres (cells within the zygote) (Cunningham et al., 2005, p. 52). The blastomeres continue to divide and form the morula which resembles a solid ball of cells (ibid., pp. 52-53). About three days after fertilisation the morula enters the uterus and accumulates fluid to form a blastocyst, so that the ball-like structure comprises a surface layer of cells with a fluid centre and inner cell mass (ibid., pp. 52-53). Four to five days after fertilisation, in a 58-cell blastocyst five cells differentiate into the inner cell mass which becomes the embryo, while the 53 remaining cells become trophoblasts (ibid. p. 52). Six to seven days after fertilisation, the embryo implants into the endometrium (wall) of the uterus (ibid. p. 52). At this time the blastocyst now comprises 100 to 250 cells (ibid., p. 52).

The development of testes in a male embryo is influenced by the testis-determining factor (TDF), a gene located on the short arm of the $\mathrm{Y}$ chromosome, which is also known as the sex-determining region (SRY) (ibid., p. 112). The development of testes is also influenced by a dose-dependent sex reversal (DDS) region located on the $\mathrm{X}$ chromosome (ibid., p. 113). During the fifth and sixth weeks of gestation the gonad (which develops into an ovary or testis) comprises of an outer cortex and an inner medulla - at this time there is "no morphologic [sex] difference" between the gonads (Quigley \& Vilain, 2010, p. 2149). The gonads then begin to differentiate when germ

\footnotetext{
${ }^{31}$ An ovum is distinct from an oocyte. An oocyte is a cell in the ovary which undergoes meiosis (cell division) to form a secondary oocyte, which then becomes a mature ovum (Oxford, 2003, p. 485).
} 
cells $^{32}$ arrive (ibid, p. 2149). In foetuses with a 46,XX (female) karyotype the cortex develops "under the influence of the germ cell lineage" while the medulla regresses, so that the gonad becomes an ovary (ibid., p. 2149). In foetuses with a 46,XY (male) karyotype the medulla develops so that the gonad becomes a testis (ibid., p. 2149).

In the female foetus during the ninth and 13th week of gestation, the wolffian ducts regress and upper portions of the müllerian ducts develop into the fallopian tubes, while the lower portions of the müllerian ducts - already fused in a " $\mathrm{V}$ " shape during the "indifferent stage" - develop into the uterus, cervix and upper part of the vagina (ibid., p. 2151). In the male foetus during the eight and 13th week of gestation the wolffian ducts develop, with the influence of testosterone, into the epididymis, vas deferens and seminal vessels, while the müllerian ducts have regressed completely by the 11th week of gestation (ibid., p. 2151. Müllerian duct regression in the male foetus is influenced by an anti-müllerian hormone (AMH) secreted by sertoli cells, which are found in the testis (ibid., p. 2151).

Leon Speroff and Marc A Fritz state that the embryo's brain is possibly “sexually differentiated" by an influence similar to what determines the development of the external genitalia (Speroff \& Fritz, 2005, pp. 328-329). They refer to a study conducted by Berenbaum and Bailey (2003, p. 1102) which is outlined later in this chapter. As outlined in chapter 4, Money also claimed that prenatal hormones have an effect on "male/female dimorphism of the brain" (Money, 1987, p. 384). Speroff and Fritz comment on androgen exposure during the ninth to 14th week of gestation. As well as causing varying ambiguous genitalia in female phenotypes (such as clitoral enlargement and scrotalisation of a non-fused labia), they say that there is "experimental and analytical evidence" that "sufficient amounts" of androgens during development of the central nervous system (CNS) can "induce patterns of male sexual behaviour" therefore "foetal hormonal programming" during prenatal development influences varying degrees of “psychosexual behaviour” (Speroff \& Fritz, 2005, pp. 328-329).

\footnotetext{
${ }^{32}$ Germ cells (also called gonocytes): embryonic cells that potentially develop into spermatozoa or ova (egg cells). The term is also applied to gametes (mature sex cells - sperm or eggs) and cells undergoing gametogenesis (process when eggs and sperm are formed). Gametes contain 23 chromosomes instead of 46 (ibid.; pp. 275, 283, 499).
} 
In my view the belief about masculine-type behaviour being caused by biological factors (such as androgens) is based on societal expectations of gender stereotypical behaviour. With regard to Millett's (1971, p. 31) argument about culture, I suggest that researchers such as Berenbaum, Bailey and Money may have taken particular notice of "tomboyish" behaviour in girls because of their mere classification as girls. According to societal stereotypes that Money advocated (in chapter 4), behavioural traits such as aggressiveness and interest in rough play are regarded as unusual in a girl and interpreted as masculine. Because these traits "deviate" (Matthews, 1984, p. 20) from typical behaviour expected in phenotypical females, I argue that medical perspectives tend to focus on biological determinist claims (the effects of androgens on the brain during prenatal development, for example). One can imagine a biological determinist perspective on phenotypical male children with a keen interest in ballet and cooking: that, as these interests could be regarded as feminine, these behavioural traits suggest a cause of oestrogens on the brain during prenatal development!

Puberty, when children reach sexual maturity, consists of "inter-related endocrine and physiologic changes" in an individual, that Emeritus Professor of Medicine and Physiology William D Odell describes as "transform[ing] a sexually immature individual to a sexually mature one capable of reproduction" (Odell, 2001, p. 1955). In boys, testosterone causes the larynx to increase in size, thus causing the voice to deepen (ibid., p. 1961). Testosterone also causes the bones to increase in mass, an increase in muscle strength (resulting in a "growth spurt"), the skin to thicken and an increase of hair "on the trunk in the pubic and axillary [armpit] areas and on the face" (ibid., p. 1961). Odell also states that behaviour changes "as testosterone or oestradiol ${ }^{33}$ produced from testosterone in the nervous system stimulates sexual libido and aggressiveness" (ibid., p. 1961). In girls, androgens secreted by the adrenal glands are "a major cause of the development of axillary [armpit] and pubic hair growth in females" (ibid., p. 1961). Oestradiol and progesterone, secreted by the ovaries, cause breast development, distribution of body fat, and changes in vaginal and uterine tissues and secretions (ibid., pp. 1961-1962). When girls begin menstruating (menarche) one or

\footnotetext{
${ }^{33}$ Oestradiol: "the major female sex hormone" secreted by the ovaries. Other female steroid hormones include oestrogens, also secreted by the ovaries and in lesser amounts by the adrenal cortex, testes and placenta. Excessive oestrogen secretion in "normal males" thus causes feminisation (ibid., p. 481).
} 
two primary oocytes (first egg cells) begin to develop each month, which undergo meiosis (cell division) and oogenesis ${ }^{34}$ to create one ovum (egg) per oocyte (Maxson \& Daugherty, 1989, p. 118). The ovum (fertilised or not) travels along the fallopian tube and enters the uterus. In the case of an unfertilised ovum, the uterus sheds its lining (the endometrium) about once every 28 days which becomes menstrual flow (ibid., p. 120).

Odell's comments about hormonal changes between boys and girls may explain Viloria's (2011) perception (in chapter 7) about differences in hormone administration for intersex children: oestrogen for girls to develop "feminine" bodies and testosterone for boys to develop "masculine" ones. Odell's comment that testosterone causes aggressiveness reinforces gender stereotypes - the belief that certain behavioural traits are influenced by biological factors, as argued by Millett (1971, p. 31) in chapter 4. Odell's comment thus resonates with Millett's (ibid., p. 31) argument about societal culture where behavioural traits such as aggressiveness are expected in males, whereas females displaying such traits would be regarded as "bitches" (Cranny-Francis et al., 2003, p. 146).

\section{Differences of sexual development (DSDs)}

I have deliberately used the term "differences" instead of "disorders" when referring to DSDs in full. Like intersex activists David Cameron, Peter Trinkl and Esther Morris Leidolf (Intersex Society of North America, 2006, p. ii), I dislike the term "disorder" when referring to intersex variations. However, I believe that "disorder" should apply to a health- or life-threatening condition that requires urgent medical attention: for example, an "adrenal disorder" when talking about congenital lipoid adrenal hyperplasia - the most serious salt-wasting form of CAH (Forest, 2001, p. 1987). Congenital lipoid adrenal hyperplasia (also called Prader's syndrome, commonly referred to as lipoid $\mathrm{CAH}$ ) results from a defect in the mitochondrial enzyme P450scc $(\mathrm{scc}=$ cholesterol side $c$ hain $c$ leavage - see diagram on page 83$)$ which is encoded in the testis and adrenal gland (ibid., p. 1987). This enzyme defect causes the gonad and adrenal cortex to fail to produce a steroid compound necessary to convert cholesterol to

\footnotetext{
${ }^{34}$ Oogenesis: production of mature ova (egg cells) in the ovary (ibid., p. 485).
} 
pregnenolone $^{35}$ (ibid., p. 1987). After a few days or weeks after birth individuals display symptoms of complete adrenal deficiency - vomiting, diarrhoea, weight loss, skin pigmentation and urinary salt loss (ibid., p. 1987) - and only 11 out of 35 affected individuals have survived infancy (ibid., p. 1988). However, with appropriate glucocorticoid $^{36}$ and mineralcorticoid ${ }^{37}$ therapy, Maguelone G Forest says that "long survival is possible" (ibid., p. 1988). Other less serious types of CAH are outlined later in this chapter.

\section{Disrupted development of the primordia ${ }^{38}$ gonad}

Individuals with disrupted development of the primordial gonad have "gonadal dysgenesis" and can present with female-appearing or ambiguous genitalia. Gonadal dysgenesis can have many different causes and associated features, such as degenerative kidney disease in Denys-Drash syndrome (DDS) ${ }^{39}$ due to disruption of the WT-1 gene (Forest, 2001, p. 1975). Another form of gonadal dysgenesis that can affect the gonad and adrenal gland is caused by a "mutation in the gene-encoding steroidogenic factor-1 (SF-1)" and the first such case was reported by endocrinologists John C Acherman, Masafumi Ito, Mika Ito, Peter C Hindmarsh and J Larry Jameson in 1999 (Acherman, Ito..., \& Jameson, 1999, p. 125). The individual was a phenotypical female with an XY karyotype, who presented with primary adrenal failure during the first two weeks of her life (Achermann et al., 1999, p. 125). A presumed diagnosis of lipoid CAH was made, and at the age of 10 an examination of her hormonal status revealed no testosterone response (ibid., p. 125). A laparotomy revealed streak gonads and "normal" müllerian structures, and transdermal $17 \beta^{40}$-oestradiol (female sex hormone) gel induced breast

\footnotetext{
${ }^{35}$ pregnenolone: a steroid found in the ovaries, testes and adrenal glands. Depending on the pathways (synthesis), pregnenolone can be converted to corticosteroids (glucocorticoids or mineralcorticoids), androgens or oestrogen (ibid., p. 555)

${ }^{36}$ glucocorticoids: a group of hormones which enables the body to utilise carbohydrate, fat and protein, especially when the body reacts to stress. "Glucocorticoids occur naturally but can be synthesized" (Black, 2004; pp. 143, 261).

${ }^{37}$ mineralcorticoids: as per previous footnote (ibid., p. 407).

${ }^{38}$ Primordial (adj): describing formation of cells or tissues during the early stages of embryonic development (Oxford, 2003, p. 558).

${ }^{39}$ Denys-Drash Syndrome (DDS) is characterised by three distinct symptoms: "abnormal" genitalia, nephropathy (disease of the kidneys) and Wilms' tumour - a malignancy of the kidneys. DDS results from a mutation of the Wilms' tumour suppressor gene (WT1) located on chromosome 11p13 (Forest, 2001, p. 1976).

${ }^{40}$ The $17 \beta$-hydroxysteroid dehydrogenase (17 $\beta$-HSD) enzyme is illustrated in the diagram on page 83.
} 
development (ibid., p. 125). Growth of her uterus and regular periods were induced by cyclical progestogen administration (ibid., p. 125).

The subject of Achermann et al.'s article was not asked directly if she wanted to have artificially-induced periods (J. Achermann, personal communication, 28 September 2012). She was, however, counselled by a specialist clinician "over a period of several months" that she would not undergo breast development and menarche naturally, and that these would need to be artificially induced (via administration of gel and progestogen tablets) if she wanted these to occur (ibid.). Achermann also remarks that not offering hormone replacement would not be considered in a child's best interests "because of the long term benefits of oestrogens", and that he and his colleagues aim to share information with children and their parents (ibid.). While Achermann and his colleagues recognise that oestrogen administration induces stereotypically feminine characteristics such as breasts, they also show concern about individuals' health in that oestrogen promotes bone mineral density. Their aim of sharing instead of withholding information from individuals also resonates with radical feminist health initiatives (Fee, 1978, pp. 286-288) about “feel[ing] in charge” of one's own body (Rakusen, 1981, p. 97).

\section{Gonadal dysgenesis}

Individuals with pure gonadal dysgenesis 46,XY (Swyer's syndrome) present with a "female phenotype, female internal genitalia, normal or tall stature and sexual infantilism with primary amenorrhoea [absence of periods at puberty]" (Forest, 2001, p. 1976). Other characteristics are a 46,XY (male) chromosome type, streak gonads which do not secrete testosterone or anti-müllerian hormones, a uterus and genitalia ranging from "ambiguous" to a "moderate[ly]" enlarged clitoris (ibid., p. 1977). Individuals with mixed gonadal dysgenesis (MGD) present with an "abnormal" testis on one side and "a rudimentary gonad, streak or no gonad at all" on the other side (ibid., p. 1977). Most MGD individuals have a "mosaic" 45,XO/46,XY karyotype (ibid., p. 1977). Some individuals also have a fallopian tube and uterus, while in other MGD individuals their müllerian ducts may regress and develop into a vas deferens (ibid., p. 1977). Forest recommends a diagnosis of "true hermaphroditism" and female rearing for MGD 
individuals as "surgical repair of the vagina is usually easy" and "a uterus or hemiuterus is present" (ibid., p. 1978).

Forest appears to advocate that a child should be reared according to a feminine culture and social environment (Millett, 1971, p. 31), merely because of biological factors such as a uterus. An essentialist theme also emerges from Forest's advice about female assignment: the essentialist criterion of a uterus and the possibility of a vagina via surgical repair. In turn, sex role stereotypes emerge from Forest's advice about rearing as female based on these anatomical characteristics. I would argue that identity is not essential (Cox et al., 1997, pp. 182, 191) as a child may cross gender boundaries by preferring stereotypically masculine activities and appearance - thus a child may fail gender training as female. Barbara Fried comments that the term "tomboy" refers to a "girl who behaves like a spirited or boisterous boy" (Fried, 1982, p. 47). She also argues that the term "tomboyism" marks such girls distinct from "normal" girls: it echoes societal "fears and disapproval" towards girls whose behaviour breaches what is considered "natural" (ibid., p. 47).

The term dysgenetic male pseudohermaphroditism is not a "distinct" diagnosis, but a “convenient" term used by D D Federman to classify 46,XY individuals presenting with symptoms such as bilateral dysgenetic testes (Forest, 2001, p. 1978). Individuals present with ambiguous genitalia, bilateral cryptorchidism (when testes fail to descend into the scrotum) or "rarely palpable" gonads, a urogenital sinus and a uterus (ibid., p. 1978). Forest advises that while "female gender assignment is usually preferred", male assignment may be more suitable for individuals with "extreme virilisation" and a descended testis (ibid., p. 1978). Forest advises that "[d]epending on the gender assigned" individuals "[sh]ould undergo hypospadias repair or feminising genitoplasty" surgery (ibid., p. 1978). Individuals with testicular regression have a 46,XY chromosome, and can present as "phenotypic[ical] females" with a "well-formed but hypoplastic [underdeveloped] uterus and well-formed [fallopian] tubes" (ibid. p. 1978). Individuals can also present as "phenotypic[ical] males" with congenital anorchia which is characterised by "normal male sexual differentiation" of internal and external genitalia but with a complete absence of testicular tissue (ibid., pp. 1978-1979). Forest states that individuals with testicular regression are "usually brought up as males" (ibid., 
p. 1979). Forest further recommends testosterone replacement therapy for a "normal pubertal and sexual life" and implantation of prosthetic testes for "cosmetic and, above all, psychologic [sic] benefit" (ibid., p. 1979). Again Forest, with regard to recommendations about male rearing, appears to advocate that children should be treated differently to female-assigned children, because of male biological factors such as testes. Forest's comment that children with this diagnosis are "usually brought up as males" is similar to Walter's observation about biological determinist arguments: the belief that boys, because of biological factors such testes and testosterone, "natural[ly]" prefer particular toys and interests (Cochrane, 2010).

Individuals with the condition 46,XX male (also called "sex reversal syndrome") have testicular development, XX chromosomes and no "normal" Y chromosome (Forest, 2001, p. 1980). 46,XX males have a "normal male" phenotype but at puberty 75 percent of 46,XX males develop gynaecomastia (breast development in males), "some degree of testosterone deficiency" and impaired spermatogenesis (production of sperm in the testis) (ibid.). From 1971 to 2001 approximately 200 cases have been reported, but it "would appear" that one in 20,000 to 30,000 males have this variation (ibid.). The occurrence is approximately 1 in every 100,000 individuals (Quigley, 2009).

Both X chromosomes are necessary for maintaining an ovary (Forest, 2001, p. 1981). "In females who only have one X, or deletions of the short or long arm of the X", the ovaries regress to streak gonads devoid of follicles which produce eggs (ibid., p. 1981). Individuals with Turner's syndrome (first described by American endocrinologist Henry H Turner in 1938) have a $45, \mathrm{XO}$ or $45, \mathrm{X} / 46, \mathrm{XX}$ "mosaic" chromosome type, gonadal dysgenesis (streak gonads), short stature and a webbed neck (ibid., pp. 1981-1982). Turner's syndrome appears in approximately one to 2500 live births (ibid., p. 1981), and three to eight percent of 45,XO and 12 to 21 percent of 45,X/46,XX individuals "may have normal [female] pubertal development and spontaneous menstrual periods" (ibid., p. 1983). Money and Patricia Tucker claimed that having undeveloped gonads will not prevent an individual with Turner's syndrome, who "always has a female body", from developing a "feminine gender identity/role" (Money \& Tucker, 1975, p. 50). Turner's syndrome individuals, Money and Tucker say, "are usually the epitome of conventional femininity": 
"They mother their dolls, adore babies, and take to homecraft like ducks to water... they are ideal homemakers and mothers of adopted children."

(Money \& Tucker, 1975, p. 50).

True hermaphrodites (Chase's diagnosis in chapter 7) are subclassified if their gonads are:

- lateral: when a testis is on one side and an ovary is on the other (frequently on the left side);

- $\quad$ bilateral: when the gonads have both ovarian and testicular tissue, known as ovotestes; and

- unilateral: when one gonad has both testicular and ovarian tissue, and the other gonad is either a testis or an ovary. A testis or ovotestis may be located "along the normal pathway of descent of a testis", but an ovary is nearly always in its usual position (Grumbach et al., 2003, p. 908-909).

True hermaphrodites, the rarest of intersex classifications, have been reported with a "normal female phenotype" and "normal male appearance with penile hypospadias" (Grumbach et al., 2003, p. 909). The variation was first described in 1899 and, as at 2001, approximately 400 cases have been reported since then (ibid., p. 909). "Male sex assignment" has been considered in true hermaphrodites presenting with "good phallic size, correctable hypospadias, and sufficient testicular tissue that could descend into the scrotum" (ibid., p. 909). However, Forest advises a "female sex rearing" if a uterus, vagina and "sufficient" ovarian tissue are found, as the descended gonads are at risk of becoming malignant (Forest, 2001, p. 1985). The most common chromosome type of true hermaphroditism is $46, \mathrm{XX}$, whereas $46, \mathrm{XX} / 46 \mathrm{XY}$ and $46, \mathrm{XY}$ types are rare (Grumbach et al., 2003, p. 909).

\section{Male pseudohermaphroditism - incomplete masculinisation of a genetic $(46, X Y)$ male}

Five enzymes are necessary in order to synthesise testosterone from cholesterol to produce masculine characteristics in boys (Forest, 2001, p. 1986). Male pseudohermaphroditism (“incomplete male sexual differentiation”) thus results from a 
deficiency in any one of the following five enzymes (the first four are illustrated in the diagram on the following page):

- $\quad 17 \alpha$-hydroxylase $(17 \alpha-\mathrm{OH})$

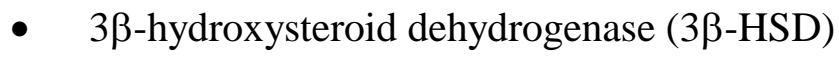

- 17,20-lyase

- $\quad 17 \beta$-hydroxysteroid dehydrogenase (17 $\beta$-HSD)

- 20,22-desmolase (ibid., p. 1986).

A deficiency in the enzymes 20,22-desmolase (which forms pregnenolone, a steroid found in the ovaries, testes and adrenal glands), $3 \beta$-hydroxysteroid dehydrogenase ( $3 \beta$ HSD) or $17 \alpha$-hydroxylase (17 $\alpha-\mathrm{OH})$ will result in CAH (ibid., p. 1986). A deficiency in the enzymes 17,20 -lyase or $17 \beta$-hydroxysteroid dehydrogenase (17 $\beta$-HSD) will only result in male pseudohermaphroditism (ibid., p. 1986). A health concern of the type of CAH associated with 3 $\beta$-HSD deficiency is salt loss during infancy (ibid., p. 1988), which can be life-threatening if enzyme blockage is severe, in which treatment includes administration of glucocorticoids and mineralcorticoids (ibid., p. 1989).

Individuals with $17 \alpha-\mathrm{OH}$ deficiency have the "rare form" of $\mathrm{CAH}$ which results in male pseudohermaphroditism in "genetic $[46, \mathrm{XY}]$ males" and sexual infantilism in "genetic females" $(46, \mathrm{XX})$. Forest remarks that most 46,XY individuals have been brought up as female "because they present with a complete female phenotype" (ibid., p. 1989). Individuals with $17 \beta$-HSD deficiency have a 46,XY chromosome type who present with "female external genitalia" and "male wolffian-duct derived internal genitalia", and "virilise extensively" at puberty "with or without gynaecomastia" (ibid., p. 1991). 17ßHSD individuals are "usually given a female sex assignment at birth" (ibid., p. 1992). However, in Arab populations in the Gaza strip (where occurrences of 17 $\beta$-HSD deficiency are more frequent) a "male" assignment has been recommended due to severe virilisation" at puberty (ibid., pp. 1991-1992). 


\section{Hormone conversion by enzymes in the adrenal gland}

Steroidogenic acute

regulatory $(\mathrm{StAR})$ protein

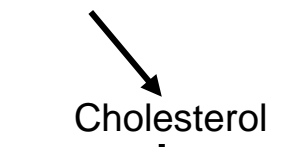

In the most common form of $\mathrm{CAH}$ there is a deficiency in the 21-OH enzyme, which results in impaired conversion of cortisol which in turn results in cortisol deficiency and "variable" mineralcorticoid deficiency. The "block" in two of the steroid conversion pathways (where the 21-OH enzyme is located) results in an excessive secretion of androgens (male hormones), so the baby will be born with masculinised genitalia.

\footnotetext{
P450scc

17a-hydroxylase/

Pregnenolone

17,20 lyase

$17 \alpha$-hydroxylase/
17,20 lyase

17-OH-pregnenolone

$3 \beta$-hydroxysteroid dehydrogenase $(3 \beta-\mathrm{HSD})$

3ß-hydroxysteroid

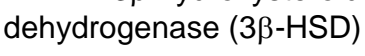

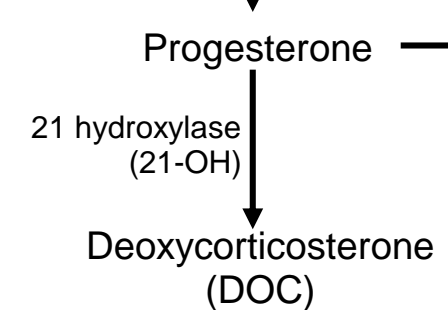

$11 \beta$-hydroxylase
$(11 \beta-\mathrm{OH})$

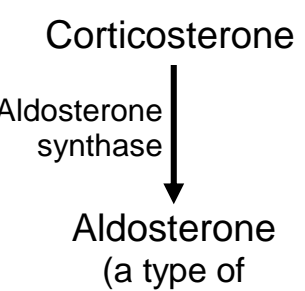

mineralcorticoid)

\section{7-OH-progesterone}

21 hydroxylase

$(21-\mathrm{OH})$

11-deoxycortisol

$11 \beta$-hydroxylase

$(11 \beta-\mathrm{OH})$

Cortisol

(a type of

glucocorticoid)

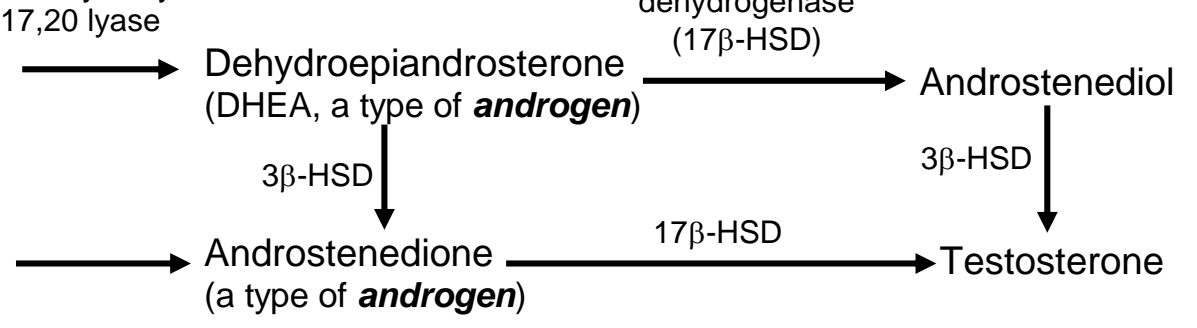

Deficiencies in the $\mathbf{3} \boldsymbol{\beta}-\boldsymbol{H} \boldsymbol{S} \boldsymbol{D}$ and $\mathbf{1 7} \boldsymbol{\beta}$-HSD enzymes will result in male pseudohermaphroditism (Forest, 2001, p. 1986).

The P450scc enzyme (shown at top left) is also located in the testis ( $s c c=$ cholesterol side $c$ hain $c$ leavage). A defect in this enzyme causes the gonad and adrenal gland to fail to convert cholesterol to pregnenolone, thus resulting in lipoid $\mathrm{CAH}$, the most serious salt-wasting form (Forest, 2001, pp. 1987-1988).

Mineralcorticoids and glucocorticoids are groups of hormones which enable the body to utilise carbohydrate, fat and protein, especially when the body reacts to stress.

"Glucocorticoids occur naturally but can be synthesized" (Black, 2004; pp. 143, 261). 
Health concerns of $17 \alpha-\mathrm{OH}$ deficiency are that individuals display hypertension (which may progress to kidney failure), hypokalaemic alkalosis ${ }^{41}$ and carbohydrate intolerance (ibid., pp. 1989-1990). Other conditions caused by reduced secretion of sex steroids are bone age retardation, osteoporosis and eunuchoidism ${ }^{42}$ (ibid., p. 1990). Treatment advised by Forest is glucocorticoid replacement therapy to suppress overproduction of $\mathrm{ACTH}^{43}$ - hence overproduction of mineralcorticoids which causes hypertension (ibid., p. 1990). Forest remarks that the outcome of treatment for $17 \alpha-\mathrm{OH}$ enzyme deficiency is better than other forms of CAH "because there is no risk of adrenal crisis" (ibid., p. 1990).

Individuals with $5 \alpha$-reductase deficiency (5-ARD) have a 46,XY chromosome type, "predominantly female" external genitalia and two testes (ibid., p. 1992). The role of $5 \alpha$-reductase is to convert testosterone to dihydrotestosterone (DHT), a "powerful" androgenic hormone present in peripheral tissue which masculinises a foetus' external genitalia during prenatal development, and causes the development of most male secondary sexual characteristics at puberty (Dorland, 2003, p. 519). Thus a "genetic (XY) male" with $5 \alpha$-reductase deficiency will be born with ambiguous genitalia (Wilson, 2004; Grumbach et al., 2003, pp. 952-953). Some 5-ARD individuals also present with hypospadias, micropenis or an enlarged clitoris (Forest, 2001, p. 1992). Forest remarks that most individuals have been reared as female but that puberty brings virilisation, phallic enlargement, descent of the testes into the scrotum and deepening of the voice (ibid., p. 1992). For individuals with an "unambiguous female gender identity" diagnosed later in life, Forest advises an orchidectomy with oestrogen administration at puberty, but then notes reports of individuals brought up as female who changed their "gender role behaviour" at adolescence (ibid., p. 1993). Testes are located in the labia, inguinal ${ }^{44}$ canal or abdomen in which sperm production and fertility

\footnotetext{
${ }^{41}$ Hypokalaemia: low levels of potassium in the blood, hypokalaemia occurs during dehydration. Alkalosis is a condition where the alkalinity of bodily fluids and tissues is abnormally high, alkalosis may be associated with loss of acid from vomiting (Dorland, 2007, pp. 19, 335-336).

${ }^{42}$ Eunuchoidism: decreased gonadal function in a male with deficiency in the testes or testicular secretions, and "deficient" secondary sexual characteristics (ibid., pp. 661, 915).

${ }^{43} \mathrm{ACTH}=\mathbf{a}$ drenocorticotropic $\mathbf{h}$ ormone, found in the anterior pituitary gland located beneath the hypothalamus at the base of the skull. During stress large amounts of ACTHs are released (Oxford, 2003, pp. 8, 537)

${ }^{44}$ Inguinal: "relating to or affecting the region of the groin (inguen)" (ibid., p. 351).
} 
- now possible with intrauterine insemination - has been reported (Diamond, 2007, pp. 3825-3826).

Individuals with the complete form of androgen insensitivity syndrome (CAIS) have a 46,XY chromosome type and testes (Quigley, 2009) present in either the labia, inguinal canal or abdomen (Diamond, 2007, p. 3823). On reaching puberty CAIS individuals have a "normal female" phenotype, developed breasts, small clitoris, sparse or absent pubic or underarm hair, a short and blind-ending vagina and primary amenorrhoea (when periods fail to appear at puberty) (Quigley, 2009). Because of their phenotype CAIS individuals are "always reared as girls" (ibid.). CAIS occurs in 1 in 20,000 to 1 in 60,000 individuals and is transmitted via a trait on the $\mathrm{X}$ chromosome (Diamond, 2007, p. 3824). Studies of testicular tissue in CAIS individuals show that the testes reveal "incomplete or absent spermatogenesis [production of sperm in the testis]" (ibid., p. 3824).

Newborn individuals with the incomplete (partial) form of AIS (PAIS - Briffa's correct diagnosis in chapter 7) present as a "phenotypic[al] male" with hypospadias, a small vaginal pouch and small testes (Forest, 2001, p. 1995). At puberty PAIS individuals "show some, but not complete, virilisation and develop gynaecomastia [male breast development]" (ibid., p. 1995). If the penis is "developed enough to allow corrective surgery" or responds to intra-muscular testosterone, and if the vaginal cavity is "too small" for feminising surgery, then Forest recommends a male assignment for PAIS individuals (ibid., p. 1995). However, if the phallus does not respond to androgen administration then rearing as female is recommended (ibid., p. 1995). Urologist David A Diamond, from Harvard Medical School and Children's Hospital in Boston, remarks that at puberty "[t]he phallus may enlarge slightly, but it remains small" and that testosterone administration has produced "disappointing" results (Diamond, 2007, p. 3825). A "classic phenotyp[ical]" trait of PAIS individuals is infertility (ibid., p. 3824). However, Diamond remarks that "phenotypic" traits such as azoospermia (absence of sperm in seminal fluid) vary amongst PAIS individuals (ibid., p. 3824), which suggests that fertility may be possible for some PAIS individuals. 
Parenthood may have therefore been possible for seMbessikwini (see chapter 7) if her testes had remained intact. Though she did not state whether she had PAIS or another condition, in my view clinicians should have allowed seMbessikwini to have a "chance" - however small - of "fathering a child" (seMbessikwini; in San Francisco Human Rights Commission, 2004). It is also interesting to note that many non-intersex individuals want children but have difficulty conceiving, and that their chances may be smaller than seMbesskwini or individuals with PAIS. Yet their genitals and internal sex organs remain intact because their bodies are regarded as "normal".

\section{Female pseudohermaphroditism - virilisation of a genetic $(46, X X)$ female}

Deficiencies in any of the following three enzymes (illustrated in the diagram on page 83 ) will result in CAH in "genetic $[46, \mathrm{XX}]$ females":

- 21-hydroxylase (21-OH)

- $\quad 11 \beta$-hydroxylase $(11 \beta-\mathrm{OH})$

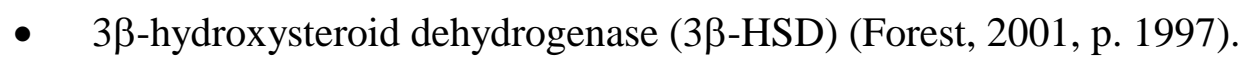

Individuals with 21-hydroxylase $(21-\mathrm{OH})$ deficiency have the most common form of CAH (referred to as "classic CAH") which results in a baby being born with varying degrees of virilisation with clitoral enlargement, an XX chromosome type and fusion of the labioscrotal folds (ibid., p. 1997). Forest advises that such individuals "should be brought up in her female gender" as they can have a "normal reproductive female life" and "appropriate plastic surgery" (ibid., p. 1997). Individuals with 11 $\beta$-hydroxylase (11 $\beta-\mathrm{OH})$ deficiency have the form of $\mathrm{CAH}$ associated with "severe virilisation", and

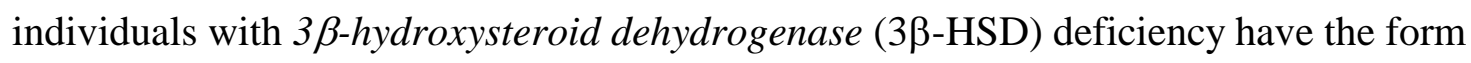
of CAH associated with "severe" but "minimal" virilisation (an enlarged clitoris and small labial fusion) (ibid., p. 1997). Forest advises an ultrasound examination to detect a uterus and ovaries to confirm a "correct female assignment" (ibid., p. 1997). Forest's advice that a child should be assigned female, because of reproductive characteristics such as a uterus, resonates with feminine gender role stereotypes that girls want to become mothers (Cranny-Francis et al., 2003, p. 143) 
Health concerns associated with 21-OH deficiency are that 50 percent of individuals experience salt loss in which Forest recommends glucocorticoid and mineralocorticoid replacement therapy (Forest, 2001, p. 1997). Symptoms of $11 \beta-\mathrm{OH}$ deficiency are saltretention, loss of potassium and hypertension (ibid., p. 1997). Forest remarks that adrenal crisis is rare as there is no symptom of salt loss, but that glucocorticoid deficiency can cause hypoglycaemia (glucose deficiency), and shock when the individual is stressed or having replacement therapy administered (ibid., p. 1997). Salt

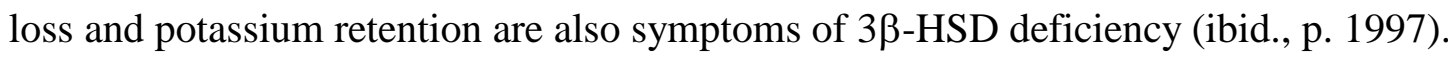

Speroff and Fritz claim that "some women [with CAH] report a decrease in heterosexual activity and an increase in homosexual activity", and comment that this finding is consistent with the belief that androgens during foetal development can affect sexual behaviour (Speroff \& Fritz, 2005, p. 336). A source of evidence was a study of gender identity conducted by Sheri A Berenbaum and J Michael Bailey, of Pennsylvania State University and Northwestern University (Illinois) respectively (Berenbaum \& Bailey, 2003, p. 1102). The study, to "address questions about sex assignment in children with ambiguous genitalia”, involved $43 \mathrm{CAH}$ girls aged three to 18 , as well as seven "tomboys" and 29 "sister control girls" (ibid., p. 1102). From their findings Berenbaum and Bailey claim that "moderate androgen excess early in development appears to produce a small increase in the risk of atypical gender identity" but that "this risk cannot be predicted from genital virilisation" (ibid., p. 1102).

Berenbaum and Bailey appear to pathologise homosexuality and gender fluidity as if they are bad traits, particularly when they talk about the latter as being a risk. Their findings also resonate with Walter's (Cochrane, 2010) observation of arguments about biological determinism: that androgens influence a child's preferences towards toys such as cars and guns. Berenbaum and Bailey's comment about "the risk of atypical gender identity" (own emphasis) also resonates with Matthews' argument about society's “gender order" (Matthews, 1984, p. 13) - particular with individuals assigned female. Like the psychiatrists at Glenside Hospital (ibid., p. 24), it appears that the aim of Berenbaum and Bailey's study was to establish a pathological cause (androgens during foetal development) for gender-“deviant” behaviour in female-assigned children. 


\section{Conclusions}

An essentialist theme emerges from medical advice about gender assignment: that in order to be classified as male or female, individuals must have physical properties such as "adequate" phallic size or a uterus and ovaries. This is indeed reflected by David Diamond's (2007, p. 3825) remark about "disappointing" results of testosterone administration on phallic growth, in determining whether a CAIS individual should be assigned male or female. Medical advice about clitoral reduction surgeries is also, I would argue, influenced by societal perceptions of physical normality. Though enlarged clitorises are not life-threatening, they imply the "cultural horror" of a "phallic female" (Harper, 2007, p. 95) in which, according to societal culture, a penis is an "exclusively male" (ibid., p. 77) property. This suggests that, though sexual ambiguity is not lifethreatening, some clinicians pathologise this as a treatable condition because of social concerns - the fear and uncertainty of "is it a boy or a girl?"

Some clinicians also appear to "police" sexual ambiguity as it disrupts constructions about masculinity and femininity (Duncan, 1997, pp. 128-129, 137). When societal constructions of a girl's "appropriate" behaviour (Matthews, 1984, p. 13) become disrupted by her "tomboyish" behaviour, some clinicians (Speroff \& Fritz, 2005, pp. 328-329) state that the cause is possibly biological - an excess of male hormones (androgens) on the brain during prenatal development. Theories about constructions of "good" femininity (Matthews, 1984, p.13), and disruptions (queering) of masculinity and femininity, are discussed in the next chapter. 


\section{Chapter 6: \\ Theoretical approaches to sex and gender}

I have used various feminist theoretical perspectives to analyse medical rationales for managing intersex conditions, and what various people's understandings are about medical procedures and gender.

I will discuss how each theorist informed my thinking about gender and medicine. From the works of three second wave feminist theorists (Germaine Greer, Kate Millett and Shulamith Firestone) I will discuss masculine and feminine gender stereotypes in response to my first research question, as it relates to my analysis of sex assignment based on anatomical characteristics such as uteruses (hence the stereotype that "all women want to have children"). While the works of Greer, Millett and Firestone may be regarded as dated as they were published 40 years ago, I will discuss how their arguments are still relevant with regard to the next sections about biological determinism and claims about "brain sex", and third wave feminism. I will then discuss how third wave feminism bridges opposing theories of the "women only"-centred second wave with more conceptual postfeminist strands such as postmodernism, which instead argues for gender fluidity. Using feminist poststructuralist theory I will discuss power structures wielded by the male/female binary code and societal pressures to conform to this, based on fears of harassment and prejudice, in relation to my third research question. With postmodern feminist theory I will discuss its perspective that gender is a concept formed by culture instead of biology - and the implications of this theory's aim to dismantle the male/female binary code. In response to my first and second research questions, with queer theory I will discuss gender fluidity and sexual ambiguity with regard to medical and societal notions of "normalisation".

\section{Second wave feminism - Greer, Millett and Firestone}

In The Female Eunuch (1970) Germaine Greer remarks that women lose their energy and ambition when they become castrated - hence a female eunuch - by patriarchy (Greer, 1970, p. 63). While I do not agree with Greer's arguments about AIS individuals in The Whole Woman (1999), her arguments about female gender stereotypes from her first book has informed my analysis of medical rationale for rearing 
as female. The very words "rearing as female" suggest sexist connotations in that female-assigned children should be treated differently from male-assigned children, as highlighted by Money's arguments for stereotypes when bringing up children (in chapter 4). In her discussion about female stereotypes, Greer argues that women are considered to be "more body than soul" and "more soul than mind" (ibid., p. 63) - thus the "essential quality" of a female stereotype is "castratedness" in which:

She absolutely must be young, her body hairless... and she must not have a sexual organ. No musculature must distort the smoothness of the lines of her body, although she may be painfully slender or warmly cuddly. Her expression must betray no hint of humour, curiosity or intelligence...

(Greer, 1970, p. 69).

Greer then expresses her anger on "failing" to live up to this stereotype:

I'm sick of pretending eternal youth. I'm sick of belying my own intelligence, my own will, my own sex. I'm sick at peering through the world through false eyelashes... I'm sick of being a transvestite. I refuse to be a female impersonator. I am a woman, not a castrate.

(Greer, 1970, p. 70).

In her chapter on "Energy", Greer discusses behavioural aspects associated with masculinity (such as ambition, motive and desire) which, she says, "convey marginal meanings which are incompatible with femininity" (ibid., pp. 76-78). Greer describes oppression against women students by the insistence of a passive sexual role - that female energy is deflected and perverted by "the denial of female sexuality" for "femininity or sexlessness" (ibid., pp. 76-78). On the other hand, male energy is formed differently to become aggression and competitiveness - thus the term female eunuch can be used to describe "the desexualisation of women" (ibid., pp. 76-78). Later, Greer notes that the foundation of Freud's theory of womanhood "is the masculine conviction that a woman is a castrated man" (ibid., p. 104). Greer's arguments about "castration" have influenced my thinking about female stereotypes because of two common medical recommendations that AIS individuals should be assigned "female" because of their "feminine" physical appearance, and that their testes should be removed to prevent male sexual characteristics during puberty. Her argument has therefore informed my analysis of whether the clinical management of AIS follows female stereotypical forms, in which "no musculature must distort the smoothness" (ibid., p. 69) of a "normal" female body. Indeed, Money uses the term "non-feminised eunuch" to warn how a male pseudohermaphrodite (which includes AIS individuals) will develop during adolescence 
if female hormones are not administered - that in the absence of testes female hormones cause the individual to experience "feminisation" during puberty (Money, 1986, pp. 172-173).

My thinking about masculine and feminine stereotypes, in relation to medical rationale for sex assignment and rearing, has also been informed by Kate Millett's arguments in Sexual Politics (1972). With regard to studies on intersex individuals by John Money and John and Joan Hampson, Millett remarks that "there is no [psychosexual] differentiation between the sexes at birth" in which "psychosexual personality is therefore postnatal and learned" (Millett, 1971, p. 30). She then cites Money's belief that gender is "first established "with the establishment of a native language"" (Money, 1965; in ibid., p. 31) and Jerome Kagin's studies on how children "of pre-speech age" are treated depending on their "sexual identity" - for example, "Hello, little fellow" and "Isn't she pretty" (Kagin, 1964; in ibid., p. 31). From these studies Millett argues that "male and female are really two cultures and their life experiences are utterly different", in which throughout childhood a child's social environment and culture provide "clues" on how "he or she must think and behave to attain or satisfy the demands" of one's gender assignment (ibid., p. 31).

Millett then remarks that a child undergoes "conditioning" where "temperamental differences between the sexes" are maintained: that culture "encourages" and "expects" male children to "develop aggressive impulses" but female children to "thwart her own or turn them inward" - thus this "process of reinforcement" causes girls to attain "the chief 'feminine' virtue of passivity" (ibid., p. 31). She also argues that culture maintains the belief that biological characteristics such as testes, penis and a scrotum contributes to aggressive traits in the male - for example, via "praising" comments such as "that guy has balls" (ibid., p. 31). Millett's argument about "male" biological characteristics is relevant to my analysis of "male assignment", on whether it is influenced by biological factors such as testes. On the other hand, it could be argued that medical rationale for removal of testes from a female-assigned child (as with AIS individuals outlined in chapter 7) is influenced by society's culture of gender - the expectation that "girls are not supposed have testes". 
In The Dialectic of Sex (1971) Shulamith Firestone (1945-2012) discusses "sex class": that "feminist revolution" requires an analysis of "the dynamics of sex war" and "the condition of women as an oppressed class" (Firestone, 1971, pp. 1-2). Firestone remarks that "biology itself - procreation - is at the origin of the dualism" (hence dialectic), thus "sex class sprang directly from a biological reality: men and women were created different, and not equally privileged" (ibid., pp. 1-2). She also argues that the "biological family is an inherently unequal power distribution": that before contraception women "were at the continual mercy of their biology" such as "constant painful childbirth" and breastfeeding which "made them dependent on males for survival", and that "the natural reproductive difference between the sexes led directly to the first division of labour at the origins of class" and created a "caste" model of “discrimination based on biological differences" (ibid., pp. 8-9). Firestone's arguments about biological differences have informed my argument that medical recommendations for male or female assignment - and male and female rearing - are based on biology. For example, I would argue that factors influencing female assignment are when an ultrasound scan reveals a uterus and ovaries, which indicates that such individuals are biologically capable of having children.

Drawing from the socialist ideology of Friedrich Engels and Karl Marx, Firestone argues that the elimination of "sexual classes requires the revolt of the underclass (women) and the seizure of control of reproduction", in which women would gain full control over their own bodies (ibid., pp. 10-11). Significantly, she argues that the "end goal of feminist revolution" is "not just the elimination of male privilege" but "sex distinction": that "genital differences between human beings would no longer matter culturally" (ibid., pp. 10-11). Firestone then argues that artificial reproduction would replace "one sex" reproducing "for the benefit of both", in which "children would be born to both sexes equally, or independently of either" (ibid., pp. 10-11). Hence, she remarks, the "tyranny of the biological family would be broken" (ibid., pp. 10-11). She later comments that radical feminism "is the second wave of the most important revolution in history", that "its aim" is to "overthrow... the oldest, most rigid class/caste system in existence, the class system based on sex" characterised by "archetypal male and female roles" (ibid., p. 15). Firestone's argument about "genital differences" is 
relevant to my first research question on medical rationales for managing intersex conditions, especially with regard to societal fears towards genital ambiguity.

My analysis of heterosexual assumptions has also been informed by Firestone's argument about artificial reproduction "for the benefit of both [sexes]", as highlighted by Eli seMbessikwini in the next chapter, who wished her testes had not been removed as she "wants very much" to father (not mother) a child (seMbessikwini; in SFHRC, 2004). Parenthood could have been achieved from spermatozoa obtained and then inseminated into her partner via artificial reproductive methods. Firestone's argument about the "tyranny of the biological family" has also informed my analysis of some medical assumptions (such as Money's in chapter 4) that male- or female-assigned children will want to "marry and have a family" with an "opposite sex" partner. With regard to Firestone's argument, it could be argued that some clinicians may not realise that male- or female-assigned children may later identify as gay men or lesbians who, via artificial reproductive methods, can and do have children like other gay and lesbian couples who do not have intersex conditions.

Despite being published 40 years ago, I would argue that Greer's and Millett's arguments about gender stereotypes, and Firestone's argument that women's oppression originates from a biological "sex class" (as sexist stereotypes), are relevant today. In New Zealand feminine stereotypes are evident in preparatory workshops for the Miss Wairarapa beauty pageant, where contestants spend time "learning how to sit, dress, walk and talk like a lady" (Macdonald, 2012, p. 8). While gender studies academic Annabel Cooper thinks that the "cultural fixation" on women's appearances is "a ground of inequity", she remarks that "[i]t's seen as part of women's assets in the public world" (ibid., p. 10). Indeed, on the day of the pageant while the contestants were preparing their hair and makeup, one said, "I hope $\mathrm{x}[\mathrm{sic}]$ wins, [s]he needs the confidence. Maybe then she'll realise she's beautiful" (ibid., p. 8). The contestant appears to imply that success depends on appearance, that a woman should present herself in a particular way in order to gain acceptance from others (employers, for example). The workshops not only enforce feminine stereotypical behaviour and gender roles ("like a lady") but appear to discourage diversity. The workshops therefore suggest that gender fluidity 
such as "unladylike" behaviour and appearance is discouraged, and that failing gender training (as "a lady") means lack of success in later life.

UK feminist writer Natasha Walter maintains that sexism is alive and well today in spite of feminist activism during the last four decades (Cochrane, 2010). Walter's experience as a mother was an influencing factor for the second part of her book Living Dolls: The Return of Sexism (2009), and recalls that when her daughter was born (in 2001) she "was hit by this deluge of pink" whereas when visiting friends' houses boys' bedrooms were "blue and navy, and full of cars and Action Men" (ibid.). She also recalls a parent saying that her son, who wanted to do ballet, "obviously couldn't do it" as "he'd be the only boy in the class" (ibid.). Walter asserts that arguments about "biological programming" of boys and girls have "multiplied in recent years" which imply that boys "natural[ly]" prefer the colour blue, "cars and guns" whereas girls "natural[ly]" like the colour pink, "prams and dolls" (ibid.).

\section{Biological determinism}

From a biological determinist perspective, human behavioural traits such as aggressiveness are based on biological causes (Fausto-Sterling, 1985, pp. 7-8). For example, some claim that men are more "aggressive", "competitive" and "combative" than women because of higher levels of testosterone (ibid., pp. 123-124). Others claim that aggression in children is caused by exposure to higher levels of androgens during prenatal development (ibid., p. 133). Many feminists, however, have historically countered assumptions that sex influences gender, by distinguishing sex as biological features (hormones and external genitalia, for example) and gender as social factors (social role and behavioural traits, for example) (Stanford University, 2011). The key factor for making this distinction was to counter biological determinist perspectives the view that "biology is destiny" (ibid.).

Some theorists such as Anne Fausto-Sterling argue that, instead of "root causes" alone, behaviour arises from "a web of interactions" between an individual's biology and their social environment (Fausto-Sterling, 1985, pp. 7-8). Lowe also argues that biological determinist theories are false in that they pretend that social structures result from the 
innate biology of human beings: that such theories ignore the reality that "social inequality has been constructed along biological lines" (Lowe, 1982, p. 109). She further asserts that the significance of biological determinist theories, which claim differences in behaviour and ability between sexes, arise from these theories' political component (ibid., p. 109). That is, if sex (like class and race) did not have political and economic significance in society, then, Lowe argues, it is possible that people would care little about "biological differences" between members of particular groups (ibid., p. 109). Feminist perspectives on biological determinism are relevant to my analysis of medical rationales for sex assignment of intersex children. This is especially with regard to Money's and Ehrhardt's (1972, pp. 11-12) assertion that genital appearance influences a child's distinct (“dimorphic”) behaviour as male or female. Furthermore, Money argued that genital surgery is not only essential for a child's sense of self as male or female (Harlow, c1977, pp. 25-26) but also their gender role (Money, 1963, p. 56). Money therefore appeared to reinforce a biological determinist claim that girls, based on their genital anatomy, are destined to specific stereotypical roles such as carers of children and homemakers.

\section{"Brain sex"}

Popular, best-selling books such as John Gray's Men are from Mars, Women are from Venus (1992) claim that there are differences in "brain sex": that men and women communicate in different ways and that there are differences in learning between boys and girls (Connell, 2009, p. 50). However Janet Shibley Hyde, a professor of psychology and women's studies, argues for a gender similarities hypothesis which asserts that males and females have similar psychological traits (Hyde, 2005, p. 581). She further argues that "overinflated" claims about gender differences can have negative impacts in areas such as employment (ibid., p. 581). Hyde cites Carol Gilligan's (1982) argument that men and women speak in different "moral voices": that women speak in a "caring" way whereas men speak "in a voice of justice" (ibid., p. 589). She argues that such claims reinforce stereotypes of women and men as "caring and nurturant" and "lacking in nurturance" respectively: that women who "violate" the stereotype of "being nurturant and nice" can be excluded from employment opportunities and receive less than favourable performance appraisals (ibid., p. 590). Another stereotype is that boys 
perform better at mathematics than girls, in which a negative consequence is that girls (even if they achieve good grades) may be "overlooked" by parents and teachers (ibid., p. 590).

Nancy Krieger, a professor of public health and social behaviour, and feminist science academic Elizabeth Fee argue that when sex chromosomes were discovered in 1905 it "reinforced the idea that gender was a fundamental biological trait, and in turn created employment barriers for women to particular occupations (Krieger \& Fee, 1996, p. 20). Lesley Rogers, a professor of neuroscience and animal behaviour, also argues that genes on sex chromosomes (namely X and Y) are "often assumed" to influence "sex differences in thinking and behaviour" (Rogers, 2001, p. 3). A common belief, including amongst scientists, is that a "chain of influence" ("from genes to hormones to brain structure") causes differences in behaviour between men and women, while not considering external influences such as culture (ibid., p. 3). Rogers argues that differences in thinking between men and women may not be because of sex hormones (such as androgens) influencing the brain, but because of differences in upbringing (ibid., p. 82).

\section{Third wave feminism}

Third wave feminism, which developed in the 1990s, is represented by a generation born in the 1960s and 1970s whose political thinking and activism maintains a strong link with second wave feminism that their mothers were influenced by. A difference between second and third wave feminism is that the latter "embraces contradiction and diversity", involves analysis of women's and men's lives and envisages a mode of feminist thought beyond binaries (Genz \& Brabon, 2009, pp. 156-157). Gender and women's studies academics Lesley Heywood and Jennifer Drake define third wave feminism's element of contradiction as oppositions between the second and third waves, and use musician and actor Courtney Love as an example who shows contradictions such as "glamorous and grunge", "girl and boy" and "mothering and selfish" (Heywood \& Drake, 1997, pp. 2-5). Thus Love bridges "postmodern individualism" of the third wave with second wave analyses of "the cult of beauty" and patriarchy (ibid., pp. 2-5). 
Journalist Ana Marie Cox and English major graduates Freya Johnson, Annalee Newitz and Jillian Sandell also bridge second and third wave feminisms via their discussion about being both feminist and male-identified (Cox, Johnson..., \& Sandell, 1997, p. 179). Cox et al. assert that "the relationship between gendered social roles and biological sex is more fluid than we are taught to believe" (Cox et al., 1997, p. 178). Johnson describes that she conveys her feminine attributes from a "campy, gay-boy perspective" instead of a "traditionally feminine one" and that she is "a gay man in drag" whenever she "wear[s] make-up" or "dress[es] up femme" (Johnson; in ibid., pp. 180-181), which Cox describes as a "drag identity" instead of a feminine one (Cox; in ibid., pp. 180-181). Cox herself maintains that her male-identification resulted from her "fail[ure] at being a woman" (ibid., p. 182), and asserts that her "crossing [of] gender boundaries" is proof that "identities are not essentialist" and that gender is inessential which, to her, "is a feminist goal” (ibid., p. 191). Cox's assertion has informed my analysis of medical notions about sex assignment, in which an individual's identity may be irrelevant (hence "inessential") to their sex anatomy.

Third wave feminism is not to be confused with postfeminism, a late 20th century development that has been criticised by some as a "conservative backlash" against second wave feminism (ibid., pp. 1). Heywood and Drake describe postfeminism as "a group of young, conservative feminists" who are critical of second wave feminists (Heywood \& Drake, 1997, p. 1). However, Ann Brooks argues that postfeminism can be regarded as a "theoretical movement" that deconstructs "identity politics", and is consequently "capable of challenging modernist, patriarchal and imperialistic frameworks" (Genz \& Brabon, 2009, p. 27). Thus postmodernism, poststructuralism and postcolonialism can be regarded as "academic" streams of postfeminism respectively (ibid., p. 27). Brooks further asserts that, instead of "depoliticising" feminism, postfeminism is “a political move in feminism's conceptual and theoretical agenda" in which the focus of debate shifts from "equality" to "difference" (ibid., p. 27).

Two such postfeminist strands, feminist poststructuralist theory and postmodern feminist theory, will be discussed in the next two sections. While the latter can be regarded as a polar opposite with second wave feminism, both these theories have provided me with alternative perspectives about diversity and gender fluidity which, I 
suggest, can offer a way out of oppressive gender stereotypes that second wave feminists argued against.

\section{Feminist poststructuralist theory}

Like queer theory, feminist poststructuralist theory aims to "trouble the very categories of male and female", to show the way they are formed and to "question their inevitability" (Davies \& Gannon, 2005, p. 318). Feminist poststructuralist theory also questions the construction of individuals (ibid., p. 318). It analyses how power works "not just to force us into particular ways of being but to make those ways of being desirable" so that individuals adopt them as their own (ibid., p. 318). Feminist poststructuralist research also focuses on "the possibility of moving beyond what is already known and understood" - thus it aims to move beyond the categories of male and female by "multiply[ing] possibilities" (ibid., pp. 319-320). One principle of feminist poststructuralist analysis is not to find out about the "truth" of sex and gender but to "disrupt that which is taken as stable/unquestionable truth" (ibid., pp. 319-320), while another principle is that science is regarded as a set of theories "that produce knowledge in certain ways" instead of a "hallowed discourse that is necessarily better than others" (Haraway, 1991; in ibid., p. 319).

The Intersex Society of North America (ISNA - which closed in March 2008 to become the Accord Alliance $)^{45}$ dispels a myth that they advocate bringing up intersex children in a "third gender" (Intersex Society of North America, 2008). While the ISNA would like society to become less gender-phobic, they do not believe that "dumping intersexed kids into a gender-phobic world with no gender or a 'third gender' is the way to go" (ibid.). The ISNA states that they are trying to create a safe environment for intersex children, and that "we don't think labelling them with a gender category that in essence doesn't exist would help them" (ibid.). These statements by the ISNA appear to imply that people who move beyond the male and female boxes may face serious consequences such as harassment and discrimination.

\footnotetext{
${ }^{45}$ Despite being closed, the ISNA's website (www.isna.org) is still running as an "historical artefact" and provides extensive information. The website of the Accord Alliance is www.accordalliance.org.
} 
Poststructuralist theoretical perspectives of power in societies are relevant to my discussion about New Zealand's small population, in which there appears to be a connection amongst every New Zealander. New Zealand's connectedness, I suggest, therefore contributes to maintaining power structures to silence individuals for the fear of being found out. Judgemental attitudes towards a lesser-known condition, particularly in small town New Zealand, can also wield power to silence and cause individuals to feel isolated. Bronwyn, a mother of two daughters with $\mathrm{CAH}$, talks about the implications of living in a rural New Zealand town in chapter 9. Such attitudes can cause parents to feel reluctant to talk about their children's intersex conditions, and in turn make parents feel isolated, which paediatric endocrinologist Paul Hofman suggests in chapter 9.

\section{Postmodern feminist theory}

Postmodernism can be regarded as a "self-absorbed" theory as it regards a subject as an “autonomous and free agent” (Genz \& Brabon, 2009, pp. 106-107). Postmodernism further argues that subjects, as conceptual forms, are "fluid" instead of "stable" and "constructed" instead of "fixed" (ibid., pp. 106-107). This has caused concern as some maintain that postmodern feminist theory is problematic and incompatible with feminism's strong political involvement (ibid., p. 106), which will be discussed later in this section.

French feminist Monique Wittig argues that "language casts sheaves of reality upon the social body" (Wittig, 1992, pp. 43-44, 78) while Butler, drawing from Wittig's argument, remarks that the question "is it a boy or a girl?" marks the time when a newborn baby becomes "humanised" - thus the "mark of gender" appears that “qualifies” bodies as "human bodies” (Butler, 1990, pp. 141-142). Butler's and Wittig's arguments that "sex" is a linguistic term instead of a biological classification suggests that the term "intersex" may not be a medical term (exclusive to qualified clinicians) to classify a specific intersex condition. Del, a 44-year-old FtM (female-to-male), says:

"I've called myself a gender terrorist, I've called myself intersex by design, an intentional mutation... I call myself a hermaphrodyke sometimes. I've been a lesbian or a dyke; I've been a queer dyke."

(Del; in Hines, 2007, p. 80). 
However, Australian academic Stephen Kerry notes that the intersex movement, as a socio-political community which questions the medical management of intersexuality (Kerry, 2005, pp. 126-127), has raised concern about "intersex" being regarded as a subcategory of "transgender" (ISNA, 2002; in ibid., p. 163). A website asserts that intersexuality is not about biological basis but about how an individual's body has been treated by medical institutions, and notes that transpeople (who may have intersex conditions) voluntarily undergo surgical and hormonal procedures whereas intersex people undergo these procedures without their consent (www.transfeminism.com, 2002; in ibid., p. 164). I therefore appreciate that some people with natural intersex bodies, who have spoken about the trauma of undergoing surgery without their consent (see chapter 7), may, I suggest, take offence to transpeople who claim intersex identity.

Butler comments on the idea that the construction of gender may suggest that "gender meanings" are "inscribed on anatomically differentiated bodies", where bodies are regarded as "passive recipients" of cultural laws (ibid., pp. 11-12). Because of these laws "it seems that gender is determined and fixed as it was under the biology-is-destiny formulation", and thus culture instead of biology becomes destiny (ibid., pp. 11-12). Butler's arguments about "gender meanings" and cultural laws have informed my analyses of sex assignment recommended by clinicians - for instance, female assignment based on physical traits such as ovaries. This theoretical perspective has informed my thinking that sex assignment is based on societal expectations (hence culture) about "normal" anatomy. Like Butler, in Lesbians Talk Transgender (1996) Zachary I Nataf distinguishes gender and sex as "cultural rather than natural” in which, for example, an individual's sex is assigned by a doctor's glance at birth which then forms an opinion of "gender status" (Nataf, 1996, p. 17). Nataf remarks that "[g]ender identity is the subjective sense of being a gender, the sense of who I am” (ibid., p. 18). He thus argues that if bodies and identities are separate entities, then in reality an individual's sense of "belonging to a category" can be different to the one attributed by someone else (ibid., p. 18). Nataf's argument about bodies and identities being separate entities has influenced my argument that anatomy does not influence an individual's gender identity, no matter how many medical procedures occur, which is highlighted by Briffa's account in the next chapter. 
Essentialism, from feminist perspectives, is the view that "there are properties essential to women, in that any woman must necessarily have those properties to be a woman at all" (Stone, 2007, pp. 18-19). Pre-second wave views of women were usually traditional and essentialist, and assumed that all women are classified as women by biological features such as uteruses or breasts (ibid., pp. 18-19). Second wave feminists then highlighted the sex/gender distinction by arguing that biological sex is different from gender, in that while being "female" may require particular anatomical characteristics, being a "woman" identifies with the "feminine gender" - for example, social traits and roles (ibid., pp. 18-19). Alison Stone argues that essentialism "is simply false as a description of social reality" and that its falseness is what makes it "politically oppressive" (ibid., pp. 18-19). It could be argued that medical texts convey essentialist views that some female-assigned children should have vaginas surgically constructed in order to become "normal" women. This further relates to the Human Rights Commission's Intersex Inquiry, in which one submitter asserted that her gender identity was female (HRC, 2007, p. 81). Stone's perspective has therefore informed my argument that a woman's body - no matter how ambiguous - is inessential to her gender identity.

In Gender Trouble's (1999 edition) preface, Butler recalls that in 1989 she sought to counter views of a "pervasive heterosexual assumption in feminist literary theory" that "restricted the meaning of gender to received notions of masculinity and femininity", and questions the "fear" of dismantling the gender binary code:

Is the breakdown of gender binaries, for instance, so monstrous, so frightening, that it must be held to be definitionally impossible and heuristically precluded from any effort to think gender?

(Butler, 1999, pp. vii-viii).

Whelehan remarks that in a postmodern utopia the male/female gender binary code may cease to exist, but argues that politically feminists have a strong case to retain the male/female binary in their analysis of power structures (Whelehan, 1995, p. 199) as: “Utopias are the 'no-places' of a future where society has transformed into something other than our present realities" (ibid., p. 214). While Butler's arguments have influenced my argument that the male/female binary code can be oppressive, particularly with regard to medical rationale for sex assignment, I am nevertheless acutely aware of 
Whelehan's argument about retaining the male/female binary in analysing injustices between male and female categories. An example is Warne's comment that "boys do not" usually require genital surgery (Warne, 1980). Thus, while I argue for gender diversity, Whelehan's argument is nevertheless important to examine a stark difference between female-assigned and male-assigned children.

Linda Nicholson similarly argues that postmodernism has been "blind and insensitive to questions of gender" in its supposed political analysis, and that "if seriously adopted by feminists" would make feminist politics appear impossible (Nicholson, 1990, pp. 75-76; in Whelehan, 1995, p. 202). Whelehan also argues that postmodernism's proposal to dismantle gender binaries takes away the chance for feminist academics "to analyse the impact of their own female identity" in a social setting (ibid., p. 202). Sheila Jeffries raises a sobering testament against postmodern feminist theory by arguing that, in a scenario of a woman experiencing domestic violence by her male partner, "is this because she has adopted the female gender in her appearance?" (Jeffries, 1994, p. 100; in ibid., pp. 206-207). Jeffries remarks that a postmodern solution may be that the woman adopts a stereotypical masculine appearance and "strut about in a work shirt or leather chaps" (ibid., p. 207). Thus postmodernism, she argues, makes women's oppression become invisible when gender is regarded "as an idea, or a form of appearance" (ibid., p. 207).

Again, while I support gender diversity, these arguments and concerns by Nicholson, Whelehan and Jeffries to retain the male/female binary have informed my analysis of differences in medical management between male- and female-assigned children, such as essentialist views by clinicians that women with androgen insensitivity syndrome "must" have their testes removed - because society's culture (Millett, 1971, p. 31) forbids this. Feminist arguments to retain the binary has also influenced my analysis of sex assignment with regard to recommendations about "rearing as male" or "rearing as female". This is highlighted by Money's argument that gender stereotypes are essential for humanity's survival (Money \& Tucker, 1975, pp. 38-39), which resonates with feminist arguments about oppressive stereotypes - for example, "the cult of the 1950s housewife", that pioneering feminist Friedan argued against (Hoby, 2010; Fox, 2006). Sheila Jeffries' and Linda Nicholson's arguments about postmodernism “threatening" 
female identity changed my thinking about gender fluidity - as if female gender identity is "bad" and the cause of one's oppression.

But while Jeffries' argument about discrimination against female appearances influenced my thinking about the notion of "female rearing", Butler's argument about "gender meanings" and cultural laws (Butler, 1990, pp. 11-12) were still relevant in my analysis of discrimination. I illustrate this with regard to a scenario of a "delicate"looking six-year-old girl who loves wearing pink, frilly dresses, and who is discouraged by her parents from playing football or wanting to be an engineer when she grows up. In this scenario I argue that the girl experienced discrimination not only because her interest and ambition go against Money's recommendation of female stereotypes supposed dislike of "dirty[ness]" (Money, 1975, p. 68) and interest in housework (ibid., p. 69) - but because of the cultural laws and gender meanings inscribed on the girl's appearance.

\section{Queer theory}

While some feminist critics argue that queer theory focuses more on gender than political theories, others note queer theory's political objectives about difference and visibility of non-heterosexual communities which evolved from the Gay Liberation Movement - notably the Stonewall Riots in New York in 1969 (Genz \& Brabon, 2009, p. 124). Queer theory challenges a two-sex, two-gender and one sexuality system which places people into categories and divides them into being labelled "normal" or "deviant" (Filax et al., 2005, pp. 81-82). Nataf argues that medicine reinforces "the dimorphic view of the human sexes (only two distinct forms)": that "you can only have one sex, which is assigned to you by medical professionals, and that your gender identity and role should correspond exactly and unproblematically to this 'fact' of sex" (Nataf, 1996, p. 18). Richard Ekins, from the University of Ulster at Coleraine (UK), similarly argues that medical institutions appear to counter gender politics by reinforcing "a rigidly perceived binary gender divide" in which transpeople were expected to undergo gender reassignment surgery, "pass" as men or women and "live heteronormative lives" (Ekins, 2005, p. 308; in Factor \& Rothblum, 2008, p. 242). In distinguishing sex and gender, Nataf also states that "[ $\mathrm{t}]$ ransgender says sex and gender ambiguity exists, that all 
identity is not coherent, that gender identity does not necessarily correspond to the genitals you have" (Nataf, 1996, p. 18).

Queer theory also challenges traditional notions of sexuality - in particular, compulsory heterosexuality. Cheryl Chase remarks how according to doctors "male genitals are for active penetration and pleasure while female genitals are for passive penetration and reproduction: men have sex; women have babies" (Chase, 1998, p. 210). She also argues that the terms "homosexual", "lesbian" and "intersex" were invented by medicine to classify "disapproved sexualities" as diseases (ibid., p. 212). Consequently, she states, "I must proudly assert my identity and insist that the medical construction of intersexuality as disease is oppression, not science" (ibid., p. 212). Chase's queer theoretical argument has informed my analysis of assumptions about heterosexuality, with regard to "normalising" surgery to enable "comfortable" sexual intercourse as a heterosexual. Her argument about "active" and "passive penetration" has further informed my thinking about the sexual double-standard, akin to Ehrenreich and English's argument about female sexuality: the societal expectation that women were not supposed to enjoy sex (Ehrenreich \& English, 1978, p. 47) - she would otherwise risk "getting a reputation" (Matthews, 1984, p. 122) - and that "real women" supposedly want to have children, or she is "selfish" (Shanner, 2009, p. 407).

\section{Conclusions}

Greer's comment about feminine sex stereotypes, that "[n]o musculature must distort the smoothness of the lines of her body" (Greer, 1970, p. 69), resonates with some intersex people's experiences (in the next chapter) about being forced to take female hormones (Bragge, 2005) because of their assignment as female. Greer's comment also reflects another observation about differences between male- and female-assigned children: female-assigned children are administered oestrogen to make their bodies appear more feminine - hence align with this sex stereotype of not being muscular (Viloria, 2011). However, Greer's essentialist views towards AIS women, whom she dismisses as "damaged males" (Greer, 1999, p. 70) because of their XY karyotype, reflect Stone's argument that essentialism is "politically oppressive" against some women (Stone, 2007, pp. 18-19). Greer's views about AIS women in The Whole 
Woman (1999) also appear to refute her views about female stereotypes in her earlier book The Female Eunuch (1970), when she asserts that she "refuse[s] to be a female impersonator" and that she is "a woman, not a castrate" (Greer, 1970, p. 70).

A feminist poststructuralist principle of "moving beyond what is already known and understood" (Davies \& Gannon, 2005, pp. 319-320) is highlighted by Cox et al.'s assertion that the relationship between gender and anatomical sex is more fluid than society assumes (Cox et al., 1997, p. 178). This account appears to not only disrupt the assumption that gender is only male or female, but echoes Whelehan's remark about a postmodern utopia (Whelehan, 1995, p. 199) - in this case a place where ambiguous bodies are accepted and supported. In this utopian scenario this acceptance becomes all the more possible when intersex activists (in the next chapter) aim to increase the visibility of intersex communities by becoming public about their intersex states, as well as educating the public that having an intersexed body is not necessarily a bad thing (Viloria, 2011). From a feminist poststructuralist perspective (Davies \& Gannon, 2005, p. 318) it is societal power structures - characterised by fear and prejudice towards indifference - which ensure that particular communities remain hidden and that, in relation to Whelehan's comment, such utopias remain "no-places" (Whelehan, 1995, p. 214).

Third wave feminism has a lot to offer to not only debates about the clinical management of intersexuality, but support and empowerment to people with intersex conditions. While second wave feminist activism has focused on women's experiences as women, third wave feminism is more inclusive in that it embraces diversity (men's experiences, for example) and thinking beyond binary categories. This is with regard to Chase's concern (in chapter 2) that some feminists do not consider intersex people as they are not "normatively women" (Chase, 1998, p. 208; in Kitzinger, 1999, p. 498). Cox et al. offer a more inclusive perspective in their assertions that individuals can be both male-identified and feminist (Cox et al., 1997, p. 179), and that fluidity occurs between gender and "biological sex" (ibid., p. 178). Thus third wave feminism can enable second wave feminism and postfeminist strands, such as postmodernism and queer theory, to become compatible with each other in analysing the clinical management of intersexuality. This can be achieved by examining differences (and 
Theorising "boy or girl" binary classifications, intersexuality and medical practice in New Zealand

inequalities) between male and female sex classifications, and at the same time injustices towards individuals whose sexual anatomy and genders do not meet typical male or female norms. 


\section{Chapter 7:}

\section{People's first hand experiences - what's already out there?}

This chapter outlines a selection of what has already been published about people with variations of sexual anatomy, and their experiences with medical institutions. I will discuss gender stereotypes with regard to people's childhood recollections of their upbringings, in accordance with their assignment as female as opposed to male. I will also outline people's understandings about "normalising" procedures with regard to societal fears and prejudices towards sexual ambiguity.

Two issues emerge from people's experiences: trauma and silence. With the issue of trauma, a common childhood experience amongst people was of regular genital examinations and being used for medical teaching purposes, which resulted in feelings of shame, dehumanisation and what some regarded as "freakishness". With the issue of silence, a common experience during childhood was that intersexuality was something never to tell anyone about and, years later, finding out the truth about their hospital visits.

\section{Experiences in New Zealand}

New Zealand's first qualitative research of intersex people's experiences was undertaken by registered nurse Drew MacKenzie as part of her Masters in Nursing (ITANZ, 2011). Another qualitative study in New Zealand was undertaken by neonatal nurse specialist Leigh McCarthy (see chapter 12). MacKenzie's findings, outlined in a Journal of Clinical Nursing article co-written with fellow registered nurses Annette Huntington and Jean A Gilmour, focus on three intersex people's experiences in New Zealand. MacKenzie et al. note three themes from the interview transcripts: "managing silence, coping with difference and development of acceptance" (MacKenzie.

Huntington, \& Gilmour, 2009, pp. 1777-1778). 
In MacKenzie et al.'s first theme of "managing silence” (MacKenzie et al., 2009, p. 1778), participant Jordan ${ }^{46}$ recalls how at home he was "never allowed to venture further than the sound" of his mother's voice as if he had "done something really bad" (Jordon; in ibid., p. 1778). When Douglas asked her mother about her birth "she started screaming and crying and ran out of the room" and "we never talked about it again, ever" (Douglas; in ibid., p. 1778). The authors' second theme of "coping with difference" drew from each participant's view of their gender during childhood (ibid., p. 1778). Douglas recalls her parents" expectations of "feminine behaviour" when her mother "tried to push me into girl things" and that she even received formal lessons on flower-arranging: "In the end Mum gave up, but it clearly distressed her" (Douglas; in ibid., p. 1778). Experiences of school also featured discussions on this theme (ibid., p. 1779). Kate recalls that her concern "with the absence of breasts" influenced her to keep her physical variation "really secret" from her peers, in that teasing for having a "flat chest" increased Kate's concern about "what would it be like if they knew about the rest of me" (Kate; in ibid., p. 1779).

However, once the participants had broken their silence about their intersexuality, the authors" third theme of "development of acceptance" emerged when they received support from friends and family members (ibid., p. 1779). Douglas recalls that the first time she met other intersex people was "just amazing, mind blowing" (Douglas; in ibid., p. 1779). When Jordan heard Douglas talk about intersex issues on a radio programme, he remarks that "it was a great weight lifted off my shoulders" and that her "braveness" on talking publicly had given him "freedom" (Jordan; in ibid., p. 1780). All three participants did not wish for surgery despite the challenge of "being different" (ibid., p. 1780). Douglas remarks that it "take[s] away our own unique eroticism" (Douglas; in ibid., p. 1780) while Kate, who never underwent surgery during childhood, advises that "unless there is an absolute need for it, keep the scalpels away" (Kate; in ibid., p. 1780).

The three participants' comments about accepting their physical variances, particularly when they received support from others, contrasts with Low et al.'s claim (in chapter 2) that society is not yet ready to accept people "who [do] not neatly fall into the 'male' or

\footnotetext{
${ }^{46}$ Pseudonyms were used for all three participants to ensure confidentiality (MacKenzie et al., 2009, p. 1777).
} 
'female' category" (Low et al., 2003, p. 406). While some sectors of society may regard intersexuality as an "abnormality" and associate it with "freakishness", others who were supportive towards Douglas, Kate and Jordan suggest that parts of society are more accepting of people with intersex conditions. Jordan's experience of silence and feeling that he had "done something really bad" suggests a society that considers sexual ambiguity to be "bad". However, Jordan's mother may have been trying to protect him from teasing, thus it is the fear of teasing and rejection that silences people - as Kate experienced because of her "flat chest".

In the television documentary Mani's Story (2002), about New Zealand intersex activist Mani Mitchell (born Bruce in 1953), narrator Jim Mora says that "just before his first birthday medical experts in Auckland took another look at baby Bruce" - Mitchell then tells how they performed a laparotomy (Keir, 2002). The documentary contains an excerpt from the short film Hermaphrodites Speak! (Intersex Society of North America, 1996) in which Mitchell remarks:

\footnotetext{
My sex was identified, as with many hermaphrodites... [pulling down trousers and lifting up top, and showing a vertical abdominal scar] that was the test to see which gender I was going to be assigned, and because males can't have uteruses my sex assignment was changed to female.
}

(Mitchell; in Intersex Society of North America, 1996).

The documentary then shows Mitchell in Kirikau, a small rural town near Taumarunui where she grew up, describing how soon after her laparotomy a "community meeting" occurred at the local school hall in order to "deal with this really difficult situation":

\footnotetext{
What was decided was that they [the local community] would pretend that I'd always been a girl, and... not talk to Mum and Dad about what had happened. So you have this crazy situation where Mum and Dad knew, everyone in the valley knew, but no one was talking about it. And that was the situation, they all knew and I didn't know.
}

(Mitchell; in Keir, 2002).

Again the issue of silence emerges from the community meeting, which echoes societal attitudes that a physical state of both male and femaleness is "shameful" and "taboo". As information resources (such as McCarthy's pamphlet discussed in chapter 12) and support groups would have been non-existent during this time, this suggests that the community felt that the only way to deal with a "taboo" situation was to keep quiet. Mitchell's situation is akin to the case of David Reimer (who like Mitchell was initially 
named Bruce) in which Money advised Reimer's parents to keep quiet about the circumcision accident and pretend that Brenda (as David was then) had always been a girl. In Mitchell's case, Mora tells how "baby Bruce became baby Margaret” and consequently "gone were the blue boys' clothes, replaced by pink frilly dresses". Later, when she was eight years old Mitchell went to Auckland - "Suddenly she was in hospital, no one said why", and she was used as a "teaching opportunity" for medical students (Keir, 2002):

In an earlier current affairs segment "A Sexual Dilemma" by 20/20 reporter Karen Pickersgill, Mitchell recalls:

I was taken into a teaching theatre, unsedated... lying in this teaching theatre on a table, surrounded by young doctors. And so I'm a child trying to work out what's going on, what's going to happen, absolutely terrified.

(Mitchell; in Pickersgill, 1997).

Surgeons performed a "feminising genitoplasty" (Keir, 2002) which involved the removal of a phallic-like structure from her genitalia and the creation of a neovagina (Pickersgill, 1997). Mitchell gives her thoughts on her experiences of hospitals:

\begin{abstract}
[presenting at intersex conference in the USA] Medical people find us fascinating, like so fascinating we become hospital freak show tours. [at her home in New Zealand] There's enormous sadness, pain, grief around what was taken from me, to make other people feel comfortable. That was done with absolutely the best intentions... and I have now - didn't used to, but certainly now no negative feelings to those people because it was all done thinking that that was the best thing to do.
\end{abstract}

(Mitchell; in Keir, 2002).

As a young adult training to be a teacher Mitchell recalls asking her mother about her birth. Her mother became very upset as she remembered the nurse "blurting out" at Mitchell's birth, "Oh my God, it's a hermaphrodite" (Keir, 2002). Silence on Mitchell's intersex state occurred when she and her mother never talked about the matter again (ibid.). But shortly after her mother died Mitchell, then aged in her early 30s, finally found out the truth from an old Plunket book her mother had left her (Pickersgill, 1997). The documentary shows the book being opened to reveal "Margaret Ruth" handwritten on a piece of sellotape inserted beside "Name of Child" (Keir, 2002). The sellotape is then removed to reveal a handwritten "Bruce Mitchell", then on a page headed "Nurse's Comments and Advice:-" is a handwritten "nice wee lad" (ibid.). At about 1989, when 
she was working in civil defence, Mitchell began to embrace her intersex self and changed her name from Margaret to Mani - an Indian Sanskrit name meaning "both male and female" (Pickersgill, 1997; Keir, 2002). She also stopped cutting her facial hair: "Everything else about my different body has been literally cut off, so it was an act of both reclaiming my difference and a celebration at the same time" (Mitchell; in Keir, 2002).

While some people such as Mitchell assert their intersex identity, an Inquiry launched in 2006 by the New Zealand Human Rights Commission noted that intersex people held wide-ranging views about gender identity and sex anatomy (HRC, 2007, p. 3). It was noted that while some intersex people stated gender identities that were neither male nor female and others identified as transgender, particularly if they were undergoing surgery or hormone administration to reverse previous procedures (ibid., pp. 80-81), other people's identities were firmly male or female:

\begin{abstract}
My gender identity is unequivocally female... While it seems to fascinate some nonintersex folk that there could be a state of engenderment outside a male-female binary, I find that labelling to be demeaning when applied to me. Although some intersex people might want to avoid rigid gender labelling, I would not like to see a situation where a history of intersexuality was always equated with gender fluidity: I am hurt when my gender is not affirmed in the same way as the general population.
\end{abstract}

(Woman born with an intersex condition; in HRC, 2007, p. 81).

The woman's assertion about her female gender identity echoes essentialist feminist arguments on what constitutes a "proper" female. Like AIS women (Morland, 2006, p. 328; in Dreger \& Herndon, 2009, p. 215), I believe that she would take issue with Greer's (1999) argument that individuals should not call themselves women unless they have an XX karyotype, uterus and ovaries.

\title{
Experiences in other countries
}

In 1994 Sarah Graham, then aged 25, was finally able to put a name to her condition androgen insensitivity syndrome (AIS) (Graham, 2006). Graham describes the "complete shock" of finding out that, when she had surgery as an eight-year-old, it was not her ovaries that were removed but her testes (ibid.). A gynaecologist had lied to her parents: that if Graham's ovaries were not removed before puberty she would develop terminal cancer (ibid.). Graham describes how her journey started in 1977 when she 
was referred to "a world eminent gynaecologist" after experiencing abdominal pain and undergoing tests (ibid.). She was then examined by the gynaecologist and "what seemed like an army of medical students", who announced in front of everyone that Graham was a "very special little girl" (ibid.). The issue of silence emerges in that it was a clinician who kept silent about Graham's testes by lying to her parents.

In Canada Morgan Holmes describes other intersex people "feeling deeply ashamed and abused" from being treated like research objects by clinicians because of their “interesting” bodies (Holmes, 2002, p. 169). Kiira Triea, born during the mid-1960s, recalls feeling like a "lab rat" during examinations by John Money and other clinicians at Johns Hopkins Hospital: of being "[t]ested, photographed, tested again, photographed some more", and that this very "treatment" prevented any feelings of " "normal' happiness" (Triea, 1997; in ibid., p. 169). Diane Anger, born in 1964, recalls "the many horrible, tense visits" to specialist clinicians "to have my genitals gawked, fondled and stared at by hordes of what I perceived to be nasty, despicable men" which resulted in her "questioning my own existence as a person, male or female" (Anger, 1997; in ibid., pp. 169-170). Thea Hillman, an advocate for patient-centred care of individuals with intersex conditions and who has $\mathrm{CAH}$ herself, similarly recalls that from the age of four her genitals were regularly examined by male doctors every few months (Hillman; in SFHRC, 2004). From these examinations Hillman recalls that feelings of "difference" and "what was wrong with me" were in relation to her "sex" and "privates", and remarks how she had "excellent support from my parents - my mother especially, and a caring doctor" (ibid.). However, she comments that these examinations left her with the "emotional scars of a sexual abuse survivor" and that she wishes she had been told that it was "OK to be different sexually", as this would "have saved me a lot of soulsearching, alienation and grief" (ibid.).

Graham remembers that as an eight-year-old in hospital she was "the only child alone on the ward" and that she "tried to run away, but was caught and held down by the nurses" (Graham, 2006). "I soon realised that I had no human rights and this was confirmed when, the night before my op, I was given an enema in front of my mother" (ibid.). Later, Graham continued to see "different gynaecologists twice a year for check-ups" all of whom withheld the truth from her (ibid.). When Graham was 17 she fell in love 
with a woman and recalls how coming out as a lesbian was a "very happy experience" (ibid.). Then while studying at university in London she became involved in gay rights activism, which caused her to think strongly about sexuality and gender, and was soon describing herself as "queer" instead of "lesbian" as the term rejected "heterosoc[iety]'s rules" (ibid.). Graham remarks that she is "the living embodiment of an apparent contradiction" as her body appears "outwardly female" but that she has a male chromosome type (XY) - hence an "XY woman (both female and male)", and that:

We are a largely invisible oppressed minority, and the fear, fascination and loathing our bodies provoke in modern Western culture has held the power to shame and silence me for years.

(Graham, 2006).

Holmes comments that she was born with "a clitoris large enough that it threatened the possibility of growing into a certifiable phallus (if not exactly a penis)", and that surgery resulted in "stolen physical potential, emotional harm, and the loss of years within a potentially legitimate identity/community of queer and intersex culture" (Holmes, 1998, p. 221). Despite "having [her] body altered against [her] will" (ibid., p. 224) when she was aged seven (ibid., p. 222), she firmly asserts her intersex identity to challenge “normalising" procedures:

My point here is that although I find myself in a committed relationship with a man, and
have produced a child in that relationship, I am not just another happy het[erosexual]. ... I
should have been left alone to mature in a body that quite feasibly could have penetrated
another with its phalloclit[oris]. I should have been allowed to grow up to blur the physical
markers of sexuality, but I wasn't given that freedom. So I want to take it back by force. I
do so by insisting that people think about my marriage as that between a man and an
intersexual.

(Holmes, 1998, p. 225).

Holmes' argument raises a question on whether clinical procedures are biased towards heterosexuality - that some clinicians assume that all female-assigned children will want to have heterosexual relationships when they get older. This reflects Adrienne Rich's argument about compulsory heterosexuality - that lesbian existence has either been ignored or regarded as "deviant” (Rich, 1981, p. 4). With regard to Holmes' comment about not being "another happy het" (Holmes, 1998, p. 225), one can imagine a scenario of a newborn baby with $\mathrm{CAH}$ in which clinical tests reveal a uterus, ovaries and an XX chromosome type. The later adult may not want a vagina for heterosexual 
intercourse and may not want to menstruate or become pregnant, and may be perfectly happy about having an enlarged clitoris for penetration during intercourse.

Sal, born during the 1980s, describes the trauma of having sexual sensation taken from her as a result of her clitoris being amputated when she was three months old. She does not accept the rationale that it was "oversized" as she feels "completely and totally female" and asserts that " $\mathrm{t}] \mathrm{h}$ here was no medical problem with my clitoris, no disease, just an offence to somebody else" (Sal; in Harper, 2007, p. 100). With regard to parents' fears of children experiencing bullying, Sal firmly states that her sexual sensation should not have been removed just because she may have been bullied or "embarrassed her parents", and that schools should adopt an anti-bullying stance and teach children about differences (ibid., p. 100). She also questions "appropriate gender assignment" as she is unable to experience the "joy of sexual sensation" when she states: "what is the point of being one sex or the other anyway?" (ibid., p. 100). Sal's last statement questions Yee et al.'s remark (in chapter 2) about ambiguous genitalia presenting a challenge to clinicians for establishing a "rational sex assignment" (Yee et al., 2003, p. 406). Sal's comment that her genitalia were "an offence to somebody else" suggests that some clinicians focus on social concerns with no regard to loss of physical sensation, which resembles Money and Ehrhardt's argument for genital surgeries as, they assert, people are "gossipy” about another person's intersex condition (Money \& Ehrhardt, 1972, p. 152).

Cheryl Chase also had her clitoris removed when she was 18 months old. She describes the "emotional numbness" of seeing her medical records for the first time when she was 21 , to find out the truth about her clitoris' removal:

"Diagnosis: true hermaphrodite. Operation: clitorectomy." The hospital record showed Charlie admitted... His typewritten name had been crudely crossed out and "Cheryl" scribbled over it.

(Chase, 1998, p. 205).

Chase then recalls the shock of being labelled a "hermaphrodite" by clinicians when she identified as a lesbian woman, and that this very word was "horribly wounding" (ibid., pp. 205-206). Then 11 years later she suddenly experienced "extreme emotional turmoil and suicidal despair", but regards this time as her "coming out as a political intersexual" 
(ibid., pp. 205-206). Chase then discusses how her childhood was "a lie" as after her surgery her parents disposed of "every scrap of evidence that Charlie had ever existed", including photographs and birthday cards (ibid., pp. 205-206). Chase also remembers her parents telling her about her operation when she was 10, that when she was a baby she was "sick", that her clitoris was "too big" and that she "had to go into the hospital" to have it removed (ibid., pp. 205-206). Chase's parents then reassured her, "Now everything is fine. But don't ever tell this to anyone else" (ibid., p. 211). Chase later angrily counters the issue of silence:

For whose benefit does this mechanism of medical erasure and social silencing operate? Certainly, it does not benefit intersexed children. I have been brutally mutilated, left to wonder and to search for the truth in utter silence and isolation.

(Chase, 1998, p. 212).

In contrast to others, Hida Viloria outlines her experiences of growing up in an intersex body without medical intervention. Viloria, born in 1968 in New York City, attributes this to her father, a clinician, who knew that she was healthy and that, as a clinician, "he couldn't be pressured into medically unnecessary surgeries as parents often are" (ibid.). At school Viloria was popular amongst her peers and achieved academic and sporting success (ibid.). She remarks that she was "relieved" that her breasts did not develop as much as her friends' breasts did "because I liked my fit, slender body, that was easy to run and jump with" (ibid.). She also recalls seeing another girl's genitals for the first time, in a swimming pool changing room at the age of 11, and thinking "she's missing something” (ibid.). The girl's “missing” (ibid.) aspect was likely an enlarged clitoris. Like Viloria's childhood recollection, one can imagine a scenario of a changing room situation where some intersex children, who did not undergo surgery, could nevertheless consider their genitals to be normal.

With regard to her lesser-developed breasts, Viloria recalls that soon after she started her periods her father told her she would need to take pills "to help me grow", but that her mother argued with and convinced her father that their daughter "didn't need them" (ibid.). She later found out these pills contained oestrogen to promote breast development and comments on a typical occurrence when intersex children reach puberty: girls are administered oestrogen to develop " feminine' bodies" whereas boys are administered testosterone to develop “"masculine” ones” (ibid.). Viloria also 
comments on intersex individuals born with small penises and undescended testes, subsequently removed because of their "female" assignment, who were "left with huge breasts" as a result of oestrogen administration - despite "[feeling] like boys all their lives" (ibid.). Differences in hormone administration - oestrogen for girls and testosterone for boys - highlight stereotypically gendered bodies. The practice of administering female-assigned children oestrogen, because of their female designation, also suggests it is related to societal fears about masculine (butch) women - the stereotype that women are not supposed to be strong and muscular.

Viloria states that the reason for publishing her experiences is to make people aware that growing up with a variation of sexual anatomy "is not necessarily a negative experience, any more than growing up typically male or female" (ibid.). While "openly sharing this very private information" was difficult, she remarks that it would be wrong not to in the hope that "normalising" procedures may be reconsidered (ibid.). Viloria also rebuts concerns about children being teased in changing room situations: "Unlike other physical differences people are born with, private parts are just that: private" (ibid.). This relates to another aspect in that if parents consider "there is something wrong" with their child then the child will believe this too (ibid.). Probably the most significant issue about "normalising" procedures is that they will not alter an individual's gender identity and sexual orientation: "Even with tons of [o] estrogen pumped through their bodies since infancy, people who were originally intersex boys most often grew up to still feel like boys" (ibid.). Likewise Viloria comments that clitoral reduction procedures do not cause women to become "more feminine" and heterosexual but reduces or eliminates sexual function (ibid.). Such procedures have in fact caused many women to avoid relationships with men "who they believe will be unsatisfied with their substandard sexual abilities", and instead seek relationships with women "because they are less afraid of being judged by other women" (ibid.).

With regard to Ransley's assertion that not undertaking medical procedures is "walking away from the issue" (Harper, 2007, pp. 32-33), Viloria asserts that children's happiness is the key issue as variations of sexual anatomy "are just that: private" (Viloria, 2011). Other intersex people have spoken publicly about wishing that clinicians had done exactly that - nothing. Thus procedures to make them "look more normal", together 
with repeated examinations, were in fact the cause of intersex people's emotional harm - which in my view make childhood teasing appear trivial in comparison.

On 27 May 2004 the San Francisco Human Rights Commission held a televised public hearing at San Francisco City Hall, to investigate medical procedures being performed on children born with variations of sexual anatomy. Those who gave oral testimonies included intersex people such as Eli seMbessikwini, from Australia, who describes how she was "lied to" by her parents and clinicians for 30 years (seMbessikwini; in SFHRC, 2004). At less than a year old seMbessikwini underwent clitoral reduction surgery, and again when she was 10: "The most sensitive parts of my body connected to pleasure, sex and relationships cut with a knife and sutured before I was old enough to discover them for myself" (ibid.). She states that she was born with testes in "a body that looked like a baby girl's" and an XY karytope, and that she "would have gradually virilised to look like a man after puberty" (ibid.). SeMbessikwini also comments that, when clinicians removed her testes when she was 10, "they took away my chance of ever fathering [sic] a child, something that I want very much" (ibid.).

SeMbessikwini is "not obsessively upset about [her] gender identity, but body dysphoria" (ibid.). She remarks how she is "seething" that her "perfectly healthy body was so invasively and irreversibly operated on", as well as receiving hormone administration, tests and examinations (ibid.). SeMbessikwini says she doesn't know how to cope with being "castrated and sterilised for no good reason... all perfectly legal and at the hands of the experts' standard practice", and asserts, "I want my own natural body back" (ibid.). SeMbessikwini also describes how clinicians removed her trust: "In my bad moments I feel like a living experiment" (ibid.). Significantly, she says, "The truth is I was never sick, there was absolutely nothing wrong with me" (ibid.).

SeMbessikwini's comments about her birth anatomy indicate that, like Graham (2006), she has androgen insensitivity syndrome (AIS).

\section{The right to choose one's gender}

When Tony Briffa was born in 1970, in the Melbourne suburb of Altona, clinicians were unable to "confidently announce" whether his parents had a son or a daughter - unlike 
his older twin sister who was immediately announced as a girl (Bragge, 2005). While Briffa's sex chromosome type was found to be XY (male), clinicians advised his parents that he "would be better off" assigned female and to be "unambiguously" brought up as one: "That meant a pink room, lots of dolls for Christmas and birthdays, frilly dresses and my ears pierced when I was two" (Briffa; in ibid.). Like many individuals with AIS, clinicians falsely told his parents that his "gonads" (clinicians did not reveal they were testes) were cancerous (ibid.). They were subsequently removed and any further masculinisation ceased (ibid.). As Maltese immigrants who understood little English, Briffa's parents did not question clinicians and accepted their recommendations for surgical and hormonal procedures (ibid.). The regular examinations that Briffa experienced at Royal Children's Hospital during childhood and adolescence caused him to "feel like a sideshow freak", which he describes as "a form of child abuse" though "unintentional", and left him with physical and emotional scars (ibid.).

Despite his female upbringing, and oestrogen administration which began at the age of 11, Briffa was a tomboy who preferred fighting with other boys instead of "stereotypical girlish" activities (ibid.). When he was 12 and older he "repeatedly" told clinicians that he was "a boy" and did not want to develop breasts (ibid.). Clinicians told Briffa that his body would "reject" testosterone administration, but in 1999 he discovered that this was a lie (ibid.). Clinicians also incorrectly told Briffa that he had the complete form of AIS instead of the correct diagnosis of partial AIS (ibid.). Briffa is understandably angry at clinicians for not telling him the truth - PAIS left alone would have provided some masculinisation - and asserts that clinicians should have let him choose his preferred male phenotype instead of "having synthetic femaleness forced upon him" (ibid.). After trying to "fit in" as a female, in 2000 at the age of 30, Briffa decided to live as he had "always felt - as a male" (ibid.).

Clinicians' advice to Briffa's parents, that he would be "better off" assigned and brought up as female, resembles Money's experiment with the Reimer twins and argument "that boys and girls are made, not born" (Colapinto, 2000, p. 69). Briffa's luridly stereotypical female upbringing - that he would have hated considering his tomboyish preferences - also questions Warne's (1997, p. 7) advice on making a decision to bring up a PAIS child as male or female. Indeed, his assertion that clinicians should have let 
him choose his own body also resonates with Viloria's assertion that no amount of oestrogen administration will cause someone to identify as female. I would argue that giving a child particular toys, clothes and a particular coloured room, based on societal expectations of femininity, is not only unnecessary as the child may dislike these but sexist as, I further argue, masculine behaviour is not influenced by biological factors but societal expectations (the notion "boys will be boys", for example). My argument not only applies to children with intersex conditions but all children, as plenty of girls born with typical female sexual characteristics and chromosome types $(46, \mathrm{XX})$ enjoy activities such as playing rugby and riding BMX bikes, and want to be engineers or Air Force pilots when they grow up. Briffa's experiences further challenge Ransley's advice about preventing testosterone from "affecting" the brain of female-assigned children (Harper, 2007, pp. 32-33). Briffa clearly wanted to be a boy as he told clinicians which counters Warne's (1997, p. 17) advice about early removal of testes from PAIS children being brought up as female. If clinicians had "done nothing" Briffa, as he had always wanted, would have gained a more masculine body naturally.

Briffa, who is secretary of the AIS Support Group, is a devoted foster parent to two teenagers who have no problem in regarding Briffa as both a "foster mother and foster father" - to his foster children "he is simply Tony" (ibid.). Briffa's role as a foster parent and seMbessikwini's desire to "father a child", which could have been possible via spermatozoa from her testes - had they remained intact, reinforces clinician Quigley's (2009) advice to parents about telling intersex children that "not everyone has children the 'ordinary' way". Briffa's foster parent role as and seMbessikwini's paternal desire further break down "archetypal male and female roles" (Firestone, 1971, p. 15) within a traditional model of, as Firestone asserts, a "biological family" (ibid., pp. 1011). Briffa's foster children regard him in both mother and father roles - not one or the other according to traditional family modes, and while known by the feminine title "Ms" and pronoun "she" (de María Arana, 2005, p. 34) seMbessikwini wants to become a father instead of a mother. 


\section{The desire for intersex embodiment}

A discussion thread from the Bodies Like Ours ${ }^{47}$ website further questions medicine's rationale for "normalising" procedures, when someone asks about procedures with the goal of achieving an intersex anatomy. Ruun asks on behalf of a friend, "who's felt out of place with her body since she was quite young", about the possibility of becoming "surgically intersexed" (Ruun, 2011). In his reply Peter comments about "transmen who are also intersex" and that he has "heard of a person being 'intersex by design"" 48 Peter, who underwent "normalising" genital surgery without his consent, remarks that "[p]eople are generally much happier about surgery... when they are actively involved in making decisions" and advises that "it is important to find a really good doctor who really cares about their patients" (Peter, 2011). In a subsequent reply Peggy comments that the term "intersex" usually refers to an individual with a physical variation "from birth", not as a result of medical procedures (Peggy, 2011). Like Peter, Peggy advises Ruun's friend to investigate procedures that transmen (female-to-males) undergo (ibid.). She also remarks that Ruun's friend could select which procedures she wished to undergo or not, and that "[m]any people with gender identity issues do just that" (ibid.).

This discussion resonates with Nataf's argument on the societal assumption that only clinicians can attribute sex classifications to individuals at birth (Nataf, 1996, p. 17). Ruun's friend's desire for an intersex body also resonates with Nataf's transgender perspective (in relation to queer theory) that physical and gender ambiguity exists (ibid., p. 18). However, as discussed in chapter 6 , intersex activists raise concern about intersex being associated with transgender identity (ISNA, 2002; in Kerry, 2005, p. 163) in terms of human rights issues - namely the right to consent to medical procedures. Emi Koyama asserts that non-intersex people should not combine "intersex experiences with lesbian, gay, bisexual or trans (LGBT) experiences" (Koyama, 2002; in ibid., p. 165). Koyama also states that while non-intersex people may empathise with feelings of growing up "different" they do not fully understand "what it means to grow up

\footnotetext{
${ }^{47}$ Bodies Like Ours is a support community that aims "to end the shame and secrecy" and create acceptance of being born with variations of sexual anatomy (source: Bodies Like Ours website, www.bodieslikeours.org).

${ }^{48}$ The case of Del, a female-to-male (FtM) who describes himself as "intersex by design" (Hines, 2007, p. $80)$, is outlined in chapter 6 .
} 
intersexed" (Koyama, 2002; in ibid., p. 165). The ISNA also cautions LGBT organisations in adding an "I" (for intersex) unless they are committed to undertaking advocacy for intersex people, and that the "I" in LGBTI "should not be just a fashion statement" (ISNA, 2002; in ibid., p. 165). As I discussed in chapter 6, some people born with intersex bodies, who have actively campaigned for patient-centred rights (Hillman; in SFHRC, 2004), may, I suggest, feel that it is inappropriate for Ruun's friend to use the term "surgically intersexed" (Ruun, 2011). With regard to the ISNA's caution, I can appreciate that some intersex activists may perceive a non-intersex person's desire to claim the term "intersex" as trying to be "fashionably trendy" (Du Plessis, 2004, p. 111).

\section{Conclusions}

I argue that informed consent for medical teaching purposes is not just a feminist issue but a human rights issue that concerns everyone, particularly those with less common variations of anatomy that may attract "voyeuristic"-type attention. As Mitchell remarks, medicine's "fascination" for "unusual" anatomies has meant that intersex people in hospitals have been more susceptible than others to being used for teaching purposes (Mitchell; in Keir, 2002), and as a consequence many intersex people had traumatic experiences in hospitals. Some clinicians" "fascination" with "unusual[ness]" also meant that they failed to acknowledge that these "interesting cases" were human beings with feelings, who felt violated and dehumanised by invasive examinations - at times with little or no explanation by clinicians.

I also argue that silence, like trauma, is just as harmful. As Graham recalled the "shock" of finding out the truth about her surgery 17 years later "nearly killed [her]" and caused "an emotional meltdown" (Graham, 2006). Likewise, when Chase viewed her medical records for the first time, finding out that her childhood was "a lie" caused her to feel suicidal (Chase, 1998, pp. 205-206). I would say that erasure of Chase's birth identity as a boy, when her parents disposed of every aspect of Charlie's life (ibid., pp. 205-206), would have been harmful too in the sense that Chase was denied the right to know about her early childhood. This also occurred in New Zealand when Mitchell had her birth identity withheld from her, when her community decided it would "be best" to keep 
quiet about her early life as Bruce (Mitchell; in Keir, 2002). Societal attitudes towards subjects regarded as taboo, I would argue, also instigate silence. As Mitchell recalled, the subject of intersexuality (via the word "hermaphrodite") caused her mother to become upset and "never [talk] about [it] again" (Mitchell; in ibid.). I suggest that this is because, for some, hermaphroditism (as intersexuality was formerly known as) carries connotations of "freakishness" (Quigley, 2009) because of societal discomfort towards a mixture of male and female characteristics.

Like Viloria, I argue that silence and societal fears about intersexuality can be overcome by publicity and education, particularly as intersexuality "is not necessarily a negative experience” (Viloria, 2011). Jordan's experience (in MacKenzie et al., 2009, p. 1780) also shows that publicity about lesser-known conditions can not only provide visibility but empowerment to individuals with such conditions. Indeed, hearing a fellow intersex person's voice on a radio programme caused Jordan to feel that pressure - no doubt from silence and secrecy - had been alleviated, and in turn he felt free. 


\section{Chapter 8: \\ Methodologies and methods}

Initially I had hoped to interview many people with intersex conditions in New Zealand, in order to get a broad range of perspectives, but only five people agreed to participate. With regard to my first research question, I originally intended to examine intersexuality from medical perspectives alone. However, with regard to traditional assumptions about gender and sexuality, my view changed after reading feminist theories and intersex people's accounts which influenced my thinking that the latter's voices should take priority. My views about gender also evolved from my background reading and conversations with some community/support organisation representatives. In particular, Nicholson's (1990, pp. 75-76; in Whelehan, 1995, p. 202) and Jeffries' (1994, p. 100; in ibid., p. 207) concerns about postmodern feminist theory influenced my thinking that the male/female binary code is necessary in order to analyse differences between male and female categories, such as differences in surgical procedures between male- and femaleassigned children. My second research question relates to the small number of intersex New Zealanders who agreed to be interviewed. Consequently, in order to get a broader perspective of intersexuality in New Zealand, I then sought the perspectives of community/support organisations, registered nurses and parents of children with intersex conditions.

I will first discuss theories about oral history: in particular, the view that we can only accept what narrators say as the truth, as their accounts may be impossible to verify (Portelli, 1991, p. 51). This is because some narrators may hide aspects of what truthfully happened (ibid., pp. 52-53), particularly if these aspects are personal and private, for example. This is in relation to the next section about undertaking research on what can be regarded as a sensitive topic, especially with regard to obtaining ethical approval. With regard to my third research question, I will then discuss how undertaking research on a sensitive topic becomes more difficult in New Zealand with its small population, which especially creates difficulties in maintaining confidentiality.

Later, I will discuss my research methods and the reasons for using these, and discuss how building a relationship and trust with one support organisation - not achieved in a 
short time - enabled me to find intersex participants. I will then reflect on the difficulties I experienced in trying to find intersex participants, compared to others such as clinicians and community/support organisation representatives. I will discuss these difficulties from methodological perspectives about research on sensitive topics.

\section{Theorising oral history}

Oral history can offer a fairer viewpoint of historical events by including the voices of less-powerful people (Thompson, 1988, p. 28). For example, when studying poverty social historians can shift their interview focus from government officials and politicians to poor people themselves in order to find out about their conditions, survival strategies and so on (ibid., p. 28). Thus oral history can not only enable a shift in research focus from the powerful to the less powerful, but open "important new areas of inquiry" and give "recognition to substantial groups of people who [have] been ignored" (ibid., p. 29).

Alessandro Portelli comments that, as "narrative sources" (Portelli, 1991, p. 48), oral historical sources from "non-hegemonic classes are linked to the tradition of the folk narrative" (ibid., p. 49). This marks a distinction between narrative sources and traditionally written sources from "the educated classes" (ibid., p. 49). Portelli further comments on a distinction between "factual" ("events") and "artistic" ("feeling or imagination") narratives (ibid., p. 49). A “boundary” between what actually occurs "outside the narrator and what happens inside", and between what involves an individual person and a wider group of people, will result in "more elusive" sources compared to "established written" sources - thus "personal 'truth' may coincide with shared 'imagination"” (ibid., p. 49). Portelli remarks that oral history sources are unique in that they not so much inform about actual events but their meaning, in that interviews "often reveal unknown events or unknown aspects of known events" as well as showing new perspectives towards "unexplored areas of the daily life of the non-hegemonic classes" (ibid., p. 50). This then raises a question about "verification" of oral history sources in that they are "credible but with a different credibility" (ibid., p. 51). Portelli's comment about the distinction between written and narrative sources echoes Patricia Maguire's perspective about knowledge being a form of power (Maguire, 2008, pp. 420- 
421 ), in that the voices of "ordinary people" are not regarded as legitimate as medical publications, for example. This perspective by Portelli has influenced my argument that the voices of intersex people are just as important as clinicians' recommendations in medical publications.

Oral and written historical sources have not existed separately as narrators read books and newspapers, listen to radio and television programmes, and keep diaries, newspaper clippings and letters - thus "modern orality itself is saturated with writing" (Portelli, 1991, p. 52). Portelli also comments that the most valuable information is that which a narrator hides instead of what is actually told, which causes "colouring" of a story (ibid., pp. 52-53). This is not because a narrator is unable to remember particular events but because of changes that occurred in the narrator's life, such as changes in their personal circumstances or political opinions, for example (ibid., pp 52-53). Also, actions considered "normal" or "legitimate" during a past time period may now be regarded as "unacceptable" and hence "cast out" of what a narrator plans to tell a researcher (ibid., p. 53).

Portelli's (1991, p. 53) perspective suggests that people with intersex conditions, whom I interviewed, may have withheld pieces of information from me. While I may have regarded those hidden pieces as "valuable" to my research, they may have regarded this hidden information as personal and private that should not be released, as Portelli would say, outside their "boundary" (ibid., p. 49). His comment that oral and written sources coexist are reflected by intersex people's accounts in the previous chapter: when Jordan heard Mani Mitchell talk on a radio programme, and intersex people's voices appearing as words via online discussion forums. From Portelli's perspective this raises a question as to whether the narratives of people, such as Ruun's account of a friend (Ruun, 2011), can ever be verified. But as Portelli remarks, the significance of narrative sources is not so much about the telling of actual events but their meaning (Portelli, 1991, p. 50).

Thus while Ruun's statement, that a friend has "felt out of place with her body since she was quite young” (Ruun, 2011), may be impossible to verify, Ruun's narrative gives a meaning about gender. Ruun's narrative further gives a meaning about an aspect or "unexplored area" of gender - that is, gender fluidity and identity beyond male/female binary classifications. 


\section{Research on sensitive topics}

Raymond Lee defines sensitive research as "research which potentially poses a substantial threat to those who are or have been involved in it", and that it is threatening in three ways:

- Intrusive threat, when research deals with subject matter that is "private" or "stressful" - for example, sexual practices;

- Threat of sanction, when subject matter can be considered "deviant" in that information collected may stigmatise or incriminate participants; and

- Political threat, when research involves the "powerful in society" in which researchers may be entering prohibited areas "that involve some sort of social conflict" (Lee, 1993, p. 4; in Dickson-Swift, James \& Liamputtong, 2008, p. 2).

Lee and Claire Renzetti comment that research may also be considered threatening when it "intrudes into the private sphere or delves into some deeply personal experience", is interested in "deviance or social control" or if it "impinges on the vested interests of powerful persons" (Lee \& Renzetti, 1993, p. 6; in ibid., p. 3). Virginia Dickson-Swift, Erica Lyn James and Pranee Liamputtong comment that research may also be considered sensitive when its subject matter may not just be private to some people but emotional as well, in that participating in research may be an emotionally-draining and stressful experience (ibid., p. 3). However, despite Claire Draucker's concerns about subject matter "unleashing painful emotions and memories in participants" (Draucker, 1999, p. 162; in ibid., p. 5), Dickson-Swift et al. later remark that research on sensitive topics needs to be undertaken, in that deliberately avoiding such subject matter may be regarded by some researchers as an "evasion of responsibility" (ibid., p. 6). As Joan Sieber and Liz Stanley argue: "Although ignoring the ethical issues in sensitive research is not a responsible approach to science, shying away from controversial topics, simply because they are controversial, is also an avoidance of responsibility" (Sieber \& Stanley, 1988, p. 55; in ibid., p. 6).

When considering Lee's (1993, p. 4; in ibid., p. 2) comment, some intersex people whom I encountered at meetings may have considered my research an "intrusive threat" 
to a very private and personal part of their lives that they did not wish to disclose. Though I was acutely aware of issues of trauma experienced by many intersex people I was also aware that gender and the clinical management of intersexuality is an underresearched topic in New Zealand. My interest in undertaking this research was made stronger by my contact with community/support organisations, some of whom invited me to talk about my research at meetings and conferences - from which I received positive feedback.

Obtaining ethical approval to undertake data collection brought home that research on my chosen topic could be regarded as sensitive. I first submitted an ethics application to Victoria University's Human Ethics Committee which then advised me to submit an application to the Health and Disabilities Ethics Committees (part of New Zealand's Ministry of Health). Accordingly, I submitted an application to the Multi-region Ethics Committee as I intended to interview participants from throughout New Zealand. In May 2009 I attended a meeting with members of the committee who raised concerns about me interviewing participants on what could be regarded as a sensitive topic, particularly with regard to ensuring confidentiality. A few committee members expressed concern about participants possibly becoming upset during interviews. With regard to arguments by Dickson-Swift et al. (2008, p. 6) and Sieber and Stanley (1988, p. 55), I informed committee members of the importance of my chosen topic as little research had been undertaken in New Zealand. I asserted that it was important to record the voices of intersex people in order to help others in the future, as well as assisting clinicians to provide optimal health services for intersex people and their families. I also informed committee members that, should participants become upset during interviews, counselling and support services would be available to them (see Appendix II).

Using Raymond Lee's (1993, p. 4; in Dickson-Swift et al., 2008, p. 2) perspective, intersexuality can be considered a sensitive research topic as some intersex people may have regarded my research as an intrusive threat, as it deals with subject matter that to them may be very private - thus some people may have been reluctant to talk to me about it. This in turn may have influenced intersex people to regard my research as a threat of sanction, as they may consider that disclosing private information about 
themselves may stigmatise them. With regard to Lee's comment about subject matter being "stressful", reading people's accounts made me acutely aware of the trauma that some people had experienced, particularly from childhood experiences of hospitals such as being "shown" to groups of medical students as if they were research objects, and being denied full and truthful explanations of why they were in hospital.

Some publications and support organisation representatives also informed me about the importance of appropriate language when undertaking research on a sensitive topic. Like one submitter to the Inquiry, who asserts that her "gender identity is unequivocally female" (HRC, 2007, p. 81), some intersex people may have also been reluctant to participate as they may have felt that my research associated intersexuality with gender fluidity - that I was biased towards gender fluidity. Consequently, when I gave presentations about my research at conferences and meetings, I stated that, as well as undertaking recorded interviews, support organisations had been advising me about undertaking research appropriately - particularly on appropriate language. In presentations I stated that, while I had met some people who identify as intersex or queer, I was aware that others find the term "intersex" offensive. I also stated that, while I support gender diversity and fluidity, I equally support male and female gender identity irrespective of anatomy.

Even without a face-to-face interview, for some completing a written questionnaire anonymously may still be emotionally-draining and stressful (ibid., p. 3). And from Claire Draucker's (p. 162; in ibid., p. 5) perspective, even writing about subject matter anonymously may run the risk of "unleashing painful emotions and memories in participants" about past traumatic experiences. In order for people to talk to me about this sensitive and personal topic, building trust with a contact person of a support organisation was essential. When Sarah from one support organisation attended a presentation I gave at a conference, not only may she have been interested in my research, she may have been "auditioning" me to determine whether I was genuine about my research - and to determine if participants would feel comfortable talking to me. Thus this audition for Sarah was the test - and I passed. Proof of this was an email from Sarah to members of her support organisation (which she forwarded to me separately). Sarah's e-mail not only invited members to participate in interviews but 
included statements such as "Geraldine is very committed to her research (this on top of a full-time job)" and "this [confidentiality] is $110 \%$ guaranteed". Sarah may have also considered that, despite my research topic being considered sensitive, my research would be helpful to her support organisation's members and their families.

From his interviews with Holocaust survivors, Mark Klempner notes that "traumatic memory" can distort narratives in terms of "block[ing] out" parts of a full story (Klempner, 2000, p. 201). One narrator talked about having "holes in her memory", not that she had forgotten about her experiences but that she had "blocked [them] out because they were very painful" (Martine N; in ibid., p. 201). This theme was suggested by Lisa's and Jacqui's experiences of surgery during childhood (see chapter 11) in terms of "block[ing] it out" (Jacqui, 2010, interview). Despite possible gaps in data collection, I was sensitive to Lisa's and Jacqui's discomfort during our interviews. I therefore refrained from probing further on what may have been painful or even embarrassing experiences. As Klempner advises, a participant's “emotional, mental, and spiritual well being" must take priority - thus researchers should never "push for material" that may cause distress (Klempner, 2000, p. 208).

\section{Maintaining confidentiality in New Zealand}

Feminist oral historian Lesley Hall suggests that maintaining confidentiality can be difficult in countries such as New Zealand with small populations (Hall, 2004, p. 152), where "everyone seems to know everyone else" (ibid., p. 159). When Hall worked as a rape/sexual abuse telephone counsellor she sometimes recognised callers' voices and, as a university lecturer, has assessed oral history assignments in which she sometimes recognised narrators' voices - despite a pseudonym being used (ibid., p. 159). Indeed, the implication of living in a lesser-populated country such as New Zealand may, I suggest, have made some intersex people reluctant to participate in interviews for the fear of being found out by others. Consequently, when participants completed the Consent Form (see Appendix V) I respected some of their wishes to remain completely anonymous, while others were happy to use a pseudonym. However, even pseudonyms could be problematic. Jacqui was originally referred to by a different pseudonym until her younger sister Lisa requested that I change it, as she felt it was too similar to one of 
her true given names. Consequently, I respected Lisa's wish and referred to her older sister as Jacqui.

Because New Zealand's small population has implications on maintaining confidentiality, I respected participants' wishes that information about them would be modified or even fully disguised. I always e-mailed participants the full transcripts of recorded interviews, so that they could thoroughly read transcripts and confirm (via email reply) that they were comfortable with the information. This was particularly as some participants requested that information be modified further, as some felt that there were "too many details" that could identify them - particularly in New Zealand. Consequently, in chapters 9 to 12 I have withheld details such as names of cities, specialist clinicians and hospitals that some participants commented on. Because of the connectedness amongst New Zealanders (as discussed in chapter 1), I have even withheld details of regions where some participants lived - particularly as some lived in rural or provincial areas. I have also withheld the names of parents' children by using, for example, "my child" or "my daughter" instead.

Participants also have the option (as per Parts B and C of the Consent Form) to have their recorded interviews archived at the Alexander Turnbull Library, part of the National Library of New Zealand. Archiving oral histories has a significant importance in preserving the voices of the less powerful (see Thompson, 1988, p. 28), so that they may be heard by future generations. Some participants were very keen for their interviews to be archived, particularly to help others such as parents or to educate future health professionals in New Zealand. Other participants firmly requested that their recorded interviews be deleted, despite my comments that their interviews could help others and that they could choose restricted access (to registered nurses only, for example) to their recordings. One participant stated that she did not want her details "getting in the system", which suggests that she may want to "block out" (erase memories of) embarrassing or painful experiences (Klempner, 2000, p. 201). With regard to Klempner's advice about respecting a participant's emotional well-being (ibid., p. 208), I therefore respected some participants' wishes about deleting their recordings. 


\section{Feminist research methodology - ethics, dilemmas and principles}

A defining principle of feminist research is that research on women should benefit women (Kirsch, 1999, p. 1). Ann Oakley's research on pregnant working-class women was a pioneering model of feminist research methodology, in which she developed a sense of "moral obligation" to help the women (ibid., p. 2). Instead of following traditional research procedures such as "maintain[ing] distance”, Oakley’s approach towards participants therefore became "more interactive, collaborative, and less hierarchical" in that she discussed medical concerns with participants and helped them to access prenatal care (ibid., p. 2). Feminist researchers have argued that scientific and sociological research has often "misrepresented", "belittled" or "ignored" women's experiences (ibid., p. 8). A gross case of misrepresentation is highlighted from Phyllis Chesler's research (Women and Madness) on the history of electric shock treatment (ibid., p. 8). A finding was that psychiatrists and clinicians during the 1950 s often prescribed shock treatment for women because of their unhappiness in accepting "domestic obligations" - made greater by "a desire" to follow "artistic or career aspirations" (ibid., pp. 8-9). Feminist research methodology was relevant to my research questions in relation to social justice issues and gender disparities, as highlighted by intersex people's experiences.

Feminist research aims to "establish interactive and non-hierarchical relations amongst researchers and participants" via "open-ended interviews", in order to easily establish rapport and allow close bonds to form between "women interviewing other women" for example, sharing experiences of motherhood (Kirsch, 1999, pp. 25-26). A rapport was established during my interview with Jacqui when we shared a short-lived childhood experience with Brownies because of less-adventurous activities such as "knit[ting] things" (Jacqui, 2010, interview). We both agreed that if Cub and Scout groups then accepted girls we would have probably both joined, as these groups offered more adventurous activities such as "building tents and crossing streams" (ibid.). Indeed, we both agreed that it is wonderful that girls in Cub and Scout groups today "get to go out doing boys' stuff' (ibid.) which was denied from our childhoods. While I did not share Jacqui's physical condition of $\mathrm{CAH}$, from a feminist research perspective we 
nevertheless shared a gender disparity during our childhoods based on our classifications as female.

Thus dismantling hierarchal and power relations between researchers and participants can sometimes lead to friendships which can continue long after completion of research projects (Kirsch, 1999, p. 26). However, Sondra Hale and Daphne Patai raise important ethical issues and possible dangers of undertaking recorded interviews. Hale describes how her fieldwork of Sudanese women involved "intense friendship interactions" which made her feel like an "insider" and that she "led a charmed life in still-colonial Khartoum, embraced so completely by a women's community and given special treatment" (Hale, 1991, p. 122). But after her third and fourth trips to Sudan, and being influenced by the student and civil rights movements of the 1970s, she questioned her right to undertake fieldwork in Sudan: "to objectify people through the interview method for my own career ends" (ibid., pp. 121-122). Patai describes how exploitation becomes more possible "when the researcher is interviewing 'down', that is, among groups less powerful (economically, politically, socially) than the researcher herself" (Patai, 1991, p. 137). She later raises a significant question: "How is the research returned?" (ibid., p. 147).

Patai's question, I suggest, relates to a probable reason on why some intersex people may have been reluctant to participate in recorded interviews. Some intersex people may have thought there was little or no point in participating in my research as, to them, it may simply sit on a university library shelf "doing nothing” (Patai, 1991, p. 141), while in relation to "objectify[ing] people" (Hale, 1991, pp. 121-122) some may have thought "it's only going to benefit Geraldine's $\mathrm{PhD}$ " or “it's only going to benefit Victoria University". I was after all not a registered nurse undertaking research for a hospital endocrinology department, for example, nor was I an intersex person representing a GLBTIQ-type support organisation.

I did, however, endeavour to empower participants by telling them that, as it was their interview, they could have support people with them during the interview and did not have to answer questions. Thus I endeavoured to make participants feel that they (not I) had complete control over their interviews. I would also e-mail them their interview 
transcripts for their comment and amendment as they felt fit, particularly as some participants requested that their interview be modified or fully disguised in order to ensure confidentiality. I also gave presentations at conferences and meetings so that possible participants would see that I was genuine and, like Sarah, test me by having the opportunity to approach me and ask me questions. This method enabled a shift in power relations between the researcher and (potentially) researched, as potential participants took on the role of "interviewer" at conferences and meetings - some of whom later participated in recorded interviews.

\section{Queer methodology}

With regard to queer theory's challenge of a two-sex, two-gender and one sexuality system, an understanding of the idea and processes of "normalisation" is very important in queer theoretical research (Filax et al., 2005, pp. 81-82). Similarly to feminist methodology, queer methodology offers a form of "critical scholarship" that examines "unequal and unjust social relations" based on gender, sexuality and sex classifications. It also maintains a "political commitment to promote radical social and political change that undermines oppression and marginalisation" (Nash, 2010, p. 131). However, some scholars argue that while queer methodology is "interesting theoretically" with regard to fluidity and "playful[ness]" it remains mostly detached from the concrete realities of “everyday life” (Browne \& Nash, 2010, p. 6).

Indeed, while some intersex people I interviewed firmly identify as female, a counsellor stated that, in real-life situations, ambiguous physical appearance can affect an individual socially in terms of mental health issues such as depression (Natalie, 2011, interview). "Social groupings", she said, tend to accept others according to male or female norms and exclude those who do not (ibid.). Also, while some such as Holmes assert their intersex identity in association with "queer culture" (Holmes, 1998, p. 221), a support organisation representative I interviewed notes that some women in her group find the term "intersex" offensive (Sarah, 2010, interview). New Zealand feminist academic Rosemary Du Plessis also questions if there is a danger of heterosexual feminists using queer theory to "jump on an intellectual bandwagon", as it is a very appealing (if not "fashionably trendy") theoretical perspective (Du Plessis, 2004, p. 
111). She comments on the sense of being an "outsider" and the "rights to claim association" (ibid., p. 111). This is illustrated by Wei Leng Kwok's reflection as a heterosexual feminist experiencing "heterosexual (guilt)", when she was challenged at a seminar about her use of queer theory (ibid., p. 111). While I have always found queer theory very appealing, particularly as a "rebellion" (ibid., p. 103) against gender and sex stereotypes, an incident during my fieldwork caused me to question my use of this theoretical perspective. When I attended a GLBTIQ-type conference to give a presentation about my research (which contained queer theoretical references), during an informal group discussion someone assumed that I was a dyke. When I replied that I was straight, another person challenged my attendance at the conference which, like Kwok, caused me to feel guilty - and even ask myself if I was coming across as pretentious ("trendy"). Later in this chapter I discuss the implications of being an outsider when trying to find willing intersex narrators.

\section{Lectures and tutorials at tertiary institutes}

I wanted to sit in on lectures to find out what medical schools and midwifery programmes in New Zealand teach about intersexuality and compare any differences in course content, particularly with regard to gender and sexuality matters. After e-mail conversations with relevant medical school departments and subsequent referrals to specialist heads of departments, I managed to attend two "Reproduction and Endocrinology” (MBChB303) lectures at Auckland Medical School's Grafton campus, and two paediatric surgery seminars (conducted like tutorials) for fifth year medical students at Christchurch School of Medicine (part of Otago University). Following contact with a nursing school at another tertiary institute ${ }^{49}$ I also managed to attend and contribute to a midwifery lecture (see chapter 12). As reading course outlines and medical journals and textbooks only provided a limited insight on what students are taught, I wanted to attend lectures and tutorials in person to gain a better understanding of the type of teaching that medical and midwifery students receive. As well as the rationale for particular procedures, I was also interested in finding out the extent to which gender and sexuality issues are included in medical and midwifery programmes.

\footnotetext{
${ }^{49}$ As the Midwifery Programme Director requested that information be modified I have withheld details of this tertiary institute in New Zealand.
} 
For example, I wanted to find out if the teaching covers diverse aspects of gender fa'afafine, for example) and perspectives that sex anatomy may not correspond with gender identity (Nataf, 1996, p. 18).

\section{Specialist clinicians and registered nurses}

From February 2008 to May 2010 I contacted various specialist clinicians throughout New Zealand via e-mail. At first my research approach was of an "exploratory" nature as I was interested in finding out whether variations of sexual anatomy are commonly encountered by clinicians in New Zealand. So at this stage my aim was to obtain quantitative, statistical information about specific intersex conditions and procedures undertaken in New Zealand. I did not select clinicians randomly. I first checked their “online registrations" on the Medical Council of New Zealand's website (www.mcnz.org.nz), and then determined if a clinician's work and specialty would be relevant to my research by obtaining further information from internet searches (for example, online medical journal articles). In total I e-mailed 16 endocrinologists, 31 paediatricians, 17 obstetricians and/or gynaecologists, and 24 urologists. Chris McEwan, a plastic surgeon, was contacted and subsequently interviewed after I attended his presentation at a conference which included aspects about gender.

I have not provided statistical information in this thesis as the majority of clinicians either did not reply to my e-mail or provided "nil" replies with statements such as "I don't see any intersex patients". Some also suggested I contact others such as Paul Hofman whom I subsequently met. I also approached other clinicians, whose e-mail replies contained interesting comments, about participating in an interview in order to obtain more detailed information. As a consequence my research approach changed from quantitative to qualitative, as I was interested in finding out more about medical training, particularly if it included gender issues such as "appropriate gender assignment" and even gender diversity. I also wanted to find out clinicians' rationale for performing or recommending particular procedures - for example, concerns about children experiencing teasing. Most importantly, I wanted to find out about the type of support clinicians offered to intersex people and their families. 
I also approached registered nurses who deal with intersex children and their families, whom I learnt about from community/support organisation newsletter articles and contact people. Like clinicians, I wanted to find out about the type of support and advice nurses offer to parents of intersex children, and whether support and advice from nurses differed from clinicians.

\section{Community/support organisations}

I knew no other openly intersex people in New Zealand apart from Mani Mitchell. I approached various community/support organisations throughout New Zealand who forwarded my e-mail and information sheet to their e-mail distribution groups. Larger organisations published a short article about my research in their newsletters which reached to a wide range of people.

Contact people from many GLBTIQ-type organisations advised that they did not know of any members either with intersex conditions or who identified as intersex, but that they would distribute my information to their members (see Appendix III) - I received no response to this. Later, when I found out from a newspaper article that one regional GLBTIQ-type organisation had intersex members, I telephoned the contact person whom I had met before at conferences. The contact person advised that intersex members would not want to be interviewed, so I suggested that they could complete a written questionnaire and post it to me anonymously via a stamped addressed return envelope. The contact person agreed with this method and I e-mailed her a written questionnaire to be distributed to intersex members - she also offered to supply stamped return envelopes to members. However, despite this anonymous data-gathering method I did not receive any completed written questionnaires. This lack of response was probably because, I suggest, not only is intersexuality such a sensitive and personal topic but for some recollections may be too painful to even write about - as highlighted by intersex people's experiences.

I suggest that another probable reason why I did not find a greater number of intersex participants was that I was a complete outsider. As previously stated I do not have an intersex condition nor was I, for example, a registered nurse who regularly encountered intersex babies and their families. I was also not a parent of a child with an intersex 
condition - nor do I have any children - and, as far as I know, no one in my wider family has an intersex condition. Indeed, lesbian academic and oral historian Alison J Laurie comments that Elizabeth Labovsky Kennedy and Madeline D Davis interviewed 45 lesbians in Buffalo, New York, as they were "trusted insiders" (Laurie, 2004, p. 61). But in New Zealand little information has been gathered about lesbians in New Zealand as they "led secret lives of concealment in order to protect themselves and their relationships (ibid., p. 61). The fact that I was not an insider, I suggest, is a possible reason why some intersex people were reluctant to participate in my research, as they may have felt that I did not have similar experiences as them.

Despite my outsider status I contacted two intersex people, whom I had met before a few times at conferences and meetings, about participating in interviews which did not eventuate. When I telephoned one person it was clear from our conversation that she did not wish to be interviewed. From reading about intersex people's experiences I fully appreciated and respected the person's wishes - which had made me hesitant and nervous about contacting her in the first place. The second person I contacted was via Mani Mitchell, who forwarded my e-mail (see Appendix III) and information sheet (see Appendix II) to him. I also visited the region he lived in a few times as I was undertaking other research activities, and I e-mailed him about my visits a week beforehand. In his early e-mail replies the second person appeared willing to be interviewed - at one time apologising for a delayed reply, but later he stopped replying to my e-mails. Apart from an e-mail address I had no other contact details for the second person, so an interview never eventuated.

It is also possible that my research, with its strong focus on medical management, may have caused some intersex people to feel reluctant about participating. This is because it may have brought back painful memories of negative hospital experiences which they did not want to recall.

Despite my lack of success in finding intersex people who were willing to be participants, I approached representatives from community/support organisations (none of whom, apart from Mani Mitchell, were intersex people) who were willing to be interviewed. Again I was interested in finding out about what support they offered to 
intersex people and their families. Also, as community/support organisations play an education role I wanted to find out their recommendations for the medical training curriculum in New Zealand, for students or junior doctors encountering intersex and gender issues. Priscilla Penniket was one such person who provided particularly interesting perspectives on societal attitudes towards gender and intersexuality, from her role as Education Co-ordinator for Rainbow Youth (see chapter 12).

I eventually succeeded in finding other intersex participants when I approached Sarah, a director of a support organisation for parents of intersex children. ${ }^{50}$ I was interested in interviewing parents as they would have first hand experience of a key issue in my research - recommended sex assignment by clinicians. I was also interested in parents' viewpoints in comparison to clinicians' advice I had read about in medical texts, such as birth announcements and what to tell friends and family.

As I only interviewed five people with intersex conditions in New Zealand, I visited community/support organisation websites, such as Bodies Like Ours, in order to view the narratives of intersex people via online discussion forums. From my internet searches I also obtained intersex people's stories posted on community/support organisation websites, as well as from news websites such as the Melbourne Age (as with Tony Briffa's account). However, echoing Portelli's (1991, p. 51) argument, from my internet search results it was impossible to determine which websites and online discussion forums were legitimate. While I used extensive word searches on the Google search engine, with words such as "intersex", "gender", "surgery” and "discussion”, many search results appeared fetish-like, voyeuristic and pretentious. However, my internet search results also contained legitimate news websites such as the Independent (UK) which brought up Graham's (2006) article and Briffa's account (Bragge, 2005), who told their stories in the Independent and Melbourne Age respectively. My searches also contained support community websites such as Bodies Like Ours which contained Viloria's (2011) views about surgery. Indeed, she stated that she wanted to publish her experiences so as to make others aware about intersex issues in the hope that “normalising” procedures may be reconsidered (Viloria, 2011).

\footnotetext{
${ }^{50}$ As requested by Sarah, the name of this organisation has been withheld.
} 


\section{Methods}

One of the reasons why I undertook recorded interviews ${ }^{51}$ with participants is that, even during a single session, a participant can provide an extensive amount of information. During interviews participants also often made interesting comments, which then provoked me to ask further questions beyond those outlined in the sample interview questionnaire I e-mailed participants beforehand. Thus, by raising further questions to a participant's comments, a recorded interviewing method enabled me to expand on information already being provided during an interview. Another reason was to enable access to other participants via a word-of-mouth ("snowballing") method: if a participant felt that their interview was a worthwhile and positive experience, they could then tell other participants (akin to providing a verbal reference about me). This occurred during my first interview with Lisa, a woman with $\mathrm{CAH}$, when she commented that her older sister Jacqui has CAH too. I later asked Lisa if I could contact Jacqui about participating in an interview. Lisa agreed and gave me her sister's contact details and - following an initial e-mail and telephone conversation with Jacqui - I obtained another participant. A similar snowballing effect also occurred when some participants suggested I contact other people who were, for example, involved in community/support-type work relevant to my research.

As stated previously I offered participants the option of answering questions in writing, as completing written questionnaires anonymously is a method that would ensure complete confidentiality with regard to Lee's (1993, p. 4; in Dickson-Swift et al., 2008, p. 2) argument about research on a sensitive topic being an "intrusive threat". Partly as a result of unsuccessfully accessing intersex members of the regional GLBTIQ-type organisation I contacted, I decided that giving presentations about my research at meetings and conferences organised by community/support- and GLBTIQ-type support organisations could be an effective method to recruit possible participants - who would see me in person and judge me accordingly. Thus I believed that presenting at conferences and meetings would enable trust-building to occur from participants. Those seeing me speak at a conference may become interested in participating themselves -

\footnotetext{
${ }^{51}$ The recording equipment I used was a Fostex FR 2LE digital recorder with AKG C417PP clip-on microphones.
} 
particularly as they could approach me and ask me questions during the break periods, or "provide a reference" for me by telling others. As a result, presenting at conferences and meetings provided an effective "networking" method with representatives from other community/support- and GLBTIQ-type organisations. I also created and printed a supply of business cards and information sheets, which consequently became exchanged with representatives. A "snowballing" method occurred when some representatives invited me to give further presentations at other meetings and conferences. A goal achieved from this method was that I obtained further participants who were willing to undertake recorded interviews.

This method's success was probably because of a complete shift in power relations between the researcher (myself) and potential participants. I thought back to when I telephoned an intersex person who obviously did not want to be interviewed and, with regard to Lee's (1993, p. 4; in ibid., p. 2) perspective, may have felt very nervous and threatened when I "cold-called" her. Instead, with regard to a feminist research principle about empowerment, a potential participant would feel much safer sitting in an audience with many others while I would be standing "exposed, alone and vulnerable" in front of them. Thus this method of presenting at conferences and meetings could empower possible participants - more so as they could challenge me with questions!

One such goal occurred when Sarah, the director of a support organisation, attended a presentation I gave at a conference in the region where she lived. I felt it was important for Sarah to attend as she not only had every right to learn more about my research, but I hoped that enabling her to attend may provide access to possible participants from her organisation. However, at the same time I felt nervous that Sarah, herself a mother of two children with $\mathrm{CAH}$, would hear arguments raised by me - arguments that she may strongly disagree with. Several members of the audience raised questions which I responded to - again I was fully aware that Sarah may disagree with my responses. About a month later Sarah contacted selected members of her organisation, whom she believed would be suitable participants. I eventually received e-mails from three mothers of intersex children and Lisa whom I later visited and interviewed. One mother I visited had her adult daughter unexpectedly present (a bonus for me) - whom I also interviewed, and remarked that as the interview was about her daughter she wanted her 
to be present. Indeed, Maguire's argument that "building trust takes time" (Maguire, 2008, p. 424) resonated strongly with my experience of seeking participants.

\section{Conclusions}

Lee's comment about sensitive research being a "threat of sanction" raises a language issue - hence stigmatising "labels", in that some intersex people find the term "intersex" offensive. The Transgender Inquiry by the Human Rights Commission, which included submissions from intersex people, noted that they held wide-ranging views about gender identity and sex anatomy. While some intersex people had gender identities that were neither male nor female (such as intersex and genderqueer), others firmly identified as male or female (HRC, 2007, pp. 80-81). Therefore, drawing from Raymond Lee's comment about "threat of sanction", some intersex people may have felt that participating in my research would put them at risk of stigmatisation.

The issue of language - particularly appropriate language - also relates to feminist theoretical perspectives. Postmodern feminists would like to see the male/female binary code dismantled with regard to a person's right to gender fluidity, which relates to Holmes' (1998, p. 221) assertion (in chapter 7) that surgery denied her the right to not only a queer identity but a queer culture and community. On the other hand, second wave feminists argue that dismantling gender binaries weakens feminist analyses of inequalities between men and women (Whelehan, 1995, p. 202). In relation to Jeffries' (1994, p. 100; in ibid., pp. 206-207) argument, a solution to women's oppression should not be the erosion of their female gender identity - as if female identity is bad.

While feminist research methodology raises issues of inequalities and power relations between researcher and participant, Portelli's (1991, p. 48), oral history theoretical perspectives raise the same issues between hegemonic (so-called legitimate) written sources (medical texts, for example) and the voices of individuals. Perspectives about research on sensitive topics therefore highlight the importance of empowering participants, as interviews may incur memories of traumatic experiences. Consequently, I ensured that counselling and support services would be available to participants. 
Aside from theoretical perspectives on oral history, I suggest that the key reason why I could not find a greater number of intersex participants is New Zealand's small population - hence the issue of confidentiality. Living in New Zealand may have made some intersex people all the more hesitant to participate in interviews - that remaining anonymous could be difficult. Some also may have been trying to rid themselves of unpleasant pasts. Clare Matheson (in chapter 2) remarks that New Zealand's small population makes it "difficult" to "rid oneself of the past" (Matheson, 2009, p. 57). Some years after the Inquiry, while studying art at Auckland University of Technology (AUT), Matheson discovered that the lecturer of an option she chose was Professor Green's daughter (ibid., p. 57). Therefore, with regard to my research, some intersex people may have not wanted to risk being found out by former school peers or others whom they may unintentionally encounter - a common occurrence in the little village that is New Zealand. 


\section{Chapter 9: \\ Medical practice and management}

As well as medical texts, this chapter examines the medical management of intersexuality from the perspectives (via oral narratives) of specialist clinicians, nurses, people with intersex conditions, and parents of children with intersex conditions.

The first part of this chapter will discuss the first question that many people ask when a child is born - "Is it a boy or a girl?" - and the implications when this is not answered immediately. In relation to this I will discuss differing views about male/female binary sex assignment, particularly with regard to societal judgement and parents trying to protect their children from this. The following section about surgery and hormone administration will examine the availability of specialised surgery in New Zealand's small population base, and narrators' differing views about surgery. Finally, I will discuss views about support for parents who may be upset when their sense of normality has been disrupted ("have we got a son or a daughter?"), and concerns about children experiencing teasing and bullying. Throughout this chapter I will discuss a recurring theme-stigma.

\section{The first question: "Is it a boy or a girl?"}

Paediatric endocrinologists Nicholas D Barnes and Tim D Cheetham (1999) state two questions first asked by mothers of newborn children: "Is it a boy or a girl?" and "Is it all right?" (Barnes \& Cheetham, 1999, p. 980). Barnes and Cheetham state that parents become distressed when no immediate answers are given, and that parents later worry about what to tell family members and friends (ibid., p. 980). They also advise against registering the birth until the child's sex has been assigned (ibid., p. 980). Bronwyn, a mother of four adult daughters - the two eldest of whom have $\mathrm{CAH}$, strongly advises parents to "remain firm" against pressure from people asking about a newborn baby's sex - particularly in a small rural community in New Zealand:

\footnotetext{
"Be strong for the future's [sic] sake of your child because later on that child is going to grow up - in our case, in a very small community where everybody knows, and they will then have to face the fact that you said that you didn't know what sex it was, or you didn't know, or you announced male when it was female or whatever. And that child is going to grow up - unless you're going to move away - in that community. So stay strong - don't announce it. And for your child's future don't announce it - no matter how much pressure
} 
you get, because it will matter one day. At the moment, to you, well it may not matter, but in the future that child will have to face - and somebody will say, when you're at a very vulnerable age: "My mum said there was this story, when you were born you were a boy. Are you a boy?' So hold out, stick to your guns and don't announce it."

(Bronwyn, 2010, interview).

Bronwyn's comments and advice suggest that she wanted to protect her two eldest children from stigmatisation. This is because, I suggest, many people only recognise the categories of male and female and are simply unaware about gender fluidity and intersex conditions. Therefore, because of this unawareness, some people may regard changing sex as abnormal and something to be ashamed of, while others may simply regard this as strange. Bronwyn's comment about being asked a potentially personal question "at a very vulnerable age" also echoes the issue of silence - that intersexuality is something never to tell to anyone (Chase, 1998, p. 211). Thus, on hearing a rumour, a more vindictive person may believe that the person concerned has a secret and use this as a means of attacking (hence stigmatising) another person.

After being "assured" by their paediatrician that their second child was male, Bronwyn and her husband Murray placed a birth notice in their regional newspaper - including a name, "that we had a wee boy" (Murray, 2010, interview). However, despite their child being "born such a perfect looking male - apart from undescended testicles", Murray recalls how he and Bronwyn "were querying it a wee bit" (ibid.). A chromosome test was undertaken and two weeks later the result confirmed that their second child's karyotype was female $(46, \mathrm{XX})$ :

"They said that the chromosome test must be incorrect, so they repeated it. So we waited another two weeks, at which stage it came back female again"

(Bronwyn, 2010, interview).

Murray and Bronwyn recall their feelings about this waiting period, and give their advice to parents:

Murray: "So I guess from that, that was a pretty traumatic time when you've then got to tell your community - a close-knit community, that 'We've had a boy but now we've actually got a girl'."

Bronwyn: "A very small community - everybody knows everybody." 
Murray: "So that was hugely traumatic - especially for Bronwyn, and I guess both of us. So my advice to parents - if there's any ambiguity or possibility of - don't make any announcements until you've either done chromosome tests or whatever is appropriate."

(Murray \& Bronwyn, 2010, interview).

Murray's comment that the time of the confirmed test results was "traumatic", when he and Bronwyn had already publicly announced that their child was male, suggests a lack of awareness about intersexuality as many people only acknowledge two sexes.

Information on their children's conditions, particularly during the time when their two eldest children were born, may have not only been scarce but difficult to access. Visiting a library (the internet was non-existent then) in the nearest town - a considerable distance from their farm - would have been difficult because of Murray and Bronwyn's busy roles as farmer and mother of two then small children (she now farms alongside her husband) respectively. Murray's comments emphasise the need for readily-available information resources - particularly for parents - and education about intersex conditions (see chapter 12). While Bronwyn comments on "what a corny society we live in" and that "we are all on a [gender] continuum anyway", she maintains that society's pressure to be male or female is especially reinforced during childhood:

\begin{abstract}
"If you are growing up within our society as a child - as an adult you can say 'It's not an issue', as a child you can't. As a child you're wearing a girl's school uniform or a boy's school uniform - you can't wear one or the other, you can't sort of mix it, you have to be one or the other. Every single child in New Zealand - and when they are growing up alongside other little children, every child knows that everybody's either a boy or a girl. Children are black and white. Adults can be grey as much as they want to, but children are not."
\end{abstract}

(Bronwyn, 2010, interview).

I would argue that the pressure to be strictly "boy or girl" is particularly strong during childhood in New Zealand and similar societies because of their upbringings in which, as Walter observed (Cochrane, 2010), some parents create social environments where boys and girls are clearly defined - Action Men and cars for boys, dolls and pink clothing for girls (ibid.), for example. Children, I suggest, also regard adults (particularly teachers and parents) as authority figures who are "always right" and develop perceptions from other sources, such as television programmes and books in their school library. While I have encountered children's books which feature lesbian (Lesléa Newman's Mommy, Mama, and Me), single (Jeanne Warren Lindsay’s Do I Have a Daddy?) and divorced parents (Claire Masurel's Two Homes), and children with 
disabilities (Eliza Woloson's My Friend Isabelle, about a girl with Down syndrome), I have never yet encountered a children's book about a child with an intersex condition. This, I suggest, is because of the silence and stigma surrounding genital ambiguity, particularly when the first question ("Is it a boy or a girl?") cannot be answered immediately.

Sheryl, a registered nurse who specialises in diabetes and endocrinology, says that the time when children are first diagnosed with intersex conditions is "often the most stressful time" for families:

"If I look back at the most recent family that we had diagnosed, it was their fourth child. They went through all the scans, been told it was a boy - most excited because they had three other girls. Had this baby - 'Yes, you've got a lovely boy.' An hour later, got looked at by a paediatrician - 'Ooh no, I don't think you've got a boy.' They were in a different hospital, so they have been transferred to [another hospital in region]. So by the time our doctors and our team actually got to see them, as you can imagine the family were incredibly stressed: 'Well what do you mean - do we have a boy, do we have a girl? What have we got?"'

(Sheryl, 2010, interview).

Sheryl recalls that there was a delay of "about 12 to 14 hours" before the family received information about what their child's condition may be:

"And then of course we still had to get genetic testing back to see what the DNA was, before we could actually give them a true answer."

(Sheryl, 2010, interview).

Sheryl's current caseload is "about 30 children with CAH in total" at the regional public hospital she is based at and that, if she is available, she will often meet with families when their children are first diagnosed (ibid.). This is not only to teach them practical aspects such as testing using Guthrie (filter paper) cards, but to offer them support:

"I guess it's [children's diagnosis] a stressful part of the job, but it's also nice because when you do meet families under those stressful situations you actually do get a really strong bond with them. Obviously you've still got no answers, and certainly my knowledge from this side is different from the doctors - that I'm not there to pass on the knowledge, but I'm often there just to reiterate exactly what's been said. Our team is especially good at actually putting things in very plain English, and not talking medical jargon and talking down at families. There is the expertise and they're really good at it. But often they [families] do still find it's easier to talk to a nurse because we're not up there on a pedestal - you know, about silly things or asking the same question again 20 times... or even just sitting there in silence and giving them sympathy."

(Sheryl, 2010, interview). 
Sheryl's comments that families prefer talking to nurses rather than clinicians reinforces Coney's illustration of clinicians as “experts" (1988, pp. 234, 246), in which parents may also find some clinicians' use of medical terms intimidating. Sheryl's comment, that some parents repeatedly ask the same question, also reinforces that parents not only find nurses more approachable, but that they may be afraid of appearing silly in front of authority-type figures such as senior clinicians.

Aside from concerns about sex assignment, Professor Paul Hofman, a paediatric endocrinologist at Starship Children's Hospital and the Liggins Institute, ${ }^{52}$ is concerned about children's health - particularly preventable deaths - such as salt loss associated with CAH. Hofman comments that CAH is very common amongst Pacific peoples but that, because of screening processes in place, the health of Pacific children is better in New Zealand than in their (or their parents') homelands:

\begin{abstract}
"Lots of kids are dying in Samoa and Tonga of 'cot death' and undiagnosed CAH. There's no screening in the Islands, but of course conditions will get picked up with ambiguous genitalia. There are cases of severe CAH amongst Pacific peoples - they're dying. I suspect it's a founder effect due to the relatively limited gene pool, because of the small population of the Islands. But children get saved in New Zealand due to screening."
\end{abstract}

(P. Hofman, personal communication, 25 February 2010).

While Hofman comments on health instead of gender concerns, biomedical academic Professor Milton Diamond and psychiatrist Dr H Keith Sigmundson counter societal stigmas associated with intersexuality. They state that their information sources include not only "trusted colleagues" but intersex people themselves, and advise clinicians to empower intersex people by not using terms such as "errors of development" or “abnormal” (Diamond \& Sigmundson, 1997, p. 1046). Instead, Diamond and Sigmundson advise clinicians to emphasise to parents (and their child) that intersex conditions are "biologically understandable while they are statistically uncommon", and that such children "are not freaks but biological varieties commonly referred to as intersexes" (ibid., p. 1046). Also, instead of using terms such as "normal", they advise clinicians to use terms such as "typical" or "most frequent" and to ensure "that the

\footnotetext{
${ }^{52}$ Starship Children's Hospital and the Liggins Institute are both located on Auckland Medical School's Grafton Campus (part of The University of Auckland). The Liggins Institute is a research centre that focuses on "foetal and child health, growth and development, breast cancer, nutrition, epigenetics and evolutionary medicine" (Liggins, 2010). The institute is named after Emeritus Professor Sir Graham Liggins, an "internationally renowned medical research scientist" who undertook pioneering research on the foetus and newborn (ibid.).
} 
parents understand that this condition is a natural variety of intersex that is uncommon or rare but not unheard of' (ibid., pp. 1046-1047). Diamond and Sigmundson advise that families, "as early as possible", should contact support groups for intersex people such as the Intersex Society of North America (ISNA) and PFLAG (Parents and Friends of Lesbians and Gays), as well as other groups for specific conditions such as AIS: "It is emphasised that one-to-one contact with another person having similar experience can be the most uplifting factor in an intersexed person's health development!" (ibid., p. 1048).

The implementation of Diamond's and Sigmundson's guidelines would probably alleviate the stress experienced by some families that Sheryl (2010, interview) commented on, when their children are first diagnosed with intersex conditions. Clinicians' use of medical terms may not only increase parents' stress but make intersex conditions appear more pathological ("abnormal"), particularly as some parents are not familiar with medical terms. Diamond and Sigmundson, on the other hand, use lesspathological language such as "biological varieties" and "rare but not unheard of" - thus they appear to advocate acceptance (as opposed to stigmatisation) of variations of sexual anatomy. Sheryl's obvious empathy with families, such as sitting beside them quietly and showing sympathy (Sheryl, 2010, interview), would also assist in alleviating stress.

\section{Sex assignment}

Barnes and Cheetham advise that individuals with $21 \alpha$-hydroxylase enzyme deficiency (the "classic" type of CAH as discussed in chapter 5) "must be reared in the female sex", regardless of virilisation, because of their "normal female" internal genitalia and the potential for fertility (Barnes \& Cheetham, 1999, p. 981). On the other hand, Barnes and Cheetham advise that the "choice of sex of rearing" for children born with an XY karyotype will depend on the child's external genitalia (ibid., p. 981). They recommend a female sex assignment if the phallus is very small and if there is an indication of "poor phallic growth" potential if the phallus does not respond to testosterone administration (ibid., p. 981). Another acceptable indicator for "female rearing" is a "vaginal cavity" revealed by a genitogram - especially if a cavity is a "reasonable size" to receive a penis 
(ibid., p. 981). Barnes and Cheetham's rationale for female sex assignment appears to be based on heterosexual assumptions: the assumption that a child with a vagina will, when older, want to have sexual intercourse (involving penile penetration) with men. In contrast, a mother of a primary school-aged child with CAH recalls being told by clinicians that many girls with CAH grow up to become lesbian (Anonymous 1, 2010, interview). While some parents may be worried about their child's future sexual orientation, the mother remarks that this is of little concern to her:

"...we also got told that quite a few CAH girls grow up to have female partners. I said to them [clinicians] that to me that would be the least of my worries, as long as my child grows up and she understands who she is, that she must take her medication every day, she must do heel pricks [blood tests] - that's all I'm worried about. If she comes home with a girl it just means I'll have two daughters, instead of a daughter and a son-in-law. You know, that is the least - and if she's happy with a female, hey, that's absolutely great. That's wonderful for her, yep."

(Anonymous 1, 2010, interview).

The fact that some girls (intersex or not) may grow up to become lesbian questions the supposed importance of early feminising surgery - particularly clitoral reduction surgery. As I argued in chapter 7, when a girl reaches young adulthood she may feel no attraction towards male partners and may not want a vagina. While she may not want to be penetrated during intercourse she may wish to penetrate her partner (with an enlarged clitoris) during intercourse. As Sal remarked (in chapter 7), her enlarged clitoris was merely offensive to societal prejudices (Sal; in Harper, 2007, p. 100) - a social stigma.

Professors of urology Giacomo Passerini-Glazel and Francesco Aragona state that at puberty nearly half of true hermaphrodites will have normal periods, hence they recommend assigning a female gender to such individuals, particularly those with 46,XX karyotypes (Passerini-Glazel \& Aragona, 1998, p. 286). Despite AIS individuals being infertile, Leon Speroff and Marc A Fritz claim that they are "certainly completely female in their gender identity" and advise that "this should be reinforced rather than challenged" (Speroff \& Fritz, 2005, p. 340). They advise that three factors should be taken into account when assigning a "correct sex of rearing": (1) future fertility, (2) the envisaged genitalia's appearance after puberty, and (3) whether the penis will be "adequate" for sexual intercourse (ibid., p. 354). However Deborah, a registered nurse who specialises in acute neonatal cases, thinks otherwise: 
"I say to parents, 'You're going to identify with the gender you are. Just because you've got a penis doesn't mean you're going to be a boy.' I think it's making that differentiation between your sex - physical sex and gender.

"Clinicians say to parents who have a baby born with ambiguous genitalia, 'We'll make the gender assignment that seems to best fit your child.' But I would say to any parent of a child in the neonatal unit, 'The gender you're assigned at birth isn't necessarily what you're going to identify with later in life.' And maybe that's a little more so for children with intersex [conditions]..."

(Deborah, 2011, interview).

Diamond and Sigmundson list specific conditions to "rear as male" and "rear as female", and that "true hermaphrodites should be assigned male or female depending on the size of the phallus" (Diamond \& Sigmundson, 1997, p. 1047). But they advise that, even when parents register the birth once sex assignment has been made, if the child's gender orientation "is in doubt" then parents may like to consider names for both boys or girls such as "Lee" or "Kim" (ibid., p. 1047). Bronwyn recalls the advice about giving her second daughter a unisex name soon after her birth:

"It was suggested to us we might like to call her [unisex name] ${ }^{53}$ - we didn't want to call her [unisex name], don't like [unisex name] as a name. One of the nurses said - we were tossing up between two names at that stage, and she said, 'Call her [girl's name] because it's the more feminine name, and that will grind into people's brains.' So we did and of course now we shouldn't have called [my second daughter] the most feminine name because she doesn't feel the most feminine girl! [laughs]"

(Bronwyn, 2010, interview).

Aside from concerns about stigma, Hofman comments that some parents experience grief over gender (P. Hofman, personal communication, 25 February 2010). A mother, herself with $\mathrm{CAH}$, had a child who was "misdiagnosed as a male" for the first three weeks of life by a paediatrician: "It was only when the screening test came through that we found out the child was a girl, the mother grieved for the loss of a son" (ibid.). Hofman says that parents' grief is even greater if an ultrasound scan shows ambiguity: "If you have female genitalia you're essentially a girl, but the child may become a boy" (ibid.). While Hofman's comments about sex assignment appear to be based on essentialist criteria for sex assignment (Stone, 2007, pp. 18-19) he does, however, acknowledge that gender may not match one's birth genitalia (Nataf, 1996, p. 18).

\footnotetext{
${ }^{53}$ As both Bronwyn and Murray requested that information from our interview be fully disguised I have withheld the names that she mentioned.
} 
Hofman claims that most children with the complete form of AIS (CAIS) "identify as girls" whereas the partial form of AIS (PAIS) is "more common and much more difficult to manage, as the brain has perceived androgen and [that] the gender identity of the child is more variable" (P. Hofman, personal communication, 25 February 2010). He also cautions that "many disastrous cases of removing gonads" have occurred (ibid.). While Hofman appears to acknowledge gender fluidity with his comment that gender can be "variable", his view about gonadectomy procedures appears to empathise with intersex people's experiences (in chapter 7), such as Briffa's (Bragge, 2005). Professor Spencer Beasley, Professor of Paediatric Surgery at Christchurch School of Medicine and a paediatric surgeon at Christchurch Hospital, comments on two cases (one PAIS and one CAIS) with regard to sex assignment:

\footnotetext{
"We recently had a child who was initially called by a girl's name and it became apparent that this child had partial androgen insensitivity syndrome, to a degree where the child would be better brought up as a boy on the evidence that we had. In fact we gave him a trial of some testosterone and he had very significant enlargement of his phallus, so we had quite good evidence that in all likelihood that this person would see himself as a boy subsequently. Now his older sister [aged "10 or 11"] also came to our attention, in part because of what was happening with her brother, but also she developed a complication of this particular condition. When we investigated further we found that she was 46,XY [male karyotype], had the same diagnosis underlying, but had a greater degree of androgen insensitivity.
}

"It was likely that her brain patterning was more likely to be more female, it was completely appropriate that she should carry on being female, and that is how she saw herself - that's how her family saw herself as well. When she gets to puberty - which is soon, she will see herself being female and so we have strongly encouraged her to continue as she is going. Even though her chromosomes say that she is male, in every other aspect she is female. So you do have to use good judgement based on sound principles when you're addressing some of these issues."

(Beasley, 2010, interview).

It appears that Beasley's recommendation, that the PAIS child should be assigned male, because of increased phallic size from testosterone administration, is based on Money's rationale (in chapter 4) on a trial test of androgens to determine sex assignment (Money, 1968, p. 45). His and Hofman's comments about the effects (or absence) of androgens on the brain also appear to be based on scientific (biological determinist) beliefs about genes-to-hormones-to-brain structure causing masculine or feminine behaviour (Rogers, 2001, p. 3). However, Beasley's encouragement of the girl to continue "being female" is a stark contrast to Greer's assertion (in chapter 2) that AIS women should not call themselves female (Greer, 1999, p. 70). While Greer conveys an essentialist view that women cannot call themselves women unless they possess an XX karyotype, and 
Morland argues against this in regard to social constructions of "femaleness" (Morland, 2006, p. 328), Beasley supports a child's right to call herself female regardless of karyotype or other so-called essential criteria.

\section{Surgery and hormone administration}

Both Hofman and Beasley appear to recognise that New Zealand's small population has implications on establishing specialised medical care for intersex conditions compared to neighbouring country Australia, which has a greater number of intersex diagnoses because of its larger population. Hofman asserts that there needs to be a multidisciplinary national team in New Zealand that focuses on intersex conditions:

\footnotetext{
"There is no clear group of people to refer to - we're trying to become a national service. I think we need to become a more formal group which will consist of gynaecologists, psychologists, surgeons and advocates."
}

(P. Hofman, personal communication, 25 February 2010).

With regard to New Zealand's closest, more populated neighbouring country, Hofman says that the clinical management model at the Royal Children's Hospital in Melbourne, Australia, is "one of the best around" (ibid.). Consequently he has been communicating with Garry Warne about his proposal of a national team (ibid.). Hofman comments that Royal Children's Hospital's multi-disciplinary team consists of a surgeon, an obstetrician and a social worker who, he says, is "phenomenal" and "does amazing work with the families" (ibid.). Hofman also claims that the surgery performed there on virilised girls with CAH is "excellent", with results of "near-normal genitalia", "very encouraging long-term outcome follow-up", and that the team gives much support and encouragement to parents (ibid.). Beasley is also keen for an Australasian-type team to be established:

"In practice, increasingly, our management of these children has been a combined service,
and we have involvement of paediatric endocrinologists and adult endocrinologists.
Paediatric ones are both from here and in Auckland and the surgeons are here in Australia,
particularly in Sydney and Melbourne. So the decisions are very much... you could almost
say committee decisions, but they're based on the expertise of quite a few people. We are
quite keen, and it may well be that these new changes to the health system are going to
facilitate that with the National Board being developed in the last year or so."

(Beasley, 2010, interview). 
The National Board is a 22nd District Health Board (DHB) created by the New Zealand government which, as Beasley describes, “covers those services where they don't fit into natural silos around the country":

\begin{abstract}
"We're hoping that with time we can develop a New Zealand service with DSDs, and we're working at that behind the scenes at the moment which will be multi-centric, probably primarily based at Starship [children's hospital] in Auckland but with significant input from Christchurch and probably from Wellington and Hamilton as well - we hope! And that we will be able to better configure the service so each of these patients are treated by the service and not by two individuals. So it can guarantee a much higher overall quality of care for any new family that comes."
\end{abstract}

(Beasley, 2010, interview).

Like Hofman, Beasley and his colleagues have also been liaising with their counterparts in Australia because of its greater population: "they have as many if not more problems than we [in New Zealand] have at this moment with the management of DSDs":

"I wouldn't be surprised if it expanded to form an Australasian group in due course. So at a medical level we're trying to get things in place so that we have access to the best level of expertise of a group of people that have a specific [involvement] in it, and can be involved in ongoing training and CME [Continuing Medical Education] activities to make sure that they remain at the cutting edge."

(Beasley, 2010, interview).

In their "Consensus statement on management of intersex disorders" (2006), clinicians Ieuan A Hughes, Christopher P Houk, S Faisal Ahmed and Peter A Lee advise that surgeons are responsible for outlining surgical stages and "subsequent consequences from infancy to adulthood", and that only those "with specific training in the surgery of DSD" should perform such procedures (Hughes et al., 2006, p. 556). Hofman says that outcomes are "very good" if a surgeon performs particular procedures many times and cautions that, if a surgeon only performs procedures one to two times per year, then there is a cause for concern - thus a surgeon needs to "regularly practise" (P. Hofman, personal communication, 25 February 2010). Sheryl also says that the surgeon should be "an expert" and that a few general surgeons have offered to perform such surgery in New Zealand:

“Our specialists would not advise anyone who hasn't had many years of experience to be allowed to do some corrective surgery, because it has such a huge influence on whether they [intersex people] have any feeling or sensation down there as an adult."

(Sheryl, 2010, interview). 
Sheryl offers support to families "through the process" of awaiting "corrective surgery" for female-assigned children which involves obtaining funding for a specialist surgeon to travel from Melbourne to New Zealand (ibid.). She comments that the type of support given to parents depends on male or female sex assignment:

\begin{abstract}
"...because when you do have a very virilised female - that their clitoris is two or three centimetres long and it does look like a penis - seven or eight months down the track they're [parents] still doubting that the doctors have got it right, because the anatomy of this child looks like a male. And you're getting them on the phone going, 'Well they couldn't find a vagina in the scan - it has to be a boy, it looks like a boy.' There is all that kind of emotional thing going... and going back and double-checking that the DNA is correct and the genetic screen is right - even though you know that it was done and the parents have been told. But not kind of just saying, 'We've done this, we've told you' - you've got to say, 'Look, let me go back and recheck it for you.' And that makes a difference."
\end{abstract}

(Sheryl, 2010, interview).

Like Bronwyn and Murray, I do not wish to dismiss the stress that some families experience surrounding their children's sex assignment. However, Sheryl's comments indicate that many families, like the majority of New Zealand's population, are simply unaware of intersex conditions. As discussed previously, her empathy towards families experiencing stress shows from her willingness to recheck karyotype test results. Sheryl then comments on reasons for not delaying genital surgeries:

\begin{abstract}
“They've got toddlers walking around that now look very, very different from their peers, and they're going to be getting to an age that if it's not done soon they're actually going to be aware of that. Whereas in an ideal world it would be done before they're 12 or 18 months so they're not going to be conscious that they are different from the other girls... it's very different from a three-year-old. A three-year-old is very, very aware that 'girls have this and boys have that', and certainly from the parents' point of view those have been their main concerns as to the surgery being delayed."
\end{abstract}

(Sheryl, 2010, interview).

\title{
Mr Brendon Bowkett, a paediatric surgeon and paediatric urologist at Wellington
}

Hospital, also believes that surgery should be performed earlier rather than later "so that the child at one year of age won't remember any trauma" associated with surgery - thus he will not, for instance, operate on an adolescent girl to create a vagina (B. Bowkett, personal communication, 25 February 2008). Deborah, however, thinks differently:

"I think the thing we really try to push is you don't have to make any decision fast - apart from CAH where you have to look after the medical side. You don't have to make any decisions fast, and that's what I try to convey to parents. But I also know with CAH girls that once they hook into the system then the pressure is on to get that surgery done before a year."

(Deborah, 2011, interview). 
Deborah, who has talked to many parents of CAH children, further comments that even though some parents understand why others are against genital surgeries on intersex children, they will still consent to the procedure for their children - particularly for "virilised" girls:

"They get to Melbourne [Royal Children's Hospital], they talk to the medical staff there, they see 'before' and 'after' pictures and they make that decision."

(Deborah, 2011, interview).

Genital surgery for "severely masculinised" genitalia involves reduction of the enlarged clitoris and creation of a vagina, and urologist Giacomo Passerini-Glazel outlines a single-stage surgical procedure for female pseudohermaphrodites in a Journal of Urology (1989) article. The technique involves reducing the size of the enlarged clitoris by "degloving" (cutting the outer skin of) the phallic structure to expose the corpora cavernosa ${ }^{54}$ which are then ligated and cut (Figs. 1, 2, 4; in Passerini-Glazel, 1989, p. 565). After previously being separated from the tips of the corpora cavernosa, the glans (also reduced by "cutting out two triangular wedges") containing the neurovascular bundle is then reattached on top of the now-shortened corpora cavernosa (ibid., p. 565). The urogenital sinus (tube-like structure located underneath the corpora cavernosa) is then "incised dorsally" to create a flap which is attached to the phallus' outer skin (cut into two flaps during the "degloving" process), which is then formed into a cylinder-like structure to become the vagina (ibid., pp. 565-566). The newly-created vagina is then drawn into a surgically-created opening into the perineum (ibid., p. 566). PasseriniGlazel believes that clitoral reduction is "an important step" as the clitoris may enlarge "up to the size of a normal male glans" (ibid., p. 567).

In contrast with Bowkett's view, Passerini-Glazel advises that vaginoplasties should not be performed till children are older as, due to the vaginal opening's tendency to become narrow, regular dilation is required (Passerini-Glazel, 1989, pp. 565-567). Sarah, a director of a support organisation for parents of intersex children, also comments on the "difficulty" of undertaking vaginoplasties on children at a very young age:

"One of the difficulties on doing vaginoplasties on very young girls - and it's another argument against doing the procedure, is that it really needs to be followed up with dilation

\footnotetext{
${ }^{54}$ Corpora cavernosa (singular: corpus cavernosum): a pair of cylinder- and sponge-like structures which form the erectile tissue in the penis and clitoris (Oxford, 2003, p. 160).
} 
work. So girls need to be provided with a set of dilators and they need to be shown how to work them, and they need to use them regularly. Well, a nine-10-11-year-old is not going to do that. A parent can't do that with an infant... you just can't. So you've got to wait till a child, a girl, is old enough and comfortable enough touching their bodies and knowing their bodies - using a tampon, for example - before they can use dilators."

(Sarah, 2010, interview).

For intersex conditions with associated hypospadias, Hughes et al. advise that clinicians should consider the "complexity" of a phalloplasty procedure during adulthood when counselling individuals whose gender assignment "is dependent" on this (Hughes et al., 2006, p. 557). However, for "undermasculinised males" with varying degrees of hypospadias and amounts of erectile tissue in the penis, they advise that a "feminising as opposed to masculinising genitoplasty" procedure entails less surgery in order to "achieve an acceptable outcome and results in fewer urological difficulties" (ibid., p. 558). Plastic surgeon Chris McEwan remarks that surgical construction of a penis is "bloody difficult" and that he has "never seen a functional penis satisfactorily constructed" (McEwan, 2010, interview). Instead of a phalloplasty procedure McEwan advises most female-to-male transpeople, for instance, about using a prosthetic penis:

\begin{abstract}
"I really think they do better with prostheses. They're more realistic, they can be more useful, they've got more options, it can be part of their [sexual] play - if you like, whereas a lump of meat sitting between their legs - it has nothing other than the fact that pee comes out of it."
\end{abstract}

(McEwan, 2010, interview).

Bowkett states that hypospadias is "not an intersex condition" as the "hundreds" of hypospadiac children he has operated on "think they are boys" (B. Bowkett, personal communication, 25 February 2008). However, Rogena feels otherwise as s/he describes hirself as an intersex person, who at the ages of four and 15 had surgery for hypospadias. I ask Rogena if clinicians or nurses ever discussed hypospadias or the actual procedure, prior to the second time when s/he was of an age to become involved in the decision-making process:

\footnotetext{
"Not that I remember. Because when I read your [interview] question I was trying to think, 'Was I actually ever told what it's all really about?' The only thing I can think maybe they might have said was, 'We're trying to clear out this scar tissue.' That's the only thing that I can remember, is they talked about the scar tissue. But apart from that, that's all.
}

\footnotetext{
${ }^{55}$ Similarly with others who identify somewhere in between the male-female spectrum, as Rogena describes hirself as "not as male, not as female" (Rogena, 2011, interview) I have used the pronouns $s / h e$ (pronounced "see") and hir (pronounced "here") (Feinberg, 1998, p. 1). I consulted with Rogena about these pronouns at our interview.
} 
"All I was told is my condition was hypospadias, and that's very clear - you can see on the penis where that was cut open. But I don't know whether it's - well I know it's more than the tip, I know it's much further down than that. But whether it was close to the base, whether it was half-way up I have no real idea. I also consider if it is that important in my life, and I think no. Whether it's mid-shaft or end-of-shaft is not an issue, I am who I am that's it, full-stop."

(Rogena, 2011, interview).

I then ask Rogena, when s/he was four or younger, if clinicians ever advised hir parents the name of hir physical variation. Again in contrast to Bowkett's comment, during childhood Rogena did not think s/he was a boy:

\begin{abstract}
"I think they were told the name, but never the causes and what made it happen. They were never told that there are other effects to it, nothing like that was ever told. So when you wake up at nights thinking, 'God, wake me up a woman, wake me up a girl in the morning,' you never know why you have those kind of thoughts. It's just one of those things you just live with and keep quiet about your whole life. But if my parents knew that was going to happen, maybe they might have allowed a bit more fluidity. But you just assume that you have to grow up a certain way, because that's the way you've been pushed."
\end{abstract}

(Rogena, 2011, interview).

A mother consented to genital surgery being performed when her child was aged "two or three" (Anonymous 1, 2010, interview). She said that she "personally wanted" the surgery to be performed as she felt it was in her child's "best interests":

\begin{abstract}
"I know how kids are cruel, and I didn't want my child going to school and, for example, getting changed for sports, swimming, and girls going, 'Oh she's different'. Because when you looked at my child, she didn't have anything like a vagina, it looked like she had an oversized clitoris. And they referred to that as a stalk, so it looked about that big [indicates length of about two centimetres with forefinger and thumb]. But it was big enough that if other girls looked at it they'd be like - you know how kids sort of stare and go 'Ohhh!' [imitates emphasised shock], start pointing and start getting cruel. Kids can be nasty. I'd be heartbroken if my child came home crying saying, 'They said I was...' - whatever horrible things kids say."
\end{abstract}

(Anonymous 1, 2010, interview).

With regard to children being bullied or teased because of differences, Bowkett comments that it is "very difficult socially" when considering a scenario of a 12-yearold girl with CAH "running around with a penis" (B. Bowkett, personal communication, 25 February 2008). However Jo, a mother of an intermediate school-aged child with CAH who has not undergone surgery, thinks differently. She remembers being given a videotape on severely virilised individuals: 
"So we have these anticipations of our daughter growing to be as unfortunate as these other poor children. Everything seems to focus on the worst case scenario, and there's no balance in between."

(Jo, 2010, interview).

With regard to the Prader stages of virilised genitalia (Hughes et al., 2006, pp. 557), Jo, whose daughter was diagnosed at 10 days old, recalls:

\begin{abstract}
"When they measured her clitoris there was a lot of humming and haarring [sic] - there was no vocalisation of what was going on. We didn't know what the normal standard was - how much larger her clitoris was in other babies of her age, we had no understanding of that. And that was really concerning, just because we know there was a slight virilisation of our daughter's genitals, but how far is it? Is she at the top grade, is she near the middle... that kind of clarification would have been really good."
\end{abstract}

(Jo, 2010, interview).

I ask Jo about the type of advice or support she considers should be available for parents, who may be concerned about their child being "neither a boy nor a girl". Jo gives her thoughts about genital surgery and support, including times when her daughter has been teased:

\begin{abstract}
"That's a very difficult one because there's no gender difficulties in the fact with my daughter, but there are some physical things that I've had pointed out to me by incredibly stupid [emphasises this] people. Because my daughter's clitoris is slightly more distended, when she was running round as a toddler with knickers on, and when she wanted to go to the toilet it would harden a bit and you'd see it. And she's been teased about it at school. All I can say is give the children as much information as they can deal with at that time, and love them. And that is the huge thing.
\end{abstract}

“Our endocrinologist's talked to me - I've asked him about my daughter, and he said, 'Well what we can do is, if you want, we can actually shave the size of her clitoris and bring it down, and stitch it up so it'll be smaller.' And I said, 'Well how will that affect her physically?', and he said, 'Well she'll lose sensation.' And I [laughs] - because I'm so mean to our endocrinologist! I said, 'Honey, you guys have enough trouble finding it so maybe if hers is a bit bigger it'll be better.' And he just blushed bright red! [laughs] But I said to him, 'That's not going to happen.' I spoke to my daughter about it, when she's come to me and somebody's made a comment. I've said to her, 'Sweetie, it won't matter. It doesn't matter at all.'

"I said to her, 'At this stage I'm not going to explain how important that is for you in your life, but you will realise as you get older. But if you ever want to do something about it we can do something about it, but be aware that it will affect your life for the rest of your life."”

(Jo, 2010, interview).

Bronwyn describes the effects of genital surgeries on her two adult daughters with $\mathrm{CAH}$ :

"We sought second and third opinions from as far afield as we knew, and kept asking those we were talking to seek their own counsel. So surgery for our girls was undertaken after being discussed with medical professionals from throughout New Zealand, Australia, 
England and elsewhere in the world. We proceeded only after we were satisfied that the very best results would be achieved. In retrospect, in today's world, the surgeries would be deemed quite catastrophic. That is now but this was then. I insisted on knowing that the surgery was firstly - necessary, secondly - necessary at the age the child was at, and thirdly - would achieve a final result that would give them a fully functioning-in-every-way female anatomy. Assurances were given on all counts. Many 'final' surgeries and much distress later, the results have proven mediocre and unacceptable."

(Bronwyn, 2010, interview).

Sarah Creighton, from the Elizabeth Garrett Anderson and Obstetric Hospital University College London Hospitals, comments that after a "one-stage" genitoplasty procedure further surgeries at adolescence are often necessary, such as allowing tampon use, and advises that families "should be prepared for this" (Creighton, 2004, p. 45). A study undertaken at University College London Hospitals, of adolescents and adults who had had feminising genital surgeries, suggested that "cosmetic surgery to the clitoris does not ensure improved adult sexual function and indeed might cause damage" (ibid., p. 45). Preliminary results from another "project on sensitivity testing" showed "markedly impaired sensation" in adult women with $\mathrm{CAH}$ who had undergone feminising surgeries (ibid., p. 45). David Thomas, from St James' University Hospital in Leeds, advises that surgeons "have a duty to warn parents" about the risk of loss of clitoral sensation from feminising procedures (including one-stage procedures) and about further "necessary" procedures during the child's adolescence (Thomas, 2004, p. 50). Diamond and Sigmundson also advise against performing surgery for "cosmetic reasons alone", except if the condition is affecting physical or medical health, and that clinicians should tell parents that their child's appearance, though not like other children, "may be of less importance" than the sexual function and erotic sensation of the genitalia after puberty (Diamond \& Sigmundson, 1997, p. 1047). They also assert that surgery "should typically wait until puberty or after puberty, when the patient is able to give truly informed consent" (ibid., p. 1047).

Intersex activist Mani Mitchell believes that if genital surgery was made illegal in New Zealand it "would be catastrophic for some family situations where the parents can't cope with that", and that "very wealthy people would simply take their children and have those surgeries performed in countries where that's available" (Mitchell, 2010, interview). I ask Mitchell about the type of advice or support that should be offered to parents, who may be upset that their child is "neither a boy nor a girl": 
"One of the things that Cheryl [Chase] worked out very early on, and I support absolutely, is the world that we live in by far and a majority is a binary world. So a child needs to be assigned a gender - male or female. It shouldn't be a guess, it should be based on the evidence that's available. But again the gift from transgender people, that designation is given with gentleness for all children with something like 'this will need to be confirmed later on by the child'. We know absolutely from transgender children that if the designation doesn't fit with the person's own internal sense of self - this in itself is not catastrophic. The child can change that later on, which leads me to the issue of genital surgery because one of the problems with genital surgery is it's non-reversible. ...there's an American surgeon who said very beautifully: 'We shouldn't take away from the child anything that that child may want later'."

(Mitchell, 2010, interview).

While some assert that genital surgery should be performed at a young age, Sarah believes that more research should be undertaken on its later consequences. Her comments resemble Creighton's (2004, p. 45) and Thomas' (2004, p. 50) findings:

\begin{abstract}
“A girl who's a five [Prader stage of virilised genitalia], and I know a number of women who've been a five, will probably end up having successive surgeries. ... Who then says to the child - sits down when the child is $18,19,20$, perhaps becoming sexually active, perhaps not, at 25 - is this working?

“How do you feel... like, 'does it work... does your vagina work?' It's not really the right question but, 'How do you feel in your own skin? How do you feel when you're in bed with somebody?' Whether you are attracted to male or female or both...”
\end{abstract}

(Sarah, 2010, interview).

For female-assigned individuals with the complete or partial form of androgen insensitivity syndrome (CAIS and PAIS respectively), Hughes et al. advise removal of the testes with subsequent oestrogen replacement therapy to prevent them becoming malignant during adulthood (Hughes et al., 2006, p. 557). However, they advise delaying an orchidectomy procedure until an individual has reached adolescence, considering that the earliest reported case of malignancy was when the CAIS individual was 14 years old (ibid., p. 557). Hughes et al. recommend a testicular biopsy procedure at puberty to test for signs of malignancy such as carcinoma in situ (ibid., p. 557). If the test result is positive, Hughes et al. advise on the option of banking sperm before undertaking a "local low dose" of radiotherapy treatment (ibid., p. 557). Mitchell challenges medical rationale for removing gonads because of the supposed risk of cancer:

"Well, if that was followed with the general population then every female child would have their breasts removed - I mean, it's just silly. What seems to me that would be more appropriate would be that the person would be given the information as a teenager, so that they actually understood their own medical condition and that they knew that there were certain things they would need to watch out for or have checked as they went forward. So 
that they wouldn't have parts of their body removed on the off-chance that they might develop cancer - it would be their choice."

(Mitchell, 2010, interview).

With "impaired" gonads (such as resistance to androgens, as with AIS), Hughes et al. advise about inducing puberty with hormone administration "to replicate normal pubertal maturation to include secondary sexual characteristics", growth and bone mineral density, "together with psychosocial support for psychosexual maturation" (Hughes et al., 2006, p. 557). For male-assigned individuals testosterone is commonly administered via injection intramuscularly, whereas female-assigned individuals "require oestrogen supplementation to induce pubertal changes and menses [periods]" (ibid., p. 557). However, Diamond and Sigmundson advise that informed consent should be obtained for hormone administration (except for $\mathrm{CAH}$ ), as many intersex people felt they were not informed about hormone use and were not happy with the results (Diamond \& Sigmundson, 1997, p. 1047). While providing hormone administration to ensure growth and bone mineral density is important for an individual's health, like Diamond and Sigmundson I argue that individuals, before reaching puberty, should be fully informed about the results of hormone administration: for example, that oestrogen promotes breast development and testosterone promotes irreversible deepening of the voice. Clinicians such as paediatric endocrinologists should, I argue, discuss details about hormones before pubertal changes occur and, most importantly, ask children questions such as "What would you like to look like when you get older?"

My argument draws from people's experiences such as Briffa's (in chapter 7) who "repeatedly" told clinicians that he did not want to develop breasts (Bragge, 2005), which proves that some children (who underwent a gonadectomy and were initially assigned female) may not want to undergo a feminising puberty with breast development. With regard to induced menstruation, my point is that, from previous conversations I have had, some girls and women dislike having periods as they literally find them a bloody pain. Aside from menstrual cramps and bleeding, some also consider having to regularly buy tampons or sanitary pads a nuisance and extra cost to their supermarket bill. Indeed, when I lived in the United Kingdom, a then work 
colleague told me she thought that the British government should fully subsidise tampons on the National Health Service (NHS)!

Hofman questions surgery with regard to conditions such as late-diagnosis $\mathrm{CAH}$ and PAIS, and acknowledges that some individuals may have fluid genders:

"I avoid surgery as the gender identity can be very difficult to define in infancy. ... By age three to four years old children identify with their genitalia - what's there and what's not, you want to strengthen their gender identity. But with kids who have fluid gender identities, permanent early surgery such as removing tissue and gonads is not acceptable in this day and age."

(P. Hofman, personal communication, 25 February 2010).

Bowkett also remarks that when you examine a neonate with ambiguous genitalia "you cannot tell what the gender will be" (B. Bowkett, personal communication, 25 February 2008). In this instance Bowkett and his colleagues will try to find out as much as possible about the child's anatomy while emphasising that "we do not do destructive surgery", including with cases of "moderately" to "severely" virilised children (ibid.). He will also not "over-medicalise" children (in terms of seeing them frequently) as, he says, "you don't want a 15-year-old committing suicide" as children may think "there's something wrong with me" (ibid.). Bowkett thus shows concern about individuals feeling stigmatised, and comments on a cultural comparison: a Samoan couple may be "easier to deal with" as they may have a possible fa'afafine child, whereas a European couple "may be more difficult" (ibid.). This not only suggests that Samoan communities may be more tolerant of gender fluidity than Euro-Western communities, but that uncertainty about sex assignment is less of a stigma in the former than the latter.

\section{Support-peer and social issues}

McEwan remarks that parents of intersex children "no doubt" need support right from the very beginning “when their paradigm of 'have I got a boy or a girl?' is suddenly shaken up":

\footnotetext{
"They need support that starts with understanding what they're feeling, understanding what the child is likely to go through, understanding the sorts of decisions that are going to have to be made and which the child will not be able to make for his or herself for a lot of years."

(McEwan, 2010, interview).
} 
Like Hofman and Beasley, McEwan believes that a multi-disciplinary effort is required involving a paediatric endocrinologist, a family therapist, a social worker and "somebody who understands what resources might be needed and how they might access them" (ibid.). McEwan comments on a question of when to establish a gender: whether a child should be brought up "somewhere in the middle" of the gender continuum, whether a child should be brought up as male or female or whether, for instance, it may be "easier" for the child to be assigned female:

\begin{abstract}
"I don't think we've got the knowledge yet by any stretch of the imagination. We know we've done things wrong, that's easy to find, and always it's easy to do.

“But I don't know anybody yet who's come along and said 'but if you [do it] this way you get happier people'. I know you can say, at the moment, 'the way you did it then you've got a lot of unhappy people'. Yep, fair enough. But I haven't yet seen anybody who's come along and said, 'Well it's OK to raise somebody without a concept of gender to the age of 15 ', when they get to decide for themselves. And so then at 45 we've gone back to them and said, 'Was that the right thing to do?'... And until you do that you can't really say that. We know there are a lot of problems, but to be honest I think there were always a lot of problems. There wasn't an easy way to do it - there isn't an easy way to do it."
\end{abstract}

(McEwan, 2010, interview).

McEwan advises that support needs to be considered "in the context it arises in" with regard to various families he had encountered (McEwan, 2010, interview). He says that, for some families, "the concept of a child not having a gender that they could identify was just completely destructive" in that their "only solution" was that their child "had to have a gender" (ibid.). McEwan also acknowledges gender fluidity as he believes that gender "changes with time" from talking to people of various ages on "the benefits or trials of being a particular gender":

\begin{abstract}
"Young children don't seem to have a distinction between male and female too much... Usually the males think the girls get a better time of it, the girls aren't too sure but they think they're probably OK. Then to late teens to mid-twenties I think it's more of a male world, I think there's a comfort - I think it drifts back to the female when a bit older, and so on and so forth."
\end{abstract}

(McEwan, 2010, interview).

McEwan then believes that while there are many intersex people whose "psychological gender has been out of kilter with [their] assigned gender at the time of the intersex decision", there may be other intersex New Zealanders whose assigned gender has been successful (ibid.). He recommends consulting with a wide group of intersex people, and asking them about times when their assigned gender "did work" and times when it “didn't work". McEwan also advises that individuals should have the ability of making 
choices (ibid.). Hofman too advises that both children and parents require support. His comments appear to indicate that, aside from adults, support for intersex children is lacking in New Zealand:

\begin{abstract}
"Most kids have come from outside Auckland and many kids have behavioural problems. We had one PAIS girl who was very violent - she wanted to cut people up... wanted to pee standing up, feels like she wants to be a he, the paediatrician said she wants to have a gender change. I think support is fragmented, no parents want the school to know their child is different, such as a cubicle or changing room situation."
\end{abstract}

(P. Hofman, personal communication, 25 February 2010).

With regard to undercurrents of societal prejudice amongst some parts of New Zealand society, Hofman then comments about intersex conditions associated with "major ambiguity" and that there is "ignorance in society, particularly amongst parents who feel isolated - they don't want to talk about it" (ibid.). His last comment appears to reinforce the implications of New Zealand's connectedness: the fear of a personal matter (which could be considered stigmatising) being found out by others. With regard to issues of ignorance and isolation, Jo comments on times when her daughter has been bullied at school for her physical variation:

"It's really - you just want to go to school and beat the crap out of these kids for that insensitivity, it just does my head in. But we will get bullied in moments of our life, whether it be for freckles or wearing glasses or - my girlfriend's six foot four and my best friend's six foot four, she was six foot two at 11 . So everybody gets bullied, it's how they learn to deal with it, and then make sure they don't allow it to happen to someone else. And I've said to my daughter, 'Every single person is different, nobody is the same, so you have to accept all these little differences in people."”

(Jo, 2010, interview).

But unlike Jo's daughter, despite having two procedures before she started secondary school, a young adult woman ${ }^{56}$ with $\mathrm{CAH}$ also encountered teasing for her supposed difference:

\begin{abstract}
"At the beginning of high school I got teased about being a 'hermaphrodite', and someone even asked my brother if I was a 'hermaphrodite'. It did get to me, but I felt that I needed to be strong and just let them do it because if I react then they're going to get a reaction they're going to get the reaction they want. But if I don't then they'll go away, and it soon did disappear after a while. So that was the only trouble I had at school."
\end{abstract}

(Anonymous 3, 2010, interview).

\footnotetext{
${ }^{56}$ As the woman requested that information from our interview be fully disguised I have withheld her exact age.
} 
With regard to hospital environments, Hughes et al. warn against taking medical photographs that can provoke feelings of shame and trauma (Hughes et al., 2006, p. 558). They advise that, while photographs can be appropriate for medical records and education, they should be taken when an individual is "under anaesthesia for a procedure and with appropriate consent" (ibid., p. 558). A mother (Anonymous 1) recalls her discomfort when medical photographs were taken soon after she gave birth:

"They said to me, 'Look, can you get us photos?', which I wasn't very keen on. I think it
was how it was done, because they came in, and my baby was like, probably a day or two
old, and they held her legs down and took photos, and it just... it was a bit much. It was just
awful, and they said, 'Oh, but we need the photos so we can see the genital region.' I don't
know if they're still on her file, but I think I may have asked that they actually be destroyed,
because I didn't want those sort of photos on her file."

(Anonymous 1, 2010, interview).

The mother's discomfort resonates with intersex people's experiences in chapter 7, such as Triea's (Holmes, 2002, p. 169) recollection of being photographed and feeling "like a lab rat" during examinations. The clinicians' treatment of the child, though possibly unintentionally, was akin to a medical subject instead of a human being. While the child was only a few days old and could not possibly remember this experience, and though the mother was not photographed herself, her feelings of witnessing her child being treated as a research object nevertheless matter. The mother's feelings towards the sensitive nature of the photographs - that she did not want them on her child's file also questions the necessity of taking photographs for supposed medical purposes. However, while medical photographs may be useful for clinicians in terms of diagnosis, the mother's experience emphasises the importance of sensitivity towards an individual's wishes and feelings.

\section{Conclusions}

Debates about genital surgeries are a complex issue. While Creighton (2004, p. 45), Thomas (2004, p. 50) and Jo's endocrinologist (2010, interview) suggest evidence that such surgery can be detrimental to sexual sensation, Mitchell believes that making it illegal may be "catastrophic" to some families' emotional states (Mitchell, 2010, interview). Her comment that some families “can’t cope" with ambiguous genitalia resonates with Jordan's (in MacKenzie et al., 2009, p. 1778) childhood recollection in chapter 7: that parents' anguish and worry about not letting them out of their sight, in 
case someone may find out about their variation, may cause children to feel that "there is something bad about me". Thus parents, though unintentionally, may cause their children to feel stigmatised.

In countering feelings of stigma and symptoms such as isolation, I argue that parents who have difficulty coping with their child's physical variation must be offered support, not only from community/support groups such as Sarah's but educational material such as Leigh McCarthy's pamphlet (see chapter 12). Hofman's and Beasley's proposal of a national/Australasian team highlight the issues that clinicians, parents and intersex people encounter in New Zealand in which, because of its smaller population, the number of intersex diagnoses is smaller than in Australia. However, I argue that this proposed team should focus more on acceptance and education about intersexuality that it is not "bad" as a videotape conveyed (Jo, 2010, interview). Hofman's suggestion about including advocates (Hofman, personal communication, 25 February 2010) would assist in goals towards educating families, hospitals and others such as teachers who may encounter intersex children. In accordance with Hofman's concern about CAH screening (ibid.), the team should also include work on health concerns, as well as informing families and individuals about the risks of surgery (such as loss of sensation) and hormones.

Comparisons between Anonymous 3 and Jo's daughter, who have and have not undergone surgery respectively, is also proof that surgery is ineffective against teasing at school - particularly as Anonymous 3 underwent surgery before starting at a new school. Thus, while Hofman's concern about parents not wanting a school to know about their child's difference is understandable in terms of stigma, this highlights the importance of education about diversity and acceptance (see chapter 12), as Jo (2010, interview) commented on. The importance of support is highlighted even more by accounts of parents' experiences that are the focus of the next chapter. 


\section{Chapter 10: \\ Parents' experiences with "experts", hierarchies and empowerment}

Apart from midwives and obstetricians, parents are the first to know that their newborn child has an intersex condition or that the child's chromosome type is discordant with their genitalia. The first part of this chapter will examine the responses of parents when their children were first diagnosed. One mother experienced shock because of health concerns as her son's life was in serious danger. Other mothers experienced shock because of a lack of information about intersexuality: from my findings, the hospitals their children were born at had little or no encounters with intersex conditions. I will discuss whether some parents' shock, when some clinicians questioned their newborn children's sex assignment, was a possible consequence of New Zealand's small population where the number of intersex diagnoses is smaller. The second part of this chapter will examine issues of power in medical settings. As some parents recall, it was the nurses who were more supportive and open towards providing information - and empowerment - than clinicians.

\section{When parents received their child's diagnosis}

After Sarah's first child was born in 1986, she later founded a support organisation for parents of intersex children as there was no such support in New Zealand. She remembers a traumatic period when her son was diagnosed with $\mathrm{CAH}$ and became critically ill:

\footnotetext{
"When our first baby was born he became critically unwell in the second week of life and it was all bizarre really. Like most of these major life incidents, the initial response was one of incredulity and shock. I couldn't get my head around what was happening. So asking the same questions over and over again, not understanding, being pretty numb, confused. We were able to have our baby tested [with Guthrie cards], and his results for adrenal insufficiency came back sky high - like there was something seriously wrong... and he nearly died.
}

"Between that 24 hour period - between getting the test result, the GP turning up, looking at him, said he seemed alright. Well he wasn't alright - he was on the decline then, and us getting him into a hospital appointment, he was on death's door. We were fortunate that we were able to start treatment, and he was put onto IV steroids and fluid replacements and managed to stave off heart failure. We were in there for two weeks getting him stabilised."

(Sarah, 2010, interview). 
Sarah remarks that this period "was the beginning of a lifetime of regular hospital visits" and managing her son's medication, which involved administering a liquid form of cortisol and Florinef (medication to replace aldosterone): ${ }^{57}$

"In the early years of life one of the most stressful parts of course was getting this medication into him, because with babies they spill and they can't talk to you, they can't tell you they're feeling sick. Whenever he was sick we'd have to triple the dose. We had quite a number of hospital visits, we'd have regular blood tests. I would say it was traumatic really. It's not that people weren't genuinely nice to us, but the system back then was not child-centred, it wasn't user-friendly for families. I still don't think it does an overly good job sometimes with some of those things. But it was a hell of a lot worse back then."

(Sarah, 2010, interview).

Another mother (Anonymous 1) remembers when her child's initial sex assignment was questioned at less than a day old:

\begin{abstract}
"When she was born I was told she was a boy, because when you looked at her genitals they didn't look properly formed. And the midwife gave me my baby and said, 'Here's your son, you've had a boy.' I had my baby at about $11 \mathrm{pm}$, and then at about four o'clock in the morning I was woken up by one of the registrars. He came into my room and said, 'Look, there is a bit of a problem, we understand your midwife told you last night when your baby was born that it was a boy. We have actually had a wee look at the genitals which are not formed properly, and at this stage we actually don't know the sex of the child'."
\end{abstract}

(Anonymous 1, 2010, interview).

The mother then recalls her shock when a clinician could not give a definite answer to whether her child was "a boy or a girl". Her comments reinforce my assertion that New Zealand's small population (where numbers of intersex births are smaller) can be problematic for clinicians and hospitals who may have never encountered intersex cases before:

\begin{abstract}
"He said, 'I'm not quite sure, but I have...' - he had printed off a couple of pieces of paper, and he said to me, 'I think what your baby may have is CAH, which is congenital.' And I was sort of like - I was stunned, because I thought 'What's he talking about?', because I just didn't know what he was talking about. He said, 'I don't know much about it myself, but I've gone back and I've photocopied some papers.' So he gave me the papers to look at, and I was just like... what's going on? Because it was four o'clock in the morning, and obviously I was a little bit tired and fatigued, and he said to me, 'At this stage we don't know what the sex of the baby is.' And he said, 'No one knows what to do from here.' So no one sort of knew what to do. We [she and her family] all just sat there like - I was like, ooh! [imitates stunned expression]"
\end{abstract}

(Anonymous 1, 2010, interview).

I ask the mother if any of the hospital staff had informed her about support organisations:

\footnotetext{
${ }^{57}$ See diagram about "hormone conversion" on page 84 .
} 
“All I probably had was my family, and I was just like, 'How's this happening? I don't get what's happening,' and he [clinician] said, 'Oh, it's called congenital adrenal hyperplasia, it's when a child is born like unisex or sort of... two sexes.' And I was just like, 'I don't get this, she told me it was a boy.' And he said, 'Well at this stage we're not quite sure'."

(Anonymous 1, 2010, interview).

While Sarah experienced shock because her son's health was in serious danger, the other mother's (Anonymous 1) shock was because of, I would argue, a lack of information and experience with intersex matters at her hospital. While the health of Anonymous 1's child was not in any danger, her shock, I suggest, was also because her sense of "normality" (paradigm) of "boy or girl" was disrupted (McEwan, 2010, interview). As some clinicians assert, parents are anxious to know if their newborn children are "all right" and become upset if clinicians are hesitant to give a definite answer (Barnes \& Cheetham, 1999, p. 980). Many people are also unaware about intersexuality as it, for example, does not arise in media sources as much as other conditions such as Down syndrome or autism. Anonymous 1's child, who was born on a Tuesday, was then placed in the hospital's special care unit due to "a bit of jaundice" and underwent a blood test:

"Obviously they did the wee little [test] - the stem, the blood, because they said to me it actually might take some time, and it came back on the Friday. One of the doctors came in and he said to me, 'I'm so happy to let you know that [your] wee little baby is a girl'."

(Anonymous 1, 2010, interview).

She again comments on the hospital's lack of experience with intersex cases, and describes the prior period of "uncertainty" and clinicians' advice:

"I think [it was] because the hospital [where her child was born] was inexperienced. They [clinicians] said things to me, like, obviously hold off naming the baby - obviously that makes sense because we didn't know. Then they said things like, 'Oh, I think you should not have any visitors, don't encourage visitors because it might put you in an awkward spot on what to tell them.' I said, 'Well I can't send people away,' and they said, 'Oh we just advise you probably maybe not to have any visitors, just sit here for the week until we figure it out.' It was, yeah... I think that was probably just from a little bit of lack of experience, that they didn't know - 'What do we do?'

"It was a couple of hard days. I think it was more just getting my head around... 'Why has this happened?' I didn't smoke, I didn’t drink, I walked every day, I did exercise, and I was in labour for an hour 10 [minutes] so just everything went really, really well. And I had a really easy labour, I had about four pushes and my baby was out. ... So it was just like a good pregnancy, a good birth and I thought, 'Why has this happened to her? This is not fair.' I think it was just the first couple of days when you go into shock and you're trying to get your head around everything and stuff like that. And she was such a good little baby as well."

(Anonymous 1, 2010, interview). 
The clinicians' advice, that the mother should keep visitors away till the child's sex was confirmed, reinforces the societal view that newborn children can only be male or female and unawareness about "biological varieties" (Diamond \& Sigmundson, 1997, p.1046). The clinicians may have also wanted to prevent the mother becoming upset, should visitors ask questions and hence put the mother in a so-called difficult situation. The situation's "unfairness" as the mother commented, particularly as she kept in good health during her pregnancy, again suggests that her sense of "normality" was disrupted. This, I suggest, resulted when clinicians not only questioned her child's initial sex assignment but undertook tests - which imply that something is wrong. Another mother (Anonymous 2) also describes her thoughts and feelings when her daughter was born. Like Anonymous 1, the mother's comments also suggest that her hospital had little experience with intersex issues:

\begin{abstract}
"When she was born they [clinicians] told me I had a little boy. She presented with ambiguous genitalia. So we were understanding that everything was perfectly fine - very healthy child, there was no obvious - other than the ambiguous genitalia issue. So we gave it a name and sort of got on our way and it wasn't until the next morning that they came in and said, 'Actually no, we need to talk to you. There is something wrong and we think we know what it is but we're not sure, we need to come... do tests.' And that's when they told us. So I guess for me it was, 'How could you make a mistake like that!' I guess as a parent it's sort of like you have males and you have females... I hadn't really come across a lot of intersexed or gender-issued people before. So it was like, 'How could that possibly be that you say to me today I've got a boy and yesterday's a boy - today they're not sure?' And then told that we may have to make that decision ourselves, that was - yeah, we didn't even go there - not to start with anyway."
\end{abstract}

(Anonymous 2, 2010, interview).

When clinicians initially advised the mother she had a son she told "immediate family and the odd friend who was very close" (ibid.), which suggests that she wanted to protect her child from possibly being the subject of gossip by others. The mother recalls that, during this period, "we were all very excited" because of the "good news" that "we had another child" and that "it was all healthy and it was a boy" (ibid.). She describes her feelings about announcing the birth:

\footnotetext{
"And then the next day they [clinicians] came to us and said, 'Well actually no, we're not sure what you've got, have you put it [birth announcement] in the paper?' And so we had to go to the paper and get it withdrawn before it had been published. And then just sort of quickly went round... I don't think we so much went round everybody, we just left it at that stage because it's like, 'Well how do you actually explain to everybody now that we actually don't know what we've got?' Because we don't know and - I think it was that black and white box thing again, so we chose to just wait a little bit until we found out
} 
exactly what was going on. I think it was probably about a week later - maybe 10 days later, when the test came back positively identifying that she was actually in fact a female."

(Anonymous 2, 2010, interview).

The mother's alarm at clinicians "mak[ing] a mistake" about her child's sex assignment again suggests a lack of awareness and experience on the hospital's part about intersex issus. Another mother (Anonymous 1) recalls the colour-coded cards attached to the cot in the hospital during the first few days of her child's life. The cards, which contained details such as the clinician's name and the baby's weight, were coded as blue for boys, pink for girls, and white for "uncertain":

“...our first one was blue, and it just - we didn't have a name then, it was just 'Baby'. Then they took it out and they had a white one in there, and then on the Friday when they told me she was a girl, they all came in fluffing and they put a pink one in there. She still wasn't named by then, so it was just 'Baby of [mother's name]' or something like that.

"I don't actually know if I kept them, I think I may have kept maybe just the pink one. If I kept all of them I would have happily explained to my child all this when she is of an age to understand, when she won't be upset and all the rest of it. If she said to me, 'Well I don't really want to keep the blue one or the white on - throw them away, I'm a girl, I would just like the pink one,' then that's up to her. If she'd like to keep all three, I'm happy for her to have all three as well, as part of her little life journey."

(Anonymous 1, 2010, interview).

These coloured cards, I suggest, can be regarded as an individual's first concrete marks of gender which reinforces Western society's gender (coded) culture: the notions of "blue for boys" and "pink for girls". Indeed, Briffa (in chapter 7) remarked that his female assignment resulted in a pink room (Briffa; in Bragge, 2005). Anonymous 1's comment about hospital staff "fluffing" when her baby was assigned female also resonates with a psychological study titled "Baby X Revisited" (Fausto-Sterling, 1985, p. 137). The study involved two groups of individuals whose responses were observed when playing with a three-month-old baby: one group was told the baby was a girl when in fact the baby was a boy, and the other group was told the baby was a boy (ibid., p. 137). The observers noticed that individual's responses were based on gender stereotypes: individuals who were told the baby was male handed the child a toy football more so than a doll, while an individual from the other group (who believed the child was female) commented that the baby was "friendly" and that "female infants smile more" (ibid., p. 137). 


\title{
Parents' experiences with medical professionals
}

Sarah recalls that visits to mainly an outpatient clinic during the first three years of her son's life were not particularly child- nor family-friendly. She describes the nurse at the clinic as "a very old, matronly-type woman who had no insight into any kind of psychological stuff", "a tough lady" and "an old-style nurse" (Sarah, 2010, interview).

She further recalls that the necessary visits to the clinic, when her son had blood samples taken because of his CAH condition, were "awful" and "very stressful" times:

\begin{abstract}
“...he never had bloods taken well, he had terrible veins. So in the end, rather than having come back with about 10 puncture wounds, we gave permission for them to take it from the jugular. So two people would hold him on the bed - and this is as a baby, and this went on till he was about three - which is far too old. Then someone would stretch his head over the side to make him cry, so his jugular would stand out - and then they'd do a jugular stab. So we would have that done... whenever we needed bloods really.

"That carried on till he was about three, and then somebody decided that that wasn't perhaps so good for him. But he did have terrible veins. So it was a bit of a difficulty. No one talked to us about EMLA, ${ }^{58}$ which is an anaesthetic cream - perhaps it wasn't available then. No one talked to us about other anxiety-reducing things, no one talked about how it was for me - it was just so difficult. And, of course, I would do it all by myself because my husband was working - I just did it really. But looking back, I really could have done with some support."
\end{abstract}

(Sarah, 2010, interview).

Because of the difficulty of taking blood samples, Sarah remembers how her son would become "incredibly distressed" when she took him to the hospital and that, even at the age of six months, her son ("a bright kid") sensed Sarah was taking him there (ibid.). Sarah recalls her experiences dealing with the hierarchical medical culture of the public hospital, and the lack of support when her son became seriously ill:

\begin{abstract}
"Two or three other times in his infancy, up to the age of two where he became unconscious, we rushed him in. Things were not going right, he was hypoglycaemic. It wasn't explained to us that children with that condition can become hypoglycaemic quite easily. The doctor hadn't discussed this with us, and part of our difficulty at the time was that the paediatric department had been run by a series of doctors who were very clever, but were well-known for being quite autocratic and narcissistic. So we got some clever diagnoses, but we had piss all in terms of communication or empathy or support. It literally was non-existent.
\end{abstract}

"I think our difficulties... we had more difficulties interfacing with the medical culture here in [region where Sarah lives] than we did in managing the condition. Aspects of the condition became more problematic because we weren't able to have this communication that we needed. The reality was it was a tough time."

(Sarah, 2010, interview).

\footnotetext{
${ }^{58}$ EMLA cream gets its name as it contains a eutectic mixture of local anaesthetics (Oxford, 2003, p. 224).
} 
Sarah then describes the power relations and hierarchical culture present in the hospital's environment:

\begin{abstract}
"There were some aspects that the doctor did very well. He got onto things - he really did make a big effort, but he had deficiencies of style that came out of that era medicine where the doctor was expert, with a capital E. The doctor at worst was God, and there's still some of that that's still part of the underbelly of medical culture - still in New Zealand. It's not widely acknowledged, and certainly doctors wouldn't admit it. I think mainly because medical people don't see it. You have to have a lot of insight, and an ability to stand outside a culture and yourself in order to analyse that. And that's not easy when you've been trained and brought up with a certain ethos, with doctors who've modelled this stuff.

"I don't wish to be unfair on these doctors - I'm just saying what my reality was, but it could have been a hell of a lot better. And it was better elsewhere in New Zealand, part of it had to do with the personalities of these people. In fact at that time people who were budding doctors, wanting to be paediatricians, were put off doing paediatrics because of the culture at the hospital. It was well known. It was hard.

"So as a client or a parent coming in, I knew I couldn't ask questions. It was very, very difficult to be assertive. I certainly couldn't ask questions of the doctor, and there were things I didn't understand and the things I knew - I had questions about and thought could be done better. But there was no way I could make that happen, I was far too disempowered really."
\end{abstract}

(Sarah, 2010, interview).

Sarah's experiences of this public hospital's hierarchical system echo perspectives of power relations at National Women's Hospital, and when obstetricians and gynaecologists felt threatened by the home birth movement in New Zealand (Kedgley, 1996, p. 244). Sarah's comments about the hospital's hierarchical culture - that junior doctors were "put off" and she felt "disempowered" - suggests that more senior clinicians (at the hierarchy's top) condoned this culture. This hierarchical culture is akin to the "experiment": when McIndoe's concern was disregarded by the Hospital Medical Committee at National Women's because he was a less senior clinician (Jones, 2009, p. 73-74). Sarah's son was also born two years before the Cartwright Report and subsequent establishment of patient advocates at hospitals throughout New Zealand.

Her experiences therefore offer another insight into New Zealand's medical culture prior to patient rights becoming officially recognised.

Sarah remarks that during her son's "early years" she unsurprisingly became depressed, particularly because of the lack of support:

“...nobody, including my GP, stopped to ask, 'How are you? How is it for you?' It [hospital system] was isolated, unsupported, we got given no information at all - except what we hunted down from medical texts. And that was a terrifying experience because the 
medical texts look... they pathologised everything, they want to know when things go wrong. So that's what medical journals are about, the fact that a person doesn't take their pills and their leg falls off or whatever. So it was not good literature to read, and there was nothing else around, there was no support group, there was no literature for the layman. The doctor said to us, on one of our earlier visits, 'There is another family in the area with two girls, but I'm not going to put you in touch with them because I don't think it's the right thing for you, because you're a medical family' - my husband's a GP - 'and you will just find they will ask medical questions, and it will put you in a difficult position'."

(Sarah, 2010, interview).

Sarah's experience during the early years of her son's life emphasise the importance of community/support groups for one's emotional well-being (one of which Sarah founded herself as a result of the lack of support), irrespective of a family having medical knowledge or not. Her comment about the lack of information resources for nonmedical lay people reinforces one of Leigh McCarthy's motives for creating a pamphlet aimed at parents of newborn children (see chapter 12). Indeed, Sarah's comment about the "pathologising" element of medical texts further highlights the importance of easyto-read, assuring information resources such as McCarthy's pamphlet. But aside from a lack of information, the clinician's reluctance about putting Sarah in contact with another family suggests that he may have not wanted to upset Sarah - that she may not be able to cope. Bronwyn, a mother of four adult daughters, similarly recalls her experiences with a paediatrician at a public hospital when their first two daughters were diagnosed with $\mathrm{CAH}$. She remembers that the clinician was not forthcoming with the exact diagnosis of her children's condition because, due to Murray and Bronwyn's young age at the time, he did not consider that they could handle a so-called difficult diagnosis:

\begin{abstract}
"He was very definitely withholding information because - he assumed that because of our age - I was 19 and Murray 21, that we wouldn't be able to cope. We were kids, which we were, we were young. He [clinician] was pretty young too, but a little bit older than we were! [laughs] We were not treated seriously and we were not treated as if we could take on board any knowledge, and we - I think he made a deliberate effort not to tell us. Whereas as soon as we had the words congenital adrenal hyperplasia I was able then to go away and find - and I was reading some information which I had gained when he came into the room, and he saw that I was reading it and he just looked at me - and I just burst into tears.
\end{abstract}

"Now it was really interesting, because his assumption was that I had burst into tears because of the enormity of the information of what I'd read, when in actual fact I burst into tears of relief because, 'Is this all it was?! This thing's treatable - there's no problem, the kid's going to go on drugs so it's treatable. External genitalia - it's going to be fixed up surgically, it's only a wee operation - tiny little operation compared to so much that could have happened.' And it was like, huh [imitates sigh of relief] - why didn't someone tell me it was such a simple thing? So there was that difference in not being taken as being able to cope, when in actual fact I was well able to cope."

(Bronwyn, 2010, interview). 
Bronwyn recalls that, while the paediatrician appeared to be "very arrogant", she and Murray reached a point where they gained his respect: "We got a very good working relationship going. It was no longer a problem after three or four years" (ibid.).

Murray's comments also illustrate a shift in power relations between laypeople and a clinician:

\begin{abstract}
"It took us a wee while to break in with our paediatrician, he treated us perhaps as maybe kids or unknowledgeable, and we were young. But once we won him over he wasn't so bad, Bronwyn just persisted and asked very intelligent questions that she'd researched and everything, and we just kept at him until we produced the goods! [laughs] And we eventually had quite a respect for each other... And a very, very good relationship. But initially he treated us as not knowing anything - 'I'm the doctor here', but we were strong enough and especially Bronwyn."
\end{abstract}

(Murray, 2010, interview).

Murray, who attended specialist appointments with Bronwyn, remarks that the relationship with their paediatrician was "perhaps just his personality and who he was" and considers that he and Bronwyn never "really felt threatened" by him (ibid.). However, he remembers that the paediatrician “certainly didn't treat us as being intelligent" and that he and Bronwyn "wanted to know all the ins and outs, not just half of it - we weren't going to be fobbed off' (ibid.). Murray and Bronwyn's experience with their paediatrician again resonates with Coney's (1988, p. 246) illustration about power relations between clinicians ("experts") and patients (“ordinary folk"). However, a shift in power relations occurred when Murray and Bronwyn persistently asked questions and researched information about $\mathrm{CAH}$. Another shift in power relations occurred when Bronwyn expressed relief instead of distress once she found out the exact name of her children's condition. Aside from power relations, Bronwyn's comment that the clinician was withholding information suggests that he may have felt uncomfortable and awkward when confronted by upset people.

Another mother (Anonymous 1) recalls a more positive experience with her clinician soon after her child was diagnosed as, in contrast to Bronwyn and Murray's experience, her clinician was more forthcoming with detailed information. In contrast with Sarah's experiences with a hierarchical hospital culture, the mother (whose child was born at a different public hospital than Sarah's and Bronwyn's children) recalled that her clinician was approachable, particularly when asking questions: 
"I was really lucky because I think I went into shock. I can't remember the name of the doctor, it's in my child's baby book - he was absolutely wonderful. I think he realised I got into a little bit of shock, and he said to me, 'What I want you to do is when your mum and dad get here, or the extended family, you give me a beep.' He was on rounds, then he got all my family to sit down, and he said, 'Right, this is what's going on, your wee lovely baby has CAH, obviously she's born with it, it's not from any abuse from mum. Mum wasn't drinking or doing drugs, it's got nothing to do with that, it's from two parents who have this cell and it's one in 50,000.

"So I really appreciated that because I think it was hard to explain it, because I didn't know all the proper medical terms and I thought, 'Oh what was that word?', and I kept trying to refer to the notes. It was just handy that someone with his background, who looked after my baby, sat everyone down so that everyone was basically on that same wavelength. And he explained the whole thing: 'From here what will happen is that she will have surgery when she's older, on her genitals to fix them...' I think it was just helpful. I was in the room as well so I could actually just sit there and listen to the sequence of the doctor, so after a while when he wasn't around I could sort of step up and go, 'Yep, this is what my child has'."

(Anonymous 1, 2010, interview).

It is possible that this clinician was more approachable as Anonymous 1's child was born some years after the 1988 Cartwright Inquiry, when patient advocacy in New Zealand would have been established for some time. The mother's comments also suggest that her public hospital was less hierarchical and "narcissistic" (Sarah, 2010, interview) in that, unlike Sarah's hospital, a culture of empathy was prevalent. At the age of "about two or three" the child later underwent genital surgery performed by a clinician who came from Australia to New Zealand (Anonymous 1, 2010, interview), which highlights a lack of specialist clinicians in New Zealand because of its smaller population. The mother recalls her feelings of when "a swarm" of other clinicians observed the clinician performing the four-hour procedure (ibid.). Because of her hospital's (where her child was born at) lack of experience with intersex issues, she wanted the clinicians to observe the surgery in order for them to gain experience and help other parents:

\footnotetext{
“They asked me if I minded, and I said to them, 'I don't look at the doctors as being nosey'. I would like to think that they're coming to get a little bit of experience so the next time a wee little girl comes in they'll think, 'I was here when [clinician] was here and I know a little bit about this - he taught me this, he told me...' It may give them just a little bit of information, and that wee little bit of information is going to grow, and keep growing. It may be just a reassurance or help for the next family, because when we got to the hospital I sort of... [imitates shaking as if very nervous]

"I said to her [paediatric endocrinologist], 'Please don't think I'm offended by a million doctors trying to have a look', they need to see this so next time they meet a mother like me who's absolutely in shock and frantic they'll know that 'we had a wee girl here that had the surgery and it was absolutely everything'."
}

(Anonymous 1, 2010, interview). 
The mother commented that she wanted the surgery to be performed when her child was at a very young age, and that her child "doesn't have much memory" of this as she once asked if she had been in hospital before (ibid.). The mother recalls her feelings soon after her child's surgery:

“...she'd been in there for a week. Because it was a horrendous amount of stitches that she had, but the paediatric endocrinologist came in after the surgery was done and she said to me, 'Compared to what your child had, with no vagina and just a stalk [enlarged clitoris], to what he made, it was absolutely amazing what he [clinician] transformed her into.' It was a full vagina, and all he did with the bit they call a stalk - it sort of stuck out, what they do is a clitoris reduction, they reduce it down, so it was just a normal size. The doctors at the hospital were just like, 'Oh my God'.

"Everything went fine, my child was on morphine for a week - no complications, no blood clots, she had a catheter. After a week we got her to actually physically stand up and walk, she'd been lying on her back for a week. Then I took about two weeks off from work, and I looked after her at home, I gave her salty baths three times a day - she was a wee bit tender but they'd given us morphine to take home. She was absolutely fine, there was no pop stitches, there were no infections - nothing like that, so yeah we were really, really lucky I suppose."

(Anonymous 1, 2010, interview).

The mother was advised about facilities in Melbourne and the possibility of receiving government funding for "one parent" to travel there from New Zealand, or that the surgery could be performed in New Zealand (ibid.). The mother requested the latter in order to help other parents in her region (ibid.). Her wish to help other parents experiencing shock, in the event that their children's sex assignment is questioned by clinicians, again reinforces the lack of awareness about intersexuality in New Zealand. The mother's empathy towards other parents is also similar to Sheryl's (in chapter 9): that children's intersex diagnoses are a stressful time for families (Sheryl, 2010, interview).

Jo, the mother of the intermediate school-aged child with $\mathrm{CAH}$, remembers receiving her child's diagnosis when she was 10 days old: "Consequently, and with the other [health] conditions that relate to $\mathrm{CAH}$, you tend to - I really had to struggle to not wrap my daughter up in cotton wool" (Jo, 2010, interview). While Jo remarks that her daughter's current endocrinologist is "wonderful", like Bronwyn and Murray, a shift in power relations occurred between Jo and other clinicians because of her extensive research about $\mathrm{CAH}$ : 
"Almost every single one I've seen... they're very non-threatening, but I have been dealing with them since my daughter was a baby. Also because they don't patronise me because I know a lot about it and I've done a lot of study and research into it myself, so that is one of the big things. They're fantastic with my daughter and they talk about their own kids and their own experiences... They just are really, really good. I mean, I can phone our endocrinologist at any time if I want to ask anything."

(Jo, 2010, interview).

Jo recalls dealing with another clinician whom she considered to be "quite patronising" and that her child "didn't like him":

“I just said, 'I'm not seeing him anymore, if you put him in I won't see him.' So it's as simple as that. And I've heard wonderful reports about him from other people, but it's how comfortable my daughter is. Especially when she was coming into that 10-year-old age group, and she wasn't comfortable with him. And if he's got to physically examine her she's got to be comfy."

(Jo, 2010, interview).

Jo's advice to parents of intersex children dealing with clinicians is akin to Jill

Rakusen's feminist argument of questioning and doubting medical institutions

(Rakusen, 1981, p. 97):

"I wouldn't tell anybody to take everything the doctors say as being truth. One of my daughter's endocrinologists suggested that at the age of 15 she have an adrenalectomy. I said, 'Well why would I do that?' - 'Oh because then you know what her meds are.' I said, 'Why would I put her through an operation to remove her adrenal glands when we think she is actually producing some hydrocortisone - just because it would make my life easier? It's not about making my life easier, it's about making her life better.' So yeah, don't take everything the doctors say as being a good reason. Ask questions of the doctors, always question them - even if they're making some recommendation ask them why."

(Jo, 2010, interview).

Like Sarah, Jo similarly recalls a negative experience when her endocrinologist, then a registrar, had difficulty obtaining a blood sample from her child:

"Another thing - because for the first year, every month, you're in hospital doing blood tests, don't put someone in there who doesn't know how to get the blood. Our endocrinologist was a registrar at the time and he remembers me telling him to - very impolitely - leave the room. Because he'd been in the backs of both her hands, both the crooks of her elbow - I'm holding her down, he can't get a blood. And I just told him to leave the room [laughs]... [becomes serious] I told him to fuck off, and get out, and leave my daughter alone, and don't come back until there's someone who can do it. Have somebody who can take these bloods off these kids, it's not a learning process. If they want to learn they can learn on me, not on my child. And that was incredibly distressing for me, and incredibly distressing for my daughter, and I'm sure incredibly distressing for our endocrinologist when I told him to go away."

(Jo, 2010, interview). 
Jo also recalls being "sent out" the first time her child was having a blood sample taken.

She nevertheless stood up to clinicians when her child was obviously distressed:

\begin{abstract}
"I remember standing outside when my husband was back at sea [in the navy] and I could hear my daughter screaming. And I said to them, 'That's it, you are never sending me out of the room again, I would rather be in here and do this' - they should give you the option. Some parents might not want to be there, they might not want to hold their baby down, but that option should be given to them."
\end{abstract}

(Jo, 2010, interview).

Like Mitchell and other intersex people (in chapter 7), who remark that medical institutions find intersex people "fascinating" (Mitchell; in Keir, 2002), Jo remarks that while clinicians may regard children with $\mathrm{CAH}$ as interesting cases they should remember that they are not medical subjects:

“...that's something they seem to forget. Yes, these are little patients and the conditions are reasonably rare enough to be very interesting, but they've got to remember that they are our babies - above all and end all. These are our babies, these are absolutely everything we're living for. So they need to make sure they treat us with the respect when we're in the room."

(Jo, 2010, interview).

In comparison with clinicians, Jo remarks that she has never had negative experiences with nurses: "It was never the nurses - I haven't come across a nurse yet whom I haven't adored" (ibid.). Another mother (Anonymous 2) also recalls negative experiences with clinicians when they attempted to obtain blood samples from her daughter. Like Sarah, the mother remembers a hierarchical, "expert" element amongst some clinicians:

\begin{abstract}
"In the very early stages when she was first diagnosed we had lots of blood tests that needed to be done. And I guess to some extent we felt undervalued a little bit, because there were certain docs in there who - I guess the scenario is: 'We know what we're doing, so just let us get on with the job.' And I'd say, 'Well hang on a minute, my daughter's screaming her head off, I need to comfort her, we need to be able to make sure that she's in an environment where she's not going to be threatened or feeling threatened, because this is lifelong - it's not just a quick fix.' And so there was the odd time when we did feel undervalued as parents, and so I think that's probably when I started making some decisions about: 'Actually, no, she's our daughter and you will do as we say.' You know, 'Let's work together, alongside each other, not against each other'."
\end{abstract}

(Anonymous 2, 2010, interview).

The mother recalls that the greatest influence on her making these decisions was her Plunket nurse: 
"I remember her visiting me not long after I'd brought her [daughter] home, and they'd had a go at getting some blood out of her and they'd had like seven attempts, and she just came in and said, 'That is totally unacceptable. You go in there and tell them they get two tries, and if they don't get it you'll come back tomorrow.' And it was like, 'Wow, can I do that?', and she said, 'Yes you can.' And that was when I suddenly realised 'Actually yes, I can do that'. Each person is quite different in terms of how they deal with things, and it was just good to know that if I wasn't comfortable with something then I was going to ask that question, and that's where we went from there."

(Anonymous 2, 2010, interview).

Though her Plunket nurse had "no prior knowledge of CAH", the mother further recalls that she was very supportive and empathetic:

"Oh totally, she was totally the one who gave me the encouragement - the thing to say:

'Hey, I don't understand this - talk to me about it. I'm not a stupid person, so talk to me so that I can understand so that we can do this together'. ...

"I believe that she was trying to encourage me to take a bit of control - because this was my child, it was nobody else's ... and we will look after it the best way we can, and if that means that you will only get two shots of taking blood from her and we can come back tomorrow, then that's how it's going to be - rather than them [clinicians] dictating to us. In doing that it empowered me then to go into the hospital and say, 'Hey actually I want to work with youse [sic], and so this is how I think we can do it.' I think we got a really good rapport going after that because people started to understand."

(Anonymous 2, 2010, interview).

The mother recalls another unpleasant time when clinicians tried to obtain a blood sample from her child's groin because of the difficulty in obtaining it from her arm. Like Jo, a clinician "ordered" the mother to leave - which she refused to:

“...he told me to get out - he literally ordered me out of the room. So when they'd finished
doing it and he walked out, and I just said to him, 'I don't ever want to see you anywhere
near my child again. I don't care who you are, but you don't tell me to do that.' I said, 'Did
you get the blood?' - 'Yeah.' 'That's it. I don't want you anywhere near her again.' And
that's the sort of power that the Plunket nurse gave me because I felt confident enough that I
could do that. He was trying to tell me something that he had no idea how I felt or anything
else, but I wanted to be in there with my child, I should have been left to be in there with the
child. But after that we didn't actually have any more dealings with that particular person [a
clinician]."

(Anonymous 2, 2010, interview).

Like Anonymous 2, Bronwyn comments that while her Plunket nurse was intrigued by her child's condition she was "very open and supportive" (Bronwyn, 2010, interview). A midwife who ran a local playgroup was also particularly helpful, and Bronwyn felt comfortable discussing medical matters with her:

"She helped me in practical ways to 'face' the other young mothers - that is, being aware that nappy-changing needed to be done away from the [Plunket] group, as I didn't feel comfortable having curious eyes looking on - if something is seen, it imprints on the brain, 
and I wanted to protect our daughters from that. During hospital visits the nursing staff were consistently open, supportive, respectful and understanding."

(Bronwyn, 2010, interview).

Bronwyn's comment that she wanted to protect her daughter from "curious eyes" again suggests an undercurrent of judgemental behaviour amongst some parts of New Zealand society, particularly small town attitudes towards difference. Indeed, Bronwyn and her husband Murray live in an isolated rural area of New Zealand where connectedness “everybody knows everybody" (ibid.) - is particularly strong.

With the exception of Sarah who encountered a "tough", old school-type nurse, parents" experiences with nurses compared to clinicians reflect a difference in power relations in that while most nurses are willing to work with parents, some clinicians wanted to maintain their position of "expert". This reflects Sheryl's comments in the previous chapter about she and her nursing colleagues discuss matters "in very plain English" instead of "medical jargon" and not "talking down at families" from a high pedestal (Sheryl, 2010, interview). Parents' experiences with nurses, particularly nurses who encouraged and empowered parents to stand up to clinicians, further resonate with the women's health movement during feminism's second wave, which avoided hierarchical structures and followed the principle of "sharing" instead of keeping medical knowledge “mystical" and out of laypeople's reach (Fee, 1978, pp. 287-288). The "knowledge is power" (ibid., p. 286) feminist argument is also reflected by Bronwyn and Jo who made a deliberate effort to undertake research about their children's condition. Consequently, a shift in power relations occurred when Bronwyn and her husband Murray gained their paediatrician's respect, and when clinicians did not, as Jo said, patronise her.

\section{Conclusions}

While I only managed to interview parents whose children had CAH and no other intersex conditions, this chapter highlights the significance of blood tests. These parents' experiences highlight the need for clinicians (1) to not only learn how to obtain blood samples well - particularly on babies with "terrible veins" as Sarah remarked but (2) to exercise sensitivity towards parents, particularly encouraging them to be with their children supporting and comforting them while blood samples are being taken. These two factors would have certainly reduced much stress for Sarah especially who, 
unlike the mother of the now-young adult daughter, did not have the support and empowerment of a Plunket nurse. Jo's assertiveness and lack of intimidation by authority figures was also evident when she told a clinician to "very impolitely" leave her daughter alone (Jo, 2010, interview).

My findings also suggest that there is an acute lack of knowledge about intersexuality at some New Zealand hospitals, with regard to parents' feelings of shock and stress about their children's conditions. I would argue that information resources about intersexuality and gender diversity (such as Leigh McCarthy's pamphlet in chapter 12) can alleviate shock when a child's initial sex assignment is questioned, particularly information resources that are sensitive, easy to read and understand. Furthermore, empathetic nurses such as Sheryl (in chapter 9), simply sitting with a family, can also alleviate their stress. Sarah's comment about the "pathologising" nature of medical texts resonates with Anonymous 1's alarm ("what's going on?") of when a clinician gave her some photocopied papers, which suggests that they were copies of medical texts. The language in these possible medical texts, I suggest, may have made her child's condition appear more serious and complex. Education, and easily available information resources, would also enable parents to be better informed about choice, which is discussed in chapter 12. However, the issue about genital surgeries becomes more complex in the next chapter, as the intersex people I interviewed held very differing opinions about this matter compared to those in chapter 7. 


\section{Chapter 11: \\ People's experiences and understandings about surgery and gender}

Like the New Zealand Human Rights Commission's report (in chapter 7), which contained differing opinions from intersex people about gender identity (HRC, 2007, pp. 80-81), my findings reveal differing understandings about gender from the five intersex people I interviewed. Three people firmly identify as female, whereas two people stated that their gender identities were neither male nor female.

This chapter begins with four people's experiences with surgery (Mani Mitchell's experiences and views are outlined in chapters 7 and 9). A finding from my interviews was that three people's narratives about surgery differed from those already in the public domain (in chapter 7). Two prominent issues emerge throughout this chapter: silence, which New Zealand's connectedness can ensure - particularly in small rural towns, and support, which is highlighted by some participants' narratives about peers. Another issue is New Zealand's small population which is explained in two participant's narratives. This is with regard to the availability of specialised surgical procedures and, reinforcing Hofman's and Beasley's comments (in chapter 9), the need for a greater team (hence multi-disciplinary) approach.

\section{Experiences with surgery}

Lisa, a 29-year-old woman with CAH, was initially assigned male by clinicians who "swore" that she was "a perfect little boy" (Lisa, 2010, interview). Three weeks later a test revealed her chromosome type to be female (46,XX) (ibid.). Lisa considers that she may have been one of the first babies in her region to ever undergo an ultrasound examination to determine sex organs such as ovaries (ibid.). She remarks that the current heel prick (blood) test for CAH is "a lot better for the parents because they're going to find out a lot earlier" (ibid.) about their child's chromosome type. Lisa is unsure how old she was when she first learnt she had CAH:

“I don't really know. Obviously I've always had it... because I've always been taking the tablets, so I guess I've always known. Mum and Dad would have just told me little bits as I 
grew up. I've always known that I had it, because - tablets twice a day or three times a day, you can't hide from that."

(Lisa, 2010, interview).

Lisa cannot remember her parents telling her until she was aged about nine or 10 when she began visiting a hospital two or three times a year (ibid.). She then remembers being "in and out of hospital a lot" to undergo blood tests and visit specialist clinicians to check that she was "healthy" (ibid.). Surgery was performed on Lisa's ambiguous genitalia when she was "very, very young" which, she said, may have occurred during her first year but is "not entirely too sure" (ibid.). She then underwent two "corrective" surgical procedures to "tidy things up" at the ages of 11 and 13 which were performed in New Zealand ${ }^{59}$ and at Royal Children's Hospital in Melbourne respectively (ibid.). Lisa also "thinks" that "a couple" of other surgeries were performed during her early years, but is unable to confirm whether she underwent these or not:

"I can't remember about any of the very early ones - I think I had a couple. I'm not too sure actually, it's just something which is sort of in the past and you keep it in the past."

(Lisa, 2010, interview).

Lisa does, however, recall that she was informed about her "corrective" surgeries:

"I understood and why... Personally I wanted things sorted out myself, so there was an element of my side in it and then there was also the practical side as well - practical, silly things like peeing... At the time, when you're 11 or something like that, you want to pee reasonably confined! [laughs] That sounds weird but for me at the time that was very important."

(Lisa, 2010, interview).

She has difficulty remembering her experiences of hospital stays in New Zealand, but can remember her experience in Melbourne which, she says, was "certainly better" than in New Zealand:

“...it was really good, they were very, very supportive. And we stayed in the Ronald McDonald House, Mum and Dad stayed at it while I was having the surgery, and then afterwards as a family we stayed over there and had a holiday, a bit beforehand and a bit afterwards. After I'd recovered we had a bit of a holiday, we had an aunty over there as well and we went and saw her and stuff."

(Lisa, 2010, interview).

\footnotetext{
${ }^{59}$ In order to ensure confidentiality I have withheld the exact location of this hospital.
} 
Lisa comments on her experience in Australia compared to New Zealand, and that the former was better:

\begin{abstract}
"Well we got to go overseas! [laughs] It was our first big holiday - well first overseas holiday, and just knowing that we had the best surgeon at the time in Australia..."

[I ask Lisa who the surgeon was]

"I can't remember... but he was the best one in Australia at the time, so that was always a good vote of confidence, whereas the one we ended up with in New Zealand we knew wasn't the best one in New Zealand at the time as well. So for me, knowing that sort of support, and things like Ronald McDonald House just made the whole thing just so much easier."
\end{abstract}

(Christmas \& Lisa, 2010, interview).

Lisa cannot remember the "finer details" of her stay at Royal Children's:

“...it's sort of something - I went and did it, I left... I know I wasn't in hospital for very long. I think it was an overnight and then I was out the next day sort of thing, or it might have been two nights... it might have been longer, but I probably have just shut it out, the rest of the holiday was the important thing when I was in Australia. It wasn't the hospital which was the important thing for me - even though it was, it wasn't. It wasn't my priority at that age."

(Lisa, 2010, interview).

Lisa's comments that she "keep[s] in the past" possible early surgeries and that she "shut out" recollections of her stay at Royal Children's Hospital suggest that her experiences with surgery may have been unpleasant or embarrassing. This is in contrast to when she readily acknowledges more positive aspects in Melbourne such as supportive staff and Ronald McDonald House. In comparison, the hospital in New Zealand being a women's hospital possibly may not have been child-friendly: she may have felt isolated, which echoes Graham's (2006) experience (in chapter 7) of being “the only child alone on the ward". From Portelli's (1991, p. 53) perspective, Lisa's comment about "keep[ing] it in the past" (Lisa, 2010, interview) suggests that she is hiding (or blocking out) information about events which may be traumatic - hence Lisa may not have wished to revisit them. Lisa's comment that she "personally wanted" (ibid.) the corrective surgeries, particularly during early adolescence, is an indication of not wanting to stand out or feel different amongst peers.

Jacqui, Lisa's 32-year-old sister who also has CAH, says that her son (aged seven months at the time of our interview, who does not have $\mathrm{CAH}$ ) was delivered via caesarean section because of her previous genital surgeries: "We weren't going to go 
back and undo a lot of hard work [vaginal surgery] that some very amazing surgeons [in Australia] have done" (Jacqui, 2010, interview). Jacqui is unsure how many surgeries she has had, but thinks the number is five (ibid.). She thinks that the first four surgeries were performed at the ages of seven months, "about two or three", five, and 16 or 17 (ibid.). She thinks she may have had another procedure performed in New Zealand when she was aged about nine, but has difficulty remembering this: "Block it out really, in a lot of ways" (ibid.). Jacqui remarks that, while she has "nothing against" clinicians in New Zealand, New Zealand's smaller population - and smaller number of CAH individuals - can be problematic for the establishment of specialised surgical procedures:

“...and that's why I think it's so important to keep those communication lines open with Australia - especially for us CAH girls.”

(Jacqui, 2010, interview).

Sonia Grover, a gynaecological surgeon, performed Jacqui's latest surgery in 2007 at Royal Mercy Hospital in Melbourne:

“...it's just so, so worth it. I mean, had I not had that surgery I couldn't have had my son ... I'm afraid the sex life didn't exist before then, and I'd let it go that long. Just very, very lucky to have the most understanding husband in the world, who - we were engaged for six or seven years before that, and we've basically a nil sex life so how many guys put up with that! So yeah I was very, very lucky with that. And then we went over and we got it sorted, and it was very successful."

(Jacqui, 2010, interview).

Jacqui has been very particular about taking her CAH-related medication which she believes assisted her in conceiving her son naturally on, she thinks, the "second or third month trying" (ibid.). The surgery that Jacqui underwent at the age of 16 or 17, at Royal Children's Hospital in Melbourne, was "horrible" as it "didn't quite give the results we wanted":

"It was probably too early, as far as - what we [clinicians] were trying to do with the surgery is open things [vagina] up enough so I could lead a sex life, and at that stage I wasn't ready for a sex life. So things just closed back up again, and I wasn't disciplined enough along with a lot of problem girls to use the dilators and things all that time. So yes it may have been successful, but very hard to know. ... Not the greatest thing to go through when you're about that age."

(Jacqui, 2010, interview). 
Jacqui's comment about "problem girls" suggests that teenagers may find it very embarrassing being issued with dilators, and may feel even more embarrassed to seek advice on how to use them correctly. While Sarah, the director of a support organisation, advised (in chapter 9) that girls should reach an age when they feel "comfortable" with using dilators (Sarah, 2010, interview), she comments that difficulties can still occur with older girls who have undergone vaginal surgery:

\begin{abstract}
"So say they have top-up [genital] surgery as an adolescent and say they get a set of dilators, which you have to order specially and, you know, it's all embarrassing for a teenager. And you get these things - you've still got to use them. So this girl I'm thinking of, who would have been in her late teens, had a set of dilators... And she couldn't use them, but she could find no one to teach her how to use them because she lived in the wops. ${ }^{60}$ She was trying to insert them, and she was actually inserting them into the urogenital sinus rather than the vagina, because everything's reconfigured inside. So she was getting excruciating pain using these dilators, couldn't make them work, couldn't find anyone to talk to her about it. She's not in Melbourne [where surgery was performed] - like, she's a million miles away from Melbourne, there's nobody there for follow-up.
\end{abstract}

"So you can see that even if they might go over to Melbourne and have excellent care, then gaps occur because we don't get follow-up care. And that occurs because... you might need counselling and there aren't people. ...that's one of the functions of our [support] group... that at least they can ring and say, 'Hey this is happening, what do you think?' I'll say, 'It's tricky, I don't have an answer, and what I'm wondering about is can you build up a relationship with a GP... gently build up a relationship with someone who could help you with this?' That's what this girl did, and it worked."

(Sarah, 2010, interview).

Both Sarah's and Jacqui's comments about vaginal dilation suggest that medical facilities in New Zealand, because of its small population, have less experience with intersex issues than Australia - which had implications for one teenage girl. However, thanks to Sarah's support group which has first hand experience of intersex issues, the girl managed to overcome silence and embarrassment when Sarah advised her to talk to her GP.

Jacqui's first two surgeries were performed at a public hospital in New Zealand. She wishes that she had visited "more of a specialist" in Melbourne, as she believes these surgeries in New Zealand were performed at a time when medical thinking was about "we can do anything" and "we can give this a shot" (Jacqui, 2010, interview). While Jacqui states that the clinicians "should have kept their hands out in some ways", she

\footnotetext{
${ }^{60}$ Wop-wops, or wops (NZ slang): an isolated or remote area, especially a rural area far away from a town or city.
} 
offers a differing view about performing surgeries early - that waiting till adolescence creates more difficulties:

\begin{abstract}
"I have absolutely no problem with the surgery being done at that age by somebody who's experienced. And in some ways with the CAH side of things where it's to me very clearly defined - 'what you are'-type of thing, I have no problem with it being done early, and I know there's a huge amount of discussion happening around that at the moment - 'Oh should they leave it until the teenage years or not?' It's really hard when you're in your teenage years to go through that - if it's been dealt with it's been dealt with, and they're getting better and better at dealing with it."
\end{abstract}

(Jacqui, 2010, interview).

Like Sheryl (in chapter 9), Jacqui agrees with genital surgeries being performed at an early age:

\begin{abstract}
“The microsurgery side - they're getting better, and they're also getting better - well when you're young you haven't got the same psychological issues that come up - too young to remember, too young to really know. And you get older and you don't - you can't remember it. I don't think it damages you. But when you're in your teens and you're having to go [through] that, you're incredibly self-aware. You're very aware of peers, you're aware of this, you're heading off to hospital for a reason, and how do you tell any of your friends you have to go to hospital for 'what?', 'oh I'm not going to tell you that' - very hard. So I think the bulk of it needs to be done before five - before school."
\end{abstract}

(Jacqui, 2010, interview).

Jacqui's opinion about genital surgery being performed at an early age contrasts with others (in chapter 7), such as seMbessikwini (SFHRC, 2004) who "wants [her] own natural body back" and Holmes who talks about "stolen physical potential" (Holmes, 1998, p 221). While Holmes asserts that she should have had the "freedom" of gender and physical fluidity during childhood (ibid., p. 225), Jacqui's wish that her surgeries had occurred earlier suggests that she wanted a sense of normality, particularly during adolescence when she was "very aware of peers" (Jacqui, 2010, interview). This further suggests that Jacqui was afraid of being stigmatised by her peers (gossiped about, for example). Indeed, while Holmes embraces "queer and intersex culture" (Holmes, 1998, p. 221) and asserts that her "phalloclit" (ibid., p. 225) should have been left alone, Jacqui gives a differing view:

"I'd go without it [surgery] - no I mean it would have been nice not to have had it, be nice to have been alright from the start."

"So when you say alright from the start..."

"Well as in everything - yeah just 'typical female' would have been nice, without having to go through the corrective stuff."

(Christmas \& Jacqui, 2010, interview). 
Lisa's and Jacqui's (2010, interview) comments about shutting out and keeping previous hospital experiences in the past respectively suggest that they may have been unpleasant or painful memories which, using Portelli's (1991, p. 53) perspective, they may wish to keep hidden. Lisa and Jacqui may have also wished to protect their family (a wider group) who may have had negative experiences, as their mother encountered judgemental behaviour from other mothers at a local Plunket group:

\footnotetext{
"I know my mum really, really, really struggled, and what she thought were good friends ended up being... [hesitates]"

"Not so good friends."

"Exactly, yep. So yes I know my mum had big problems there. I'm now at peace with... the condition I've got, and I speak pretty openly about it, so I don't have too many issues."
}

(Christmas \& Jacqui, 2010, interview).

While the surgery at the age of 16 or 17 did not give the result that she wanted, Jacqui says that her hospital experiences in Australia were "very positive". She remarks that the staff at Royal Children's Hospital are "excellent" and that she and her family stayed at Ronald McDonald House which was also "excellent, really, really good because we were just right across the road from the hospital" (Jacqui, 2010, interview). Jacqui organised her latest surgery herself with assistance from her endocrinologist who provided a "push-in" (ibid.) for Jacqui to undergo the surgery. Jacqui describes her endocrinologist as an "awesome lady":

\footnotetext{
“...it's just nice with the same person who gets to know you and you build up a rapport. She works via e-mail really well, and that is worth so much. And a phone call - she doesn't mind... she said, 'Look I'm cheap on the phone or on e-mail,' she said, 'I cost to see you.' [Jacqui's endocrinologist practices privately]

No, she's been really, really good for the CAH community here, and others as well. Just overall, her rapport with the public is great."
}

(Jacqui, 2010, interview).

Unlike her earlier surgeries Jacqui's hospital experience with her caesarean delivery, also at a public hospital in New Zealand, was very positive as the staff were "absolutely awesome" (ibid.). Jacqui's midwife, who had previously encountered a mother who had given birth to a baby with $\mathrm{CAH}$, advised that while $\mathrm{CAH}$ matters would "be controlled by [Jacqui's] endocrinologist" she would work with "the baby side of things" (ibid.). Though Jacqui was in a public hospital, her caesarean section was performed by an obstetrician based at a private hospital: 
“...so it wasn't done by whoever on the ward, and very, very happy with that. ...I had already met the surgeon, worked with him, worked through - they knew what was coming, and I wasn't going to end up with whoever happened to be on roster. It all worked very, very well. ... It was private, so yeah I paid for that. But again it was easier as I say doing that. And the other thing is I was a high risk - it was a high risk C-section, first thing in the morning, bang in, done, sweet as - which is really nice knowing [that] as well."

(Jacqui, 2010, interview).

I asked Jacqui what she would recommend for health and support services in New Zealand, for people with variations of sexual anatomy:

"There needs to be more - I think this is the right word, psychological support. ... They're excellent in dealing with the physical stuff, they are not that great with dealing with the emotional side of things. Now over in Melbourne I was offered that extra support if I wanted it, and I was staunch in whatever enough then - I said, 'I'm fine, I don't need that.' ... There needs to be open information for parents of kids, and that's becoming more and more, especially with the CAH support group..."

(Jacqui, 2010, interview).

Jacqui believes that support is particularly important during the teenage years:

\begin{abstract}
"Yes, yes, and around the major events - you know, like the surgeries and things. I've suffered from depression on and off for a number of years, and I think that's probably because of that. I'm free of it again at the moment and hopefully it will remain, but that probably started to become an issue when I - it might have been when I was little, still at home. But when I left home... I had the most awesome parents who were very, very supportive, but I think there needs to be that - maybe counselling available, easy to get hold of, and not to dump you in a - as a psych case basically...”
\end{abstract}

(Jacqui, 2010, interview).

A young adult woman with CAH (Anonymous 3), who hopes to have "no more" surgical procedures, underwent her first procedure at a hospital in New Zealand when she was 18 months old. A second procedure was performed at Royal Children's Hospital in Melbourne when she was aged 11, and an adrenalectomy was performed in New Zealand when she was 19. The point in time when the woman became involved in the decision-making process was when she had her second surgery in Melbourne at the age of 11 when this was her decision:

"I [had] only just been involved, just before the one when I went over to Australia. I was just involved then because it was my decision to have the operation, and we'd talked to a doctor up north and he was very confident that it would be OK, and he was very comprehensive and I could understand what he was trying to say very well. So that was a good thing there."

(Anonymous 3, 2010, interview). 
Anonymous 3 remarks that her hospital experience in Australia was better than in New Zealand, particularly on communication aspects. She says that communication in New Zealand is “shocking” and that, resembling Hofman's and Beasley's proposal (in chapter 9), a greater "team effort" needs to occur "all round":

"Over in Australia they [hospital staff] were absolutely marvellous, I can't think of anything they could do better."

(Anonymous 3, 2010, interview).

I ask Anonymous 3 to tell me about her interactions with nurses in Australia:

"Awesome. They were very cheerful, very polite and they asked you if you were OK... it was amazing over there."

(Anonymous 3, 2010, interview).

Anonymous 3's adrenalectomy procedure resulted in her CAH-related medication reducing from a high dosage which, she said, "was suppressing my adrenal glands to now maintaining it" (ibid.). Both her adrenal glands were removed laparoscopically by two surgeons. Despite communication difficulties amongst some clinicians in New Zealand, the woman describes her paediatrician (whom she visited till she was 18 years old) as "absolutely marvellous":

"He's always cheerful and he always asks you if you have anything to add to what he's said, and he puts it in your words as well so that we can understand what he's saying. He sits down and actually makes the effort to help me understand what's going on with myself."

(Anonymous 3, 2010, interview).

On reaching adulthood Anonymous 3 transferred to an adult endocrinologist who, she says, "seems pretty onto it as well, and he does explain it very well so I'm quite pleased with the transfer" (ibid.). In terms of support, as well as her family the woman has a friend in a different part of New Zealand who also has CAH: "We've pretty much been best friends ever since we found out we have the same condition" (ibid.). She is unsure how old she was when she met this other girl but remarks that they have been friends for “so long":

"I think we got in contact through our parents who ended up being friends, and then as we grew older and understood more we became good friends and helped each other out with questions."

(Anonymous 3, 2010, interview). 
The woman and her friend underwent surgery together in Melbourne, and were even in rooms next to each other which, she said, made the experience easier and more supportive (ibid.). I ask her about advice or support that she considers should be available for parents and their children:

\begin{abstract}
"I think the parents should trust their child's instincts. If the child says that they want to be something else [different gender] then they obviously need the support to get there, otherwise it's just going to be a big battle and there's really no need for a big battle. It's not as bad as people say it is, it's the way people I guess comprehend the meaning of it. If they actually understood and had the information then maybe they'd be more supportive."
\end{abstract}

(Anonymous 3, 2010, interview).

Anonymous 3's comments suggest that her overall experiences of surgery were the most positive compared to other people I interviewed, and intersex people's published accounts (in chapter 7). While she was too young to remember her first surgery she was happy with her female assignment, which is discussed in the next section. Her third surgery was also positive in that it benefitted her health as it reduced her CAH-related medication which was suppressing her adrenal glands. Support was another contributing factor, particularly in the form of a close friend (a peer) with the same condition to share experiences with, which reinforces Diamond's and Sigmundson's (1997, pp 1046-1048) advice that such contact can be an "uplifting experience". Like Lisa's surgeries at the ages of 11 and 13, the woman wanted her second surgery to occur. However, while Lisa prefers to keep details of her experience at Royal Children's Hospital in the past (Lisa, 2010, interview), the woman gives the hospital a glowing testimony. Anonymous 3 was also the youngest of the five intersex participants I interviewed, who underwent her second surgery during the early 2000s, and this suggests that hospital environments may have improved since Lisa underwent her surgeries during the early 1990s.

I also suggest that having a peer and friend with $\mathrm{CAH}$ - especially in a room right next door - added to the woman's positive experience at Royal Children's. Had Lisa and Jacqui had a CAH "buddy" to share experiences with and even visit them in hospital, this, I suggest, may have alleviated any unpleasantness or embarrassment during their adolescent years. Someone outside an intersex person's family may also be particularly helpful as, Jacqui said, some parents may "struggle" with their children's condition 
(Jacqui, 2010, interview). Indeed, having other CAH peers to talk to may have alleviated feelings of self-consciousness that Jacqui felt during her teens.

Rogena's experiences of hir surgeries for hypospadias, at the ages of four and 15, were less positive:

"Well, at the age of four I'm not aware of anything. The only thing I was aware of is Mum brought a big teddy bear in for me, and that's about all I'm aware of. I remember eating ice cream and jelly, I didn't know why at that stage - nothing more. At 15 I had to go back for another operation because the scar tissue had come across, which I think has probably happened again - but I'm not doing it again. Again I did not know - all I was told was that there was scar tissue from my original operation, I was not told anything else. The pain was [pauses]... unbelievable, and that's why I would never do it again.”

(Rogena, 2011, interview).

S/he remarks that the second surgery at 15 "hasn't cured anything":

“...I had no idea what it was all about, and I still didn't until I was almost 40, and I got access to the university library database and could do some research on my own to find out what hypospadias really is. But in the meantime I've had a life - I can't stand up and pee which they [clinicians] say it's [surgery] all to do, I always have to sit down anyway. So what was the point of these two operations with all the pain when I still can't do what they say I'm meant to do."

(Rogena, 2011, interview).

Rogena says she cannot elaborate more on hir experiences of hospitals, clinicians and nurses "because that was just so long ago" (ibid.). Hir only memory is "just waking up with pain" and that, despite being administered morphine, s/he was unable to eat because s/he constantly vomited (ibid.). Rogena suspects that the surgeries caused current problems with hir fertility that, s/he believes, may have been "better" had s/he not been operated on:

“...at the moment it's [fertility] pretty minimal - not non-existent but pretty minimal. Possibly without surgery I might have had a better thing [penis] because there's less scar tissue, less problems... The results I've seen is even people with hypospadias conditions, that have never been corrected, can still fertilise. So therefore what is the purpose of the operation?

“...when I went to a urologist when I was trying to understand myself and my fertility issues, when I asked him about intersex and transgender issues he said - his comment to me directly out of his mouth was, 'These are all dealt with at birth.' And this was only about four years ago. And I couldn't go to anyone more than a urologist - this was not a GP, this was a urologist which I supposed [sic] was meant to be the top person who could help me."

(Rogena, 2011, interview). 
Rogena's questioning about the rationale of surgery to "correct" hir genital variation counter Paré's rationale for a "chirurgical cure" five centuries earlier about not being able to pass urine "a straight line" and "beget children" (Paré, 1649, p. 419) because, as artificial insemination did not exist during Paré's time, a hypospadiac penis could not "cast [spermatozoa] directly into the womb". Thanks to the development of reproductive technology, as Rogena remarks, people with hypsospadias can potentially fertilise. Medical rationale to surgically correct hypospadias also suggests that it is modelled on the "hegemonic white male" (Caslin, 2012) of Western culture who stands up to urinate - unlike men in India or the Middle East who, like women, squat to urinate. The key factor for Rogena's less positive experience was much pain and possible reduced fertility, especially as the surgeries did not give the expected result of being able to urinate standing up. While some clinicians may be concerned about a boy's self-esteem in terms of peers, Rogena remarked (in chapter 9) that standing up or sitting down to urinate is of little importance to hir.

Though Rogena's and other intersex people's perspectives (in chapter 7) have informed my thinking on whether surgical procedures are necessary, Natalie, a transgender woman, gives a different viewpoint from her work as a counsellor. Her comments resonate with feminist poststructuralist arguments about power (Davies \& Gannon, 2005, p. 318), particularly with regard to the consequences of moving beyond social norms. Natalie's views about realities also differ from academic perspectives about “biology-as-destiny” (Butler, 1990, pp. 10-11):

\footnotetext{
"Socially it [biology] affects destiny. It certainly affects the way that you are seen and the way that you perceive society around you, and so that can affect a person in their mental health. So clinically any health professional... as opposed to a surgeon or a general physician [which] would include mental health professionals; so psychologists, psychiatrists, psychotherapists, counsellors... Instead of looking at the medical model and everything around genitals and surgery... they really need to concentrate initially on what is right for this person in their life to be able to help them live their life to the full.
}

\footnotetext{
"Where somebody is not presenting in a way that is socially constructed - the social norms, it then puts pressure upon them because we're social animals. And to be able to fit in socially we need to be able to be seen as within part of a group, and socially that grouping tends to be male or female. ...if you don't follow the norms, you're more likely to be excluded and it is the exclusion from the norm, the exclusion from that grouping, that affects the ability of somebody to deal with things that are going on around them...
}

"Some of the mental health issues that arise from incongruity - either the social or genital incongruity, probably the major one would be depression..."

(Natalie, 2011, interview). 
A poststructuralist theoretical theme emerges from Natalie's comments about societal power structures maintaining a rigid, conformist male/female binary code: those who do not conform - unintentionally or otherwise - to society's “checklist” (Matthews, 1984, p. 13) of separate male and female categories face discrimination and isolation. Natalie's comments also disrupt a dream of a postmodern utopian society (Whelehan, 1995, p. 199) where the male/female gender binary code does not exist - reality. However, while Natalie comments about the realities of social norms in relation to issues such as depression, she nevertheless asserts that an individual needs support in order to overcome barriers such as exclusion.

\section{Gender - "How would you describe yourself?"}

Mani Mitchell, who founded the Intersex Trust Aotearoa New Zealand (ITANZ), describes my interview question as a "complex one" (Mitchell, 2010, interview). Mitchell describes gender as "an evolutionary process, and certainly is not set in concrete at this point", and recalls that she had "lived within the binary construction... because that's all I knew" until 1996 when she met other intersex people at "the world's first-ever" residential retreat for intersex people in California (ibid.). However, prior to attending the retreat, she had begun undertaking educational- and activist-type work and remembers thinking that "there could be other possibilities outside the binary construction":

"For me that was exciting and terrifying. Exciting because for the first time in my life I had some matching... mirroring some reflection that had been absent up until then."

(Mitchell, 2010, interview).

She became aware of other cultures "where there is understanding outside the binary":

"I'll refer particularly to North American understandings of gender, because there was someone at the first retreat who, while not a Native American, had done quite a lot of research and had worked with some Twin [Two-]Spirit-identified people. ${ }^{61}$ So really I came back to New Zealand with this new information, but also with the work that I'd done up until then."

(Mitchell, 2010, interview).

\footnotetext{
${ }^{61}$ Two-Spirit: a Native American cultural identity which consists of "two spirits, one male and one female", in which mixed-gender roles occurred amongst most Native American tribes before European contact (Gilley, 2011, p. 127). The term Two-Spirit emerged amongst the Native GLBTIQ community when the work of Will Roscoe became popular in anthropology, Native American studies and "gay Native social circles" (ibid., pp. 126-127). As well as gender fluidity, the term also includes sexuality - hence "Native gay identity" (ibid., p. 123).
} 
Mitchell recalls how her father, a keen amateur photographer, took numerous photographs of herself and her siblings growing up as children (ibid.). Looking at these photographs years later, she describes how her childhood interests extended across gender stereotypical roles:

\begin{abstract}
"I was delighted to find a child who was both very comfortable doing traditional girl things - playing dress-ups, interest in fabrics - you know, the sort of things that would typically belong to a female child. But sitting right alongside that, I was also a child who delighted going out with my father - and it's funny, even more so than my brothers! I had learnt to and was able to drive a small farm tractor by the age of six. I knew all my dad's tools by name, I would love going out into the shed and he'd ask me to get his jackplane and I would know exactly which one that was."
\end{abstract}

(Mitchell, 2010, interview).

Mitchell also remarks that her occupation as a psychotherapist lead to an interest in language and that, drawing from information from her childhood and the present, she came to "an understanding" about herself (ibid.). As someone "who's not exclusively male or female", Mitchell describes how her attempts to "fit into that paradigm didn't work":

Who I am and who I live these days is somebody outside that normative construction. So I don't say that I'm male or female... there's parts of me that's both of those things, and it's not constant. There are days where probably I seem more female, and then there are other days perhaps where... if we're using English language I would seem more masculine.

(Mitchell, 2010, interview).

Mitchell's thinking prior to attending the first-ever retreat for intersex people, about possibilities of living beyond the male/female binary code, reflects a feminist poststructuralist perspective about "the possibility of moving beyond what is already known and understood" (Davies \& Gannon, 2005, pp. 319-320). Her recollection that this was "terrifying" further reflects another poststructuralist perspective about power which "forces" individuals to conform to "particular ways of being" (ibid., pp. 318), in which individuals who do otherwise may face harassment and discrimination. However, the "new information" that Mitchell gained from the retreat, including meeting someone who had worked with North American two-spirit peoples, may have been an empowering factor to become public (as she did in Pickersgill's 20/20 report in 1997) about her intersex self. This may have further empowered Mitchell to begin her activist work in educating others about intersexuality which, using feminist poststructuralist (ibid., p. 318) and postcolonial (Shields, 2010) perspectives, challenges Western 
society's regime of gendered subjectification into male and female categories.

Furthermore, Mitchell's childhood was free of gender "conditioning” (Millett, 1971, p.

31) and crossed male and female cultures.

Others feel comfortable in female categories:

"I'd describe myself female. Yeah... that's basically it. I might be a lesbian female but that's alright! [laughs]

“...medically I'm effectively female... I can have kids, so you can't really call yourself a male if you know what I mean [laughs]... so that's basically me and how I would describe myself I guess."

(Lisa, 2010, interview).

I asked Lisa why she thought a person could not describe himself as male, if that person was in fact physically capable of becoming pregnant - for example, a transgender man with a uterus and ovaries: ${ }^{62}$

"I guess it's more that I can't identify with that at all, I can only identify as a female. I'm a normal female chromosomally $[46, \mathrm{XX}]$, so as far as I'm concerned - female."

(Lisa, 2010, interview).

She further comments on how she describes herself:

"I don't refer to myself as intersex, and I think that's a CAH thing."

"I am very, very conscious that some people find the term offensive."

"Yeah, I don't term it offensive either... I don't associate with it. You know, I associate as being a girl with CAH, and that's what I am."

(Christmas \& Lisa, 2010, interview).

\begin{abstract}
I asked Lisa why she considered it was "a CAH thing" to not describe oneself as intersex:
\end{abstract}

“I don't really know. Like my perspective of intersex up until now has been people who are chromosomally mixed ["mosaic"], so they've got a bit of both in them. So for me that's what I've always sort of thought intersex has been."

(Lisa, 2010, interview).

\footnotetext{
${ }^{62}$ I referred to Thomas Beatie (b. Tracy Langondino, 1974) who in June 2008 gave birth "naturally" to a girl in Bend, Oregon. During his female-to-male transition Beatie, whose wife Nancy had previously underwent a hysterectomy for medical reasons, kept his female reproductive organs as he wanted to retain his "reproductive rights", remarking: "Wanting to have a biological child is neither a male nor female desire, but a human desire". In July 2010 Beatie had given birth to two more children - all conceived via artificial insemination with donor sperm (Pilkington, 2008; Childs, 2011).
} 
Lisa's older sister Jacqui also describes herself as female and, like Lisa, associates the ability to become pregnant with identifying as female:

\begin{abstract}
"I am most definitely a female - most definitely! [laughs] I mean when I was - well in the gestation period I take it, things were a bit AWOL you might say with the congenital adrenal hyperplasia, but the genes are most definitely female $[46, \mathrm{XX}] \ldots$

"So yeah, when it goes through all the chromosomal tests that's what it is so, yep - and obviously I am because I've got the little man [her infant son]! [laughs]"
\end{abstract}

(Jacqui, 2010, interview).

Anonymous 3 also describes herself as "definitely female":

\begin{abstract}
"I'm pretty happy with what - well pretty much my mother and my father decided when I was born, and I think they made the right decision. I'm happy with being a female, I don't think I'd ever want to be a male."
\end{abstract}

(Anonymous 3, 2010, interview).

Sarah comments that, as far as she knows, most of her organisation's members (which include adults with $\mathrm{CAH}$ ) do not identify as intersex - particularly girls with $\mathrm{CAH}$, and that parents refer to their children as "our daughter" or "our son" (Sarah, 2010, interview). Sarah then talks about "appropriate language" and "allowing the patient to own their own reality":

\begin{abstract}
"Of course if a girl wants to call herself intersex, as Mani [Mitchell] calls herself intersex, that's good and proper, it's the right thing to do. But I've offended some of the women well one woman - in our support group by using the term intersex once, not calling her intersex but using that as a general term. She was incredibly offended, because she did not identify as that. So she didn't even want me talking about that in connection with the condition, because for her it was offensive."
\end{abstract}

(Sarah, 2010, interview).

These comments by Lisa, Jacqui, the young adult woman and Sarah counter Butler's argument which proposes to dismantle the male/female binary code (Butler, 1990, pp. vii-viii). While Lisa acknowledges that others with CAH may identify as intersex and Jacqui is aware of gender fluidity, and while women have experienced oppression throughout history because of their classification as female, these three women are nevertheless content with this classification. In contrast to Wittig's (1992, pp. 80-81) argument, I argue that gender should not necessarily be destroyed as women have every right to describe themselves as female and not experience oppression. However, Rogena firmly states: 
"I would describe myself as me, not as male, not as female, but just as me. And that's where I think intersex sits - it's not a male, it's not a female, it's an intersexual identity which you can't describe as either."

(Rogena, 2011, interview).

S/he believes that intersex identity is an individual matter for a person to be "[their] own intersex identity" (ibid.). Rogena began to describe hirself this way when s/he undertook research on surgery for hypospadias:

\begin{abstract}
"After doing some research into my operation that I had when I was a kid, and wondering possibly if that had anything to do with fertility problems, that research led me to understand me as myself. And then everything clicked into place, and then I felt comfortable with that I am who I am, and I don't need to be 'this side' or 'this side'."
\end{abstract}

(Rogena, 2011, interview).

Rogena tells me why s/he dislikes the word "gender" which, s/he remarks, is a "dirty word":

\begin{abstract}
"Gender is not biological, it's not natural, it's a social construction. So although sex is biological the social construction of sex, which has now become gender, is - I used the term 'dirty word' because it's not natural, it causes more problems in our patriarchal society than it serves and helps. So when we look back at all the problems we have ranging from domestic violence, ranging through to intersex issues, through to other aspects of our life including pay discrimination, when we look at the whole gambit it's pretty dirty."
\end{abstract}

(Rogena, 2011, interview).

Rogena's dislike of the word "gender", that it "causes problems" in a patriarchal society resonates with Wittig's (1992, pp. 80-81) argument that gender (as a word in language) is particularly oppressive to women. Rogena's assertion that s/he feels no need to be male or female, after finding out about surgery during childhood, also reinforces Cox et al.'s (1997, p. 191) argument about crossing gender boundaries - that gender is inessential. As I stated before, while women have experienced discrimination because of the very word "female", I nevertheless argue that people - irrespective of anatomy (such as transwomen who have not undergone surgery) - have the right to identify as female and not experience oppression. But while Natalie (2011, interview) comments that people's perceptions of a person can affect that person's mental health, in terms of social exclusion, she still believes that health professionals should support a person so that they can participate fully in life. I therefore suggest that, once a person receives support, gender may become less of a "dirty" issue. 


\section{Conclusions}

This chapter highlights the importance of support for people with variations of sexual anatomy, in which narratives suggest this is particularly so during an individual's teenage years. Jacqui's (2010, interview) comments suggest that support is crucial during adolescence when, as she said, a person is more "self-aware" (albeit feeling more vulnerable) amongst their peers. Easily-accessible counselling, I suggest, could also assist in alleviating any mental health issues such as depression associated with peer exclusion (Natalie, 2011, interview). Indeed, easily-accessible counselling may have alleviated the depression that Jacqui has experienced (Jacqui, 2010, interview).

Anonymous 3's experiences of surgery were more positive than Jacqui's and Lisa's because of, I suggest, peer support. Unlike Jacqui and Lisa, Anonymous 3 had a close friend with $\mathrm{CAH}$ who was with her in hospital. The CAH support group ${ }^{63}$ that Jacqui mentioned also did not exist when she and Lisa underwent their earlier surgeries which they prefer to "block out" - whereas the group was well-established when Anonymous 3 underwent her second surgery at the age of 11. This suggests that, with no support group available, Jacqui and Lisa (like Rogena) may have felt very isolated when they underwent their earlier surgeries during adolescence.

Another issue that arises from lack of support - and indeed lack of information - is silence. In this case, Jacqui's mother experienced being silenced by judgemental reactions from other mothers in her local Plunket group which, as Jacqui remarked, created stress. Jacqui's own experiences about keeping silent about hospital visits to her peers during teenage also suggest that she was afraid of negative reactions (as her mother experienced) and peer exclusion. But aside from social factors silence on practical aspects, such as using vaginal dilators correctly, can result from not only embarrassment but a lack of information. In the case of the teenage girl that Sarah (2010, interview) talked about, there was no one available to instruct her on how to use dilators correctly. It was when the girl made contact with a support group (Sarah's) that her silence over a practical issue was resolved. Education from support organisations

\footnotetext{
${ }^{63}$ In order to ensure confidentiality I have withheld details about this support group.
} 
such as Rainbow Youth, which will be discussed in the next chapter, is the key to resolving silence about "be[ing] different sexually" (Hillman; in SFHRC, 2004). 


\section{Chapter 12: \\ Education and awareness - different approaches to sexual differences}

In this chapter I will discuss different approaches to education about intersexuality in New Zealand, with regard to findings about typical and variances of sexual differentiation (chapter 5) and the clinical management of intersexuality (chapter 9). I will first outline findings when I attended two lectures at Auckland Medical School, two seminars at the Christchurch School of Medicine and one midwifery lecture. Next, I will outline the training undergone by two specialist clinicians (a paediatric surgeon and a plastic surgeon) and two registered nurses. I will then outline the education given by Rainbow Youth, a community/support organisation that provides education about gender and sexuality issues to groups such as secondary (high) school students and nursing students. Finally, with regard to intersex people's rights, I will outline Georgina Beyer's motives for introducing the Human Rights (Gender Identity) Amendment Bill to the New Zealand government.

Though I only attended a few lectures and seminars, and interviewed a few health professionals and organisation representatives and one former MP, I will discuss their differing perspectives on intersex and gender issues. From my findings, medical institutions appear to focus on the management of intersex conditions, whereas nursing, midwifery, community and government institutions appear to promote acceptance of intersex variations.

\section{"Reproduction and Endocrinology" lectures - Auckland Medical School}

I attended two MBChB303 ("Reproduction and Endocrinology") lectures at Auckland Medical School, part of The University of Auckland, which were conducted by

Professor Paul Hofman. At the first lecture Hofman commented that he sees 15 to 20 cases of ambiguous genitalia a year and outlined the exam goals for the MBChB303 course: one was being "able to define basic defects [sic] in sexual differentiation", and another was to "work out a diagnosis of an undervirilised male and an overvirilised female" (P. Hofman, personal communication, 7 May 2007). He commented that it is "very difficult for the family with a baby with a large penis... when they find out it's a 
girl, it's psychologically difficult" (ibid.). Hofman instructed that, when assessing a child with ambiguous genitalia, "two urgent things" should be undertaken: a karyotype analysis and a pelvic ultrasound scan (USS) (ibid.). He said that a USS can "accurately determine internal female genitalia" (a uterus and/or a cervix which "are large at birth" due to exposure of maternal oestrogens) and that the lack of internal female genitalia nearly always indicates the presence of a functional testis (ibid.). Hofman advised that it is "important to tell the parents [in order] to get this sorted out as fast as possible... because it does cause consternation" (ibid.). He then advised to "check for a palpable gonad - it will almost be a testis" - thus "if you can feel gonads they're most likely to be testicles, so the karyotype will likely be XY [male]" (ibid.).

Another PowerPoint slide during the first lecture contained four photos of ambiguous genitalia and Hofman asked the students, "What do you do? Do you make these children become female or male?" (ibid.). Androgens, he said, "have an influence on sexual orientation" and there is a "higher incidence of homosexual and tomboyish behaviour" in children with CAH (ibid.). He also commented that "most of us will consider leaving these children alone and letting them decide for themselves" (ibid.). At the end of the one-hour lecture there was an opportunity for students to raise questions. In response to a student's question about "letting children decide themselves if he or she wants to be a boy or a girl", Hofman said that, as a "high incidence of lesbian behaviour" occurs amongst CAH individuals, he recommends early surgery as "they identify as female" (ibid.).

The second lecture I attended included case studies of two children with $\mathrm{CAH}$, one of whom was diagnosed with $17-\mathrm{OH}$ progesterone deficiency (see chapter 5) in which the Guthrie card test showed a "markedly elevated" result (P. Hofman, personal communication, 12 May 2008). Two PowerPoint slides contained a close-up photograph of the child's ambiguous genitalia, with a statement that the child's karyotype was 46,XX and that an ultrasound scan "shows normal uterus" (ibid.). Hofman asked, "How should this child be raised? Should you raise it as a boy or a girl?" (ibid.). In the large, packed lecture theatre more students raised their hands when Hofman asked, "Who thinks you should raise it as a girl?" (ibid.). He said that some children with $\mathrm{CAH}$ have been brought up and have "functioned as males", but that most 
children "raised as girls" are referred to Royal Children's Hospital in Melbourne for feminising surgery (ibid.).

With regard to the students' responses to Hofman's questions, I suggest that they, like many others, are not judgemental but unfamiliar with intersexuality. It is likely that many medical students may be unfamiliar with theoretical perspectives about sex and gender - particularly as a medical faculty is different from an arts faculty. Prior to attending Hofman's lectures, the students may have also never encountered intersex matters before. Hofman also suggests that children should be allowed to choose whether or not they wish to undergo surgery, and indeed shows an awareness of intersex activist work. When I met Hofman briefly before the first lecture, he asked me if I had heard of Mani Mitchell and the ISNA.

\section{Paediatric surgery seminars - Christchurch School of Medicine}

Professor Spencer Beasley says that the sixth-year (undergraduate) medical students at Christchurch School of Medicine are only taught briefly about intersex conditions which are covered in two lectures: "Inguinal Scrotal Region" and "Neonatal Surgery", the latter which covers "neonatal emergencies" such as the salt-wasting form of CAH. In one or both lectures students are taught about "how do you recognise that the gender may be indeterminate?", "what do you do if you can't tell if it's a boy or a girl?" and the importance and reasons that this "needs to be sorted out quickly" (S. Beasley, personal communication, 12 November $2007 \& 16$ August 2008). Students are also taught to refer the parents and child to an appropriate specialist (initially a paediatric endocrinologist or paediatric surgeon) who, Beasley said, has the knowledge and skill required to deal with the clinical and emotional needs (ibid.).

Compared to undergraduate lectures, DSDs (sic) are covered in far greater depth for postgraduate students undertaking specialist training in paediatric surgery in New Zealand, where only two training posts occur in Auckland and Christchurch (S. Beasley, personal communication, 12 November $2007 \& 16$ August 2008). The training is usually of six years duration and ends when postgraduate students sit their final RACS (Royal Australasian College of Surgeons) Fellowship exam (ibid.). Beasley himself is 
currently the senior examiner for paediatric surgery of the Royal Australasian College of Surgeons (RACS), which involves all paediatric surgical trainees from Australia and New Zealand (ibid.). RACS, Beasley said, could set written questions about DSDs and other related topics, or questions on DSDs during the clinical examination when they examine a baby with a DSD (ibid.). DSDs and other related topics are particularly covered in greater depth for SET in paediatric surgery as, Beasley says, their training will ultimately result in them being consultants in paediatric surgery and as such they need to have knowledge of these conditions (ibid.).

Two seminars for sixth-year medical students about the inguinal scrotal region and penis form part of a six-week series of lectures at the Christchurch School of Medicine, and are run in cycles throughout the year (ibid.). I attended these seminars, conducted like tutorials, with six trainee interns (TIs). At the beginning of one seminar Dr Adrian Skinner, a paediatric surgery registrar who conducted the seminars, talked about urogenital matters (as part of embryology) which included aspects on how female and male genitalia develop, and "abnormalities" such as cloaca ${ }^{64}$ and hypospadias (A. Skinner, personal communication, 29 April 2008). The first slide of a PowerPoint presentation contained a close-up photograph of an empty scrotum and a penis deficient of tissue, and the second slide contained a close-up photograph of chordee (bent penis) that Skinner remarked was caused by a deficiency in tissue (ibid.). The effects this can have on a boy, Skinner said, are:

- $\quad$ psychological;

- difficulty with intercourse - "not how God designed to engage with female genitalia";

- $\quad$ chordee causes misdirection of the urinary stream: "Can't direct pee well, when the little boy can't participate in games such as aiming at the door etc.!"; and

- less success in future sexual relationships with a woman because the erect penis is very bent (ibid.).

\footnotetext{
${ }^{64}$ Cloaca: terminal part of the embryo's hindgut which divides into the rectum and urogenital sinus (Oxford, 2003, p. 139). The hindgut is the terminal part of the embryo's gut which develops into part of the large intestine, rectum, bladder and urinary ducts (ibid., p. 318).
} 
The "psychological" effects that Skinner commented on echoes Natalie's view (in chapter 11) about mental health issues such as depression arising from genital "incongruity": that individuals whose appearance falls outside social norms may experience exclusion (Natalie, 2011, interview). And while clinicians should realise that some children may grow up to become gay or lesbian, I agree with Skinner's comment that chordee may affect other boys psychologically who, when they get older, do desire heterosexual relationships. A medical study involving 52 men noted that, amongst the younger men, "penile length and chordee were the most embarrassing issues" with regard to psychosexual and life satisfaction issues (Woodhouse et al., 1983; in Ben-Chaim et al., 1996, p. 1252). However, paediatric urologists Gerald Mingin and Laurence S Baskin comment that, despite the improvement of surgical techniques to correct chordee, "none are without complication" (Mingin \& Baskin, 2002, p. 283). Though they recommend surgery during an individual's first year of life, Mingin and Baskin comment that long-term results after puberty have yet to be evaluated to confirm positive outcomes of surgical techniques (ibid., p. 283; Baskin; in Yucel, Sanli... \& Guntekin, 2006, p. 703). Other paediatric urologists state that risks from surgery include shortening of the penis and pain during erection (Yucel et al., 2006, p. 701) and that, despite early surgery, chordee may reappear during puberty (ibid., p. 699).

Another PowerPoint slide was about "Undescended Testes and Inguinal Hernia" which noted underneath "Orchidopexy ${ }^{65}$ at time of herniotomy" (A. Skinner, personal communication, 29 April 2008). Skinner advised that "the boy should be born with testes in the scrotum" as, if they are not in the scrotum by the age of two, then damage starts occurring to the testis which affects maturation of the spermatozoa (A. Skinner, personal communication, 29 April 2008; S. Beasley, personal communication, 16 August 2008). A further slide showed a case of ambiguous genitalia where both a penis and a clitoris (positioned underneath the penis) were surrounded by bilateral "flaps" which resembled a labia majora (A. Skinner, personal communication, 29 April 2008). The anus was visible below the genitalia which had no visible vagina (ibid.). As I remarked to Skinner and the other interns, during my extensive reading of medical texts I had never encountered a case as unusual as this. I therefore appreciate that some

\footnotetext{
${ }^{65}$ Orchidopexy: a surgical procedure where an undescended testis (cryptorchidism) is mobilised then fixed in the scrotum (ibid., p. 490).
} 
parents may find a case like this distressing, particularly when considering Mitchell's view (in chapter 9) that denying genital surgeries may be "catastrophic" for some family situations (Mitchell, 2010, interview).

Skinner commented on the "dilemma" of male or female sex assignment, and that my research topic is a "nightmare area" for those early in their training as, he said, it is "so complex" (A. Skinner, personal communication, 25 April 2008). Skinner also said he was interested in the progression of my research and that I was welcome to attend further seminars: "We don't get taught enough of it in paediatric surgery," he said, and that Christchurch Hospital's lecture series in paediatric surgery covers "very little" about intersex, gender assignment and gender identity issues (ibid.). However, to be fair Skinner is not expected by his consultants to yet have detailed knowledge of DSDs, nor to be required to teach detailed information on this topic to TIs (S. Beasley, personal communication, 16 August 2008). Beasley himself "initially" underwent training in adult general surgery and gained a fellowship of the Royal Australasian College of Surgeons in that specialty (Beasley, 2010, interview). He then underwent training in paediatric surgery which was "largely undertaken" at the Royal Children's Hospital in Melbourne (ibid.). This included a year focusing on paediatric urology which involved cases of ambiguous genitalia (ibid.). I ask Beasley if his training included gender studies, such as "appropriate gender assignment" to a specific intersex condition:

"This occurred in the early to mid-80s and, up until that time, most of the focus in the management of these conditions had been around establishing the appearance of normal anatomy, usually either male or female. And relatively little was known about some of the other psycho-social or more complex concepts around gender assignment patterning of the brain, the relationship between chromosomes and endocrinology, and lot of the other issues that we're much more familiar with now. So historically it was in the early days, and there wasn't as nearly as much understood as now.

"I do remember in 1985 I went to a conference in the US where there was some discussion in relation to congenital adrenal hyperplasia, and some of the behavioural or self-identity matters that came up later on. That was the first time I suspect that it was really aired in the medical arena, but [that] there may be some major issues about gender assignment."

(Beasley, 2010, interview).

\section{Mr Chris McEwan - plastic surgeon}

Chris McEwan recalls that, while his undergraduate training at Otago University covered "the biochemistry and embryology of development", it did not explicitly cover intersex matters: "other than making an observation that there's variation and intersex, 
and that gender by appearance is a little misleading on occasions" (McEwan, 2010, interview). His undergraduate training included work as a house surgeon at Wellington and Lower Hutt public hospitals, where he was involved in providing healthcare to the transgender community:

"I used to do locum work with one of the central city general practices in Wellington that had one of the big houses up on the hill, that was occupied by the girls from the balcony which was quite an entertaining place to go, and quite an entertaining group too! But that doesn't constitute training, but it constitutes experience."

(McEwan, 2010, interview).

McEwan also spent three years working at the Mayo Clinic, USA, where there is a "significant practice" on intersex conditions (ibid.). Since returning to New Zealand he has, from 1995, been involved with an Auckland private practice where his continuing work has been mostly with transgender rather than intersex individuals (ibid.). When I asked if his training ever covered gender issues such as "appropriate gender assignment" for specific intersex conditions, McEwan said that this occurred "a long time ago" and that the "concept" of gender identity was not discussed a lot back then:

"We did have a 'Good Behavioural Sciences' thing that did touch on the variance in sexuality, but the whole idea of managing an intersex at that point in time was, I would argue, compared with now, extremely primitive. And a lot of the bad things that you think of, when you're talking about the assignment of gender and bits and pieces, were things that happened in that time. As an undergraduate there was very little teaching on that - it really is a highly specialised thing, it's not something that you do. But there was a reasonable discussion, it was in the time that feminism was in ascendancy and so the whole idea of what gender represented and bits and pieces was discussed a lot.

“...we had a fairly radical 'Behavioural Sciences' programme that actually kind of said, 'Look, this is all important and you need to know it'. But the trouble during undergraduate time is that the concentration is passing exams - you don't have a perception of what practice involves, and if you did you'd redesign your undergraduate completely into learning taking oral history and doing all this other stuff, which is around people management, than it is necessarily learning the biochemical basis of cellular reactions or whatever."

(McEwan, 2010, interview).

McEwan says that medicine, as a branch of science, is "a philosophy" and that his chosen field of plastic surgery "is as much based in art and psychology as it's based in science" (ibid.). I asked McEwan to elaborate more on his postgraduate training and overseas experience, particularly with regard to gender diversity: 
“Growing up in New Zealand, you can't but know about fa'afafine - or at least if your eyes are open! That's not to say all doctors' eyes are open because they're not. I think, leaving aside training, leaving aside the professional side of things, I think I was aware of the variance of gender all of my life."

(McEwan, 2010, interview).

McEwan believes that, in order to work with intersex and transpeople, clinicians must have "a capacity for acceptance, which not every person has" (ibid.). If clinicians do not have that capacity, he advises that they should specialise in areas such as orthopaedic surgery "where it doesn't matter" (ibid.). McEwan says that "[a]s a plastic surgeon, there's a lot of expectation that you have the understanding of the pathophysiology of intersex", but he believes that gender is fluid and that the specialty of plastic surgery is compatible with this:

\footnotetext{
"Plastic surgery teaches you, if anything, that there is no single answer to anything at all. The advantage of plastic surgery is that you've got 110 ways to do something, which allows you to select the most appropriate way for your individual patient. ...

"So from that point of view then it's pretty straight forward that gender isn't bipolar. It's a continuum. There's two bulges, there's a bulge at either end and there's something that joins the two of them, and where you are I think changes with time.
}

"So to consider it's a binary code suggests that it's immutable and separable. It's neither of those things, it changes, people change and therefore the concept of where they fit in the gender spectrum probably also changes too - or at least I'd be staggered if it didn't!'

(McEwan, 2010, interview).

McEwan offers a more philosophical perspective about gender, in that he recognises the concept of fluidity and a continuum beyond societal assumptions of only male and female classifications. Indeed, I suggest that his exposure to feminist discussion (of "what gender represented") in his medical school days and his work with the transgender community further contributed to this awareness of gender diversity. Beasley too shows an awareness of different states of engenderment, as he remembers when this matter was first raised in medical circles 30 years ago - and he notes differences in opinion amongst some clinicians.

From my findings, while Hofman and Beasley's views appear to focus on establishing a sex assignment quickly, McEwan offers a differing view in that there is more than one way to manage a condition. However, one should consider that McEwan's specialty is plastic surgery whereas Hofman's and Beasley's is paediatrics. Some of Hofman's and Beasley's patients are babies and small children who cannot talk. Hofman and Beasley 
therefore have no choice but to communicate with their parents who, with regard to Sheryl's comments (in chapter 9), may be very stressed about their child's condition.

\section{"Identity and Diversity" lecture - midwifery programme}

As well as medical lectures and seminars I attended a lecture about "Identity and Diversity" which was conducted by Jeanie, a Midwifery Programme Director, at a tertiary institute in New Zealand. ${ }^{66}$ While the few medical lectures I attended focused chiefly on anatomical aspects of intersexuality, this lecture tended to focus on societal perceptions about gender, such as the relationship of gender to women's and men's health. The lecture included aspects such as gender stereotypes and the gender binary ("one or the other"), societal constructions of masculinity and femininity, the notion of "reproduction of the species" ("women as child-bearers and carers"), and messages and meanings given to bodies (Jeanie, personal communication, 7 September 2010).

During the lecture Jeanie asked the students to discuss amongst themselves ways of "doing gender" and "how gender is done to us" (ibid.). After the discussion the students raised matters such as:

- $\quad$ children's toys - hence gender stereotypes

- "gender/sexual panic" - confusion about "is it a man or a woman?"

- $\quad$ activities such as ballet and sports

- hairstyles: boys with long hair - "what a gorgeous girl!", to which Jeanie commented that "strong assumptions" are made

- household tasks such as cooking

- girls - "tomboys", compared to boys who do dancing - "gay" (ibid.).

Jeanie first encountered the topic of gender diversity during the 1980s while studying for a Bachelor of Science degree majoring in psychology, when she read about studies undertaken in the 1970s and 1980s (Jeanie, 2011, interview). She believes that she first became aware about intersex issues in 1996 when she was appointed Head of Midwifery at Wellington Polytechnic (now Massey University), and her colleagues were

\footnotetext{
${ }^{66}$ As Jeanie requested that information be modified I have withheld details of this tertiary institute in New Zealand.
} 
implementing the Inaugural Bachelor of Midwifery in the Wellington region (ibid.). Drawing from her previous experience in women's health, she taught a paper titled “Women's Health and Sexuality" (ibid.). Jeanie, who underwent apprentice-style nursing training from about 1965 to 1967 , has been interested in politics for most of her adult life (ibid.). She recalls that she first learnt about gender issues during the early 1970s when she studied a Social Policy paper at Victoria University, and that the paper included debates on events which subsequently led to the passing of the Homosexual Law Reform Bill (ibid.). ${ }^{67}$ In the mid-1970s she became a member of the Women's Electoral Lobby ${ }^{68}$ which "was a time of great change with the women's movement becoming very active", and that abortion ${ }^{69}$ was "a very big issue" during what was "a very political and controversial time" (ibid.).

During her nursing training Jeanie recalls that she "wasn't really aware" of any women who had had babies born with intersex conditions (ibid.). Jeanie was also unaware of any intersex babies born during her time at St Helen's Hospital ${ }^{70}$ where she underwent midwifery training during 1969, and subsequently became a charge nurse/midwife at the hospital's busy midwifery unit:

\begin{abstract}
"In those days there was very little education pertaining to genitalia - let alone variations in genital development. I think variations of genitalia were referred to as 'aberrations' in textbooks, and not given much space as I recall. If they did they were largely attributed to some chromosomal condition."
\end{abstract}

(Jeanie, 2011, interview).

\footnotetext{
${ }^{67}$ On 14 November 1985 the Homosexual Law Reform Bill was passed by the New Zealand Government which decriminalised sex between men aged 16 and over (Laurie, 2009, p. 20). Though sex between women was not illegal (ibid., p. 15), like gay men many lesbians became active in the homosexual law reform movement (ibid., pp. 17-18).

${ }^{68}$ In New Zealand the Women's Electoral Lobby was a collective of women's groups, as well as women from "all sectors of society" with a variety of interests. Its key philosophy was to get more women elected into Parliament (Jeanie, 2011, interview).

${ }^{69}$ From May 1974 women in New Zealand could only obtain abortions privately via the Auckland Medical Aid Society (AMAC) which established a clinic, but in September 1974 a police raid on the clinic resulted in Dr James Woolnough "being charged with 12 counts of procuring illegal abortions". Though Woolnough was acquitted a subsequent High Court appeal "failed to overturn the not guilty verdict". Much public debate led to the New Zealand Government passing the Contraception, Sterilisation and Abortion Act on 15 December 1977, which was amended in July 1978 (Auckland Women's Health Council, 2012).

${ }^{70}$ St Helen's Hospital (now closed) was founded by Dr Agnes Bennett to focus on maternal health. It was, as Jeanie remarked, "an absolute paragon of a modern maternity hospital". It was "a lovely place to work in" because of its modern facilities, and that "most women [and their babies] had a single room to themselves" (Jeanie, 2011, interview). The building still stands in Colombo Street, Newtown, Wellington, New Zealand.
} 
She further remarks that her training, "working largely in the clinical situation, coming out occasionally into the school for the theory", did not include gender issues at that time (ibid.). Jeanie was also a charge nurse at Wellington Women's Hospital where again she did not encounter any newborn babies with ambiguous genitalia (ibid.). She has read publications by Butler and, in undertaking her own research, she had studied postmodernism and poststructuralist feminism in relation to language on "how certain discourses in society can shape reality through language use, and how powerful that language can be in terms of labelling" (ibid.). Her lectures on the topics of gender, intersexuality and gender orientation have always been received positively by students, especially when Mani Mitchell has been invited to give lectures:

"They seem to have gained much from those lectures on gender - many of whom have never heard of intersexuality or matters of gender, [they] have really appreciated the lectures on gender and intersexuality."

(Jeanie, 2011, interview).

Jeanie also remarks that Mitchell has been "very supportive of our students" and that students "have loved the lectures and tutorials she's had with the students - they've really valued the contribution Mani has made" (ibid.). During tutorials the students form into groups and work with scenarios, such as using appropriate language, using an ISNA-produced resource containing stories and scenarios (ibid.). Each group then tells the whole class about their ideas for particular scenarios. Mitchell also attends and contributes to these tutorials which form part of an entire day course on intersexuality, and prior to the course students spend an intensive one or two days discussing gender issues (ibid.). I asked Jeanie about the type of advice or support that she and other guest lecturers such as Mitchell give to midwifery students, in the event of parents becoming upset when their baby presents with ambiguous genitalia. As well as first advising parents that "there is no panic", her advice reflects her study of postmodern and poststructuralist feminism in relation to language:

\footnotetext{
"There may be some assessments in terms of assessing a condition that may be a healththreatening matter [e.g. salt-wasting CAH types] for the baby, but that can be done in terms of helping the parents come to terms with their baby's different genitalia, giving them support networks - help that they can get, rather than have their babies whisked away, because that situation used to cause a bit of panic when they saw a baby with different genitalia. Many midwives now in practice - and we talk a bit about this in class - will let the parents see the baby's sex or the baby's gender, and let them decide rather than saying aspects like, 'Ooh haven't you got a beautiful baby boy or a baby girl.' It may be, 'Haven't
} 
you got a beautiful baby.' So we talk about these matters in terms of softening the language, rather than using binary of 'boy/girl'."

(Jeanie, 2011,interview).

While I only attended a single midwifery lecture and a few medical lectures, the latter appears to focus on anatomical aspects of intersexuality. The midwifery lecture appears to focus more on intersexuality's social aspects, such as how society constructs sex and gender, and how these constructions influence societal perceptions of normality. Medical lectures did, however, include ethical considerations, such as Hofman's suggestion that children should decide themselves whether or not they undergo surgeries.

\section{Registered nurses}

Deborah, a registered nurse (in chapter 9), became interested in intersex issues during the early 1990s when, at the hospital where she worked, six or seven babies with variations of sexual anatomy were born within a year:

\footnotetext{
"We had a year where we had I think six or seven intersex babies born, and so this was a case presentation of all those babies and a follow-up of the medical paradigm at the time, and what should be done for these babies. And at the time I just thought, 'No, it just doesn't seem right to me,' so that started my interest."
}

(Deborah, 2011, interview).

I asked Deborah to elaborate on why she did not feel comfortable with the "medical paradigm" at the time:

\footnotetext{
"Just that you would do surgery on a child's genitals, on a child that was genetically XY, to try and confer a female gender on them. Or that you do genital surgery on a girl with an enlarged clitoris. This was just after I came back from America and had spent a year in the gay community over there. I guess my idea of what defines male and female, and what defines your gender, is probably different from a lot of people. I see a lot of people for whom gender is a more fluid issue. Also at the time there was just starting to be some stuff in the gay press about intersex issues - that was probably the start of intersex becoming a more political issue."
}

(Deborah, 2011, interview).

Deborah's interest in gender issues was also fuelled by a gender and women's studies paper she studied at university (ibid.). She also recalls that growing up with "a whole lot of lesbian feminists" already provided knowledge about gender issues, regardless of formal study she undertook: 
"I was surrounded by drag queens, fa'afafines and other people who had made a conscious choice to identify with a different gender. So even though it wasn't covered in any of the training I've done it's just knowledge I have anyway. I was also involved with Rainbow Youth."

(Deborah, 2011, interview).

Similarly with McEwan's life-long awareness of gender variance (McEwan, 2010, interview), I suggest that Deborah's exposure from a young age to diverse communities who rejected two-sex, heterosexual norms influenced her perspective about gender particularly the construction of male and female categories. Deborah's approach to parents also differs from Sheryl's (in chapter 9) in that anatomy does not influence gender identity, whereas Sheryl "assures" parents on their child's assigned sex by rechecking test results. However, as discussed previously, Sheryl's approach appears to derive from a strong empathy and genuine concern towards parents who may be very upset when ambiguity in their children's genitalia is identified by clinicians.

Leigh McCarthy, another registered nurse, prepared a pamphlet titled A Girl or a Boy? in order to provide an information resource for parents "when a baby's gender is uncertain at birth" (McCarthy, 2009, pamphlet). The pamphlet drew on McCarthy's research towards her Master of Philosophy she completed in 2008 (McCarthy, 2011, interview). That same year, at a neonatal conference in Christchurch, she presented a paper that drew from her research on A qualitative descriptive, exploratory study examining the information needs of four key stakeholder groups in regard to parental information needs when a child is born intersex (ibid.). ${ }^{71}$ McCarthy's motives for preparing the pamphlet arose from her research when she sought to investigate parents' information needs "when a baby's gender is uncertain at birth": a finding was that "parents are just lost when this happens, and that all they want is information" (ibid.). Her awareness of intersex babies at the neonatal unit she worked at made her realise that there were no information resources for parents (ibid.). McCarthy's wish for "something practical" for parents as an "end result" of her research thus resulted in the pamphlet, and her work with a support group for parents of intersex children further

\footnotetext{
${ }^{71}$ End-of-study report presented at Northern Region Ethics Committee (part of Ministry of Health), 8 April 2008, Penrose, Auckland (source: Ethics Committees website, www.ethicscommittees.health.govt.nz).
} 
resulted in a "kit""72 for parents of CAH children (ibid.). The pamphlet conveys intersexuality as a variation instead of a pathological condition, and encourages parents to be present with their children during tests and ask questions. The last paragraph is also similar to Nataf's queer theoretical argument that gender can be a fluid entity which does not need to be validated by clinicians (Nataf, 1996, p. 18):

“...we'd like to reassure you we see a number of babies each year whose genitals are different from what you might expect to see in a female or male baby. Although your baby has a condition you have probably never heard of, these conditions are not that uncommon. $\cdots$

You can be present for all these tests and hold your baby throughout them when possible, or immediately afterwards. You can ask as many questions as you like and we will explain what we are doing at the time.

"We suggest you choose the gender your baby is most likely to identify with as they grow up but it's important to keep in mind that all people - whether or not they have a genital variation make this decision as they mature, and may choose not to identify with the gender they've been given as a baby."

(McCarthy, 2009, pamphlet).

McCarthy says that the pamphlet is designed to be given to parents before any diagnosis is made:

"So this pamphlet is aimed just at those parents whose baby has ambiguous genitalia as it's [sic] called. It's linked to our protocol at work now, so that anybody who reads the protocol can go and print off a copy and take it with them."

(McCarthy, 2011, interview).

She says that the response to her pamphlet has always been positive (ibid.). As well as a support group which has distributed the pamphlet (and CAH kit) to parents, McCarthy has also been contacted by nurses, midwives and clinicians who have seen it and asked for copies - or more if they have run out (ibid.). She also received input from paediatricians and endocrinologists, "the kind of people who go on to see these babies", towards the pamphlet's wording and layout (ibid.). McCarthy and her colleagues have also endeavoured to distribute the pamphlet and CAH kit throughout New Zealand:

"So they've gone to all the nurse specialists, they've gone to all the neonatal units, they've
gone to a list of paediatricians that the endocrinologists at Starship [children's hospital in
Auckland] gave me, they've gone out to a list of paediatricians all over New Zealand. So
the aim is to try and get everybody getting the same information."

(McCarthy, 2011, interview).

\footnotetext{
${ }^{72}$ As well as the pamphlet, the "CAH kit" also includes laminated cards (so that parents, using an erasable marker pen, can keep track of their children's medication dosages) and support group contact information.
} 
McCarthy remarks that, while the percentage of babies born with ambiguous genitalia in New Zealand per year is small, she has distributed "hundreds" of pamphlets and has received requests for more (ibid.).

I argue that, had McCarthy's pamphlet been available to the parents I interviewed (in chapter 10) when their children were born, much stress may have been alleviated. Her advice that the pamphlet should be given to parents before diagnosis may, I suggest, alleviate any shock or bewilderment about an unfamiliar condition as two mothers (Anonymous 1 and Anonymous 2) recalled. This is because the pamphlet's easy-toread, calming language shifts intersexuality from a pathological construction to a anatomical variation that, as McCarthy states, is "not that uncommon" (McCarthy, 2009, pamphlet). She also conveys awareness about gender fluidity in that some people may choose to identify differently from their birth gender (ibid.). With regard to health concerns, the pamphlet would have indeed helped Sarah who had a particularly stressful experience with her son's blood tests and who felt disempowered to ask questions (which the pamphlet encourages) because of her local hospital's hierarchical culture.

\section{Rainbow Youth}

Like the midwifery lecture, a focus on acceptance and diversity is strongly prevalent at Rainbow Youth, an Auckland regional organisation (part of a national network of queer and trans youth organisations) "that provides support, information, advocacy and education for queer ${ }^{73}$ young people and their families" (Rainbow Youth, 2010). A large part of Priscilla Penniket's role as Education Co-ordinator is conducting classes at secondary schools (often as part of their Health Studies curriculum) throughout Auckland on sexuality, transgender and intersex issues. I ask Penniket what she would recommend for health and support services for intersex people:

\footnotetext{
"Maybe 95 percent of people would feel more comfortable if health professionals saw physical sex as a continuum, and not as a binary, and not even as three options. Like, I don't just think they should think of intersex as a new category. I think they should see diversity in bodies. That would help with things like body image, because everybody has a different body size, and it would help with genitals because even if you take a group of
}

\footnotetext{
${ }^{73}$ Rainbow Youth also states that while "queer" is a "reclaimed word that represents sexuality and gender diversity" which include transgender and intersex identities, and "everyone in between and not sure", "it is also appreciated that it is not the preferred term for everybody" (Rainbow Youth, 2010).
} 
people who identify as 'woman', and people who have female anatomy, their genitals are going to look different."

(Penniket, 2010, interview).

Penniket has worked with health and community professionals such as social workers, and has facilitated sessions at universities with nursing and social work students (ibid.). During a session Penniket will discuss topics such as sexual orientation, gender identity and intersexuality, as well as gender identity and transitioning which includes transgender issues (ibid.). She will also discuss discrimination such as homophobia and transphobia and will give examples of how this occurs (ibid.). Penniket believes that the medical curriculum needs to cover genital diversity, particularly on topics covering genitals (ibid.). She also recommends that guest speakers should be invited to talk to students about their personal experiences such as being transgendered, gay or intersex, as discussion of a topic is enhanced by a "real-life perspective" (ibid.). Penniket often endeavours to invite people to talk at sessions and workshops she facilitates as, she says, "that works really well" (ibid.). She comments on societal attitudes towards sexuality in relation to gender identity:

'Because we're brought up to think 'man, woman, penis, vagina - done'. Whereas when you're taking someone who is just identifying their gender for how they feel, then when they're attracted to someone else it becomes a multiplicity of opportunities of how those people identify... and what does that mean for sexuality. Because if you've got an FtM female-to-male transperson, hooking up with another guy, that's two guys - so they're gay, because they're two guys. But some people get really confused, because what if one of those guys - the transguy, still has a vagina? Then they're straight - some people will think that."

(Penniket, 2010, interview).

Penniket's professional development-type workshops are similar to the workshops she facilitates in secondary schools, which includes drawing and talking about a "gender diagram":

“...it has sex on one line, gender on another - male, intersex, female. Then down the bottom under gender - male, intergendered, and female. Then I draw boxes around male/male, and boxes around female/female - connecting those, and then show that all this stuff in the middle could come under the umbrella 'transgender'. Then I explain the continuum between male, female and intersex. I explain those three, and explain how there's variations, and then for gender I draw another continuum line between male, female and intergendered."

(Penniket, 2010, interview). 
Tom Hamilton, Executive Director of Rainbow Youth, is a female-to-male transperson himself who commends the work of photographer Rebecca Swan (in chapter 2) in relation to diverse communities:

“...what Rebecca's work symbolises for me is the importance of visibility, and that we are bodies - we do things, we have relationships, we have good relationships, we enjoy our bodies and we like the way we are. So I'm a huge advocate for the body being seen as not only a discourse but more holistically, and us having a greater understanding of... basically that genitalia does not mark us as a gender identity."

(Hamilton, 2010, interview).

I asked Hamilton his thoughts about including Swan's Assume Nothing project in medical and nursing education in New Zealand:

\begin{abstract}
"Oh yes. When it comes to medical education, the thing about Rebecca Swan's work that is important is not the vision, it's about the relationships she has with each of the portraits. That work, if people follow it, and those people who've been in those portraits will talk, and their lives are very different... You know, it doesn't homogenise us, it shows our diversity. And that's the part about Rebecca's work which I think is really incredible, because her images give that voice, they show the diversity of our community. We're either going to be a man or a woman - there's no in-between. So things like Rebecca's work show us the inbetweens really well."
\end{abstract}

(Hamilton, 2010, interview).

Penniket's and Hamilton's comments not only highlight the existence of diverse communities in New Zealand, but that parts of society can be accepting of bodies and sexualities that differ from male/female binary, heterosexual norms. While Barnes and Cheetham (1999, pp. 980-981) advise female sex assignment and rearing on the finding of a vaginal cavity via a genitogram (which suggests an assumption that the individual will become a heterosexual woman), Penniket notes that some transmen have vaginas and have sex with men as gay men. Furthermore, Penniket's observation about male identification offers a different perspective to medical rationales about male sex assignment based on phallic growth, such as the recommendation of a trial of testosterone administration for PAIS individuals (Forest, 2001, p. 1995).

Hamilton also offers a differing perspective to medical rationale for sex assignment, with regard to David A Diamond's view (in chapter 5) that testosterone administration has produced "disappointing” results for PAIS individuals (Diamond, 2007, p. 3825). The word "disappointing" suggests that PAIS individuals with small phalluses may be unhappy and unfortunate, but Hamilton asserts that people with diverse bodies beyond 
typically male and female forms are happy with their bodies and in their relationships. I would therefore suggest that Swan's Assume Nothing project (and Kirsty MacDonald's documentary film $(2008)^{74}$ of the same title, which contains interviews with Swan's subjects) would offer alternative perspectives to medical teaching about sex assignment - and indeed societal constructions of masculinity and femininity.

\section{Georgina Beyer - human rights and gender identity in New Zealand}

Georgina Beyer, former Member of Parliament for Wairarapa (1999-2005), made history in 1995 when she was elected as the world's first transgender mayor (of rural town Carterton), then as the world's first elected transgender member of parliament in 1999. In 2004 she introduced the Human Rights (Gender Identity) Amendment Bill in Parliament, which provided for gender identity to be included in section 21 of the Human Rights Act 1993 as a prohibited ground of discrimination (Parliament, 2010). The Bill's definition not only included transgender people but intersex people "who are assigned a gender with which they later do not identify" (ibid.). In 2006 Beyer withdrew the Bill after a legal opinion from the acting Solicitor-General suggested that "transgender people were already protected under the Human Rights Act" (NZ Herald, 2006). However, Beyer was not satisfied with this statement and asked the then Attorney General, Dr Michael Cullen, to "also confirm that this is how he saw it" (G. Beyer, personal communication, 2 September 2010).

At Beyer's request, the case was then formally agreed by both the acting SolicitorGeneral and Attorney General in writing and signed off by them, and with leave of the House she tabled the document in Parliament (ibid.). Therefore, as "a matter of the public record" the Gender Identity Bill is in fact included in section 21 of the Human Rights Act 1993, "although not explicitly mentioned" (ibid.). I ask Beyer about her reasons and motives for introducing the Bill:

\footnotetext{
"It was an opportunity for the Government to introduce something about gender identity which was not mentioned in section 21 . In the amendment, that's what it sought to do. If the matter of gender identity came to court then legal redress could be sought in terms of discrimination. For example, how do intersex people say, 'I believe my rights have been abused.' I just wanted recognition to be inclusive of - but not exclusive to - trans, crossdressers, intersex and so on. Given societal constructs we are imprisoned in a box.
}

\footnotetext{
${ }^{74}$ Source: http://www.rebeccaswan.com/assumenothing.htm
} 
"I was told that the Labour caucus would be making a conscious vote. It all started in 2005, Destiny Church... the social, political and national climate didn't help. With regard to funding for assignment surgery, intersex people probably have little hope - there are only four surgeries per year with only $\$ 70,000$ in funding!"

(Beyer, 2010, interview).

I then ask Beyer about the type of support that should be available to parents of intersex children, particularly as some may be stressed about their children's intersex diagnoses:

“Love your child, don't care what others think! Love your child as a human being. It's a crime against humanity to inhibit human potential. Parents should never hide anything about their child - the greatest hurt is hiding things. Clinicians think and analyse too much [regarding gender identity disorder and gender dysphoria] - how are we meant to cope in society! There are no rights now for people of sexual minorities - which can change at the whim of the Government. Our lives are still being kicked around - we've improved in awareness, to be addressed in the public health system - I demand equality. ...

"There's a whole lot of apportioning of guilt and blame, partly down to the medical profession - fitting into society: 'Not normal, unusual.' Maybe in the 1950 s to $1960 \mathrm{~s}$ doctors did know best, but they need to wake up to $2010 . . . "$

(Beyer, 2010, interview).

Beyer also believes that parents should be informed about choices and options, particularly if an intersex diagnosis is "a bolt out of the blue for them" (ibid.). While parents should be supported, Beyer further asserts that they should be given information that is "trustworthy and reliable", as well as information about "myths" in terms of human rights:

"The child should be honestly informed of their origins. So when they begin to understand their gender, don't stop them but protect them from danger - especially between the ages of five and 10. It's only when the child hits puberty - gender and sexuality is not an issue till then. ...

"If parents make an issue it will become an issue. Talk with the child... pay no attention to social disapproval. The child should be celebrated for their difference - not degenerated, and should not be made to wear guilt. Parents should not be torn apart by some stupid social construct."

(Beyer, 2010, interview).

With regard to medical education in New Zealand about intersexuality, Beyer believes that the curriculum is not well-informed about psychological matters and that it relies on the Johns Hopkins model:

"They need to talk to the community and people living now. They need to offer the person
and families a pathway through a particular situation - to counselling or support services
and to particular needs, not everyone's the same. They need to realise they're normal
human beings who have a particular variation, who have barriers because of societal
attitudes. ... The psychiatric and medical professions need to take intersex and trans issues 
seriously - it's a cause of suicides, a contributing factor for someone to decide to live or die. $\ldots$

"There's a lovely Maori saying: it is people, it is people, it is people [he tangata, he tangata, he tangata]. It is the person - before superficialities. Why does something between the legs render you unintelligent?"

(Beyer, 2010, interview).

Beyer's perspective offers a way out (in terms of empowerment) for parents who may be feeling upset, isolated and silenced by judgemental attitudes, which Jacqui's mother experienced (in chapter 11) and which Hofman commented on (in chapter 9). While New Zealand's connectedness can, I suggest, cause people to become more silenced because of a fear of being found out, and while some parents may wish to protect their children from teasing, Beyer offers empowerment with her assertion that human potential should not be inhibited because of judgemental attitudes. She further appears to uphold the rights of children with her assertion that their variation of sexual anatomy should be openly discussed instead of being withheld from them. Indeed, Beyer's comment about guilt and blame is relevant to psychological issues in terms of support an aspect that Jacqui (in chapter 11) commented on.

\section{Conclusions}

This chapter has highlighted the advantages of involving the community more extensively in medical and nursing education in New Zealand - that is, including the voices of people from "the margins" amongst the elite (Spivak, 1988, p. 25). As Beyer remarks, New Zealand appears to rely more on internationally-renowned medical institutions such as Johns Hopkins instead of community ("subaltern") opinions (ibid.). While medical institutions may be leaders of knowledge about human anatomy and causes of specific conditions, I would assert that intersex people and others in the community are the leading authorities on "real life" experiences (Penniket, 2010, interview). With regard to this and McEwan's perspective that medicine is a philosophy, New Zealand's medical curriculum should, I argue, include study on ethics and "big questions": whether ambiguous genitalia can negatively affect an individual's quality of life, or whether one can correctly predict a newborn baby's future sexuality and gender identity. This is with regard to Skinner's remark about his paediatric surgery training, in which he would welcome more teaching on intersex and gender issues. 
With regard to community involvement, Hofman's acknowledgement of gender fluidity (as discussed in chapter 9) suggests that Swan's Assume Nothing project could be compatible with medical curricula. McEwan's perspective that "there is no single answer" (McEwan, 2010, interview), and the midwifery programme's intersexuality component (where groups of students work with different scenarios and then present their ideas), would also offer an alternative approach to classes of medical students. This approach, I suggest, would enable medical students as future clinicians to consider the most appropriate way to manage individuals with differing health, gender and social needs. In order to achieve better outcomes, I argue that medical, midwifery and nursing institutions, and community/support organisations, should all work together and share ideas in teaching about intersexuality's wide-ranging anatomical and social aspects. 


\section{Chapter 13: \\ Conclusions and recommendations}

At the beginning of my research, I thought that findings from my interviews with intersex New Zealanders would correspond to already-published accounts by intersex people in New Zealand and other countries. At times, however, narratives contradicted published accounts. The first section in this chapter outlines my reflections on my fieldwork, its limitations and what could have been done differently.

I will discuss what my thesis brings to the body of knowledge - particularly with regard to the issue of children's human rights. I will then provide recommendations based on my findings, in the hope that this may optimise outcomes for intersex New Zealanders and their families. Finally, I suggest further research that should be undertaken to further our knowledge of intersexuality.

\section{Reflections on my research}

When I embarked on my research I read extensively about intersex people's experiences, and watched documentaries and current affairs television reports on intersex issues. Apart from Mani Mitchell, publicly intersex people whom I read about or saw on film or television documentaries were from overseas. Though intersex New Zealanders' experiences have been published in MacKenzie et al.'s (2009) article and the Human Rights Commission's (2007) report, people's identities are protected by pseudonyms and anonymity. This suggests that New Zealanders with intersex conditions are concerned about their privacy - particularly in a country with a small population.

Difficulties in maintaining confidentiality, due to New Zealand's small population and connectedness, may have been why some intersex people chose not to participate in interviews. Even the option of participants completing written questionnaires anonymously did not return any results. This may have been because of the way questions were phrased, despite my efforts to use appropriate language (see page 128). I may have succeeded in interviewing a greater number of intersex participants (or received completed written questionnaires) had I been an insider - a person with an 
intersex condition or a parent of an intersex child. Some intersex New Zealanders may have considered that, if I was an intersex person or a parent, I could not only empathise but share experiences with them.

One finding from my research was that views towards genital surgeries vary among intersex people, often contrasting with published experiences (in chapter 7). Participants may have been hiding details from me which coloured their narratives (Portelli, 1991, pp. 52-53). If I had an intersex condition, it is possible that there may have been fewer gaps in data collection due to participants feeling more willing to disclose more details to me, as I may have had similar (and possibly negative or traumatic) experiences of hospitals myself. It is also possible that, regardless of whether I was intersexual or not, some intersex people may not have wanted to recall distressing experiences. As discussed previously (page 137), my research's strong medical focus may have dissuaded some intersex people about participating in interviews. Some may even have regarded my research focus as having a prurient aspect.

\section{Medical rationales, health concerns, gender and sexuality}

My findings show that there is a complex relationship between the medical management of intersexuality and people's mental health. While a clinician (page 147) shows that screening for CAH is important for intersex children's physical health, another clinician (page 162) and a counsellor (page 194) emphasise concerns about intersex people's mental health. Bowkett suggests that clinicians who recall intersex children frequently for appointments need to be sensitive to their feelings. Although clinicians may be concerned about a child's physical health, frequent hospital visits may be detrimental to the child's mental health in terms of feeling stigmatised. Indeed, intersex people's narratives (in chapter 7) show that frequent clinical visits during childhood were a dehumanising experience. Natalie suggests that medical rationales should focus less on physical procedures (such as genital surgery) and more on an intersex person's mental well-being. But at the same time she asserts that intersex people's anatomical differences can make them more susceptible to mental illnesses such as depression, aggravated by peer rejection and social isolation. This emphasises the importance of support discussed later in this chapter. 
While Hillman (in SFHRC, 2004) and Holmes (1998, p. 221) assert that imposing binary sex classification may be detrimental to intersex people's mental health, my findings show that some parents, health professionals and even some intersex people (page 188) feel otherwise. Medical rationales for genital surgeries appear to be influenced by parents' assumptions about gender and sex anatomy (page 154): the assumption that children are either boys or girls and that their genitalia (penis or vagina) confirms this. However, it is understandable that parents may feel distressed when their sense of normality (the feeling of "is our child OK?") has been disrupted (see McEwan, page 162). One parent, who felt stressed when her newborn baby's sex was questioned (page 168), was also concerned that her child's enlarged clitoris would provoke teasing (page 157).

I found that medical rationale for genital surgeries is sometimes influenced by parents' concerns about their children's mental well-being. Alternatively, some clinicians appear to convey to parents that ambiguous genitalia are "unfortunate" conditions for children (pages 157-158). Some clinicians even appear to display "patriarchal misogyny" (Holmes, 1995) towards female-assigned children by pressuring their parents to consent to genital surgeries (page 154). I argue that such pressure from people in positions of power can be detrimental to parents' mental well-being. This again emphasises the importance of support, as well as the issue of acceptance which is discussed later in this chapter.

Aside from mental health issues, another finding about genital surgery raises the issues of children's human rights and trauma. Sarah pointed out (pages 155-156) that a consequence of undergoing vaginal surgery at a young age is that it needs subsequent dilation work to prevent the vagina from narrowing. In particular, her comment that a parent "can't" dilate an infant's vagina raises the issue of sexual abuse. A baby would not only be very distressed by this, but a baby also cannot consent to such an invasive action which could be regarded as a gross breach of children's rights. This is what happened in the "baby smears" case at National Women's Hospital from 1963 to 1965 when, at Herbert Green's instruction, vaginal smears were taken from newborn girls in order to compare cells from babies' cervices with women's (Coney, 1988, p. 209). Auckland clinician Diana Nash remarked that the smears would have been "painful" and 
"quite traumatic" as "[1]ittle babies are extremely sensitive" (ibid., p. 210). Rae Julian, the then Human Rights Commissioner, was not only "shocked and appalled" by the case but questioned whether the babies' hymens had been broken (ibid., p. 210).

It should also be considered that a child, when older, may not even want a vagina (see pages 113-114, 149). Even an older child may not use dilators as, at a young age, they could understandably feel emotionally uncomfortable if ordered by parents to insert a dilator in their vagina - despite parents' persuasions that "the doctor says you have to". I found Sarah's assertion (pages 155-156) compelling, that young people need to reach an age when they feel comfortable about their bodies - that they are ready to deal with sexual issues before using dilators. I therefore conclude that, when considering sensitive issues such as genitalia and future sexuality, it seems more appropriate to leave decisions about surgical procedures with intersex people themselves when they reach an age to given informed consent, instead of their parents.

\section{Narrators' understandings about clinical procedures and gender}

The medical management of intersexuality raises important but complex ethical questions. Creighton et al. (2004, p. 45) show that surgeries have implications for children's later lives as adults, such as possible loss of sensation: this raises the issue of children's human rights. However, my research findings reveal a variety of perspectives about surgery. While the implications of surgery (such as loss of sexual sensation and scarring) also raise the issue of informed consent, one intersex participant asserts that genital surgeries should occur before children start school (page 188). Another participant (page 198) felt that her parents made the best decision when surgery was performed before she could remember. These narratives cloud the issue of informed consent and raise an ethical question: should parents consent to their children's surgical procedures if their children are too young to talk? These narratives do, however, confirm that there is no general best practice plan to suit everyone.

The issue of informed consent becomes more complex from another finding (page 159): stopping genital surgeries in New Zealand may profoundly affect some families in 
which parents are distressed by their children's genital ambiguity. However, one should consider that, while parents may be distressed, the children themselves may not be - especially when they get older and become sexually active. Parents therefore need information and easily-accessible support (a telephone call to another parent, for example). Indeed, Mitchell (page 160) quotes a surgeon's advice that one should not remove something from children that they may want later.

Rogena (pages 156-157) questions the rationale for hir two surgeries for hypospadias, particularly as the urethral opening's original position was of no importance to hir. Rogena's experience not only shows that parents have a duty to consider the risks of genital surgery, such as diminished fertility (see page 193), but also whether rearing as male or female (according to one's assigned sex) is necessary. Rogena's desire not to identify as male or female (page 199) is consistent with Harper's research findings, in which one intersex narrator, Sal (in Harper, 2007, p. 100), asserts that there is little point in male or female sex assignment if surgery diminishes sexual sensation. Nevertheless, three intersex participants (pages 197-198) asserted that they are happy with identifying and calling themselves female.

\section{Support and acceptance in New Zealand}

My findings show that support is particularly crucial during an intersex person's childhood and adolescence. Jacqui's narrative (page 188) emphasises that support is particularly important during teenage when one may feel self-conscious amongst one's peers. Indeed, Anonymous 3 (page 191) recalled positive experiences from knowing another child with $\mathrm{CAH}-$ a close friend with whom she shared experiences while growing up.

My findings also show that support is just as crucial to an intersex person's family members, particularly as they may be completely unfamiliar with intersexuality (pages 169-170). Hofman's comment (page 164) that some families are reluctant to discuss their children's intersex conditions, because of the fear of "being different", confirms that support is badly needed by some families. I argue that support should not only be more easily available but less paternalistic, in that it does not cause people to feel 
stigmatised (see Jacqui, page 190). Easily-accessible support (for example, telephoning a registered nurse or counsellor) is particularly important in New Zealand with its greater connectedness which, I suggest, compels families to keep silent about matters which they may fear others may gossip about. Indeed, a support group (which was not available at the time) may have alleviated the "struggle" which Jacqui's mother experienced from other mothers' judgemental attitudes - some whom she considered to be good friends (page 189). Furthermore, keeping silent about their children's condition no doubt compounds the stress and worry which some families may be experiencing, and in turn causes their children to feel shame. This is where the internet can help families: support organisation websites which can provide extensive information in the privacy of families' own homes - particularly useful in a small populated country like New Zealand.

While some parts of New Zealand society are judgemental towards difference, which causes some families to keep silent about their children's conditions, my findings show that GLBTI communities in New Zealand society accept and celebrate sexual and gender difference. Organisations such as Rainbow Youth and the Human Rights Commission, intersex activists such as Mani Mitchell, and artists such as Rebecca Swan, provide advocacy, empowerment and visibility to intersex New Zealanders and their families.

\section{My findings, issues and theoretical positions}

Three key issues emerge from my findings: societal power structures (and resistance to these), children's and women's rights, and medical power (specifically power relations between clinicians and parents of intersex children).

The issue of societal power structures arises from a parent's narratives about rural New Zealand social settings, which show that the smallness of rural communities can assist in maintaining societal power structures. Bronwyn's narratives (pages 143-145) suggest that pressures to conform to rigid gender binary categories are particularly strong in rural New Zealand settings where one's past always remains amongst a close-knit community. Indeed, Bronwyn advises that parents should remain strong against 
pressure to answer society's "Is it a boy or a girl?" question when a newborn child's sex classification is questioned, as judgemental attitudes may come back to haunt that child at a vulnerable age. Bronwyn's narratives also illustrate how societal constructions (albeit assumptions) about normality can rigidly maintain male and female categories. One such assumption is that a person's birth classification as male or female remains rigid throughout their lifetime. This issue also emerges from judgemental (see page 189) and even vindictive attitudes (see page 144), which pressures some parents to remain silent about their children's intersex conditions (see page 163).

However, other findings reveal resistance to societal power structures - namely constructions about "normal" male/female binary classifications. This is illustrated by Jo's narratives, such as giving children age-appropriate information (page 158) and when she told her daughter that difference is acceptable (page 164). Medical power also arises from Jo's narrative about a videotape on virilised genitalia (pages 157-158), which reinforces Chase's (1998, p. 212) argument about medical constructions of intersexuality as an "unfortunate" condition that needs to be surgically fixed. Indeed, when her endocrinologist suggested genital surgery for her daughter (page 158), Jo challenged medical power and constructions about intersex anatomy when she suggested that her daughter's enlarged clitoris may benefit her future sexual relationships.

Resistance to societal power structures also emerges strongly from the work of a community/support organisation. This is illustrated by the narratives of two Rainbow Youth representatives. Penniket's illustration of a transman with a vagina and a man with a penis having sex (page 216) can be regarded as challenging traditional notions of (hetero)sexuality, which bears similarities with theorising about the construction of individuals (see Davies \& Gannon, 2005, p. 218). Indeed, Penniket's narrative about some people's confusion (page 217) illustrates social constructions about men based on anatomy - the notion that men do not have vaginas. Such social constructions relate to queer theorising about genitals and sexuality - the notion that two people having penilevaginal intercourse are heterosexual instead of gay, because of the assumption that the transman's gender must correspond to his genitals (see Nataf, 1996, p. 18). 
The issue of medical power is highlighted in a nurse's narratives about her interactions with parents of intersex children - and clinicians who pressure parents to consent to genital surgeries on their female-assigned children (page 154). This in turn raises the issue of children's rights - the right to full informed consent. Furthermore, when children get older, the issue of women's rights (especially to their own sexuality) arises from the consequences of their female assignment - the notion that girls should not have large clitorises. The latter issue relates to feminist arguments about sexual inequity between men and women: the patriarchal notion that a woman with sexual desires is deviant - a "slut" (Matthews, 1984, p. 122). Deborah's narratives about some clinicians who pressure parents can be regarded as illustrative of "patriarchal misogyny" (Holmes, 1995), which relates to theorising about sexual difference. Such pressure on parents because of their children's assignment as female - reinforces Holmes' (1995) argument about "patriarchal misogyny" towards girls with enlarged clitorises. This is also similar to Ehrenreich's and English's (1978, pp. 47, 50) feminist argument that 19th century clinicians pathologised enlarged clitorises - the patriarchal notion that, unlike men, women were not supposed to be sexual.

The issue of medical power also arises from parents' narratives about their interactions with clinicians - some of whom appeared to be conscious of their supposed status as “expert” (Coney, 1988, p. 246). This is illustrated by Sarah's narrative (page 173) about her reluctance to ask questions about her son's condition, Bronwyn's and Murray's narratives (pages 174-175) about their clinician appearing arrogant and patronising, and Anonymous 2's narratives (pages 179-180) about being “ordered" to leave a consulting room her daughter was in. These narratives not only reinforce feminist arguments about medical power and hierarchy, but also people's rights to full information (Coney, 2009, p. 69).

However, societal power structures - the pressure to be "normal" - can shift power relations between clinicians and parents of intersex children. My findings show that some parents and even some intersex people themselves can influence clinicians to perform genital surgeries on intersex children - particularly before they begin school (page 188). Some parents wish to protect their children from teasing and bullying (see page 157) while, with regard to debates about informed consent and delaying surgery, 
one intersex person raised concerns about peer issues during teenage years. This reinforces a conclusion that the medical management of intersexuality is complex and difficult, and that there is no single best solution to suit everyone.

\section{Recommendations}

My first and immediate recommendation is that a child's physical health must take top priority. If the baby has the most serious salt-wasting form of $\mathrm{CAH}$, the baby may die within a few days. Therefore, when a newborn baby shows symptoms of a possible intersex condition - the most obvious being ambiguous genitalia - clinicians should immediately establish whether the baby has lipoid CAH. If tests confirm that the baby does not have lipoid $\mathrm{CAH}$, clinicians should nevertheless undertake a diagnosis for a particular intersex condition so that appropriate medical care (prescribed medication for less serious CAH types, for example) can be established to meet the child's health needs.

While any tests for health concerns are being undertaken, support for the child's family should be a priority too. My findings show that a newborn baby's "uncertain" classification as a son or daughter is likely to be concerning for parents, and without a doubt the child's parents may be very worried and stressed about their newborn baby's health. I recommend that a health professional (such as a registered nurse) with knowledge about intersex conditions inform them about support groups and provide a copy of Leigh McCarthy's easy-to-understand pamphlet (pages 214-215). As my findings show, the mere presence of a nurse can make families feel supported. Even a simple task such as sitting in silence with a family and expressing empathy, which registered nurse Sheryl does (page 146), can be a great comfort to them. At the same time the nurse should try to answer any questions the family may have, but not overwhelm them with too much information at once - particularly information with medical jargon which some parents may not understand (see page 168).

Once the child's diagnosis has been confirmed, clinicians should have detailed discussions with the parents about their child's options. However, clinicians should never pressure parents into consenting to procedures (Deborah, page 154) which their 
child, when old enough to consent, may not agree to. Support organisations can also play a role in providing extensive information parents about their child's options, such as the implications of genital surgery (see pages 155-156, 158-160). This is not only informing parents about medical procedures and their risks, but about their child's own gender identity - and that this may change as the child gets older.

With regard to support, I recommend that medical school teaching not only include information about risks of surgery, such as loss of sexual sensation, but its emotional implications - particularly with genital surgery. Jacqui's narratives indeed raised this issue: she did not feel ready to become sexually active when she underwent vaginal surgery in her teens (page 186), and that surgery was performed at an age when she felt particularly vulnerable amongst her peers (page 188). My research suggests that medical teaching ought to also include case studies of intersex people who have not undergone surgeries, such as Viloria who has always been happy with her body (Viloria, 2011). Most importantly, when considering people's first hand experiences (in chapter 7), medical training should raise questions (akin to philosophical debates) - for example, whether surgery to feminise the appearance of genitals is necessary.

A key recommendation arising from clinicians' narratives (Hofman, page 152; Beasley, pages 152-153; McEwan, page 163) is that New Zealand should establish a multidisciplinary team to focus on intersex conditions. This recommendation also arises from intersex participants' narratives (pages 186, 190-191) about the implications of New Zealand's small population in relation to Australia which, because of its larger population, has more experience of intersex issues which includes a multi-disciplinary team approach. The team should not only comprise specialist clinicians, registered nurses, social workers (Hofman, page 152) and mental health professionals (Natalie, page 194), but representatives from community/support organisations and cultural communities such as Maori (takatāpui). My research suggests that differing cultural perspectives of gender identity and sexuality (as discussed in chapter 2) could contribute to broadening the traditional Western medical model of male/female binary sex classification, particularly with regard to supporting instead of merely managing an individual. 
My findings also led me to the view that, while New Zealand and Australia ought to adopt a team approach, they should also focus on an intersex person's needs and wishes (Natalie, page 194) rather than a particular condition. As already discussed, I noticed differences in views between some of my participants and published accounts. While Jacqui (page 188) feels that surgery should be performed early in a child's life particularly to avoid peer issues during teenage, and Anonymous 3 (page 198) felt that her parents made the right decision for her first surgery, others such as Rogena (pages 157,193 ) and Briffa (in chapter 7) dispute the rationale for their surgeries which they did not agree to - especially with regard to their own gender identities. My research thus shows that undertaking a specific medical procedure, in relation to a particular intersex condition, may not be the best outcome for everyone with that condition. I therefore recommend that medical teaching and resources (such as textbooks) should include information and discussion about case studies - and what worked and did not work for each individual. This information could be obtained by medical institutions and publishers approaching intersex support organisations.

Like the midwifery programme (page 212), medical students could then work with scenarios with ISNA resources, for example, and discuss the most suitable clinical management plan to suit an individual's needs and wishes. Facilitators of group discussions should include intersex people as well as clinicians. This way, future clinicians would hear first hand accounts of what worked and did not work for intersex people themselves. At the same time, future clinicians should also hear about intersex people's past interactions with clinicians: aspects of clinicians' behaviour and language which made intersex people feel shameful and embarrassed, as well as aspects which made intersex people feel supported.

I also recommend more publicity and media initiatives about positive aspects of variations of sexual anatomy. This is not only to inform individuals and their families, but in the hope that individuals may accept (and feel good) about themselves and their bodies - that everyone's anatomy, like hair and skin colour, is different. Such initiatives could be based on Swan's Assume Nothing photographic project which received much publicity when it was exhibited throughout New Zealand during 2008, and in turn informed the general public that gender can be more than dichotomous. Further 
initiatives, in the form of a publicity campaign, could be undertaken by national community/support organisations such as Rainbow Youth in collaboration with health organisations such as district health boards (DHBs). Resources produced from such a campaign could be based on positive published accounts by intersex people such as Hida Viloria (2011), whose intersex anatomy has not undergone medical intervention. Akin to McCarthy's (2009) “reassuring” pamphlet for parents, more media such as children's books - stories about children with intersex conditions leading happy, adventurous lives - may inform parents and the wider community that intersexuality is not an "unfortunate" condition that should be hidden and denied.

\section{Future research}

As this thesis presents findings from only five intersex New Zealanders, I welcome future research to be undertaken in New Zealand by intersex people themselves. Unlike myself, they would be insiders to intersex communities and experiences, and may be more successful than I have been in finding a greater number of intersex participants. Furthermore, as intersex participants may feel more comfortable being interviewed by another intersex person, the latter may be more successful in obtaining detailed findings on the following issues which may be regarded as sensitive research topics.

While sexual sensation and teenage sexuality may be regarded as sensitive topics, comments from participants in this thesis such as Sarah, Lisa and Jacqui strongly suggest that further research needs to be undertaken on the outcomes of feminising (particularly vaginoplasty) surgery. While some may assert that genital surgery should be performed at a young age, further research needs to be undertaken on its consequences when individuals become sexually active, which Sarah highlighted (page 160).

In relation to vaginoplasty procedures, Sarah and Jacqui's comments also suggest that research needs to be undertaken on both the physical and psychological implications of vaginal dilation. Sarah's narrative about intersex people living in isolated areas in New Zealand, who may need advice on how to use dilators correctly (page 187), shows that this can be embarrassing for some intersex people. Indeed, a person's genitals (and 
possible genital surgeries) are understandably very personal and private matters. Thus research should include discussion of strategies on how to overcome these barriers.

Furthermore, research on emotional aspects of medical procedures could benefit from addressing the implications of New Zealand's small population, in terms of confidentiality and access to support, and comparisons could be made with countries such as the USA and Canada which have larger populations. Comparisons could also be made with other countries such as Denmark and Norway which, like New Zealand, have small populations and therefore smaller numbers of intersex diagnoses. In particular, comparisons could be made of intersex people's support networks in these countries, and whether intersex people in Denmark and Norway, for example, share similar concerns with New Zealanders about confidentiality and judgemental attitudes from others.

Acceptance of gender fluidity amongst takatāpui communities in New Zealand suggests that research should be also undertaken on indigenous perspectives on intersexuality. I argue that cultural, advocacy and community/support organisations working together with medical, midwifery and nursing professionals could enable a shift in thinking: from merely managing a condition to supporting an intersex New Zealander's own wishes and needs.

\section{Finally...}

While some parts of New Zealand society may be uncomfortable towards bodies with both male and female characteristics, intersex New Zealanders and their families do not have to keep silent - despite New Zealand's small population and connectedness. Other parts of New Zealand society, who accept and celebrate variations of sexual anatomy, can not only help and support intersex New Zealanders and their families, but educate society as a whole - both nationally and internationally. 



\section{List of participants}

Recorded interviews were undertaken with the following participants who are listed in order of their first name. First names with an asterisk (*) indicate a pseudonym as some participants requested, while others requested to remain completely anonymous. Other participants requested that only their first name be used. At the request of some participants I have withheld the locations where our interviews took place. Dates of interviews are listed in the right hand column.

The five participants with intersex conditions were:

Anonymous 3

Woman with congenital adrenal hyperplasia

Jacqui*

Lisa*

Mani Mitchell

Rogena

Woman with congenital adrenal hyperplasia

Woman with congenital adrenal hyperplasia

Executive Director, Intersex Trust Aotearoa New Zealand (ITANZ), Wellington

Intersex person and postgraduate student
20 November 2010

7 December 2010

27 September and 6 December 2010

7 April 2010

23 May 2011

The other participants were:

Anonymous 1

Mother of a primary school-aged child

28 September 2010 with congenital adrenal hyperplasia

Anonymous 2

Mother of an adult daughter with congenital adrenal hyperplasia

Bronwyn*

Wife of Murray* (whom I interviewed with Bronwyn) and mother of two adult daughters with congenital adrenal hyperplasia

Mr Chris McEwan Plastic surgeon and Adviser to Ministry of Health, Hamilton

Deborah*

Registered nurse
8 June 2010

20 November 2010

6 December 2010

15 February 2011 
Georgina Beyer

Jeanie

Jo

Leigh McCarthy

Murray*

Natalie

Priscilla Penniket

Sarah*

Sheryl

Prof Spencer Beasley

Head of Paediatric Surgery,

Christchurch School of Medicine,

Christchurch

Tom Hamilton

Former Member of Parliament for Wairarapa of tertiary institute withheld) child with congenital adrenal hyperplasia City Hospital, Auckland hyperplasia

Education Co-ordinator, Rainbow Youth, Auckland parents of intersex children

Registered nurse
Midwifery Programme Director (name

Mother of an intermediate school-aged

Neonatal nurse specialist, Auckland

Husband of Bronwyn* and father of two adult daughters with congenital adrenal

Transgender woman and counsellor

Director of a support organisation for

Executive Director, Rainbow Youth, Auckland
5 October 2010

5 July 2010

14 August 2010

18 February 2011

6 October 2010

15 February 2011

6 December 2010

19 February 2011

2 June 2010

2 July 2010

5 July 2010
4 August 2010 


\section{Glossary of frequently used terms}

$\alpha$

Dihydrotestosterone (DHT)

DSDs

Fa'afafine

Glans (also known as the glans penis)

\section{GLBTIQ}

Gonad

Herniotomy $(\alpha=$ alpha $)$ the first letter of the Greek alphabet, used medically to classify specific enzymes (e.g. $5 \alpha$-reductase).

( $\beta=$ beta) the second letter of the Greek alphabet, used medically to classify specific enzymes (e.g. 17 $\beta$ hydroxysteroid dehydrogenase).

Carcinoma in situ (CIS) The earliest stage of cancer spread where the tumour is confined to the epithelium (tissue lining the skin and internal organs), in which "surgical removal of the growth should lead to cure" (Oxford, 2003, p. 107).

Dihydrotestosterone (DHT) masculinises a foetus' external genitalia during gestation. A "genetic male" (with a 46,XY chromosome type) with $5 \alpha$-reductase deficiency (5-ARD) will be born with ambiguous genitalia (Wilson, 2004; Grumbach et al., 2003, pp. 952-953).

(DSD $=d$ isorder of sex differentiation) A common medical term that refers to intersex conditions, though it is acknowledged that some do not support this term.

(Samoan $=$ way of the woman $)$ A Samoan cultural identity where some individuals born phenotypically male feel they have the spirit of a woman, yet identify as male - some as gay men who appear feminine. Other fa'afafine may identify and present (dress, hairstyle etc.) as women and even undertake hormone administration. Traditionally in Samoa, in a large family where the children are all boys, the parents will bring up one child in a female gender role or the boy himself may adopt this role which the parents accept.

The acorn-shaped end of the penis covered by the prepuce (foreskin), unless this has been removed by circumcision.

Gay, lesbian, bisexual, transgender, intersex and queer/questioning.

An ovary or testis (Oxford, 2003, p. 292).

Surgical excision of a hernia sac, the first stage of hernia repair (ibid., p. 315). A hernia is when an organ or tissue protrudes out of the cavity where it normally lies (ibid., pp. 314-315). 
Karyotype

Laparotomy

MBChB

Orchidectomy (also

called Orchiectomy)

Perineum

Phenotype

Plunket

Prader stages of virilisation

Progestogen, progestin
Chromosome type (ibid., p. 370). A male karyotype is 46,XY and a female karyotype is 46,XX (ibid., p. 627). Various other karyotypes include Turner's syndrome 45,XO (ibid., p. 712).

A surgical incision into the abdominal cavity to examine abdominal organs (ibid., p. 382).

( $\mathrm{MBChB}=$ Bachelor of Medicine and Bachelor of Surgery $)$ The first qualification that doctors in New Zealand gain before undergoing specialist training.

Surgical removal of the testes (ibid., p. 490).

The region between the urethral opening and the anus.

An individual's observable physical characteristics. A phenotypical male is an individual with "normal male" characteristics.

A common abbreviation of the Royal New Zealand Plunket Society which employs specially-trained nurses who undertake "well child" assessments on children aged from infancy to five years, either at their homes or at Plunket clinics throughout New Zealand. Plunket groups throughout New Zealand offer support to parents and their children (source: www.plunket.org.nz).

The five Prader stages of virilisation fall in between a scale of "normal $\rho$ " and "normal ${ }^{\lambda}$ " genitalia. Mildly virilised female genitalia falls under stage I, Ambiguous genitalia falls under stage III and mildly "undervirilised" male genitalia falls under stage V (P. Hofman, personal communication, 7 May 2007).

A steroid hormone which maintains pregnancy and prevents ovulation (Oxford, 2003, p. 561). Progestin is a synthetic form of progestogen commonly used in oral contraceptives. 


\section{Appendix I: \\ Approval letter from the Multi-region Ethics Committee}

\author{
SHealth \\ and \\ Disability \\ Ethics \\ 1. Committees
}

\author{
Multi-region Ethics Committee \\ Ministry of Health \\ 133 Molesworth Street \\ PO Box 5013 \\ Wellington 6145 \\ Phone (04) 4700655 \\ (04) 4700646 \\ Fax (04) 4962340 \\ Email: multiregion_ethicscommittee@moh.govt.nz
}

30 July 2009

Geraldine Christmas

Wellington 6141

Dear Geraldine

Gender and medicine: Identities and bodies beyond the male/female binary code Lead Investigator: Geraldine Christmas

Victoria University of Wellington

MEC/08/12/153

The above study has been given ethical approval by the Multi-region Ethics Committee.

\section{Approved Documents}

- Information sheet and Consent Form for participants willing to be narrators

- Information Sheet and Consent Form for participants at non-public meetings and informatl discussions

- Consent process if the participant is an intersex person

- Consent process if the pariicipant is a clinician

- Consent form for clinicians

- Email to medical school departments

- Email to clinicians, seeking information

- Email to clinicians who have previously responded

- Email to intersex support organisations

- Oral interview Questionnaire to clinicians

- Oral Interview Questionnaire to intersex people

- Written Questionnaire for intersex people if unable to be interviewed

\section{Accreditation}

The Committee involved in the approval of this study is accredited by the Health Research Council and is constituted and operates in accordance with the Operational Standard for Ethics Committees, April 2006.

\section{Progress Reports}

The study is approved until July 2011. The Committee will review the approved application annually and notify the Principal Investigator if it withdraws approval. It is the Principal Investigator's responsibility to forward a progress report covering all sites prior to ethical review of the project in 30 July 2010. The report form is available at http://www.ethicscommittees.health.govt.nz. Please note that failure to provide a progress report may result in the withdrawal of ethical approval. A final report is also required at the conclusion of the study. 
Theorising "boy or girl” binary classifications, intersexuality and medical practice in New Zealand

\section{Amendments}

It is also a condition of approval that the Committee is advised of any adverse events, if the siudy does not commence, or the study is altered in any way, including all documentation eg advertisements, letters to prospective participants.

Please quote the above ethics committee reference number in all correspondence.

It should be noted that Ethics Committee approval does not imply any resource commitment or administrative facilitation by any healthcare provider within whose facility the research is to be carried out. Where applicable, authority for this must be obtained separately from the appropriate manager within the organisation.

Yours sincerely

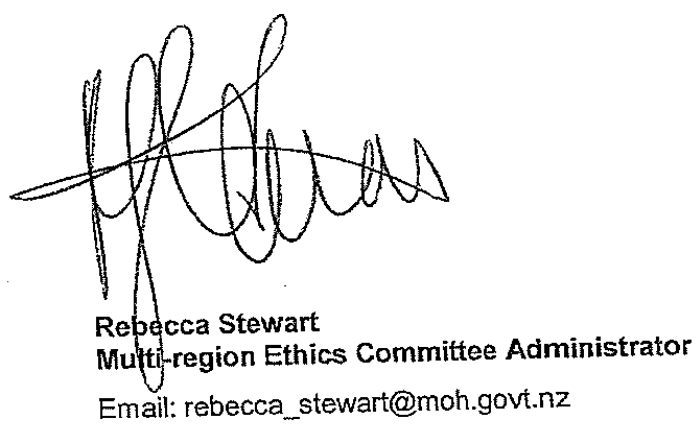




\title{
Appendix II: \\ Information Sheet for participants
}

\author{
VICTORIA UNIVERSITY OF WELLINGTON \\ Te Whare Wananga o te Upoko o te Ika a Mani

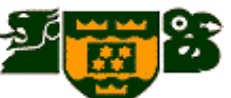 \\ School of Education \\ Te Pūtahitanga o te Mātauranga
}

4 December 2009

\section{Information}

\section{Gender and medicine: identities and bodies beyond the male/female binary code}

You are invited to take part in a study for a $\mathrm{PhD}$ thesis about intersexuality and clinical practice. You can consider whether or not to take part till 30 April 2010. I envisage that this study will be completed by August 2011.

I am being supervised by Dr Alison Laurie and Dr Lesley Hall who can be contacted at:

Dr Alison Laurie: telephone (04) 463 5267, alison.laurie@vuw.ac.nz

Dr Lesley Hall: telephone (04) 463 7467, lesley.hall@vuw.ac.nz

Gender and Women's Studies Department,

Victoria University of Wellington, PO Box 600, Wellington.

\section{Aims of this study}

I am interested in the clinical management of intersexuality from human rights perspectives. This is an under-researched topic, particularly in New Zealand, in which we do not know enough about intersex people's opinions about health services. I hope to talk to clinicians in order to find out about the clinical management of intersexuality and gender matters. Most importantly, I hope to talk to intersex people about their views on health and support services.

\section{Participating in this study}

If you would like to participate in this study, you must:

- be at least 16 years of age; and

- have been born with a variation of sexual anatomy or identify as intersex - or

- be a doctor training or practising in at least one of the following specialties: urology, genitourinary surgery, paediatrics, endocrinology, neonatology, obstetrics or gynaecology.

If you are a health professional, you may wish to contact your professional organisation if you have any queries or concerns regarding your rights as a participant in this study. 


\section{What will happen during the study?}

First, you should complete and sign the Consent Form. Later, you will be interviewed for a recorded "oral history" which will take about one hour. I will then post or e-mail you the transcript (what I've written up) so you can make additions or deletions to it. You may have a friend, colleague, family or whanau support present during the interview, and to help you understand the risks and/or benefits of this study and any other explanation you may require. Also, you do not have to answer all the questions, and you may stop the interview at any time. You are also free to withdraw from the study at any time without giving a reason.

\section{What if I don't want to be interviewed?}

You can choose to complete a written questionnaire and send it back to me anonymously, in a stamped return envelope which I will supply (or by e-mail if you wish).

\section{Confidentiality}

No material which could personally identify you will be used in any reports on this study - unless you clearly request otherwise. No information obtained from you will be published without your written consent. During the study, please be aware that my two supervisors will be checking my unpublished $\mathrm{PhD}$ thesis. No one else will be checking it.

\section{What will happen at the end of this study?}

All participants will be offered a copy of the thesis (a labelled CD-ROM). Research results will also be published in journals, book chapters, my $\mathrm{PhD}$ thesis, and presented at conferences. Please note there may be a delay between information collection and publication.

\section{Can I get support if I want it?}

Absolutely. If you feel you need support or guidance, you can contact the following organisations:

- Intersex Trust Aotearoa New Zealand (ITANZ): telephone (04) 381 2221, contact@ianz.org.nz,www.ianz.org.nz. ITANZ provides information, education and training for organisations and professionals who provide services to intersex people and their families.

- Agender New Zealand Incorporated: telephone (0800) AGENDER or (0800) 243 6337, www.agender.org.nz. Agender New Zealand Inc. is the national support organisation for transgender people, their partners and families, including those questioning their gender identity and intersex people.

- Tīwhanawhana Trust: contact Elizabeth Kerekere, Chair. Tīwhanawhana is a support, advisory and kapa haka group for takatāpui based on tikanga Māori, and is open to anyone who identifies as intersex, trans, fa'afafine, queer, gay, lesbian, bisexual or questioning.

This study has received ethical approval from the Multi-region Ethics Committee which reviews national and multi-regional studies. Their website can be visited at: www.ethicscommittees.health.govt.nz. If you have any queries to the Committee, please quote reference number MEC/08/12/153. 
If you have any questions or concerns about your rights as a participant in this research study, you can contact an independent health and disability advocate on freephone (0800) 555 050, free fax (0800) 27877678 (0800 2 SUPPORT) or e-mail

advocacy@hdc.org.nz. This is a free service provided under the Health and Disability Commissioner Act.

Please feel free to contact me or my supervisors if you have any questions about this study.

Geraldine Christmas

$\mathrm{PhD}$ Candidate

Gender and Women's Studies

Victoria University of Wellington 


\title{
Appendix III: Sample e-mail to support organisations
}

\author{
Subject: Information and opinions from intersex people \\ Dear [name of contact person]
}

My name is Geraldine Christmas and I am a PhD student at Victoria University of Wellington. The topic of my thesis is Gender and medicine: identities and bodies beyond the male/female binary code. My research involves studying the clinical management of intersexuality, which includes analysing current clinical practice from ethical and human rights perspectives (e.g. informed consent). I was wondering if it may be possible to interview people in your organisation, about their views about health and support services available in the community.

I am being supervised by Dr Alison Laurie and Dr Lesley Hall who can be contacted at:

Dr Alison Laurie: telephone (04) 463 5267, alison.laurie@vuw.ac.nz Dr Lesley Hall: telephone (04) 463 7467, lesley.hall@vuw.ac.nz

Gender and Women's Studies Department, Victoria University of Wellington PO Box 600, Wellington, New Zealand.

\begin{abstract}
Alison and Lesley are experienced oral history practitioners and regularly run courses and meetings, which I have been attending as part of my $\mathrm{PhD}$ research. Alison is the Chair of the Lesbian \& Gay Archives of NZ (www.laganz.org.nz), and Lesley is the President of the National Oral History Association of NZ (www.nohanz.org.nz). I am also acutely aware that I will be dealing with issues such as trauma and confidentiality, so my aim is to conduct interviews that allow intersex people to feel safe and empowered. I welcome any suggestions or advice you may have.
\end{abstract}

This study has received ethical approval from the Multi-region Ethics Committee which reviews national and multi-regional studies. Their website can be visited at www.ethicscommittees. health.govt.nz. If you have any queries to the Committee, please quote reference number MEC/08/12/153.

If you would like further information please contact me. Thank you very much for taking the time to read my e-mail.

Yours sincerely

Geraldine Christmas

PhD Candidate

Gender and Women's Studies Dept

Victoria University of Wellington 


\section{Appendix IV: Sample Consent Form for clinicians}

Note: Clinicians would also complete Parts B and C of the sample Consent Form for participants, outlined in the next Appendix.

\section{Consent Form \\ Part A: Gender and medicine: identities and bodies beyond the male/female binary code}

1. I have read and I understand the Information sheet (dated 4 December 2009), about research ("this study") towards a $\mathrm{PhD}$ on the clinical management of intersexuality.

2. I have had the opportunity to discuss this study, and I am satisfied with the answers I have been given. I also know who to contact if I have any questions about this study.

3. I understand that anything I say during this interview/meeting is confidential and will be stored securely.

4. I understand that Geraldine's two supervisors and no one else will be checking her unpublished $\mathrm{PhD}$ thesis

5. I wish to receive a copy of the results - YES / NO

Please be aware that a significant delay may occur between information/data collection and publication of the results.

6. In the written part of Geraldine's thesis, I give permission for my name to be used as follows:
$\square$ full name
first name only
pseudonym

$\square$ no name - I wish to remain completely anonymous

7. In conference papers and published articles written by Geraldine, I give permission for my name to be used as follows:
$\square$ full name
first name only
$\square$ pseudonym

$\square$ no name - I wish to remain completely anonymous

8. I (full name)

hereby consent to Geraldine audio-recording our interview/meeting.

Signature:

Date: 


\section{Appendix V: \\ Sample Consent Form for participants \\ Consent Form}

\section{Part A: Gender and medicine: identities and bodies beyond the male/female binary code}

1. I have read and I understand the information sheet dated 4 December 2009 for volunteers taking part in the study designed to improve healthcare and support services for intersex people. I have had the opportunity to discuss this study. I am satisfied with the answers I have been given.

2. I have had the opportunity to use whanau or family support, a friend or colleague to help me ask questions and understand the study.

3. I understand that taking part in this study is voluntary (my choice) and that I may withdraw from the study at any time, and (if applicable) this will in no way affect my employment.

4. I have had this project explained to me by

5. I understand that my participation in this study is confidential and that no material which could identify me will be used in any reports on this study.

6. I have had time to consider whether to take part.

7. I know who to contact if I have any questions about the study.

8. I understand that Geraldine's two supervisors and no one else will be checking her unpublished $\mathrm{PhD}$ thesis

9. I consent to my interview being audio-recorded.

YES/NO

10. I wish to receive a copy of the results

YES/NO

Please be aware that a significant delay may occur between information/data collection and publication of the results.

11. I (full name)

hereby consent to take part in this study.

Signature:

Date:

Project explained by:

Project role:

Signature:

Date: 


\section{Consent Form \\ Part B: inclusion/exclusion of information}

Name

Location of interview

I understand that Geraldine Christmas is a PhD Candidate at the Gender \& Women's Studies Department, Victoria University of Wellington, and is conducting this oral history as part of her $\mathrm{PhD}$ thesis (GEND690).

Following assessment, I would like the interview recording(s)

$\square$ archived at the Office of the Alexander Turnbull Library, as stated on the attached form

$\square$ returned to me for my own archives

$\square$ erased and destroyed.

In the written part of Geraldine's thesis, I give permission for my name to be used as follows:
$\square$ full name
first name only
$\square$ pseudonym

$\square$ no name - I wish to remain completely anonymous

In the written part of Geraldine's thesis, I give permission for the inclusion of information which can identify me as follows:
full information
modified information
$\square$ fully disguised information

In conference papers and published articles written by Geraldine, I give permission for my name to be used as follows:
$\square$ full name
first name only
pseudonym
$\square$ no name - I wish to remain completely anonymous

In conference papers and published articles written by Geraldine, I give permission for the inclusion of information which can identify me as follows:
full information
modified information
$\square$ fully disguised information

I understand that I may listen to the recording(s) and that I have full control of the interview and may withdraw at any time.

Signed

Date 


\section{Consent Form \\ Part C: Archiving of recorded interview}

Name of Project: Gender and medicine: identities and bodies beyond the male/female binary code (PhD thesis, Victoria University of Wellington)

Name of participant (optional)

Date of interview

Interviewer: $\quad$ Geraldine Christmas, $\mathrm{PhD}$ Candidate

Copyright holder (delete accordingly): Interviewer / Person Interviewed / Other

1. Placement: $I$, the person interviewed, agree that the recording of my interview and accompanying material, prepared for archival purposes, will be held at the Oral History Centre of the Alexander Turnbull Library or returned to me for my own archives.

2. Access: I agree that the recording of my interview and accompanying material may be made available for research purposes, subject to any restrictions in Section 4.

3. Publication: I agree that the recording of my interview and accompanying material, may be quoted or shown in full or part in published work, subject to any restrictions in Section 4.

\section{Availability of Interview}

( ) Full access

( ) Restricted access as specified:

\section{Particular group only}

Not in interviewee's lifetime

Not available for publication, except for Geraldine's $\mathrm{PhD}$ thesis and subsequent conference papers, journal articles and book chapters, without my prior written permission

I require that there be no access to my interview and accompanying material before the release date indicated without my prior permission

Other conditions (specified in Comments below)

Release date:

5. Privacy Act: I understand that this Agreement Form does not affect my rights under the Privacy Act 1993. 


\section{References}

Accord Alliance. (2011). Lawson Wilkins Pediatric Endocrine Society and Pediatric Academic Societies Mini-Course on Disorders of Sex Development (DSD) - When To Tell the Patient? Retrieved from http://www.accordalliance.org/component/content/article/101-general/1179-when-to-tellpatient.html

Achermann, J. C., Ito, M., Ito, M., Hindmarsh, P. C., \& J. L. Jameson (1999). A mutation in the gene encoding steroidogenic factor-1 causes XY sex reversal and adrenal failure in humans. Nature genetics, 22(June), 125-126.

Aspin, C. (2011). Exploring Takatāpui Identity within the Maori Community: Implications for Health and Well-Being. In Q. Driskill, C. Finley, B. J. Gilley \& S. L. Morgensen (Eds.), Queer Indigenous Studies: Critical Interventions in Theory, Politics, and Literature. Tuscon, USA: The University of Arizona Press.

Auckland Women's Health Council. (2012). Abortion. Retrieved from http://www.womenshealthcouncil.org.nz/Features/Womens+Health+Issues/Abortion.html

Barker-Benfield, G. J. (1978). Sexual Surgery in Late-Nineteenth-Century America. In C. Dreifus (Ed.), Seizing Our Bodies: The Politics of Women's Health. New York, USA: Vintage Books.

Barnes, N. D., \& Cheetham, T. D. (1999). Endocrine Disorders. In J. M. Rennie \& N. R. C. Robertson (Eds.), Textbook of Neonatology (3rd Ed.) Edinburgh, UK: Churchill Livingstone.

Bart, P. (1981). Seizing the means of reproduction: an illegal feminist abortion collective - how and why it worked. In H. Roberts (Ed.), Women, health and reproduction. London, UK: Routledge \& Kegan Paul Ltd.

Ben-Chaim, J., Jeffs, R. D, Reiner, W. G., \& Gearhart, J. P. (1996). The Outcome of Patients With Classic Bladder Extrophy in Adult Life. The Journal of Urology, April 155(4), 1251-1252.

Berenbaum, S. A., \& Bailey, J. M. (2003). Effects on Gender Identity of Prenatal Androgens and Genital Appearance: Evidence from Girls with Congenital Adrenal Hyperplasia. The Journal of Clinical Endocrinology \& Metabolism, 88(3), 1102-1106.

Black's Student Medical Dictionary. (2004). London, UK: A \& C Black Publishers Ltd.

Blackless, M., Charuvastra, A., Derryck, A., Fausto-Sterling, A., Lauzanne, K., Lee, E. (2000). How Sexually Dimorphic Are We? Review and Synthesis. American Journal of Human Biology, 12, 151-166.

Bragge, L. (2005). Choosing the right gender. Retrieved from http://www.theage.com.au/ articles/2005/01/31/1107020318710.html

Brodsky, P. L. (2008). The Control of Childbirth. Jefferson, USA: McFarland \& Company, Inc.

Brookes, B. (1991). Annemarie Anon. In C. Macdonald, M. Penfold \& B. Williams (Eds.), The Book of New Zealand Women/Ko Kui Ma Te Kaupapa. Wellington, NZ: Bridget Williams Books Limited.

Brookes, B. (2009). The Making of a Controversy: history, medicine and politics. In J. Manning (Ed.), The Cartwright papers: essays on the cervical cancer inquiry of 1987-88. Wellington, NZ: Bridget Williams Books Ltd.

Browne, K., \& Nash, C. J. (2010). Queer Methods and Methodologies: An Introduction. In K. Browne \& C. J. Nash (Eds), Queer Methods and Methodologies: Intersecting Queer Theories and Social Science Research. Farnham, UK: Ashgate Publishing Limited. 
Bryder, L. (2009). A History of the "Unfortunate Experiment" at National Women's Hospital. Auckland, NZ: Auckland University Press.

Bunkle, P. (1998). Women, Health and Politics: Divisions and connections. In R. Du Plessis \& L. Alice (Eds.), Feminist Thought in Aotearoa/New Zealand. Auckland, NZ: Oxford University Press.

Bunkle, P. (1988). Second Opinion: The Politics of Women's Health in New Zealand. Auckland, NZ: Oxford University Press.

Butler, J. (1990). Gender Trouble: Feminism and the Subversion of Identity (1999 ed.). New York, USA; London, UK: Routledge.

Campion Quirk, C., \& Nilson, J. H. (2001). Hormones and Gene Expression: Basic Principles. In L. J. DeGroot \& J. L. Jameson (Eds.), Endocrinology. Philadephia, USA: W B Saunders Company.

Carryer, J. (1997). The Embodied Experience of Largeness: A Feminist Exploration. In M. De Ras \& V. Grace (Eds.), Bodily Boundaries, Sexualised Genders \& Medical Discourses. Palmerston North, NZ: The Dunmore Press Ltd.

Caslin, S. (2012). Feminism and post-colonialism. Retrieved from http://www.qub.ac.uk/ imperial/keyconcepts/feminism-and-postcolonialism.htm

Chase, C. (1998). Affronting Reason. In D. Atkins (Ed.), Looking Queer: Body Image and Identity in Lesbian, Bisexual, Gay, and Transgender Communities. Binghamton, NY, USA: Harrington Park Press.

Childs, D. (2011). Pregnant Man Thomas Beatie May Stop at 3 Kids. Retrieved from http://abcnews.go.com/blogs/health/2011/10/31/pregnant-man-thomas-beatie-may-stop-at-3-kids/

Cochrane, K. (2010). Natasha Walter: "I believed sexism in our culture would wither away. I was entirely wrong”. Retrieved from http://www.guardian.co.uk/lifeandstyle/2010/jan/25/natashawalter-feminism-sexism-return

Colapinto, J. (2000). As Nature Made Him: The Boy Who Was Raised as a Girl. New York, USA: HarperCollins Publishers Inc.

Coney, S. (1988). The Unfortunate Experiment: the full story behind the inquiry into cervical cancer treatment. Auckland, NZ: Penguin Books (NZ) Ltd.

Coney, S. (2009). Exposing the experiment. In J. Manning (Ed.), The Cartwright papers: essays on the cervical cancer inquiry of 1987-88. Wellington, NZ: Bridget Williams Books Ltd.

Coney, S. (2009). The Unfortunate History. In J. Manning (Ed.), The Cartwright papers: essays on the cervical cancer inquiry of 1987-88. Wellington, NZ: Bridget Williams Books Ltd.

Connell, R. (2009). Gender (2nd ed.). Cambridge, UK \& Malden, MA, USA: Polity Press.

Cox, A. M., Johnson, F., Newitz, A., \& Sandell, J. (1997). Masculinity without Men: Women Reconciling Feminism and Male-Identification. In L Heywood \& J Drake (Eds.), Third wave agenda: being feminist, doing feminism. Minneapolis, USA: University of Minnesota Press.

Cranny-Francis, A., Waring, W., Stavropoulos, P., \& Kirkby, J. (2003). Gender Studies: Terms and Debates. Basingstoke, UK \& New York, USA: Palgrave Macmillan.

Creighton, S. M. (2004, May). Long-term outcome of feminisation surgery: the London experience. BJU International, May 93(3), 45-46.

Crosthwaite, J. (2009). Could It Happen Again? In J. Manning (Ed.), The Cartwright papers: essays on the cervical cancer inquiry of 1987-88. Wellington, NZ: Bridget Williams Books Ltd. 
Cunningham, F. G., Leveno, K. J., Bloom, S. L., Hauth, J. C., Gilstrap III, L., \& Wenstrom, K. D. (Eds.) (2005). Williams Obstetrics (22nd Ed.). USA: McGraw-Hill.

Davies, B. \& Gannon, S. (2005). Feminism/Poststructuralism. In B. Somekh \& C. Lewin (Eds.), Research Methods in the Social Sciences. London, UK: SAGE Publications Ltd.

de María Arana, M. (principal author, HRC staff, 28 April 2005). A Human Rights Investigation into the Medical "Normalisation" of Intersex People. San Francisco, USA: San Francisco Human Rights Commission.

Diamond, D. A. (2007). Sexual Differentiation: Normal and Abnormal. In A. J. Wein (Ed.-in-Ch.), Campbell-Walsh Urology (9th ed.). Philadelphia: Saunders Elsevier.

Diamond, M., \& Sigmundson, H. K. (1997). Management of Intersexuality: Guidelines for Dealing with Persons with Ambiguous Genitalia. Archives of Pediatric and Adolescent Medicine, October(151), 1046-1050.

Dickson-Swift, V., James, E. L., \& Liamputtong, P. (2008). Undertaking Sensitive Research in the Health and Social Sciences: Managing Boundaries, Emotions and Risks. Cambridge, UK: Cambridge University Press. Retrieved from http://assets.cambridge.org/97805217/18233/ excerpt/9780521718233_excerpt.pdf

Dorland's Illustrated Medical Dictionary (31st ed.) (2007). Philadelphia, USA: Saunders.

Drayton, J. (2011). Rebecca Swan, Twins Trans-cendence and art that Assumes Nothing. Art New Zealand, 21 December. Retrieved from http://blog.rebecaswan.com/2011/12/twins-transcendence-and-art-that.html

Dreger, A. D., \& Herndon, A. M. (2009). Progress and Politics in the Intersex Rights Movement: Feminist Theory in Action. GLQ: A Journal of Lesbian and Gay Studies, 15(2), 199-224.

Duncan, S. (1997). Autopsy as Gaze: The Construction of the Hermaphroditic Corpse as a Text of Sexual Difference. In M. De Ras \& V. Grace (Eds.), Bodily Boundaries, Sexualised Genders \& Medical Discourses. Palmerston North, NZ: The Dunmore Press Ltd.

Du Plessis, R. (1994). Gender. In P. Spoonley, D. Pearson \& I. Shirley (Eds.), New Zealand Society: A Sociological Introduction (2nd ed.). Palmerston North, NZ: The Dunmore Press Limited.

Du Plessis, R. (2004). Queer, Queerer, Queerest? Feminisms, Heterosexualities and Queer Theory. In L. Alice \& L. Star (Eds.), Queer in Aotearoa New Zealand. Palmerston North, NZ: Dunmore Press Ltd.

Ehrenreich, B., \& English, D. (1978). Complaints and Disorders: The Sexual Politics of Sickness. In C. Dreifus (Ed.) Seizing Our Bodies: The Politics of Women's Health. New York, USA: Vintage Books.

Erskine, A. (2010). Roman Imperialism. Edinburgh, UK: Edinburgh University Press.

Factor, R., \& Rothblum, E. (2008). Exploring gender identity and community among three groups of transgender individuals in the United States: MTFs, FTMs, and genderqueers. Health Sociology Review, 17(3), 241-259.

Fausto-Sterling, A. (1985). Myths of Gender: Biological Theories About Women and Men. New York, USA: Basic Books, Inc.

Fausto-Sterling, A. (1993). The Five Sexes: Why Male and Female Are Not Enough. The Sciences, March/April, 20-24. 
Fee, E. (1978). Women and Health Care: A Comparison of Theories. In Claudia Dreifus (Ed.) Seizing Our Bodies: The Politics of Women's Health. New York, USA: Vintage Books.

Feinberg, L. (1998). Trans Liberation: Beyond Pink or Blue. Boston, MA, USA: Beacon Press.

Filax, G., Sumara, D., Davis, B., \& Shogan, D. (2005). Queer Theory/Lesbian and Gay Approaches. In B. Somekh \& C Lewin (Eds.), Research Methods in the Social Sciences. London, UK: SAGE Publications Ltd.

Firestone, S. (1970). The Dialectic of Sex: The Case for Feminist Revolution (1971 ed.). New York, USA: Bantam Books, Inc.

Forest, M. G. (2001). Diagnosis and Treatment of Disorders of Sexual Development. In L. J. DeGroot \& J. L. Jameson (Eds.), Endocrinology. Philadelphia, USA: W B Saunders Company.

Fox, M. (2006). Betty Friedan, Who Ignited Cause in 'Feminine Mystique,' [sic] Dies at 85. Retrieved from http://www.nytimes.com/2006/02/05/national/05friedan.html

Fried, B. (1982). Boys will be boys will be boys: The Language of Sex and Gender. In R. Hubbard, M. S. Henifin \& B. Fried (Eds.), Biological Woman - The Convenient Myth: A Collection of Feminist Essays and a Comprehensive Bibliography. Rochester, VT, USA: Schenkman Books, Inc.

Genz, S., \& Brabon, B. A. (2009). Postfeminism: Cultural Texts and Theories. Edinburgh, UK: Edinburgh University Press.

Gilley, B. J. (2011). Two-Spirit Men's Sexual Survivance against the Inequality of Desire. In Q. Driskill, C. Finley, B. J. Gilley \& S. L. Morgensen (Eds.), Queer Indigenous Studies: Critical Interventions in Theory, Politics, and Literature. Tuscon, USA: The University of Arizona Press.

Good News Bible: Today's English Version (1976, 4th ed.). New York, USA: American Bible Society (worldwide: United Bible Societies).

Gould, G. M., \& Pyle, W. L. (1896). Anomalies and Curiosities of Medicine. New York, USA: Bell Publishing Company.

Graham, S. (2006). The secret of my sex. Retrieved from http://www.independent.co.uk/life-style/healthand-families/health-news/the-secret-of-my-sex-411032.html

Green, O. P. (1935). Introduction. In M. Hirschfeld, Women east and west: impressions of a sex expert. London, UK: W. Heinemann (Medical books).

Greer, G. (1970). The Female Eunuch (1999 ed.). London: Flamingo.

Greer, G. (1999). The Whole Woman. London: Doubleday.

Grumbach, M. M., Hughes, I. A., \& Conte, F. A. (2003). Disorders of Sex Differentiation. In P. Reed Larsen, H. M. Kronenberg, S. Melmed \& K. S. Polonsky (Eds.), Williams Textbook of Endocrinology (10th ed.). Philadelphia, USA: Saunders.

Haire, N. (1937). Introduction. In N. Hoyer (Ed.), Man into Woman: An Authentic Record of a Change of Sex. London, UK: Jarrolds Publishers (London) Limited.

Hale, S. (1991). Feminist Method, Process, and Self-Criticism: Interviewing Sudanese Women. In S. Berger Gluck \& D. Patai (Eds.), Women's Words: The Feminist Practice of Oral History. New York, USA: Routledge.

Hall, L. (2004). Confidentially Speaking: Ethics in Interviewing. In A. Green \& M. Hutching (Eds.), Remembering: Writing oral history. Auckland, NZ: Auckland University Press. 
Hamer, D. H., Hu, S., Magnuson, V. L., Hu, N., \& Pattatucci, A. M (1993). A Linkage between DNA Markers on the X Chromosome and Male Sexual Orientation. Science, 16 July, 261, 321-327. Retrieved from http://postcog.ucd.ie/files/2881563.pdf

Hamilton, B. A., \& Wynshaw-Boris, A. (2004). Basic Genetics and Patterns of Inheritance. In R. K. Creasy, R. Resnik (Eds.) \& J. D. Iams (Assoc. Ed.), Maternal-Fetal Medicine: Principles and Practice (5th ed.). Philadelphia, USA: Saunders.

Harlow, N. (c1977). Dr John Money Interview - Part II. Questions physicians ask about gender identity. Medical Tribune, 23-26.

Harper, C. (2007). Intersex. Oxford, UK; New York, USA: Berg Publishers.

Heywood, L., \& Drake, J. (1997). Introduction. In L Heywood \& J Drake (Eds.), Third wave agenda: being feminist, doing feminism. Minneapolis, USA: University of Minnesota Press.

Hines, S. (2007). TransForming gender: Transgender practices of identity, intimacy and care. Bristol, UK: The Policy Press.

Hirschfeld, M. (1919). The homosexuality of men and women (2nd ed.) (2000 ed. translated by M. A. Lombardi-Nash). Amherst, NY, USA: Prometheus Books.

Hirschfeld, M. (1935). Women east and west: impressions of a sex expert. London, UK: W. Heinemann (Medical books).

History Month (2011). Lili Elbe. Retrieved from http://lgbthistorymonth.org.uk/history/lgbt-people/ biographies/lili-elbe/

Hoby, H. (2010). The Feminine Mystique by Betty Friedan. Retrieved from http://www.guardian.co.uk/ books/2010/apr/11/feminine-mystique-betty-friedan-feminism

Holmes, M. (1995). Queer Cut Bodies: Intersexuality and Homophobia in Medical Practice. Retrieved from http://www.usc.edu/libraries/archives/queerfrontiers/queer/papers/ holmes.long.html

Holmes, M. (1998). In(to)Visibility. In D. Atkins (Ed.), Looking Queer: Body Image and Identity in Lesbian, Bisexual, Gay, and Transgender Communities. Binghamton, NY, USA: Harrington Park Press.

Holmes, M. (2002). Rethinking the Meaning and Management of Intersexuality. Sexualities, 5(2), 159180. Retrieved from http://sex.sagepub.com/content/5/2/159.full.pdf

Hoyer, N. (Ed.) (1937). Man into Woman: An Authentic Record of a Change of Sex (translated from German by H. J. Stenning). London, UK: Jarrolds Publishers (London) Limited.

Hughes, I. A., Houk, C., Ahmed, S. F., \& Lee, P. A. (2006). Consensus statement on management of intersex disorders. Archives of Disease in Childhood, July, 91(7), 554-560.

Human Rights Commission. (2007). "To Be Who I am”: Report of the Inquiry into Discrimination Experienced by Transgender People. Auckland, NZ: Author.

Human Rights Commission (30 July 2010). To Be Who I Am. Retrieved from http://www.hrc.co.nz/ newsletters/to-be-who-i-am/2010/07/have-your-say-2/

Hyde, J. S. (2005). The Gender Similarities Hypothesis. American Psychologist, 60(6), 581-592.

Intersex Society of North America (ISNA). (2006). Handbook for Parents: Consortium on the Management of Disorders of Sex Development. Rohnert Park, CA, USA: Author. 
Intersex Society of North America (ISNA). (2008). MYTH \#6: You can't raise an intersexed child as a boy or a girl without surgery. Retrieved from http://www.isna.org/faq/ten_myths/impossible

Intersex Society of North America (ISNA). (2008). MYTH \#7: ISNA advocates doing nothing and raising intersexed babies in a third gender. Retrieved from http://www.isna.org/faq/ten_myths/ third_gender

Intersex Trust Aotearoa New Zealand (ITANZ). (2011). ITANZ Board Trust Members. Retrieved from http://www.ianz.org.nz/trust\%20members2.html

Jefferson, T. (2009). Crime. In P. Essed, D. T. Goldberg \& A. Kobayashi (Eds.), A Companion to Gender Studies. Chichester, UK: Wiley-Blackwell

Jeffries, S. (2009). Orlan's art of sex and surgery. Retrieved from http://www.guardian.co.uk/ artanddesign/2009/jul/01/orlan-performance-artist-carnal-art

Jones, R. W. (2009). The 1984 Article. In J. Manning (Ed.), The Cartwright papers: essays on the cervical cancer inquiry of 1987-88. Wellington, NZ: Bridget Williams Books Ltd.

Kedgley, S. (1996). Mum's the Word: The Untold Story of Motherhood in New Zealand. Auckland, NZ: Random House New Zealand Ltd.

Keir, J. (Producer \& Director). (2002). Mani’s Story [Television documentary]. New Zealand: Greenstone Pictures.

Kerry, S. C. (2005). Are You A Boy or A Girl? Contesting the Uncontested: Intersex and Genders (Unpublished doctoral thesis, University of Newcastle, Australia). Retrieved from http://nova.newcastle.edu.au/vital/access/manager/Repository/uon:747/ATTACHMENT02?exact=t уре $\% 3 \mathrm{~A} \% 22$ thesis $\% 22 \& \mathrm{f0}=$ subject $\% 3 \mathrm{~A} \% 22$ gender $\% 22$

Kessler, S. J. (1998). Lessons from the Intersexed. New Brunswick, USA: Rutgers University Press.

Kessler, S. J. (2001). The Medical Construction of Gender: Case Management of Intersexed Infants. In M. Wyer, M. Barbercheck, D. Giesman, H. O. Öztürk \& M. Wayne (Eds.), Women, Science and Technology: A Reader in Feminist Science Studies. New York, USA \& London, UK: Routledge.

Kirsch, G. E. (1999). Ethical Dilemmas in Feminist Research: The Politics of Location, Interpretation and Publication. Albany, USA: State University of New York Press.

Kitzinger, C. (1999). Intersexuality: Deconstructing the Sex/Gender Binary. Feminism \& Psychology, 9(4), 493-498.

Klempner, M. (2000). Narrating Life Review Interviews with Survivors of Trauma. In R. Perks \& A. Thomson (Eds.), The Oral History Reader (2nd ed. pub. 2006). London \& New York: Routledge.

Krieger, N. \& Fee, E. (1996). Man-Made Medicine and Women's Health: The Biopolitics of Sex/Gender and Race/Ethnicity (orig. pub. 1994). In K. L. Moss (Ed.), Man-Made Medicine: Women's Health, Public Policy, and Reform. Durham, NC, USA: Duke University Press.

Laurie, A. J. (2004). Speaking the Unspoken: Lesbian Oral Histories in Aotearoa New Zealand. In A. Green \& M. Hutching (Eds.), Remembering: Writing oral history. Auckland, NZ: Auckland University Press.

Laurie, A. J. (2009). The Aotearoa/New Zealand Homosexual Law Reform Campaign. In A. J. Laurie \& L. Evans (Eds.), Twenty Years On: Histories of Homosexual Law Reform in New Zealand. Wellington, NZ: Lesbian \& Gay Archives of New Zealand (LAGANZ).

Liggins Institute. (2010). About the Liggins Institute. Retrieved from http://www.liggins.auckland.ac.nz/ 
Liggins Institute (2010). Professor Sir Graham Liggins. Retrieved from http://www.liggins.auckland.ac.nz/uoa/liggins/people/liggins.cfm

Low, Y., Hutson, J. M., \& Murdoch Children's Research Institute Sex Study Group (2003). Rules for clinical diagnosis in babies born with ambiguous genitalia. Journal of Paediatric Child Health, 39, 406-413.

Lowe, M. (1982). Social Bodies: The Interaction of Culture and Women's Biology. In R. Hubbard, M. S. Henifin \& B. Fried (Eds.), Biological Woman - The Convenient Myth: A Collection of Feminist Essays and a Comprehensive Bibliography. Rochester, VT, USA: Schenkman Books, Inc.

Lyons, R. (1977). Doctor Money speaks, the whole wide world listens. News-Letter, 22 April, 4.

Macdonald, N. (2012). Beauty Reigns. Your Weekend [Dominion Post supplement], 7 April, 8-10.

MacKenzie, D., Huntington, A., \& Gilmour, J. A. (2009). The experiences of people with an intersex condition: a journey from silence to voice. Journal of Clinical Nursing, 18, 1775-1783.

Maguire, P. (2008). Feminist Participatory Research. In A. M. Jaggar (Ed.), Just Methods: An Interdisciplinary Feminist Reader. Boulder, CO, USA: Paradigm Publishers.

Manning, J. (2009). Introduction. In J. Manning (Ed.), The Cartwright papers: essays on the cervical cancer inquiry of 1987-88. Wellington, NZ: Bridget Williams Books Ltd.

Matheson, C. (2009). A Never-ending Story. In J. Manning (Ed.), The Cartwright papers: essays on the cervical cancer inquiry of 1987-88. Wellington, NZ: Bridget Williams Books Ltd.

Matthews, J. J. (1984). Good and Mad Women: The Historical Construction of Femininity in TwentiethCentury Australia. North Sydney, Australia: George Allen \& Unwin Australia Pty Ltd.

Maxson, L. R., \& Daugherty, C. H. (1989). Genetics: A Human Perspective (2nd ed.). Dubuque, IA, USA: Wm C Brown Publishers.

McCarthy, L. (2009). A Girl or a Boy? Information for parents when a baby's gender is uncertain at birth [pamphlet]. Auckland: Leigh McCarthy

McGeough, K. M. (2004). The Romans: An Introduction. Santa Barbara, CA, USA: Oxford University Press.

Mika, C. (2007). Locating the Lisp Gene. In J. Hutchings \& C. Aspin (Eds.), Sexuality and the Stories of Indigenous Peoples. Wellington, NZ: Huia Publishers.

Millett, K. (1971). Sexual Politics (1972 ed.). London, UK: Abacus (Sphere Books Ltd).

Mingin, G., \& Baskin, L. S. (2002). Management of chordee in children and young adults. Urologic Clinics of North America, May 29(2), 277-284.

Ministry of Youth Development. Sex distribution. Retrieved from http://www.youthstats.myd.govt.nz/ demographic/sex-distribution.html

Money, J. (1961). Hermaphroditism. In A. Ellis \& A. Abarbanel (Eds.), The Encyclopaedia of Sexual Behaviour. New York, USA: Hawthorn Books, Inc.

Money, J. (1963). Developmental Differentiation of Femininity and Masculinity Compared. In S. M. Farber \& R. H. L. Wilson (Eds.), Man and Civilisation: The Potential of Woman. New York, USA: McGraw-Hill Book Company.

Money, J. (1968). Sex Errors of the Body: Dilemmas, Education, Counselling. Baltimore, USA: The Johns Hopkins University Press. 
Money, J. (1975). Ablatio Penis: Normal Male Infant Sex-Reassigned as a Girl. Archives of Sexual Behavior, 4(1), 65-71.

Money, J. (1986). Gender Identity and Gender Transposition: Longitudinal Outcome Study of 32 Male Hermaphrodites Assigned as Girls. Journal of Sex \& Marital Therapy, Fall, 12(3), 165-181.

Money, J. (1987). Sin, Sickness, or Status? Homosexual Gender Identity and Psychneuroendocrinology. American Psychologist, 42(4), 384-399.

Money, J., \& Ehrhardt, A. A. (1972). Man \& Woman, Boy \& Girl: The Differentiation and Dimorphism of Gender Identity from Conception to Maturity. Baltimore, USA \& London, UK: The Johns Hopkins University Press.

Money, J., Hampson, J., \& Hampson, J (1955). Hermaphroditism: Recommendations Concerning Assignment of Sex, Change of Sex, and Psychologic Management. Bulletin of the Johns Hopkins Hospital, October, 97(4), 284-300.

Money, J., \& Tucker, P. (1975). Sexual Signatures: On Being a Man or a Woman. Toronto, Canada: Little, Brown and Company.

Morandi, B. (2012). Hirjas [sic] - the Third Gender by Bruno Morandi. Retrieved from http://www.gruppe28.com/en/article/508.html

Morland, I. (2006). Postmodern Intersex. In S. E. Sytsma (Ed.), Ethics and Intersex. Dordrecht, Netherlands: Springer.

Nash, C. J. (2010). Queer Conversations: Old-time Lesbians, Transmen and the Politics of Queer Research. In K. Browne \& C. J. Nash (Eds), Queer Methods and Methodologies: Intersecting Queer Theories and Social Science Research. Farnham, UK: Ashgate Publishing Limited.

Nataf, Z. I. (1996). Lesbians Talk Transgender. London, UK: Scarlet Press.

New Zealand Herald (2006). Beyer to withdraw transgender rights bill. Retrieved from http://www.nzherald.co.nz/politics/news/article.cfm?c_id=280\&objectid=10397580

Odell, W. D. (2001). Endocrinology of Sexual Maturation. In L. J. DeGroot \& J. L. Jameson (Eds.), Endocrinology. Philadephia, USA: W B Saunders Company.

Oxford Concise Medical Dictionary (6th ed.). (2003). Oxford: Oxford University Press.

Oxford English Dictionary, Concise (11th ed.). (2004). Oxford: Oxford University Press.

Paré, A. (1649). The workes [sic] of that famous Chirurgion Ambrose Parey [sic]: Translated out of Latine [sic] and compared with the French by Thomas Johnson. London, UK: printed by Richard Cotes and Willi Du-gard, and are to be sold by John Clarke entering into Mercers Chappell.

Parliament. Human Rights (Gender Identity) Amendment Bill 2004. Retrieved from http://www.parliament.nz/NR/rdonlyres/039FFEDB-697B-4CAE-B09C-1182AA94DA68/ 41002/1168GenderIdentity1.pdf

Passerini-Glazel, G. (1989). New 1-Stage Procedure for Clitorovaginoplasty in Severely Masculinised Female Pseudohermaphrodites. The Journal of Urology, August, 142(2), (pt 2), 565-568.

Passerini-Glazel, G., \& Aragona, F. (1998). Intersex Disorders. In H. N. Whitfield, W. F. Hendry, R. S. Kirby, \& J. W. Duckett (Eds.), Textbook of Genitourinary Surgery (1). Oxford, UK: Blackwell Science. 
Patai, D. (1991). US Academics and Third World Women: Is Ethical Research Possible? In S. Berger Gluck, \& D. Patai (Eds.), Women's Words: The Feminist Practice of Oral History. New York, USA: Routledge.

Paul, C. (2009). The Cervical Cancer Study: science, the profession and the revisionists. In J. Manning (Ed.), The Cartwright papers: essays on the cervical cancer inquiry of 1987-88. Wellington, NZ: Bridget Williams Books Ltd.

Peggy (2011). Surgically Intersexed? Retrieved from http://www.bodieslikeours.org/forums/ showthread.php?t=3246

Peter (2011). Welcome Ruun. Retrieved from http://www.bodieslikeours.org/forums/ showthread.php?t=3246

Pickersgill, K. (Reporter). (1997). A Sexual Dilemma [Television report]. In 20/20. New Zealand: TV3.

Pilkington, E. (2008). Childbirth: Transgender man has his baby, naturally. Retrieved from http://www.guardian.co.uk/world/2008/jul/05/gender.usa

Portelli, A. (1991). The Death of Luigi Trastulli and Other Stories: Form and Meaning in Oral History. Albany, USA: State University of New York Press.

Potts, A. (2002). The Science/Fiction of Sex: Feminist deconstruction and the vocabularies of heterosex. Routledge: London, UK \& New York, USA.

Pullon, S., \& Benn, C. (2008). The New Zealand Pregnancy Book: A guide to pregnancy, birth and a baby's first three months. Wellington, NZ: Bridget Williams Books.

Quigley, C. A., \& Vilain, E. (2010). Genetic Basis of Gonadal and Genital Development. In J. L. Jameson \& L. J. De Groot (Eds), Endocrinology (6th ed., vol. 2). Philadelphia, USA: Saunders.

Quigley, C. A. (2009). Disorders of Sex Development: When To Tell the Patient [PowerPoint presentation]. Retrieved from http://www.accordalliance.org/ images/stories/QuigleyLWPES_PAS_mini_course_may09_for_Accord.pdf

Rainbow Youth. Home page. Retrieved from http://www.rainbowyouth.org.nz/

Rainbow Youth. Queer Youth. Retrieved from http://www.rainbowyouth.org.nz/queer-youth

Rakusen, J. (1981). Depo-Provera: the extent of the problem. A case study in the politics of birth control. In H. Roberts (Ed.), Women, health and reproduction. London, UK; Boston, USA: Routledge \& Kegan Paul Ltd.

Reimer, David (Obituary) (2004). The Telegraph. Retrieved from http://www.telegraph.co.uk/news/ obituaries/1461653/David-Reimer.html

Rich, A. (1978). The Theft of Childbirth. In C. Dreifus (Ed.) Seizing Our Bodies: The Politics of Women's Health. New York, USA: Vintage Books.

Rich, A. (1981). Compulsory Heterosexuality and Lesbian Existence (1980, Signs, 5(4)). London, UK: Onlywomen Press Ltd.

Rogers, L. (2001). Sexing the Brain. New York, USA: Columbia University Press.

Rothblum, E. D., \& Franks, V (1983). Introduction: Warning! Sex-Role Stereotypes May Be Hazadous to Your Health. In V. Franks \& E. D. Rothblum (Eds.), The Stereotyping of Women: Its Effects on Mental Health. New York, USA: Springer Publishing Company, Inc. 
Rutkow, I. M. (2008). History of Surgery. In C. M. Townsend, R. D. Beauchamp, B. M. Evers, \& K. L. Mattox (Eds.), Sabiston Textbook of Surgery: The Biological Basis of Modern Surgical Practice (18th ed.). Philadelphia, USA: Saunders.

Ruun (2011). Being both? Retrieved from http://www.bodieslikeours.org/forums/ showthread.php?t=3246

San Francisco Human Rights Commission (2004). Intersex Hearing (Television report). USA: San Francisco Government Television (SFGTV).

Shanner, L. (2009). Reproduction. In P. Essed, D. T. Goldberg \& A. Kobayashi (Eds.), A Companion to Gender Studies. Chichester, UK: Wiley-Blackwell.

Shields, R. (2010). India's “third sex" win a measure of public acceptance. Retrieved from http://www.independent.co.uk/news/world/asia/indias-third-sex-win-a-measure-of-publicacceptance-1905797.html

Simpson, J. Y. (1871). Anaesthesia, Hospitalism, Hermaphroditism and a proposal to stamp out smallpox and other contagious diseases (W. G. Simpson, Ed.). Edinburgh, UK: Adam and Charles Black.

Skegg, D. C. G. (2009). Foreword. In J. Manning (Ed.), The Cartwright papers: essays on the cervical cancer inquiry of 1987-88. Wellington, NZ: Bridget Williams Books Ltd.

Snyder III, H. M., Retik, A. B., Bauer, S. B., \& Colodny, A. H. (1983). Feminising Genitoplasty: A Synthesis. The Journal of Urology, 129(May), 1024-1026.

Speroff, L. \& Fritz, M. A. (2005). Clinical Gynaecologic Endocrinology and Infertility. Philadelphia, USA: Lippincott Williams \& Wilkins.

Spivak, G. C. (1988). Can the Subaltern Speak? In B. Ashcroft, G. Griffiths \& H. Tiffin (Eds.), The Post-Colonial Studies Reader (pub. 1995). London, UK \& New York, USA: Routledge.

Stanford University (2011, 21 November). Feminist Perspectives on Sex and Gender. Retrieved from http://plato.stanford.edu/entries/feminism-gender/\#BioDet

Statistics New Zealand (2008). Considering Sexual Orientation as a Potential Official Statistic: Discussion paper. Wellington, NZ: Statistics New Zealand. Retrieved from http://www.stats.govt.nz/browse_for_stats/people_and_communities/marriages-civil-unions-anddivorces/considering-sexual-orientation.aspx

Stone, A. (2007). On the Genealogy of Women: A Defence of Anti-Essentialism. In S. Gillis, G. Howie, \& R. Munford (Eds.), Third Wave Feminism: A Critical Exploration (Expanded Second Edition). New York, USA: Palgrave Macmillan.

Swiatecka-Urban, A. \& Devarajan, P. (2004). Denys-Drash Syndrome. Retrieved from www.emedicine.com/PED/topic564.htm

Syme, J. (1842). Principles of Surgery. London. UK: H Baillière.

Te Awekotuku, N. (1991). Mana Wahine Maori: Selected Writings on Maori Women's Art, Culture and Politics. Auckland, NZ: New Women's Press.

Thomas, D. F. M. (2004). Gender assignment: background and current controversies. BJU International, May, 93(3), 47-50.

Thompson, P. (1988). The Voice of the Past: Oral History (2nd ed.). In R. Perks \& A. Thomson (Eds.), The Oral History Reader (2nd ed. pub. 2006). London \& New York: Routledge. 
Viloria, H. (2011). Dispelling the Myths: My Experience Growing Up Intersex and Au Naturel. Retrieved from http://www.bodieslikeours.org/index.php/our-lives/22-hida-new-story

Wall, O. A. (1919). Sex and Sex Worship (Phallic Worship). A Scientific Treatise on Sex, its Nature and Function, and its Influence of Art, Science, Architecture, and Religion - with Special Reference to Sex Worship and Symbolism. St Louis, USA: C V Mosby Company.

Warne, G. L. (1980). Your Child with Congenital Adrenal Hyperplasia. Parkville, Australia: Royal Children's Hospital. Retrieved from http://www.rch.org.au/cah_book

Warne, G. L. (1997). Complete Androgen Insensitivity Syndrome. Parkville, Australia: Royal Children's Hospital. Retrieved from http://www.rch.org.au/publications/CAIS.pdf

Whelehan, I. (1995). Modern Feminist Thought: From the Second Wave to "Post-Feminism”. Edinburgh, UK: Edinburgh University Press Ltd.

Wilson, B. E. (2004). 5-Alpha-Reductase Deficiency. Retrieved from www.emedicine.com/PED/ topic1980.htm

Wittig, M. (1992). The Straight Mind and Other Essays. Boston, USA: Beacon Press.

Young, H. (1937). Genital Abnormalities, Hermaphroditism and Related Adrenal Diseases. Baltimore, USA: The Williams \& Wilkins Company.

Young, H. (1940). A Surgeon's Autobiography. New York, USA: Harcourt, Brace and Company.

Yucel, S., Sanli, A, Kukul, E., Karaguzel, G., Melikoglu, M., \& Guntekin, E. (2006). Midline Dorsal Plication to Repair Recurrent Chordee at Reoperation for Hypospadias Surgery Complication. The Journal of Urology, 175(February), 699-703. 